\title{
DISTRIBUIÇÃO E ATRIBUTOS DOS SOLOS EM RELAÇÃO À FORMA E EVOLUÇÃO DE UMA VERTENTE EM MONTE ALTO, SP
}

\author{
JOSÉ MARQUES JÚNIOR \\ Engenheiro Agrônomo
}

Orientador: Prof. Dr. IGO FERNANDO LEPSCH

Tese apresentada à Escola Superior de Agricultura "Luiz de Queiroz", da Universidade de São Paulo, para obtenção do título de Doutor em Agronomia, Área de concentração: Solos e Nutrição de Plantas.

\author{
PIR A C I C A B A
}

Estado de São Paulo - Brasil

Outubro - 1995 
Dadoe internacionsis de Catalogą̧⿸丆口 na Publ icaçäo (ClP) DIVISAD DE BIBLJOTECA E DOCUMENTACÁO - CempUS "LU/z de QUEITOZ"JUSP

Marques Júnior, José

Distribulça e atributos dos solos em relaçăo à forma e evoluça de uma vertente em Monte Alto, SP. Piracicaba, 1995.

$226 p$.

Te8e - ESALQ

Bibliografia.

1. Solo de vertente - Propriedade ff́sico-auímica - Monte Alto 2. Geomorfologia - Monte Alto I. Escola Superior de Agricultura Luiz de Queiroz, Piracicaba

$\operatorname{CDD} \quad 631.4$ 


\title{
DISTRIBUIÇÃO E ATRIBUTOS DOS SOLOS EM RELAÇÃO À FORMA E EVOLUÇÃO DE UMA VERTENTE EM MONTE ALTO, SP
}

\author{
JOSÉ MARQUES JÚNIOR
}

Aprovada em: 12/12/1995

Comissão julgadora:

Prof. Dr. Igo Fernando Lepsch

ESALQ/USP

Prof. Dr. Celso Augusto Clemente ESALQ/USP

Prof. Dr. Pablo Vidal Torrado ESALQ/USP

Prof. Dr. Nilton Curi

UFLA

Prof. Dr. José Frederico Centurion

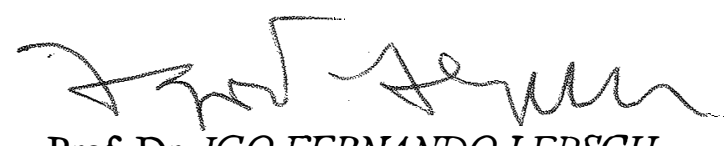

Prof. Dr. IGO FERNANDO LEPSCH

Orientador 


\section{À DEUS ,}

Aos meus pais

BENEDITA E JOSÉ (em memória)

DEDICO

À AUXILIADORA

OFERE CQ O 
Ao amigo Adauto (em memória)

Que fez da convicção em seus sonhos um extremo compromisso. 


\section{AGRADECIMENTOS}

Ao Prof. Dr. Igo F. Lepsch pela eficiência na orientação deste trabalho, e por seu posicionamento ético que muito inspira minha carreira.

À FCAV/UNESP - Campus de Jaboticabal, à ESALQ/USP, e a CAPES/PICD, pela oportunidade proporcionada para realização do curso de Doutorado.

À FAPESP pelo auxílio financeiro oferecido.

Aos membros da banca examinadora: Prof. Dr. Igo F. Lepsch, Prof. Dr. Pablo Vidal Torrado, Prof. Dr. Celso A Clemente, Prof. Dr. Nilton Curi e Prof. Dr. José Frederico Centurion, pelas críticas e sugestões ao trabalho.

Ao Prof. Dr. Gener Tadeu Pereira e ao Prof. Dr. Antônio Sérgio Ferraudo, do Departamento de Ciências Exatas da FCAV/UNESP pelo prestimoso auxílio na realização das análises estatísticas.

Ao Prof. Dr. Luiz Roberto Lopes, Prof. Dr. Claudine Amaral, Prof. Dr. Walter Politano do Departamento de Engenharia Rural da FCAV/UNESP pela ajuda no levantamento do perfil altimétrico e mapeamento da área.

Ao funcionário Ronaldo pelo auxílio nos trabalhos de campo e Izilda pela confecção dos difratogramas de raios X e termogramas do Departamento de Engenharia Rural da FCAV/UNESP.

Aos funcionários do Departamento de Solos e Adubos da FCAV/UNESP que com dedicação colaboraram para a realização deste trabalho. Adauto e Marcelo nos trabalhos de campo, Maria Inês, Ademir e Hoster nos trabalhos de laboratório, Alessandra, Célia e Mônica nos trabalhos de digitação.

À Alessandra pelo empenho no serviço de digitação.

Aos funcionários da UAD (Unidade de Auxílio Didático) da FCAV/UNESP: Patrícia, Graça e Reovaldo pela colaboração e sugestões na montagem do trabalho.

Aos acadêmicos estagiários Gláucia, Sérgio e Moisés pela ajuda na coleta das amostras. 
À Divisão de Geologia do Instituto de Pesquisas Tecnológicas de São Paulo (DIGEO-IPT) pela realização das fotografias das lâminas de micromorfologia do solo.

Ao Nilton Curi pela realização da análise térmica diferencial e pela amizade e incentivo à minha carreira em todos esses anos.

Ao Pablo pela prestimosa ajuda na interpretação das lâminas de micromorfologia.

Ao Dr. Wanderley Tremocoldi da Seção de Pedologia do IAC, e a Elizabeth do laboratório de mineralogia da ESALQ/USP, pelo auxílio nas análises mineralógicas.

Ao Gener pela amizade, pelo companheirismo e incentivo.

Aos amigos Marćlio, Corá e Célia pelo incentivo, colaboração e ótima convivência em todos estes anos. 


\section{ÍNDICE}

Página

LISTA DE FIGURAS $\mathrm{xi}$

LISTA DE QUADROS xvi

RESUMO

SUMMARY

1. INTRODUÇÃO

2. REVISÃO BIBLIOGRÁFICA . 03

2.1. Geologia Regional 03

2.1.1. O grupo Bauru - aspectos da litoestratigrafia 03

2.1.2. O cretáceo na região de Monte Alto 05

2.1.3. A paleogeografia 07

2.1.4. Implicações tectônicas regionais 09

2.2. Depósitos cenozóicos 09

2.3. Geomorfologia 12

2.4. Solos 14

2.4.1. Os estudos de solo-geomorfologia 14

2.4.2. Gênese dos latossolos 19

2.4.3. Gênese de solos com B textural 21

2.4.4. Variabilidade do solo 23

2.4.5. Implicações da variabilidade na taxonomia e cartografia do solo .. $\quad 25$

2.5. A transeção como método de estudos de solos ........................................ 26

2.6. Testes estatísticos para aferição da variabilidade espacial ........................ 27 


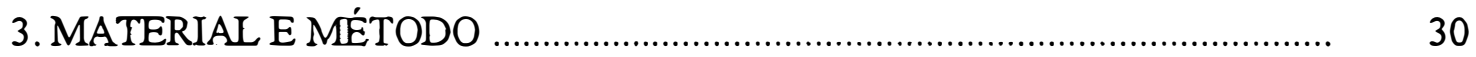

3.1. Localização e caracterização do meio fisico ................................................. 30

3.2. Geologia, geomorfologia e solos .............................................................. 30

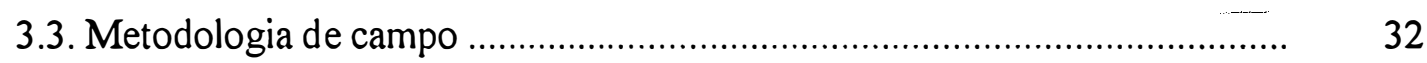

3.3.1. Escolha da área à partir de uma transeção ......................................... 32

3.3.2. Caracterização da área ................................................................... 33

3.4. Metodologia de laboratório ………………........................................... 35

3.4.1. Caracterização fisica ......................................................................... 35

3.4.2. Caracterização química ................................................................ $\quad 35$

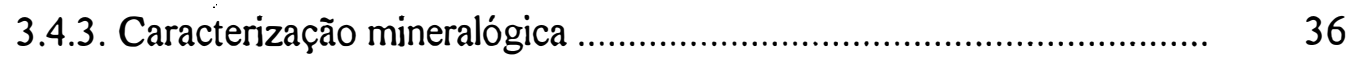

3.4.4. Caracterização micromorfológica ................................................. 36

3.5. Análises estatísticas dos resultados .......................................................... 37

3.5.1. Análise estatística dos dados granulométricos ................................... 37

3.5.2. Análise estatística dos parâmetros químicos e fisicos dos solos nas superficies geomórficas ................................................................. 37

3.5.3. Análise multivariada dos dados da transeção ..................................... 37

3.5.4. Análise de locação estatística pelo "split moving windows" ............. 38

3.5.5. Avaliação indireta da erodibilidade dos solos ..................................... 38

4. RESULTADOS E DISCUSSÃO _............................................................... 39

4.1. Fisiografia - superficies geomórficas e elementos de encosta ....................... 39

4.1.1. Visão geral da área e classes de declive ................................................ 39

4.1.2. Superficies geomórficas e segmentos de vertente .............................. 42

4.1.3. Ocorrência dos depósitos superficiais ................................................ 45

4.2. Solos da Área de estudo ........................................................................... 52

4.2.1. Avaliação das propriedades químicas e fisicas das unidades de mapeamento ........................................................................ 52

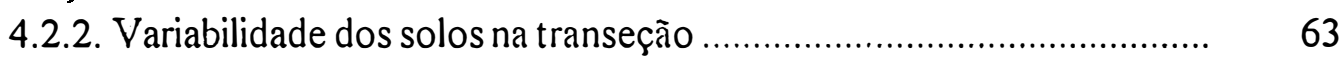

4.2.3. Avaliação da micromorfologia dos solos .......................................... $\quad 74$ 
4.2.4. Avaliação qualitativa e quantitativa da mineralogia da fração argila desferrificada. 83

4.2.5. Formas de ferro extraído com ditionito e oxalato ...................................... 86

4.3. Avaliação estatística da granulometria das areias .............................................. 90

4.4. Análises de agrupamento das propriedades químicas e fisicas nos pontos da

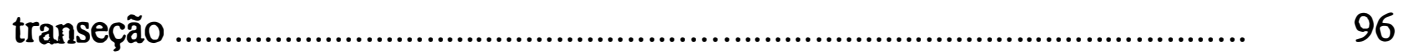

4.5. Locação estatística dos limites dos solos ........................................................... 106

4.6. Modelo da gênese e evolução dos solos na paisagem ....................................... 119

4.6.1. Gênese dos latossolos da área ....................................................... 120

4.6.2. Gênese dos podzólicos ................................................................... 123

4.6.3. Gênese dos solos menos desenvolvidos .......................................... 125

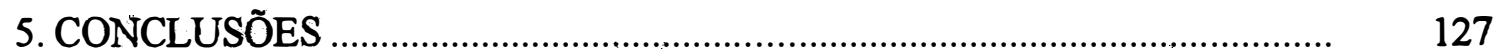

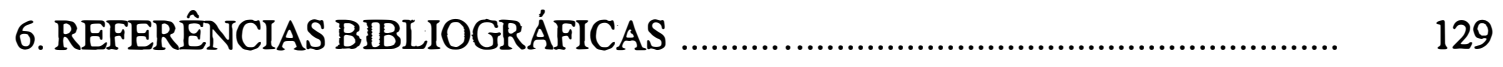

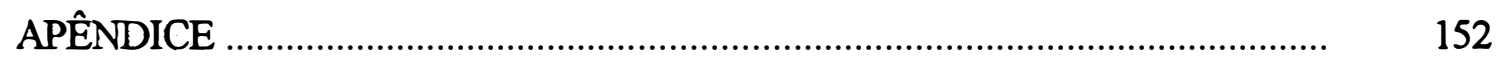




\section{LISTA DE FIGURAS}

Página

1. Distribuição do grupo Bauru no Estado de São Paulo........................................ 04

2. Mapa geológico da serra do Jaboticabal, região de Monte Alto ....................... 06

3. Fatores paleoambientais e paleoclimáticos è subdivisão estratigráfica do grupo Bauru.

4. Provável modelo extensional de falhamentos associado às intrusivas de Jaboticabal, em Monte Alto-SP

5. Segmentos da vertente. Em primeiro plano o modelo de WOOD (1942), e em segundo plano o modelo RUHE (1975)

6. Modelos das nove unidades hipotéticas da vertente DALRYMPLE et al. (1968)

7. Localização da área de estudo no Planalto Ocidental

8. Mapa de localização da área de estudo

9. Classes de declive da área em estudo

10. Superficies geomórficas e seus compartimentos dentro da área em estudo

11. Histograma da distribuição de partículas em cinco classes granulométricas de areia, em quatro profundidades selecionadas, cla primeira amostragem profunda

12. Histograma da distribuição de partículas em cinco classes granulométricas de areia, em quatro profundidades selecionadas, da segunda amostragem profunda.

13. Histograma da distribuição de partículas em cinco classes granulométricas de areia, em quatro profundidades selecionadas, da terceira amostragem profunda

14. Modelo da evolução inicial da paisagem com origem nos eventos neo-tectônicos

15. Mapa de solos semi-detalhado da área em estudo

16. Médias (quadrado pequenos) com respectivos intervalos de confiança (médiat $\mathrm{Sx}$. e média $\pm 1,96 \mathrm{Sx}$ ) do $\mathrm{pH}$ em $\mathrm{H}_{2} \mathrm{O}$ e $\mathrm{KCl}$ das unidades de mapeamento.

17. Médias (quadrado pequenos) com respectivos intervalos de confiança (médiat Sx e média $\pm 1,96 \mathrm{~S} x)$ da acidez trocável e $\Delta \mathrm{pH}$ das unidades de mapeamento..... 
18. Médias (quadrado pequenos) com respectivos intervalos de confiança (médiat Sx e média $\pm 1,96 \mathrm{Sx}$ ) da soma de bases e CTC da argila das unidades de mapeamento.

19. Médias (quadrado pequeno) com respectivos intervalos de confiança (médiat Sx e méd a $1,96 \mathrm{Sx}$ ) da saturação por bases e $\mathrm{pH}$ em $\mathrm{CaCl}_{2}$ das unidades de mapeamento

20. Médias (quadrado pequeno) com respectivos intervalos de confiança (médiat $\mathrm{S} x$ e média $\pm 1,96 \mathrm{Sx}$ ) do carbono orgânico e relação areia fina/areia grossa das unidades de mapeamento

21. Médias (quadrado pequeno) com respectivos intervalos de confiança (médiat Sx e média $\pm 1,96 \mathrm{~S} z$ ) da relação silte/argila e argila das unidades de mapeamento

22. Perfil topográfico da transeção na área em estudo, superficies geomórficas, segmentos de vertente e unidades de mapeamento de solos

23. Comportamento de atributos do solo, em duas profundidades, ao longo da transeção de acordo com superficies geomórficas (números romanos) e seus segmentos de vertente: a) saturação por bases; b) $\mathrm{pH}$ em $\mathrm{CaCl}_{2}$

24. Comportamento de atributos do solo, em duas profundidades, ao longo da transeção de acordo com superficies geomórficas (números romanos)' e seus segmentos de vertente: a) Comportamento da CTC da argila na transeção; b) Comportamento da matéria orgânica na transeção.

25. Comportamento de atributos do solo, em duas profundidades, ao longo da transeção de acordo com superficies geomórficas (números romanos) e seus segmentos de vertente: a) Comportamento da soma de bases na transeção; b) Comportamento da relação argila b/argila a na transeção

26. Comportamento de atributos do solo, em duas profundidades, ao longo da transeção de acordo com superficies geomórficas (números romanos) e seus segmentos de vertente: a) Comportamento da relação silte/argila na transeção; b) Comportamento da relação areia fina/areiagrossa na transeção 
27. Perfil 1, horizonte $\mathrm{Bw}_{2}(80-128 \mathrm{~cm})$, microagregado biológico, trama gefúrica com plasma isótico. Fotomicrografia sob luz polarizada em um plano (a) e com nicóis cruzados (b)

28. Perfil 3, horizonte $\mathrm{Bt}_{2}(100-165 \mathrm{~cm})$, trama quitônica localmente gefúrica, plasma isótico. Presença de ferriargilã, fotomicrografia sob luz polarizada em um plano (a) e com nicóis cruzados (b)

29. Perfil 4, horizonte $\mathrm{Bt}_{1}(65-104 \mathrm{~cm})$, plasma isótico localmente vossépico, cutãs de argiluviação. Fotomicrografia sob luz polarizada em um plano (a) e com nicóis cruzados (b).

30. Perfil 4, horizonte $\mathrm{Bt}_{1}(65-104 \mathrm{~cm})$, plasma isótico localmente vossépico, cutãs de argiluviação. Fotomicrografia sob luz polarizada com ampliação $150 x$ (a) e com nicóis cruzados (b)

31. Perfil 5, horizonte E $(28-65 \mathrm{~cm})$, plasma isótico faixas de argiluviação obstruindo porosidade; coalescência de cavidade com contorno mamelonar, revestido por ferrãs. Fotomicrografia sob luz polarizada com ampliação 150x (a) e com nicóis cruzados (b)

32. Perfil 5 , horizonte $\mathrm{Bt}_{1}(61-100 \mathrm{~cm})$, plasma massépico, ferrãs em torno de cavidades e ferriargilãs e argiluviação. Fotomicrografia de luz polarizada em um plano (a) e (b)

33. a) Teor de Fe extraído pelo ditionito-citrato-bicarbonato de sódio (Fed) da fração argila dos latossolos; b) Teor de Fe extraído pelo ditionito-citratobicarbonato de sódio (Fed) da fração argila dos podzólicos

34. Comportamento de atributos dos solos, em duas profundidades, ao longo da transeção de acordo com superficies geomórficas (números romanos) e seus segmentos de vertente a) Desvio padrão e b) Assimetria da distribuição granulométrica das areias nas profundidades de $0-20$ e $60-80 \mathrm{~cm}$

35. Comportamento de atributos dos solos, em duas profundidades, ao longo da transeção de acordo com superficies geomórficas (números romanos) e seus segmentos de vertente a) Média e b) Curtose da distribuição granulométrica das areias nas profundidades de $0-20$ e $60-80 \mathrm{~cm}$. 
36. Dendrograma da análise de Cluster dos parâmetros quimicos e fisicos da transeção estudada na profundidade de $0-20 \mathrm{~cm}$

37. Dendrograma da análise de Cluster dos parâmetros químicos e fisicos da transeção estudada na profundidade de $60-80 \mathrm{~cm}$

38. Distribuição da argila em profundidades nos perfis

39. Resultados do "split moving windows" para cálcio e magnésio na camada 60$80 \mathrm{~cm}$ dos solos em relação as superficies geomórficas (I, II e III) e segmentos de vertente (A, B, C, D e E) ao longo da transeção

40. Resultado do "split moving windows" para $\mathrm{pH} \mathrm{CaCl}_{2}$ e V\% na camada 60$80 \mathrm{~cm}$ dos solos em relação as superficies geomórficas (I, II e III) e segmentos de vertente (A, B, C, D e E) ao longo da transeção

41. Resultado do "split moving windows" para a CTC da argila e areia fina/areia grossa na camada $0-20 \mathrm{~cm}$ dos solos em relação as superficies geomórficas (I, II e III) e segmentos de vertente (A, B, C, D e E) ao longo da transeção.

42. Resultado do "split moving windows" para os valores de cotas e relação silte/ argila do perfil altimétrico na camada $0-20 \mathrm{~cm}$ dos solos em relação as superficies geomórficas (I, II e III) e segmentos de vertente (A, B, C, D e E) ao longo da transeção

43. Médias (quadrado pequeno) com respectivos intervalos de confiança (médiat Sx e média $\pm 1,96 \mathrm{Sx}$ ) das propriedades quimicas dos solos de ocorrência nas superficies geomórficas

44. Médias (quadrado pequeno) com respectivos intervalos de confiança (média \pm Sx e média $\pm 1,96 \mathrm{Sx}$ ) das propriedades químicas dos solos de ocorrência nos segmentos de vertente

45. Médias (quadrado pequeno) com respectivos intervalos de confiança (médiat Sx e média $\pm 1,96 \mathrm{Sx}$ ) das propriedades fisicas de solos de ocorrência nos segmentos de vertente e superficies geomórficas

46. Modelo hipotético de evolução da paisagem com base nos eventos neotectônicos e episódios relacionados com fàses de morfogênese em climas semi-áridos pretéritos $(\mathrm{Km}=$ Formação $)$ Marilia, $\mathrm{Ka}=$ Formação Adamantina; 
a, b e c $=$ Diferentes épocas de ocorrência dos eventos) 


\section{LISTA DE QUADROS}

Página

1. Freqüência de ocorrência e área das classes de declive

2. Freqüência de ocorrência e área das superficies geomórficas e segmento de vertente

3. Freqüência de ocorrência e áreas das unidades de mapeamento de solos

4. Superficies geomórficas, segmentos de vertente e solos de ocorrência

5. Teores de caulinita e gibbsita na fração argila desferrificada e taxa de caulinita/ caulinita+gibbsita dos horizontes $\mathrm{A}$ e $\mathrm{B}$ dos solos estudados.

6. Formas de Fe e CTC da argila dos solos estudados

7. Erodibilidade calculada dos solos da vertente (médias dos pontos da transeção)

8. Grupos formados pela análise de Cluster (parâmetros químicos e fisicos de $0-20$ e $60-80 \mathrm{~cm})$, unidades de mapeamento e porcentagem dos pontos correspondentes.

APÊNDICE 1. Estereograma da área em estudo

APÊNDICE 2. Descrição dos perfis dos solos estudados

APÊNDICE 3. Resultados de análises estatísticas das propriedades químicas e fisicas dos solos e das superficies geomórficas mapeadas na área ......

APÊNDICE 4. Descrição sumária da micromorfologia dos solos estudados

APÊNDICE 5. Difratogramas de raios $X$ representativos da fração argila tratada com DCB (lâminas orientadas) dos solos estudados, e termogramas representativos da fração argila desferrificada 
APÊNDICE 6. Características químicas do depósito neocenozóico obtidas por amostragem profunda

APÊNDICE 7. Capacidade de troca de cátions da argila dos perfis de solos estudados, pelo método gráfico 


\title{
DISTRIBUIÇÃO E ATRIBUTOS DOS SOLOS EM RELAÇÃO \\ À FORMA E EVOLUÇÃO DE UMA VERTENTE \\ EM MONTE ALTO, SP
}

\author{
AUTOR: José Marques Júnior \\ ORIENTADOR: DR. Igo Fernando Lepsch
}

\section{RESUMO}

Com o objetivo de compreender o comportamento dos atributos do solo e ó seu padrão de distribuição na paisagem, estudou-se as relações entre a evolução de uma vertente e suas influências em propriedades básicas do solo, em uma área de domínio dos arenitos do Grupo Bauru em Monte Alto, SP.

Escolheu-se uma área de 612 ha, onde o topo representa a cota regional mais elevada (763 m de altitude). Uma transeção de $2.700 \mathrm{~m}$ de extensão foi locada, seguindo aproximadamente o espigão de uma vertente no sentido das cotas mais baixas (600 m de altitude). Amostragens foram feitas com o trado a intervalos regulares de $25 \mathrm{~m}$ em duas profundidades (0-20 e 60-80 $\mathrm{cm}$ ), e outras amostras ao acaso foram coletadas em torno da transeção após terem sido sorteados. Solos foram também descritos e amostrados em sete trincheiras.

Mapeou-se as superficies geomórficas, elementos da vertente, solos e depósitos superficiais. Sedimentos neocenozóicos foram identificados, e sua origem foi relacionada à ocorrência de movimentos neotectônicos.

Três superficies geomórficas em cronossequência (I>II>III) e sete elementos da encosta foram identificados e relacionados com a ocorrência dos solos, através da sua avaliação de propriedades químicas, fisicas, mineralógicas e micromorfológicas, usando-se testes de comparação de médias. Assim, latossolos ocorrem na superficie I e início da superficie II, solos podzólicos na maior parte da superficie II, e solos pouco desenvolvidos na superficie III. 
Através da análise de "cluster" comprovou-se que a compartimentação da vertente e o estudo das relações dos seus elementos, é importante para entender a ocorrência dos solos e seus processos com maior grau de detalhe. A superficie II e III foram compartimentadas em segmentos que possibilitaram visualizar processos como a transição lateral $\mathrm{Bw}-\mathrm{Bt}$, através do adensamento dos microagregados latossólicos seguido de ação mecânica do fluxo lateral de água, e posterior argiluviação e degradação de argilas, completando a transformação do Bw para Bt.

A indicação dos limites laterais com precisão, através da locação estatística pelo "split moving windows", enfatiza a eficiência complementar dos estudos envolvendo elementos de vertente para os trabalhos de campo nos mapeamentos de solos. Os, limites laterais entre latossolos e latossolos podzólicos, e entre estes e os podzólicos, foram corroborados pelos testes estatísticos. Estes resultados apresentaram boa correlação com os limites observados através da morfologia dos solos no campo.

A ocorrência dos eventos neotectônicos na região conjuntamente com os episódios relacionados com fases de morfogênese em clima semiáridos pretéritos, nortearam o estudo da forma e evolução da vertente, bem como possibilitaram o entendimento da ocorrência de latossolos e solos podzólicos desenvolvidos dos depósitos neocenozóicos, presentes nas cotas mais elevadas. 


\title{
DISTRIBUTION AND ATTRIBUTES OF SOIL IN RELATION \\ TO THE SHAPE AND EVOLUTION OF A VERTENTE \\ IN MONTE ALTO-SP
}

\author{
AUTHOR: José Marques Júnior \\ ADVISER: Dr. Igo Fernando Lepsch
}

\section{SUMMARY}

With the objective of understanding the relationships of soils attributes and their landscape distribution pattern, a slope was studied in a area of sandstone domain of the Bauru Group in Monte Alto, SP.

An area of 612 ha was choosen, where the top represents regional positions (763 $\mathrm{m}$ high). A transect was stablished $(2,700 \mathrm{~m})$ following the crest of a slope downwards to the lowest positions $(600 \mathrm{~m}$ high). Soil samples were taken with an auger at regular intervals of $25 \mathrm{~m}$ out from two depths, $0-20 \mathrm{~cm}$ and $60-80 \mathrm{~cm}$. Other soil samples were collected at randon around the transect. Seven soil pits were also described and sampled.

The geomorphic surfaces, slope elements and soils were mapped out. Surface neocenozoic deposits were identified and their origin was referred to the presence of neo-tectonics.

Three geomorphic surfaces according to a cronosequence (I>II $>$ III) and seven slope elements were identified. Their relations to the soil occurence was tested through chemical, physical, mineralogical and micromorphological analysis. These were confirmed through the means comparision tests. So, the latosols (oxisols) occur on surface I and on the onset of surface II, the red-yellow podzolic (alfisol) on surface II, and most of the poor developed soils on surface III.

Through the "cluster" analyses it was confirmed that the compartimentation of the slope and the study of the relation of its elements is important for the understanding of the soil occurrence and its processes at a high detailled level. Surface II and III were compartmented into segments which made it possible to visualize the processes such as the 
Bw-Bt transition, through the latosol (oxisol) agregate coalescence following by a mechanical action of subsurface water flows, and further lessivage and clay degradation, though completing the $\mathrm{Bw}$ transformation into $\mathrm{Bt}$.

The precise recognition of side limits through the statistical location by the "split moving windows" method, agree with the complementary efficiency of slope elements to field work on soil mapping. The side limits between latosol (oxisols) and latosol-podzolic intergrades (ultisols), and between these and the podzolic ones (alfisols), were clearly identified by the statistic tests. These results presented a good correlation with the observed limits observed through the soil morphology in the field.

The occurrence of neo-tectonic events in the region, together with the episodes related to the morphogenesis phases in ancient semi-arid climate, directed the study of shape and evolution of the slope, as well as making possible the understanding of latosol (oxisol) and podzolic (alfisol) occurrence, developed in the same neo-cenozoic deposit, which was present in the highest landscape positions. 


\section{INTRODUÇÃO}

Os solos situam-se como um dos principais recursos naturais, cujo conhecimento é de grande importância como subsídio básico para apoiar o planejamento racional do uso da terra, entendendo-se este como aquele que coloca a disposição do homem os recursos naturais para o seu melhor uso e beneficio, ao mesmo tempo que preserva estes beneficios para as gerações futuras, FAO (1976).

A interpretação e a transferência de conhecimentos, para o uso agrícola são possíveis, para uma região, a partir de estudos de solos, sendo vistos como corpos naturais, e contínuos na paisagem, com base nas suas relações com a geomorfologia, estratigrafia e hidrologia. Sempre haverá necessidade de se saber ao nível de campo até onde se pode wansferir determinadas informações (generalizações) e, nesse contexto, o estudo das relações solo-paisagem são muito úteis (DANIELS \& HAMMER, 1992).

A área compreendida pelas Cuestas Basálticas e Planalto Ocidental Paulista, enquadrados na Bacia do Paraná, possui estratigrafia, superficies geomórficas e características de vertente peculiares, que influenciam sobremaneira a distribuição dos solos, a qual não é ao acaso, havendo, via de regra, uma ocorrência lógica.

A região de Monte Alto onde se insere o Planalto Ocidental Paulista, com altitude em torno de $900 \mathrm{~m}$, na periferia, até $300 \mathrm{~m}$, no rio Paraná, possui como um dos principais solos de ocorrência os podzólicos vermelho-amarelos, anteriormente referidos como solos podzolizados variação Lins e Marília, registrados no Planalto Ocidental Paulista no final da década de 50, cujos materiais de origem são os arenitos do grupo Bauru (BRASIL, 1960). A vinte quilômetros dali, no sentido leste da região, já no Município de Jaboticabal (transicional com as Cuestas Basálticas), evidencia-se a ocorrência dos solos originados dos produtos de alteração do basalto (Formação Serra Geral). Há também registros da ocorrência 
de intrusivas alcalinas (MANZINI, 1990), o que provavelmente influenciou propriedades diferenciais nos solos, bem como suas relações com a paisagem regional.

Assim sendo, a região apresenta um quadro bastante propício para o estudo das relações solo-paisagem, visando entender a ocorrência e distribuição dos solos para fins cartográficos e taxonômicos gerais. O objetivo deste trabalho foi o de elucidar as principais relações das superficies geomórficas, e seus elementos de encosta, com a distribuição e propriedades dos solos, visando conhecer sua distribuição, para facilitar a previsão de sua ocorrência, elementos básicos para a transferência de conhecimentos para condições similares. 


\section{REVISÃO DE LITERATURA}

\subsection{Geologia regional}

\subsubsection{O grupo Bauru - aspectos da litoestratigrafia}

O Grupo Bauru representa o evento de sedimentação cretácea superior na bacia do rio Paraná, constituindo uma sedimentação de caráter continental. Em São Paulo, os sedimentos desse grupo ocupam quase a metade da superficie do Estado, assentando-se, predominantemente sobre basaltos da Formação Serra Geral que são rochas do grupo São Bento em visível discordância erosiva (FIGURA 1). A visão estratigráfica recente revela que o substrato do grupo foi intensamente falhado em intervalo de tempo correspondendo ao cretáceo médio, destacando-se, algumas estruturas de grande porte como a de Vera CruzMarilia, Alto de Piratininga e as fóssas tectônicas onde se concentra a sedimentação da formação Caiuá (FÚLFARO \& BARCELOS, 1991).

Segundo MANZINI (1990), até o início da década de setenta, havia um consenso entre os principais autores, sobre a ausência de características tectônicas no grupo Bauŕ, no Estado de São Paulo. Esta visão começou a ser mudada por SUGUIO (1973), estudando a então formação Bauru que aflora em Agudos (SP), e posteriormente FÚlfFARO et al. (1983) encontrou intensos falhamentos na região de Piratininga (SP). Outras informações importantes sobre a atuação de processos tectônicos associados à sedimentação do Bauru, são encontradas nos trabalhos de FÚlFARO et al. (1982), ARID et al. (1983), SAAD (1988), e HASUI et al. (1989). 


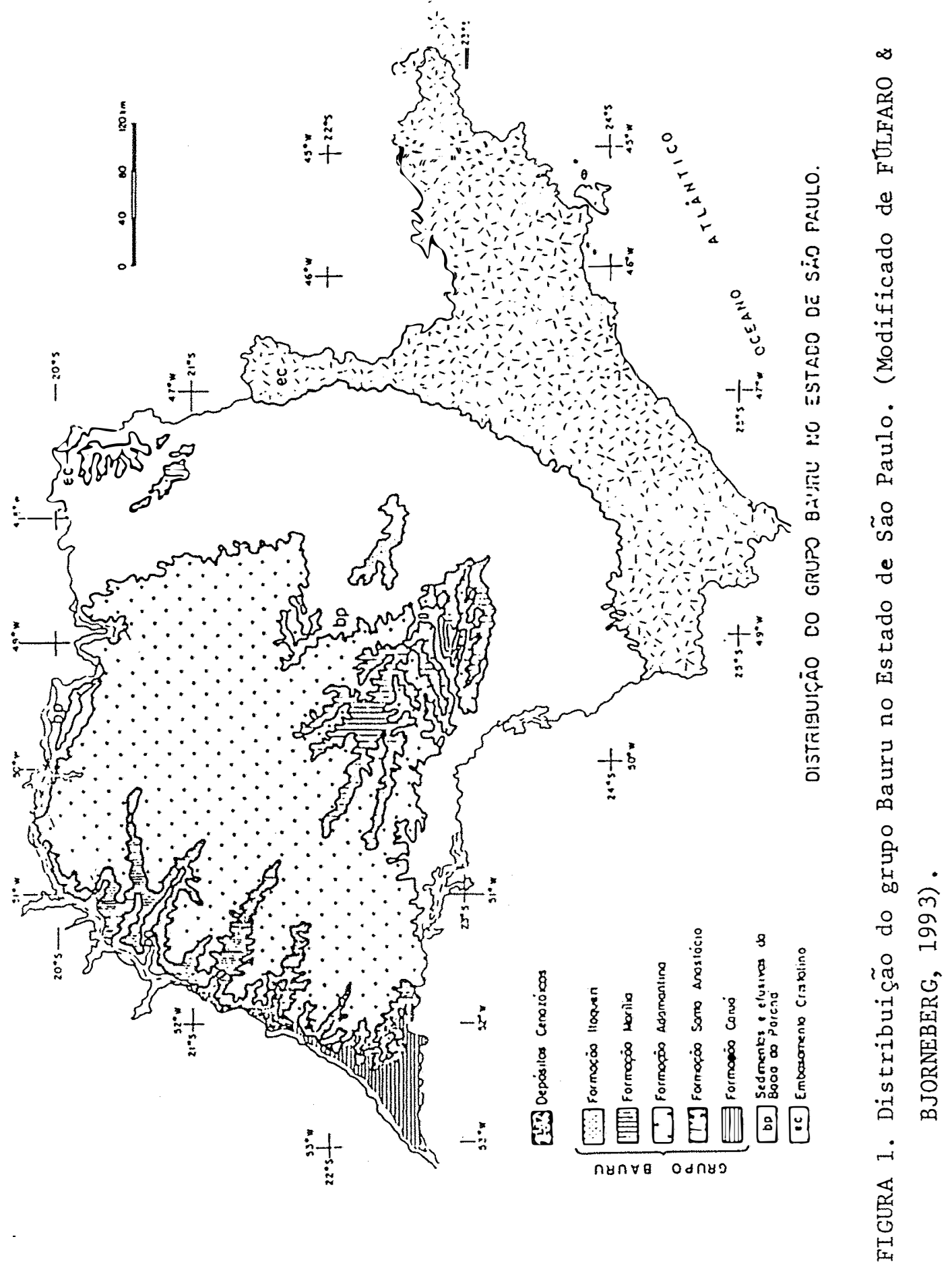


SOARES et al. (1980) apresentam a seqüência estratigráfica mais aceita atualmente, com as formações Caiuá, Santo Anastácio, Adamantina e Marília. BARCELOS et al. (1983), propos a formação Itaqueri como unidade mais recente do grupo.

\subsubsection{O cretáceo na região de Monte Alto (SP)}

O cretáceo na região de Monte Alto (SP) apresenta características paleogeográficas e tectono-sedimentares peculiares, condicionado pela ampla variabilidade litológica (FIGURA 2).

MANZINI (1990), em estudo com elevado nivel de detalhe regional, apresenta as formações Adamantina e Marília, ambas de origem clástica, como as unidades litoestratigráficas na coluna do grupo Bauru, distintas e dominantes na região. A formação Adamantina apresenta arenitos finos a médios, maciços, pouco carbonáticos e com pelotas de argila ("clay-balls"), de ocorrência restrita. A formação Marilia é constituída por arenitos finos a médios, carbonáticos, maciços, com freqüência abundante de arenitos conglomeráticos, com acúmulo de seixos de nódulos carbonáticos e, subordinadamente, camadas de fluxo de lama ("mud-flow"). A maior espessura de perfil sedimentar registrado na literatura, foi de 87 metros. Essas características da formação Marilia se aproximam mais da primeira descrição da mesma feita por SOARES et al. (1980).

Essa descrição está muito próxima daquelas estudadas em outras áreas com as mesmas formações. ALMEIDA et al. (1980) consideram que a textura dos sedimentos é no geral mais fina, nas áreas do espigão norte do Estado. Para CARVALHO (1976), os arenitos desse Grupo apresentam em sua granulometria dominância de fração arenosa com classes mais freqüentes nos intervalos de $0,250-0,125 \mathrm{~mm}$ e $0,125-0,062 \mathrm{~mm}$, podendo ser classificados então como arenitos finos e muitos finos, em geral pobremente selecionados, embora SOARES et al. (1980), a tenham definido como uma unidade composta por arenitos variando de grosseiros a conglomeráticos e mal selecionados. A formação Adamantina apresenta sedimentos finos bem selecionados de maneira mais constante em suas áreas de ocorrência (ALMEIDA et al., 1980), e a formação Marilia, com maior variação, é constituída de areitos finos e grosseiros (SUGUIO 1980). 

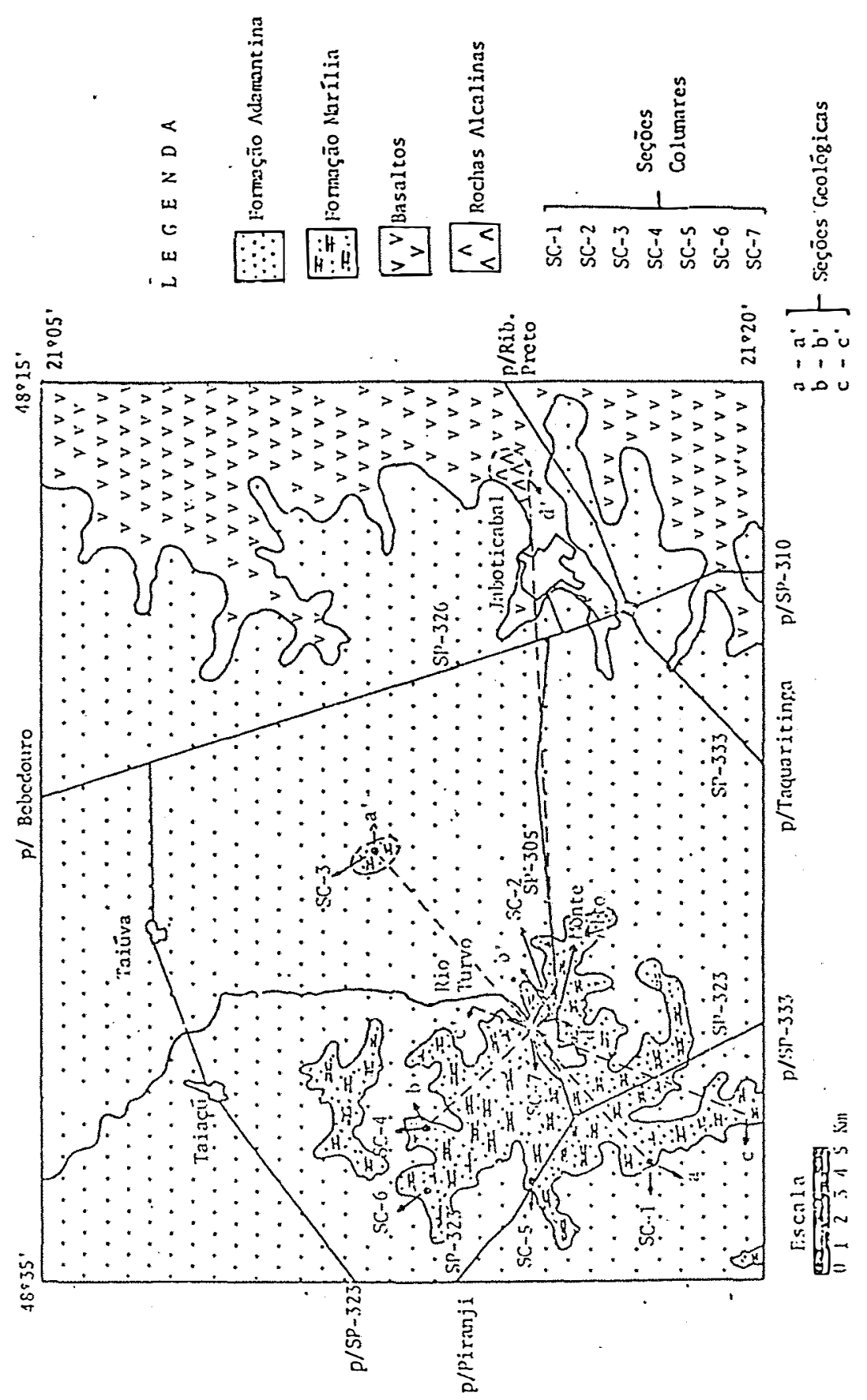

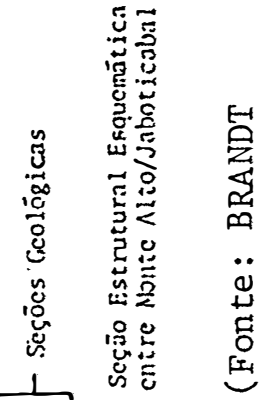
品

$\pi$ 
O quartzo é o mineral dominante dos arenitos desse grupo, ocorrendo subordinadamente os feldspatos, os quais ocorrem em maior quantidade na formação Marília, minerais instáveis tais como calcita, também podem estar presentes além de mica, e minerais pesados (ALMEIDA et al., 1980; ALHO, 1993). Segundo SUGUIO (1973), dentre os minerais transparentes, dominam a granada, turmalina, diopsídio e zircão e subordinadamente, cianita, espinélio, monazita, hornblenda, estaurolita, augita e titanita. Na fração argila desses sedimentos ocorre ilita (mica) e atapulgita (ou paligorskita) e, secundariamente, montmorilonita, clorita e caulinita, CASTRO (1989).

\subsubsection{A paleogeografia}

Para DANIELS \& HAMMER (1992), a reconstituição do ambiente deposicional é de grande contribuição para o entendimento e previsão da variabilidade do solo. A variabilidade textural vertical e horizontal de materiais de solo, é função da fonte, transporte e ambiente deposicional.

De acordo com SOARES et al. (1980) a formação Adamantina teria sido depositada em extenso sistema fluvial meandrante, com transições para anastomosados. Os arenitos com estratificação cruzada, passando a maciços e plano-paralelos, representam depósitos em barras de pontal ou transversais realizados nos canais. Os lamitos e siltitos foram depositados em planícies de inundação.

Com a progressiva diminuição da fase úmida e instalação de um clima semiárido, a energia tornou-se mais alta (regimes torrenciais), permitindo a deposição de detritos com cimentação carbonática tipo caliche. Os sedimentos resultantes dessas condições constituem a formação Marília (FIGURA 3). MANZINI (1990), sugere que os nódulos carbonáticos na região de Monte Alto, por apresentarem-se do tipo brecha ou conglomerado, tenham sido formados de pavimentos tipo caliche em outra área geográfica deste mesmo sítio deposicional, com remoção, retrabalhamento e deposição posteriores na região de Monte Alto. Porém há consenso em relação a interpretação do paleoclima semi-árido. SUGUIO (1973) e SUGUIO et al. (1980) atribuem a presença do mineral atapulgita como evidência da ocorrência do clima desértico. 


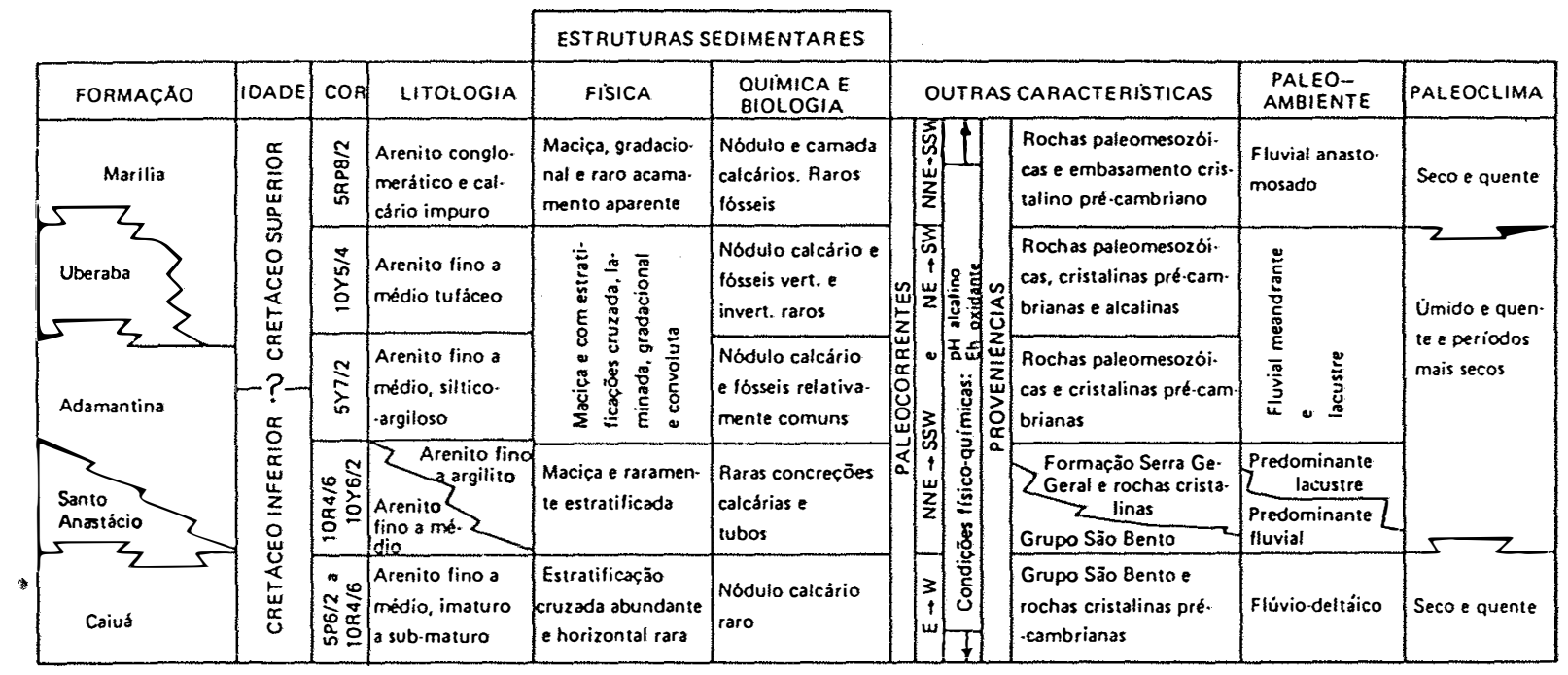

FIGURA 3. Fatores paleoambientais e paleoclimáticos e subdivisão estratigráfica do grupo Bauru. (Fonte: PETRI \& FÚlfFARO, 1983) 


\subsubsection{Implicações tectônicas regionais}

O trabalho de MANZINI (1990), revela que a região de Monte Alto (SP) foi submetida a intensa movimentação tectônica, com falhamentos e intrusão alcalina, sendo esta responsável pelo contexto do basculamento pós-Marilia na região.

À intrusão alcalina de Jaboticabal, de idade terciária (eoceno), seguiu-se intenso abatimento em toda área adjacente (FIGURA 4), condicionando vários rebaixamentos tectônicos da formação Marilia, explicando desta maneira, a preservação dos sedimentos deste grupo em Monte Alto. Por isso esses sedimentos foram resguardados da ampla erosão regional provocada pela instalação da drenagem do rio Turvo associada à instalação do rio Grande que aloja-se em zona de fratura crustal (HASUI et al., 1989; MANZINI,1990). A Formação Marilia, por ficar preservada no baixo tectônico, resistiu a mais esse ciclo erosivo, destacando-se no terreno como atual alto topográfico.

A região, portanto, apresenta-se como possuindo variabilidade litológica relativamente grande em relação à maior parte do restante do Planalto Ocidental mapeadas pelo IPT (1981) como formação Adamantina, à qual deve ser tomada em consideração para os estudos de seus solos. Vários trabalhos, PENTEADO \& RANZANI (1971, 1973); ALOISI (1973); JIMENEZ RUEDA \& DEMATTÊ (1988); DECHEN et al. (1994), destacam a grande influência da litologia nas propriedades e comportamento dos solos nesta região.

\subsection{Depósitos Cenozóicos}

Os depósitos cenozóicos do Planalto Ocidental Paulista correspondem a níveis escalonados da paisagem vinculados a fases de aplainamento. São coberturas correspondentes a mantos não consolidados, de espessura variável, que cortam os planaltos interioranos. Sua origem pode estar relacionada tanto a fatores advindos de mudanças climáticas como a fenômenos neo-tectônicos.

Vários autores consideram os depósitos cenozóicos como sedimentos inconsolidados assemelhando-se a solos, com níveis de seixos na base, recobrindo de maneira 


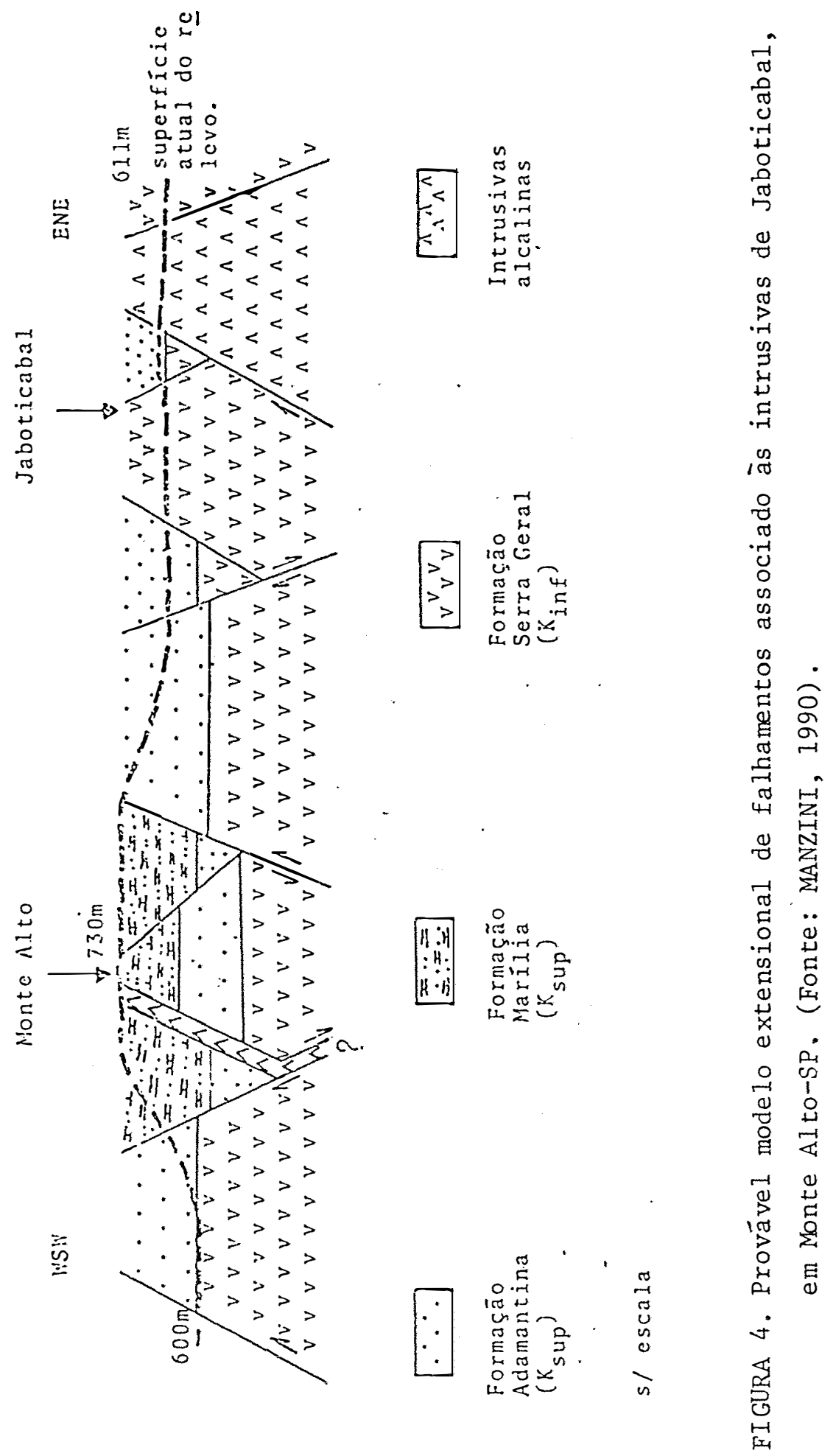


discordante outros tipos litológicos mais antigos do próprio cenozóico, mesozóico, paleozóico e até rochas do embasamento. As linhas de seixos na base são uma característica desses depósitos, sendo constituídos por quartzitos, silex e fragmentos de limonita (LANDIM et al., 1974; SOARES \& LANDIM, 1976; LEPSCH et al., 1977a e QUEIROZ NETO \& JOURNAUX, 1978).

Cascalheiras basais desses depósitos, na Serra de Santana, foram relacionados com ambientes de sedimentação em clima semi-árido (CHRISTOFOLETTI \& QUEIROZ NETO, 1966). MORAES REGO (1932) já havia registrado a idade terciária e quaternária desses sedimentos e sua distinção entre o pleistoceno e o recente.

A origem dos depósitos cenozóicos no Planalto Ocidental, foram atribuídos, por LANDIM et al. (1974) e SOARES \& LANDIM (1976), a fenômenos relacionados às superficies Sul-Americana e Velhas (KING, 1956). A primeira de idade terciária inferior (anterior à formação da Depressão Periférica), é distinta e seus depósitos associados se distinguem pela cor vermelho-escura, reflexo do enriquecimento em hematita. A superficie velhas seria de idade quaternária, e depósitos correlativos, encontrados na Depressão Periférica, e refletem nitidamente a fonte regional dos respectivos sedimentos.

LEPSCH (1976), descrevendo esses depósitos sobre o platô de Echaporã, reconheceu sua origem diferente daqueles do grupo Bauru, desconsiderando a possibilidade de origem " in situ ". Admite a dificuldade em definir o ambiente de deposição, porém sugere meio aquoso e transporte por agentes de grande competência, concordando com os processos de pedimentação em clima semi-árido (BIGARELLA \& ANDRADE, 1965). Depósitos similares na região de Marília, foram correlacionados ao segundo nível geomórfico referido no trabalho de QUEIROZ NETO et al. (1977), e registrados como areno-argilosos originados do retrabalhamento de depósitos em nível superior e da própria alteração do Arenito Bauru, correlacionados à várias fases de coluvionamento.

Apesar de algumas discordâncias entre vários autores sobre os eventos que mais contribuíram para origem dos depósitos cenozóicos, que estão entre questões climáticas e eventos tecto-sedimentares (CHRISTOFOLETTI \& QUEIROZ NETO, 1966; PENTEADO \& RANZANI, 1971; FÚLFARO \& SUGUIO, 1974 e LEPSCH, 1975), parece não haver desacordo em relação à cronologia dos episódios, uma vez que, para a região de 
Monte Alto (SP), os eventos tectônicos registrados por MANZINI (1990) datam do final do cretáceo e início do terciário, e são anteriores às variações climáticas do terciário médio e quaternário (BIGARELLA \& ANDRADE, 1965). Portanto, o registro da ocorrência dos movimentos tectônicos de Monte Alto (SP), não invalida o modelo das oscilações climáticas do quaternário. Pelo contrário, reforça a justificativa para ocorrência e preservação de depósitos neo-cenozóicos situados no alto topográfico regional. Estas considerações são relevantes porque a caracterização dos depósitos superficiais é de grande interesse para estudos pedológicos, uma vez que eles constituem o material de origem de grande parte dos solos (LEPSCH, 1975).

\subsection{Geomorfologia}

No cenozóico, principalmente a partir do plio-pleistoceno, teriam acontecido oscilações de clima semi-árido a tropical quente e úmido, até a ocorrência dos climas similares aos atuais. Isso está registrado nos trabalhos em áreas do Planalto Ocidental Paulista, por AB'SABER (1969); PENTEADO \& RANZANI (1973); LEPSCH (1975) e CASTRO (1989). Este modelo de alternância climática, ocorrido no quaternário (BIGARELLA et al., 1965), também foi aplicado em estudos regionais na Depressão Periférica Paulista, Alto Paranaíba (MG) e áreas do embasamento cristalino em Mococa (SP), (PENTEADO, 1968; CARMO et al., 1984 e VIDAL-TORRADO \& LEPSCH, 1993).

O Planalto de Monte Alto, porção mais elevada da Serra do Jaboticabal (ALMEIDA, 1964), cuja topografia é constituída de topo de encostas convexas de pouco aclive, que se desfazem gradativamente em direção à borda da escarpa. As escarpas verticais e subverticais, constituem um paredão, com desnivel desde a base até o topo, desde dezenas a uma centena de metros. O contorno da serra apresenta-se recortado, com alternância de paredões de rochas nuas e anfiteatros de erosão, normalmente recobertos de remanescentes da mata nativa. Morros testemunhos sobressaem-se na topografia das baixadas. A base da serra desfaz-se gradativamente em depósitos coluvionares e aluvionares de pequena expressão (BRANDT NETO, 1984). 
Segundo MANZINI (1990), a região de Monte Alto (SP) pode ser visualizada em duas áreas distintas. A NNE, onde se localiza a cidade recortada por relevos abruptos, característicos do contorno da serra, com predomínio de sedimentos da formação Marília, onde o principal curso de água é o rio Turvo com rede de drenagem de padrão treliçado, sugerindo que as rochas possuem diferentes graus de resistência à erosão. Uma segunda área representa um ramo isolado da serra, encontrando-se ao norte de Taquaritinga e possui um padrão de drenagem dendrítico, sugerindo resistência uniforme das rochas aos processos erosivos, e maior controle do seu caráter estrutural.

PENTEADO \& RANZANI (1971), classificam a região como inserida no Planalto de Jaboticabal, apresentando duas áreas morfológicas distintas: Cuestas de Monte Alto e Planalto Colinoso. As Cuestas de Monte Alto estão subclassificadas nos desdobramentos em superficie de cimeira, identificada como neogênico I (Pd2), de idade pliopleistocênica e com altitude de 700-740 metros; patamares abaixo da cimeira (Neogênico II P3); níveis intermediários de pedimentação (Superficie de Jaboticabal - P2); níveis baixos de pedimentação (Superficie de Jaboticabal - P2); níveis baixos de pedimentação (P1); baixos terraços ( $\mathrm{t}$ e tp) e, várzeas com altitude em torno de 620 metros.

Vários estudos com as mesmas preocupações, isto é, utilização de métodos geomorfológicos para estudos de solos, foram realizados no Planalto Ocidental Paulista, em áreas de ocorrência do grupo Bauru (QUEIROZ NETO et al., 1973; CARVALHO, 1976; LEPSCH et al., 1977a e QUEIROZ NETO \& JOURNAUX, 1978).

Os objetivos gerais parecem ser os mesmos que nortearam o início desses estudos no mundo: - estabelecer relações entre distribuição dos solos e fisiografia; - a dependência da gênese do perfil do solo à topografia; - o desenvolvimento paralelo dos solos com a paisagem e, - a influência dos processos geomorfológicos nos materiais de origem dos solos (JUNGERIUS, 1985). Porém diferenças de enfoque metodológico são evidenciados nos trabalhos, principalmente em relação à definição e datação das superficies geomórficas.

Para LEPSCH (1976), poucos são os trabalhos no Brasil que definem idade de superficie geomórfica com critérios de observação cuidadosa das quebras de gradiente no terreno, a exemplo dos modelos de RUHE (1969) e DANIELS et al. (1971). A maioria aplica métodos geomorfológicos referentes a níveis de erosão relacionados com superficies 
hipotéticas pretéritas, prescindindo em estabelecer relações de idade entre todas superficies atuais do terreno. BUTLER (1959) menciona que a definição de superficie por geomorfólogos, via de regra, não envolve o solo como critério, não podendo, portanto, relacionar sempre com os conceitos pedológicos de superficie. Porém DANIELS et al. (1971), acreditam que quando os estudos geomórficos são detalhados, a superficie de interesse de geomorfólogos e de pedólogos é a mesma.

\subsection{Solos}

\subsubsection{Os estudos de solos-geomorfologia}

Os estudos de solos-geomorfologia, entendidos como a integração da pedologia e geomorfologia, têm contribuído de maneira significativa para o entendimento de relações ambientais, básicas ao planejamento das atividades humanas.

GERRARD (1993), ao comentar a definição de pedologia como ciência que estuda os processos envolvidos na formação e diversificação de tipos de solos, e geomorfologia como a análise da natureza, arranjamento e diferenciação das formas da paisagem, bem como seus processos de formação, afirma que a inter-relação entre as duas disciplinas está implíscita na sua definição. Em decorrência, o trabalho interdisciplinar envolvendo as duas disciplinas é considerado de extrema importância (TRICART, 1968). CONACHER \& DALRYMPLE (1977), sugerem o desenvolvimento de uma nova disciplina, integrando geomorfologia e pedologia.

Importantes contribuições nesta área tem sido feitas por vários pesquisadores, dentre eles destacando-se os estudos de RUHE (1956), que através do mapeamento de superficies geomórficas por ordem cronológica (relativa ou absoluta), estabeleceu relações muito coerentes com o desenvolvimento dos solos: o grau de intemperismo e de evolução dos solos, diminuiu das superficies mais velhas para as superficies mais recentes.

A definição de superficie geomórfica foi um passo importante para o estabelecimento dos estudos de solo-geomorfologia. Assim "uma superficie geomórfica é uma 
porção de terra que é especialmente definida no espaço e no tempo" (RUHE et al., 1967) e que " tem limites geográficos definidos e é formada por um ou mais agentes num determinado periodo de tempo" (DANIELS et al., 1971). Seu reconhecimento deve ser norteado por alguns princípios: - a superficie é mais jovem do que qualquer outra ou material que ela corta; - é mais velha ou contemporânea aos depósitos de vale em posição topográfica inferior; - é mais jovem do que superficies adjacentes situadas em posição superior e portanto mais velha do que superficies adjacentes situadas em posição inferior; - é mais velha ou contemporânea aos depósitos sobre ela; - é mais jovem do que qualquer estrutura que ela corta em bisel.

Uma superficie geomórfica pode ser erosional ou deposicional ou ambas, DANIELS et al. (1971) e, normalmente em uma determinada área ocorre a presença de ambas essas feições. Quando expressas como superficies erosionais formam comumente uma série de degraus com idades decrescentes da mais alta para a mais baixa. Mas, atividades tectônicas e variações na litologia podem produzir morfologias da paisagem que podem ser confundidas com superficies erosionais.

O desenvolvimento efetivo de um solo não começa antes da erosão ou da deposição alcançarem uma estabilidade. Por conseqüência segundo esse ponto de vista, o solo num determinado local é de mesma idade que a da superficie na qual se forma (DANIELS et al., 1971).

Segundo RUHE (1975), cada solo ocupa um espaço e é descrito em três dimensões; tem limites definiveis e pode ser mapeado. Isto quer dizer que um solo está locado em determinadas formas da terra, ou em paisagens. A distribuição geográfica dos solos é a paisagem do mesmo, ou pedoforma. Então, caracterizar os diferentes compartimentos da paisagem, onde ocorrem processos superficiais e subsuperficiais distintos, é de grande importância para os estudos de relações solo-geomorfologia.

Um dos primeiros trabalhos de identificação e definição dos segmentos de encosta foi efetuado por WOOD (1942) enquadrando-os em quatro unidades: crista, escarpa, encosta e pedimento (FIGURA 5). RUHE (1960) à partir deste modelo identificou cinco segmentos em declives completos: interflúvio ("summit"), ombro ("shoulder"), encosta ("backslope"), pedimento ("footslope") e planície aluvial ("toeslope") (FIGURA 5). Este modelo de Ruhe foi adaptado por ele em 1975, seguindo a premissa: cada solo ocupa um 


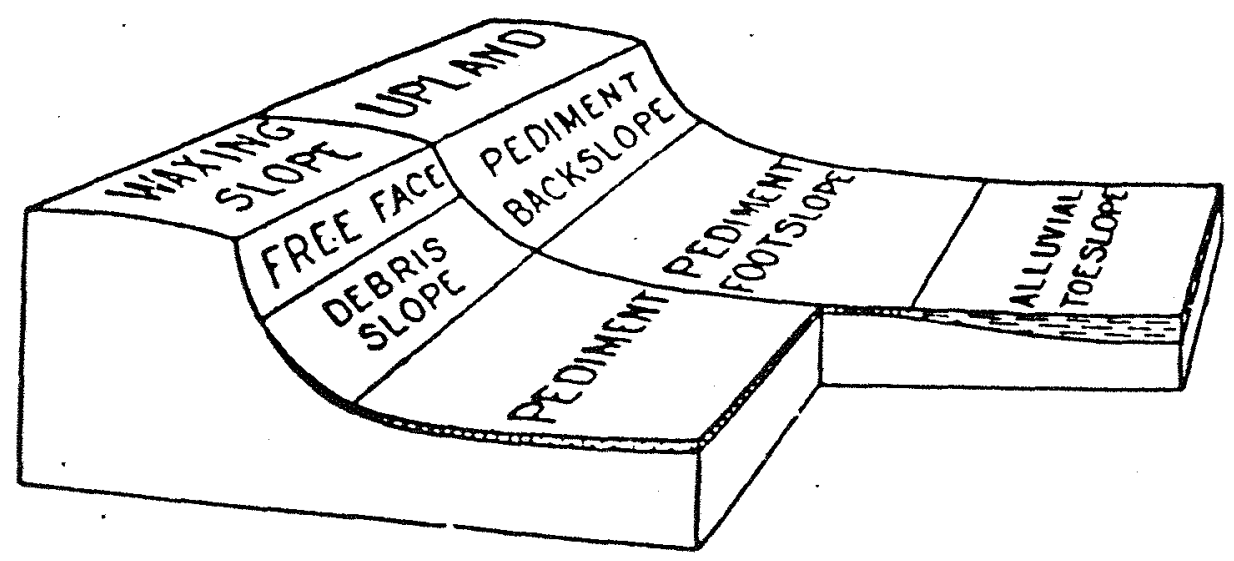

FIGURA 5. Segmentos da vertente. Em primeiro plano o modelo de WOOD (1942), e em segundo plano o modelo de RUHE (1975). 
espaço tridimensional e possui limites que podem ser definidos e mapeados, isto é, a distribuição geográfica do solo em paisagens é a paisagem do solo, ou pedoforma. Nas diferentes partes da paisagem ocorrem processos superficiais e subsuperficiais diferenciais. Então, a padronização de nomenclatura destes segmentos facilita a transferência de informação. Alguns destes segmentos podem não estar presentes numa paisagem; ou ainda pode haver sua repetição em diferentes superficies de uma paisagem.

MIINE (1935), trabalhando com mapeamento de solos na África, sugere o termo catena para designar unidade de mapeamento na descrição de repetições regulares de solos na paisagem. Considerou dois tipos de catena: simples, onde o material de origem é uniforme; neste caso as diferenças nos solos são resultados de diferenças na drenagem e do movimento lateral, tanto superficial como sub-superficial, de materiais. Na catena composta existe mais de um material de origem influenciando a gênese do solo.

A limitação do modelo catena, está no fato de não considerar os processos erosionais e sedimentológicos, que via de regra, ocorrem na maioria das paisagens. A morfologia e os processos de cada membro da catena que integram as suas partes, que por sua vez estão se ajustando continuamente às mudanças ambientais da paisagem, caracterizando processos contemporâneos (CONACHER \& DALRYMPLE, 1977).

Neste sentido, DARLYMPLE et al. (1968) iniciaram os estudos de proposição de um modelo de catena-paisagem, (FIGURA 6) que posteriormente foi aperfeiçoado por CONACHER \& DARLYMPLE (1977). Neste modelo o declive foi definido como uma unidade tridimensional que se estende do centro do interflúvio ao fundo do vale e da base do solo à interface solo-atmosfera. Foram identificadas e definidas nove unidades fundamentais, conforme características fisicas e morfológicas, registradas como respostas à processos pedogeomórficos recentes. Neste modelo registrou-se com grande ênfase as interações entre materiais do solo e a sua movimentação, translocação e redeposição pela água e gravidade, ocorrendo na superficie e subsuperficie do terreno. Considerado pedogeomórfico, por associar os processos geomórficos superficiais aos processos pedológicos de subsuperficie atuais, suas unidades podem mudar através de progressão ou regressão lateral, podendo estar parcialmente ausentes, ou repetidas na catena, constituindo assim, um modelo de grande potencial para os estudos em ambientes tropicais. 


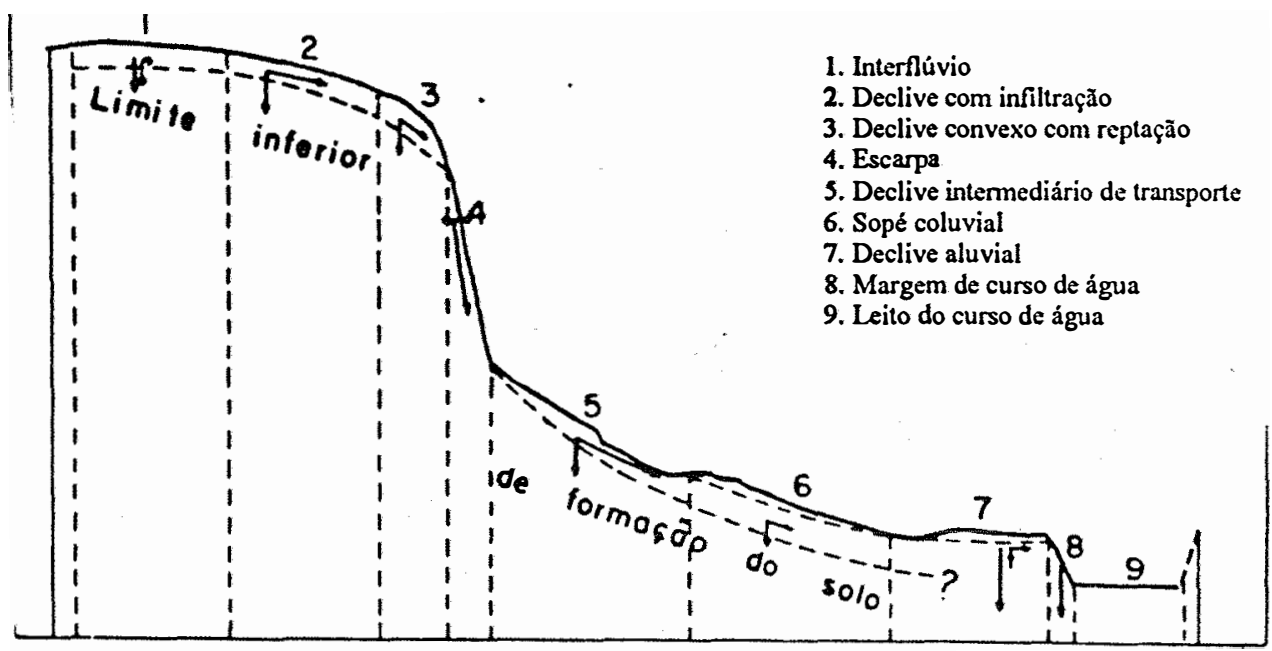

FIGURA 6. Modelo das nove unidades hipotéticas da vertente de DARLYMPLE et al. (1968). As setas indicam a direção e intensidade relativa do movimento do material de solo e fluxo da água no sistema. Fonte: CHRISTOFOLETTI, 1982. 
Outro incentivo ao desenvolvimento dos estudos de solos-paisagem, foi o reconhecimento dos ESTADOS UNIDOS (1951), de que os solos são corpos naturais (paisagens), além de perfis. Segundo JUNGERIUS (1985), sua grande contribuição para a padronização das descrições morfológicas, teria incentivado a difusão das idéias do solos como corpo natural na paisagem, e por conseqüência, dos estudos de solo-geomorfologia. Isto apesar das críticas feitas aos sistemas taxonômicos de maneira geral, pela pouca utilização da forma do solo (pedoforma). Porém, segundo os ESTADOS UNIDOS (1975), a pedoforna é proposta apenas para alguns grandes grupos ao nível de família.

Na Austrália, BUTLER (1959) propõe que uma superficie pode ser formada por vários ciclos desenvolvidos por interferência do clima e do tempo. A alteração da superficie numa fase de instabilidade, obstrui os processos pedogenéticos, até que uma nova fase de estabilidade permite o desenvolvimento do solo sobre esta nova superficie.

Os trabalhos de BUTLER (1959) e de RUHE (1969), auxiliaram nos problemas dos mapeamentos geomorfológicos regionais de grande escala, que não permitiam o reconhecimento de relevos de pequena expressão para informações mais detalhadas de estudos locais (LEPSCH \& BUOL, 1988).

LEPSCH (1975), registrou boas relações entre superficies geomórficas e solos no planalto de Echaporã (SP), concluindo que esta é uma importante interação para o entendimento da gênese e cartografia de solos. ESPÍNDOLA \& CARVALHO (1986), em estudo na bacia do rio Capivara, envolvendo as províncias geomorfológicas, Depressão Periférica, Cuestas Basálticas e Planalto Ocidental Paulista, encontraram relações com a mineralogia e ocorrência dos solos nestes compartimentos.

\subsubsection{Gênese dos latossolos}

Os solos com horizonte $\mathrm{B}$ latossólico caracteriza-se por sua grande homogenidade causada principalmente por atividade biológica de pedoturbação. Apresentam alto grau de intemperismo e poucos minerais facilmente intemperizáveis nas frações areia e silte, e na argila predominam caulinita e óxidos e hidróxidos de ferro e alumínio. A análise morfológica do perfil releva, na maior parte dos casos, a presença de estrutura com aspecto 
massiço "in situ", ou em blocos subangulares fracos, com agregados que se desfazem em microagregados de grau forte. Estes podem ser esféricos, ovais ou poliédricos e possuem origem diversa (BUOL \& ESWARAN, 1978; STOOPS, 1983; STOOPS \& BUOL, 1985).

Os trabalhos que estudam a origem dos microagregados em solos tropicais, revelam que sua origem pode estar associada a vários processos envolvendo principalmente modificações no plasma comportamento da mineralogia e atividade biológica.

BEADOU (1972) apresenta os microagregados como estrutura complexa formada por um núcleo rico em óxidos e hidróxidos de ferro envolvido por uma camada de fundo matricial pouco modificado. A formação dos microagregados é acompanhada por uma modificação do plasma que lentamente se individualiza e passa de massépico para insépico ou assépico, transformando a porosidade fissural inicial em porosidade de empilhamento individualizada. MULLER (1977) atribui esse rearranjamento do plasma à eventuais deslocamentos do ferro, com manutenção da cor, característica fisica considerada como importante processo de formação dos microagregados esféricos.

Os processos geoquímicos que atuam na formação dos microagregados, envolvem primeiramente a alteração ferralítica com neoformação de material ferro-caulinítico que evolui para caulino-gibbsítico após o desaparecimento dos minerais primários facilmente intemperizáveis (PEDRO et al., 1976). A fase ferro-caulinítica caracteriza-se pela união de cristalitos de caulinita dispostos paralelamente e ligados uns aos outros por pontes de ferro, denominados "policristalitos" (PEDRO, 1987). SANTOS et al. (1989) concluíram que o mineral de argila dominante na composição dos microagregados é pouco cristalino, densamente empacotado, caulinítico e orientado ao acaso. Alegam ainda que os oxihidróxidos de ferro pouco cristalinos (provavelmente ferridrita) que preenchem o espaço entre partículas de caulinita, tem um papel importante na união das partículas de argila; e que a combinação de partículas de argilas orientadas a o acaso, a matéria orgânica e os agregados de ferro imprimem aos microagregados sua natureza isotrópica.

Vários trabalhos informam sobre a importância da meso e microfauna no processo de formação de microagregados. Os estudos de ESCHENBRENNER (1986) à partir de um estudo com cupins em laboratório, evidenciou que o material formado pelos cupins é muito similar aos microagregados encontrados nos latossolos, concluindo que estes 
poderiam ter sofrido grande influência pela atividade dos cupíns em ambientes tropicais, processo denominado "bioagregação". Este mesmo processo foi observado por MIKLÓS (1993) estudando latossolo de basalto em Botucatu (SP). Outros trabalhos no Brasil registram a presença de microagregados e plasma isótico dominando o horizonte Bw (LEPSCH et al., 1977b; SANTOS et al., 1989; VITAL-TORRADO, 1994).

Portanto a microagregação é uma característica importante para identificação do horizonte $\mathrm{Bw}$, o que aliado à grande ocorrência dos latossolos no Brasil, incentiva a continuidade e o incremento dos estudos nesse sentido.

\subsubsection{Gênese de solos com B textural}

O enfoque central na discussão sobre a formação do horizonte B textural está fundamentado nos vários processos envolvidos no incremento de argilas, orientadas ou não, a que este horizonte apresenta.

Os estudos de BIRKELAND (1984) mencionam os três processos atualmente na formação desses horizontes; o primeiro seria a decomposição e movimento dos minerais de argila originados do intemperismo uma parte superior do perfil, para os horizontes subsuperficiais em solução aquosa; o segundo refere-se às argilas formadas "in situ" pelo intemperismo de minerais no horizonte $\mathrm{B}$; e o terceiro se refere às argilas que se movem como partículas em suspensão na água de percolação e que acumulam no horizonte $\mathrm{B}$ devido à floculação ou ao bloqueio dos poros. Os três processos podem atuar conjuntamente, porém a importância relativa de cada um deles varia com o tipo de solo.

A presença do horizonte eluvial acima do $\mathrm{Bt}$, estrutura em blocos e ausência de microagregados, são características imprescindiveis na identificação do B textural, para alguns autores (FEDOROFF \& ESWARAN, 1985). Outros atribuem ênfase à presença de cerosidade e cutãs como características principais para a classificação destes horizontes como Bt (ESWARAN \& SYS, 1979). Porém outros estudos mostram que nem sempre há uma correlação entre cerosidade observada no campo e a quantidade de cutãs de iluviação observadas nas lâminas delgadas. Vários motivos são apresentados: formação de argilas "in situ"pela ação de ciclos de molhamento e secagem ("stress" de cutã); estes mesmos processos 
de expansão e contração podem provocar a destruição dos cutãs de iluviação ou não formar superficies de agregados suficientemente permanentes para permitir o acúmulo e formação destes cutãs (NETTLETON et al., 1969; ISBELL, 1980). SOMBROEK (1990) acredita que esta discussão está em aberto uma vez que a natureza exata das superficies brilhosas na parede dos agregados é ainda incerta (exudação, metalização, cisalhamento, e/ou iluviação), bem como a origem das formas dos agregados.

Outro enfoque importante dos estudos sobre formação do horizonte Bt é o processo de sua degradação. CASTRO (1988) explica a degradação do topo do horizonte Bt pela ocorrência de depleção química seguida por ação mecânica. VIDAL-TORRADO (1991) para explicar o mesmo fenômeno, propõe que inicialmente ocorre iluviação de argila, seguido por redução da porosidade do topo do $\mathrm{Bt}$, encharcamento temporário que condiciona a degradação ou remoção lateral dos finos deste local. Porém ALMEIDA et al. (1995) estudando a formação de podzólicos abruptos, concluiu que para a formação do horizonte Bt, atuam ação de processos poligenéticos sucessiva ou concomitantemente. Argiluviação e destruição de argilas por fluxo lateral, todos contribuem para diferenciação textural do solo. Assim, para esses autores, a degradação do topo do horizonte Bt é fruto da ação de processos contemporâneos; e o alto gradiente textural, resultante de processos pedogenéticos pretéritos.

Os solos da região de Monte Alto (SP) foram primeiramente identificados e mapeados pela BRASIL (1960), como Solos Podzolizados de Lins e Marília, variação Marília (Pml), e variação Lins (Pln), caracterizados por serem solos com textura média no horizonte $\mathrm{B}$, desenvolvidos do produto de alteração do arenito Bauru com cimento carbonático, maduros (perfis com horizontes $\mathrm{A}, \mathrm{B}, \mathrm{C}$ ), com horizonte $\mathrm{B}$ textural $(\mathrm{Bt}$ ) resultante da acumulação por iluviação de frações finas, provenientes dos horizontes $\mathrm{A}$ e $\mathrm{E}$, que reveste a face dos agregados, dos canais e poros, na forma de películas denominadas em campo de cerosidade, que no caso pode ser fraca e descontínua. Estes solos correspondem nas classificações atuais aos Podzólicos Vermelhos-Amarelos textura arenosa/média, freqüentemente eutróficos (LEPSCH \& OLIVEIRA, 1987).

CASTRO (1989), estudando os solos da região de Marília (SP), menciona o histórico dos principais trabalhos sobre o assunto nesta região, principalmente à partir da 
década de 70, registrando como questões de destaque o material de origem e suas implicações pedogenéticas, eluviação e iluviação, e a questão da podzolização.

Com base em interpretações geomorfológicas, QUEIROZ NETO et al. (1973), e PENTEADO \& RANZANI (1973), interpretaram que horizontes mais superficiais dos podzólicos da região de Marilia (SP) foram originados de um ou mais colúvios ou remanejamentos. Os primeiros autores, observaram que ao longo da encosta das superficies de cimeira, os horizontes $\mathrm{A}+\mathrm{E}$ tornam-se cada vez mais espessos, e que a transição para os $\mathrm{B}$ texturais, tornava-se cada vez mais abrupta, e estes cada vez mais estruturados em direção ao sopé. Esses fatos e a presença de "stone lines" foram a base para os autores interpretarem os horizontes B e A como produtos de coluvionamento e remanejamento. Posteriormente QUEIROZ NETO et al. (1977) afirmaram que esses materiais coluvionados e remanejados correspondem a diversos períodos, sendo que o último período corresponderia aos horizontes A dos solos podzólicos da região de Marilia-SP, os quais não representariam horizontes pedogenéticos, stritu sensu, mas, sim, uma camada arenosa mais ou menos contínua sobre o material mais argiloso subjacente.

SUGUIO \& COIMBRA (1976) consideram que a diversidade de propriedades sedimentológicas existentes entre os solos e os sedimentos da formação Bauru são perfeitamente atribuíveis a diferenciações pedogenéticas de solos autóctones dessa formação.

JMENEZ-RUEDA \& DEMATTE (1988), atribuíram a origem do horizonte B textural de alguns podzólicos da região de Monte Alto (SP) aos lamitos que, via de regra, ocorrem na formação Marília.

\subsubsection{Variabilidade do solo}

Para WILDING \& DREES (1983), o estudo da variabilidade do solo tem por objetivo ajudar a delinear unidades de mapeamento pedológico que possuam condições de variabilidade menor do que uma determinada população de solos.

As propriedades do solo possuem uma variabilidade tanto casual, que não pode ser prevista a partir dos conhecimentos atuais, como sistemática a qual freqüentemente 
pode ser predizivel (DANIELS \& NELSON, 1987). Estas variações podem ser atribuídas por alguma combinação entre erro experimental, variação temporal e variação espacial (CAMPBELL, 1978). Pesquisas têm demonstrado que a variação espacial é usualmente a maior das três (CLINE, 1944 e BALL \& WILLIAMS, 1968).

A variabilidade sistemática é normalmente gradual, possui causa conhecida, entendida e prevista, e está marcada por mudanças nas propriedades do solo como uma função das formas da paisagem, elementos geomórficos, fatores de formação e/ou manejo do solo (WILDING \& DREES, 1983 e UPCHURCH \& EDMONDS, 1993). Para DANIELS \& NELSON (1987) a capacidade de previsão dessa variabilidade depende de pesquisas direcionadas ao entendimento dos processos que atuaram e continuam atuando no local da paisagem. Alegam ainda estes autores que as variações nas propriedades do solo são mais claramente expressas ao longo do gradiente hidráulico de superficie (HALL \& OLSON, 1991 e GERRARD, 1992). O modelo das nove unidades hipotéticas de paisagem de DALRYMPLE et al. (1968), confirma essa premissa, quando aponta a grande influência dos movimentos de água sub e superficiais, no condicionamento dos processos contemporâneos da paisagem.

No Brasil os trabalhos de MONIZ \& BUOL (1982); VIDAL-TORRADO \& LEPSCH (1993), confirmam a atuação desses fluxos na paisagem, influenciando sobremaneira as variações nas propriedades do solo.

Outro motivo para variação nas propriedades do solo está ligado à estratigrafia. A variação textural nos materiais de origem depende grandemente do ambiente deposicional dos sedimentos e tipo de rocha. A variação textural do arenito do grupo Bauru (mais fino na base e grosseiro no topo), é indicação de mudança do ambiente deposicional. DANIELS \& HAMMER (1992), alertam que os sedimentos de encosta, formados por processos diversos de movimento de massa, podem mascarar a variabilidade dos materiais subjacentes, salientando que colúvios, por exemplo, possuem variação nas propriedades que dependem da fonte e história pós-deposicional de cada local. DANIELS \& NELSON (1987), salientam que muitas descrições de unidades de mapeamento não reconhecem os sedimentos de encosta, porém sua influência na variabilidade do solo e produtividade de culturas, podem ser considerável. 
WEBSTER \& CUANALO (1975), estudando a variabilidade de solos através de transeção, sob várias condições ambientais, concluíram que a litologia foi a principal fonte de variação.

\subsubsection{Implicações da variabilidade na taxonomia e cartografia de solos}

Segundo WILDING \& DREES (1983), a partir de 1960, quando se iniciou a implementação da $7^{\mathrm{a}}$ aproximação do Soil Taxonomy (ESTADOS UNIDOS, 1975), unidades cartográficas representativas da série de solos, raramente foram encontradas com mais de $50 \%$ do solo designado no nome da unidade de mapeamento. Segundo estes autores isto é uma conseqüência do baixo grau de concordância entre o sistema taxonômico, como modelo conceitual, e as unidades cartográficas como contrapartes da paisagem real. Em um futuro próximo, porém, com a crescente utilização de levantamentos de solos para várias finalidades, muito será requerido em termos de precisão dos limites das classes de solos, ou do entendimento da variabilidade de suas propriedades.

Segundo BUOL (1990), a realidade da variabilidade dos solos em ambientes tropicais, foi mascarada pelos levantamentos de reconhecimento em pequena escala, que proporcionaram um falso sentido de uniformidade, o que contribuiu para ampliar a distância entre pesquisadores que interpretavam os mapas e os agricultores que queriam saber como era o solo que agricultavam. Alerta ainda que uma maneira de compensar a falta de dados é a caracterização quantitativa das propriedades dos solos.

Não sendo as propriedades dos solos idênticas em todas as partes do terreno o grau de variabilidade dependerá da escala de trabalho. A variabilidade dentro do pedon, é diferente da apresentada na unidade de mapeamento (variação do terreno). Apesar de ambas serem fundamentais para interpretação a respeito da produtividade do solo (DANIELS \& NELSON, 1987). CAMPBEL (1978) acredita que esta diferença é devido a grande dificuldade de aplicação prática das unidades de mapeamento, quando representadas por um único perfil modal. Outro agravante é a utilização de termos taxonômicos para nomear unidades de mapeamento de solos (BUOL, 1990). 


\subsection{A transeção como método de estudos de solos}

A utilização do método de observações sistemáticas ao longo de transeções cuidadosamente escolhidas, tem se revelado de grande eficiência nos levantamentos de solos, principalmente em áreas pouco conhecidas. WEBSTER \& CUANALO (1975), mencionam que, na fase preliminar ao estabelecimento das classes de solos, é imprescindível uma avaliação da variabilidade de suas propriedades, sua direção e magnitude. Transeções estabelecidas ao acaso ou sistematicamente, são medidas simples e econômicas que contribuem para facilitar uma visão rápida e precisa das unidades de solos, suas relações e seus limites. DANIELS \& NELSON (1987), reconhecem que o método de transeção é o mais adequado para aplicação de testes geoestatísticos, tendo em vista a investigação das causas da variabilidade das propriedades do solo.

A acurácia no estabelecimento das unidades de mapeamento, sempre foi uma grande preocupação das agências responsáveis pela elaboração dos levantamentos de solos. Nos EUA em 1988, foi iniciado um trabalho de avaliação dos modelos utilizados para estabelecimento de unidades dos mapas à partir dos levantamentos de solos de 1965. O método de transeções revelou-se muito eficiente para comparar diferenças entre unidades de mapas antigos e atuais. O citado método revelou, por exemplo, que em algumas unidades de mapas atuais, apenas $26 \%$ dos solos pertenciam a mesma classe taxonômica descrita nesta unidade em 1965 (WILDING \& DREES, 1983). HARTUNG et al. (1993) mencionam que a base científica dos levantamentos de solos é a capacidade de predição da ocorrência dos solos na paisagem. Esta relação faz o possível para gerar um modelo de mapeamento de solos que é testado no campo durante as atividades de mapeamento. O modelo não pode ser seguro com ausência de descrição de pedons, de anotações de campo, de transeções e de conhecimentos geomorfológicos.

Para WILDING \& DREES (1983), a transeção pode gerar informações que por vezes substitui um grande número de trincheiras, ou escavações freqüentemente desconectadas de informações sobre as características da vertente em pauta. Possui ainda a vantagem de possibilitar levantamentos de reconhecimento em áreas de dificil acesso, onde procedimentos convencionais seriam impraticáveis. Estes autores mencionam ainda que 0 
número de transeções, bem como o intervalo entre os pontos de amostragem, depende inicialmente da complexidade da área, como por exemplo, conhecimento prévio, relevo, tipo de vegetação e as finalidades do estudo.

No Brasil vários trabalhos tem revelado a validade das transeções nos estudos de solo-vertente (VIDAL-TORRADO \& LEPSCH, 1993 e COELHO et al., 1994), porém elas nem sempre são utilizadas nos levantamentos de solos.

\subsection{Testes estatísticos para aferição da variabilidade espacial}

A estatística univariada é pouco recomendada para estudos ambientais, uma vez que avalia o comportamento das variáveis duas a duas. Neste sentido, o trabalho torna-se puramente comparativo, produzindo resultados que permitem apenas testar certas hipóteses, direcionando os pesquisadores muitas vezes a resultados equivocados. Os métodos estatísticos e as modalidades de coletas de amostras tradicionais, normalmente são inadequadas para os estudos que visam descobrir e entender os processos responsáveis pela variabilidade do solo. Isto pelo fato de existir, nos estudos pedológicos, múltiplas populações exigindo um grande número de amostras para estimar parâmetros de interesse (DANIELS \& NELSON, 1987; UPCHURCH \& EDMONDS, 1993).

CAMERON et al. (1972) e CIPRA et al. (1972) examinando a variação das propriedades do solo, através do método de análise de variância, concluíram que este método não permite uma descrição concisa e completa das variações do terreno. WEBSTER (1978) e WEBSTER \& CUANALO (1975), obtiveram melhores resultados utilizando funções de autocorrelação ao analisar a variabilidade espacial de propriedades do solo.

Apesar da grande dificuldade em montar delineamentos experimentais controlados em estudos ecológicos, a análise multivariada permite a descrição de padrões de distribuição espacial, possibilitando não apenas o teste de hipóteses, mas principalmente a geração dela. Os principais objetivos dos métodos multivariados são: (a) simplificar a estrutura dos dados, transformando um conjunto de variáveis independentes em outro conjunto de variáveis interdependentes e de menor dimensão; (b) classificar as amostras, 
indivíduos ou variáveis em grupos com características semelhantes; (c) analisar a interdependência entre as variáveis; (d) formular e testar as hipóteses.

NORRIS (1970) ressalta as vantagens dos métodos de análise multivariada em levantamentos de solos, são justificados pela necessidade de síntese para entender sistema cujas propriedades não são independentes, porém interrelacionados em um meio complexo. Salienta ainda que esses métodos, embora utilizando técnicas matemáticas sofisticadas, na prática oferecem uma maneira simples de interpretação que favorece o entendimento de situações complexas na paisagem.

A necessidade de testar o conceito de classes de solo a partir de um número maior de propriedades, onde a similaridade entre elas fossem avaliadas com alta precisão, através de métodos de interpolação entre os pontos, foi defendida por vários autores (HOLE \& HIRONAKA, 1960; BIDWELL \& HOLE, 1964; RAYNER, 1966).

SNEATH \& SOKAL (1962) definiram a taxonomia numérica como sendo a da afinidade ou similaridade entre unidades taxonômicas e sua ordenação espacial. SIMPSON (1964) ponderou que dendogramas taxonômicos poderiam ser preparados para reduzir o número de propriedades selecionadas para classificação de solos, estabelecendo a previsão de que com a disponibilidade de computadores rápidos, este seria no futuro um importante campo de trabalho.

Porém BUOL et al. (1980) considera que não há maior problema para a taxonomia de solos do que a de estabelecer consistentemente limites reconhecíveis dos solos individuais. Limites que são vagamente definidos ou que podem ser reconhecidos somente sob condições muito especiais, adicionam confusão ao sistema. Mesmo com definições precisas de taxa de solos, o mapeamento consistente de corpos de solos correspondentes é dificultada.

Para ARNOLD (1983) a representação dos "taxa" que ocorrem na natureza tem sido feita por diferentes nomes pelos cientistas. Para este autor a necessidade de uma ponte à partir da estrutura dos "taxa" do esquema de classificação do solo, com os limites projetados de variabilidade de ocorrência natural na paisagem, tem sugerido como prática, limites de segmentos de paisagem que utilizem características externas que são consistentemente reconhecidas e capazes de delineação, e com boas correlações com as propriedades do solo. 
Estas idéias estão fortemente ligadas às observações de CLINE (1977), sobre a influência dos processos geomórficos na formação e evolução dos solos. Ele salienta que a influência dos eventos do Pleistoceno sobre a formação dos solos nos E.U.A., são bem maiores que os modelos genéticos possam prever.

As zonas de transição de uma unidade de mapeamento para outra é controlada pela natureza da paisagem, facilmente visualizadas pelas unidades de vertentes. $\mathrm{O}$ não reconhecimento detalhado destas zonas de transição muitas vezes é o responsável pelas dificuldades em transferir informações, de um local para outro, dentro de uma mesma unidade de mapeamento. Por isso é importante determinar com precisão, os limites entre classes de solos.

O método de locação estatística "split moving windows" apresentado por WEBSTER (1973), segue os princípios geoestatísticos, e tem como objetivo principal a avaliação da variação de propriedades do solo à distância (transeções), de maneira que se possa visualizar os limites entre agrupamentos com um mínimo de variância de suas propriedades. Assim o método examina uma transeção de série fixa de determinados gnupos de pontos adjacentes (janelas) que se movem através de toda extensão dos pontos amostrados, cujas médias de determinado atributo são sucessivamente comparadas ao longo da sequência, calculando-se os valores estatísticos do teste t. Estes valores de t, quando mais elevados, mostram mudança na propriedade observada, indicando limites de ambientes condicionados por mudanças nos processos controladores da formação do solo. 


\section{MATERIAL E MÉTODOS}

\subsection{Localização e caracterização do meio físico}

A área de estudo está localizada no norte da Estado de São Paulo, na região de Monte Alto (SP) (FIGURA 7), sendo definida pelas coordenadas aproximadas de $48^{\circ} 31^{\prime}$ a $48^{\circ} 29^{\prime} \mathrm{W}$ e $21^{\circ} 16^{\prime}$ a $21^{\circ} 13^{\prime} \mathrm{S}$. Ela faz parte dos bordos do Planalto Ocidental Paulista, compreendendo segundo Ab'SABER (1969) segmento dos baixos chapadões do oeste paulista.

O clima é do tipo "Cwa", segundo a classificação de Köpen, definido como mesotérmico de inverno seco, em que a temperatura do mês mais quente é superior a $22^{\circ} \mathrm{C}$ e a do mês mais frio é inferior a $18^{\circ} \mathrm{C}$. A precipitação anual é de aproximadamente $1.280 \mathrm{~mm}$, com distribuição mostrando concentração no período outubro-março e tempo relativamente seco entre abril e setembro.

A formação vegetal original foi denominada pela BRASIL (1960) como floresta latifoliada tropical subcaducifólia.

\subsection{Geologia, geomorfologia e solos}

A região está situada no Planalto Ocidental paulista, mais especificamente no planalto de Monte Alto, porção mais elevada da serra do Jaboticabal, com altitude aproximada de 760 metros, sendo representada por sedimentos do Grupo Bauru (Formações Marilia e Adamantina). Ela faz contato, a leste, com os basaltos da Formação Serra Geral e com algumas intrusões de rochas alcalinas (tinguaíto) (FIGURA 2). 


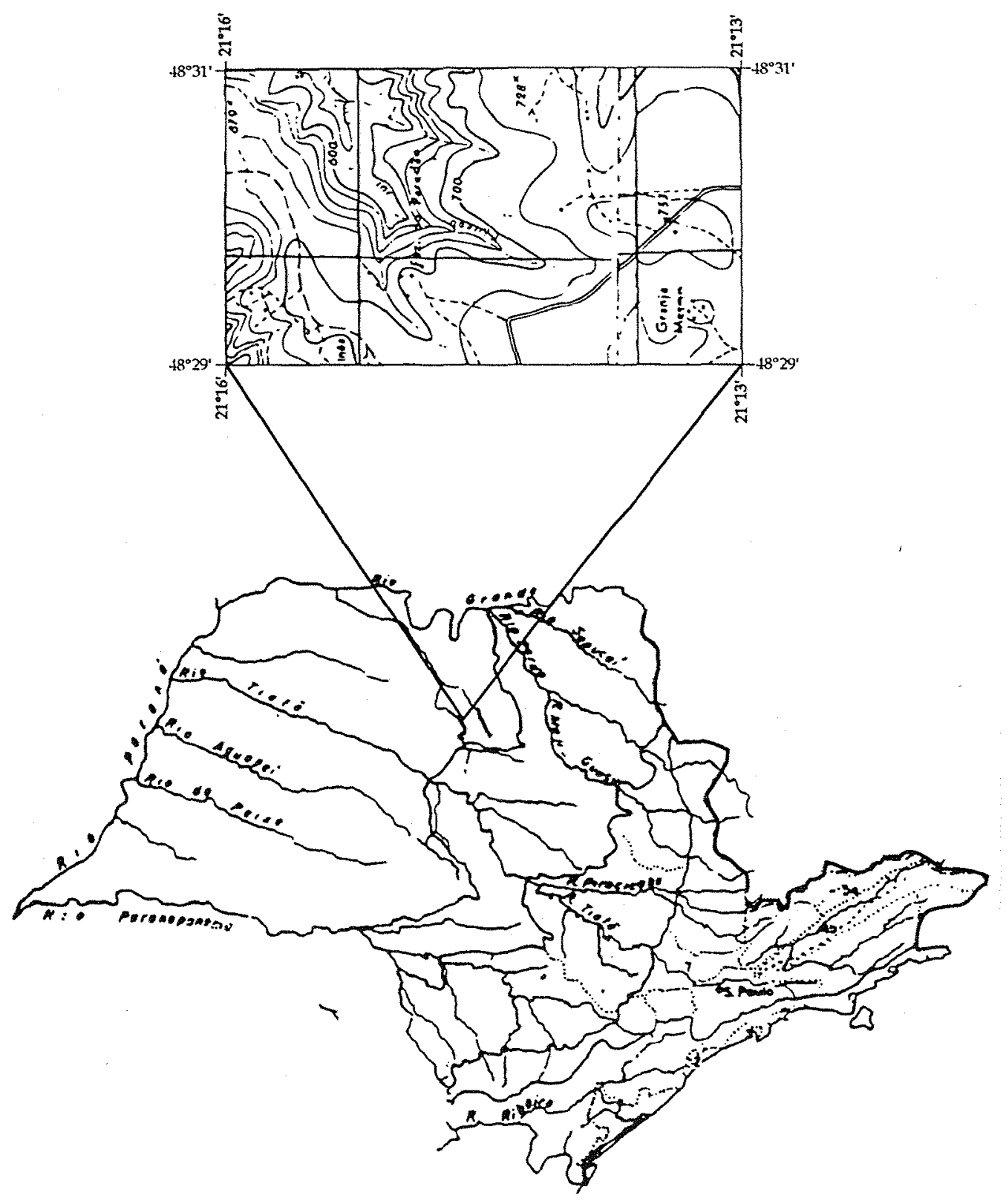

FIGURA 7. Localização da área de estudo no Planalto Ocidental Paulista. 
A porção mais elevada da região é caracterizada por encostas convexas com pouca inclinação, que passam gradativamente à uma escarpa arenítica (BRANDT NETO, 1984). Sua borda é marcada por escarpas verticais a subverticais, constituindo paredões, com desnivel, desde a sua base até o topo. A base da serra desfaz-se gradualmente em depósitos coluvionares de pequena expressão (MANZINI, 1990).

Os solos que predominam na região são os podzolizados de Lins e Marilia, variação Marilia e variação Lins (BRASIL, 1960). Litossolos e cambissolos ocupam as posições de escarpa, e a leste da serra do Jaboticabal, ocorrem os latossolos vermelhosescuros textura média e latossolos roxos, compondo os vales em "V" aberto.

\subsection{Metodologia de campo}

\subsubsection{Escolha da área à partir de uma transeção}

Foram utilizadas aerofotos na escala de 1:60.000, com o objetivo de identificar, na paisagem regional, as áreas correspondentes ao alto e baixo topográficos de maior e menor cotas, respectivamente. Identificou-se à noroeste da sede da cidade de Monte Alto, SP, próxima da torre de TV Record, a área de cota regional mais elevada com 763 metros de altitude. Posteriormente com o auxílio de aerofotos com escala maior (1:25.000) escolheu-se o direcionamento da transeção seguindo o espigão da vertente no sentido das cotas mais baixas até córrego dos Correias na fazenda Paredão, na cota 600, com uma distância de 2.700 metros.

Ao longo da transeção, o terreno foi estaqueado a intervalos regulares de 25 metros nos quais foram feitas mensurações de altitude para elaboração do perfil altimétrico, utilizando um nivel topográfico. Nesses mesmos pontos, coletou-se amostras de material de solo com o trado, predominantemente nas profundidades de 0 a 20 e 60 a $80 \mathrm{~cm}$. Nas posições da vertente onde os solos possuem horizontes superficiais $\mathrm{A}+\mathrm{E}$ muito espessos, coletou-se a amostra na segunda profundidade à partir do contato com o horizonte $\mathrm{B}$, mais argiloso. E nos locais de solos muito rasos, coletou-se amostras apenas na profundidade de 0 a $20 \mathrm{~cm}$. 
Uma área de 612,5 ha foi delimitada de modo que a transeção ocupasse sua posição central, e passou a constituir a unidade básica estudada, cuja fisiografia é representativa da região (FIGURA 8).

\subsubsection{Caracterização da área}

Nesta área, foi realizado o levantamento semi-detalhado de solos, segundo critérios da EMBRAPA/CNPS. O levantamento de solos foi realizado utilizando material cartográfico constituído por um conjunto de mapas planialtimétricos (escala 1:50.000), fotografias aéreas (escala 1:25.000) e levantamento topográfico (perfil altimétrico). As classes de declividade foram delimitadas diretamente a partir da carta planialtimétrica em escala de 1:50.000, segundo DE BIASI (1977), que se baseia na utilização de um ábaco que é passado entre duas curvas de valores diferenciadas, e posteriormente ampliadas para escala de 1:25.000, com apoio em fotos aéreas.

As superficies geomórficas foram identificadas e delineadas segundo critérios de RUHE (1969) e de DANIELS et al. (1971), com base no conceito de superficie geomórfica definido por RUHE (1969): "Uma superficie geomórfica é uma porção de superficie da terra que é especificamente definida no espaço e no tempo".

Com base no modelo de DALRYMPLE et al. (1968), foram reconhecidos e delimitados os segmentos da vertente, direcionados pela transeção escolhida: topo, encosta, ombro, escarpa, sopé de transporte e sopé coluvial. Estes foram correlacionados com as superficies geomórficas e unidades de mapeamento de solos.

Após um sorteio, 100 locais foram escolhidos para amostragens pontuais ao acaso dentro das superficies geomórficas, ao redor da transeção e, amostras de solo foram coletadas nestes pontos em duas profundidades ( 0 a $20 \mathrm{~cm}$ e 60 a $80 \mathrm{~cm}$ ). Posteriormente foram identificadas em quais superficies geomórficas e unidades de mapeamento de solos estes pontos pertenciam.

Perfis completos (sete trincheiras), representando as classes de solo presentes, foram descritos e amostrados, segundo critérios de LEMOS \& SANTOS (1984), com adaptações relativas à notação de horizontes preconizadas pela EMBRAPA/SNLCS 


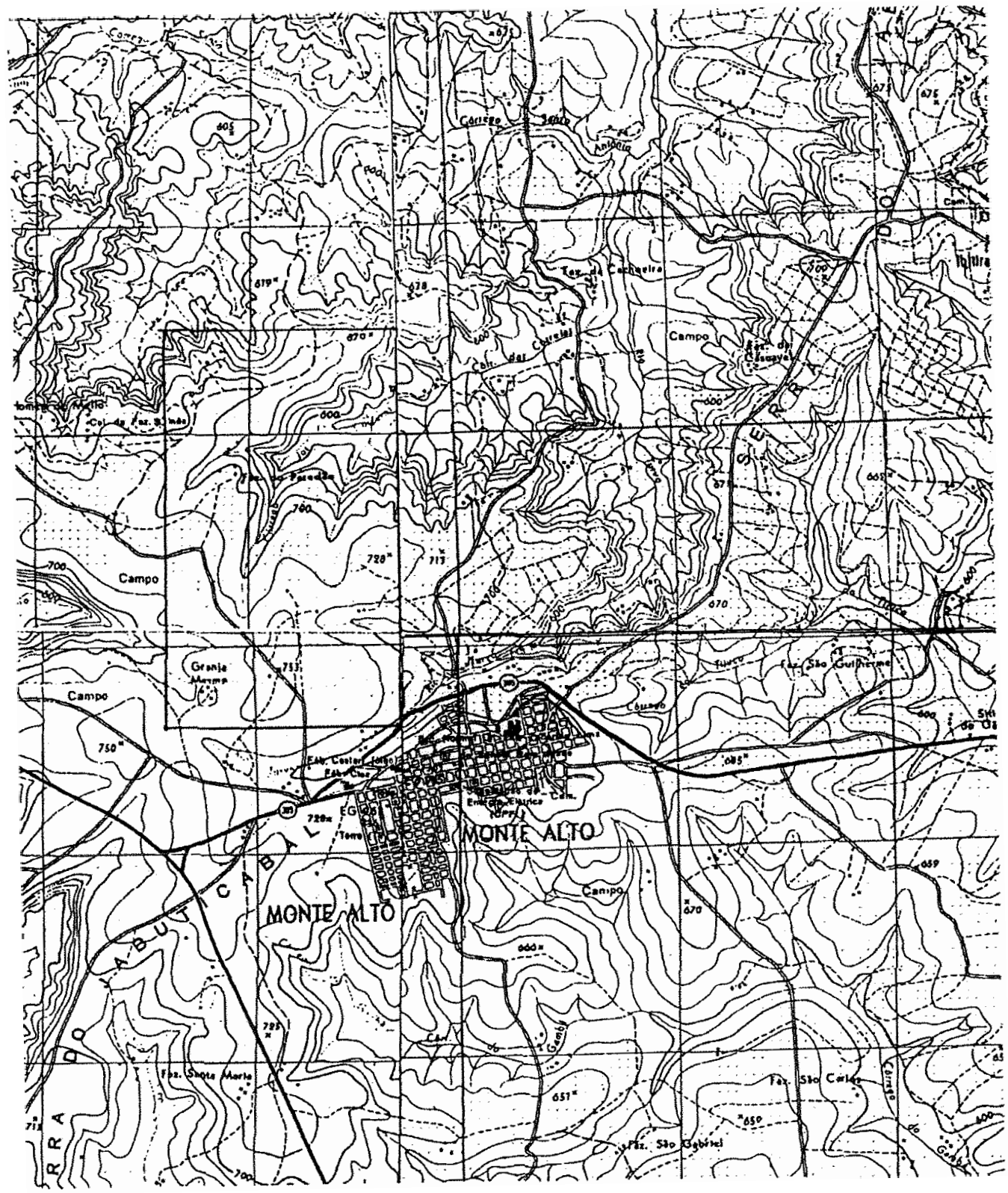

FIGURA 8. Mapa de localização da área de estudo. 
(1988). No fundo das trincheiras, quando possível, foram coletadas amostras com trado, a intervalos regulares de $40 \mathrm{~cm}$. Nesta etapa também foram coletadas amostras indeformadas para análise de densidade do solo e micromorfologia. Foram ainda avaliadas a homogeneidade do material de origem dos solos, à partir de observações e coletas em barrancos, em trincheiras e em tradagens profundas ( 2 a 10 metros de profundidade) feitas em três locais.

\subsection{Metodologia de laboratório}

\subsubsection{Caracterização física}

A análise granulométrica foi realizada pelo método da pipeta, utilizando uma solução de $\mathrm{NaOH}$ 0,1N como dispersante químico e agitação com aparato de alta rotação (12.000 rpm) (DAY, 1965). Para a argila dispersa em água, seguiu-se a metodologia descrita por VETTORI (1969) e EMBRAPA (1979).

A densidade de partículas foi determinada pelo método do picnômetro, segundo BLAKE (1965) e a densidade do solo em amostras com estrutura indeformada, coletadas com amostrador de Uhland, de volume conhecido (BLAKE, 1965).

\subsubsection{Caracterização química}

Cálcio, magnésio e potássio trocáveis e o fósforo disponivel foram extraídos utilizando-se o método da resina trocadora de íons (RAIJ et al., 1987). A acidez trocável $\left(\mathrm{Al}^{3+}\right)$ seguindo a metodologia de RAIJ \& ZULLO (1977), e o carbono orgânico segundo (EMBRAPA, 1979).

$\mathrm{O} \mathrm{pH}$ foi determinado potenciometricamente utilizando-se relação $1: 2,5$ de solo:água, solo: $\mathrm{KCl} 1 \mathrm{~N}$ e solo: $\mathrm{CaCl}_{2}$ 0,01M.

Os óxidos do ataque sulfúrico $\left(\mathrm{SiO}_{2}, \mathrm{Al}_{2} \mathrm{O}_{3}\right.$ e $\left.\mathrm{Fe}_{2} \mathrm{O}_{3}\right)$ foram determinados após digestão com $\mathrm{H}_{2} \mathrm{SO}_{4}$ 1:1 segundo o método descrito por VETTORI (1969), modificado por EMBRAPA (1979). 
Os óxidos de ferro livres totais (Fed) foram extraídos com ditionito-citratobicarbonato de sódio (DCB) em três extrações sucessivas, segundo metodologia de MEHRA \& JACKSON (1960), sendo a dosagem do ferro realizada através da espectrofotometria de absorção atômica.

No tocante aos óxidos de ferro extraídos pelo oxalato de amônio (Feo uma estração), seguiu-se a metodologia de SCHWERTMANN (1964). A dosagem do ferro foi realizada também por espectrofotometria de absorção atômica.

\subsubsection{Caracterização mineralógica}

A análise mineralógica qualitativa foi realizada com base nos difratogramas obtidos a partir de lâminas orientadas do material saturado com magnésio e potássio, a $25^{\circ} \mathrm{C}$, sendo que aquelas saturadas com potássio foram também aquecidas às temperaturas de $350 \mathrm{e}$ $550^{\circ} \mathrm{C}$. As amostras saturadas com magnésio foram irradiadas (tubo de cobre) em duas etapas, antes e após solvatação com etileno glicol.

Caulinita e gibbsita foram quantificadas, na fração argila desferrificada, através de análise térmica diferencial (ATD).

\subsubsection{Caracterização micromorfológica}

Amostras indeformadas e com orientação em relação a sua posição no perfil, foram impregnadas com resina de poliester. Após a impregnação dessas amostras, foram elaboradas seções delgadas para análise micromorfológica, a qual foi feita usando microscópio petrográfico Zeiss, segundo os critérios estabelecidos por BREWER (1976), com adaptações para a descrição da trama do solo segundo STOOPS \& JONGERIUS (1975) e LIMA et al. (1985). Fotomicrografias foram feitas em fotomicroscópio. 


\subsection{Análise estatísticas dos resultados}

\subsubsection{Análise estatística dos dados granulométricos}

Para a investigação da estratigrafia dos depósitos (colúvios) e descontinuidade de material de origem, foi realizada a análise estatística das distribuições das areias. Para tanto, a fração areia das amostras de interesse foi fracionada em cinco classes, que correspondem aos seguintes intervalos na escala phi: areia muito grossa (MG: -1 a 0 phi ou 2-1 mm); areia grossa (G: 0-1 phi ou 1-0,5 mm); areia média (M: 1-2 phi ou 0,5-0,25 mm); areia fina (F: 2-3 phi ou 0,25-0,105 mm), e areia muito fina (MF: $3-4,3$ phi ou 0,105-0,053 $\mathrm{mm}$ ). Utilizando-se o programa PHI para microcomputadores (JONG VAN LIER \& VIDAL TORRADO, 1992), os valores obtidos nas pesagens das areias foram tratados estatisticamente pelos critérios de Folk \& Ward, construindo se os gráficos de distribuição (em escala de distribuição normal) e os histogramas dessas distribuições.

\subsubsection{Análise estatística de parâmetros granulométricos e químicos do solo e das superfícies geomórficas}

Foram feitos testes de comparação de médias entre as diferentes superficies geomórficas e unidades de mapeamento de solos, utilizando-se como variáveis os atributos químicos e granulométricos de maior relevância para mapeamento de solos (EMBRAPA, 1988). Para esta análise foi utilizado o sistema estatístico STATGRAPHICS, no seu módulo de análise de variância unidirecional.

\subsubsection{Análise multivariada dos dados da transeção}

Foi realizada a análise de agrupamentos (análise de "cluster") para os parâmetros químicos e granulométricos da transeção, para comparar o grau de similaridade entre os grupos formados nas superficies geomórficas e unidades de mapeamento de solo. A estratégia de agrupamento utilizada foi a de "linkage average", para separar grupos com 
características homogêneas, utilizando a distância euclidiana como coeficiente de similaridade entre OTU's (agrupamento de estratégia hierárquica).

\subsubsection{Análise de locação estatística pelo "split moving windows"}

Foi realizado o teste de locação estatística dos limites do solo, segundo WEBSTER (1978), à partir de parâmetros químicos e fisicos de amostras do solo retiradas nos pontos da transeção.

\subsubsection{Avaliação indireta da erodibilidade dos solos}

A erodibilidade dos solos foi estimada pelo método indireto, para solos do Brasil, proposto por DENARDIN (1990), com o objetivo de comparar as tendências de erodibilidade dos solos nas superficies geomórficas. 


\section{RESULTADOS E DISCUSSÃO}

\subsection{Fisiografia - superfícies geomórficas e elementos de encosta}

\subsubsection{Visão geral da área e classes de declividade}

A área de estudo (FIGURAS 8, 9 e APÊNDICE 1) possui um pequeno topo (763 metros de altitude), seguido por encosta convexa de pouco aclive, que se desfaz gradativamente na direção da escarpa. Esta é vertical e subvertical, constituindo paredões, com considerável desnível, desde a sua base até o topo. A base da escarpa desfaz-se gradativamente em rampa que compreende o sopé de transporte e de depósitos coluvionares e aluvionares (600 metros de altitude), de pequena expressão (FIGURA 10).

A área possui classes de declives entre $0-2 \%$ nas posições de topo até maior que $45 \%$ na escarpa, sendo a classe de maior ocorrência de $2-5 \%$, seguida pela classe de 5 $10 \%$ e, as de menor ocorrência as que possuem declive menor que $2 \%$ e maior que $20 \%$ (QUADRO 1).

A região de ocorrência dos arenitos, de maneira geral, possui o padrão de declividade descrito acima (QUADRO 1). As escarpas, estão mais associadas à formação Marília, ou áreas limítrofes com a formação Adamantina, e estão, via de regra, cobertas por vegetação. Esta escarpa divide a área de estudo em duas partes, uma à montante nas posições mais elevadas e outra, constituindo os vales (600 m de altitude), onde existe a maior heterogeneidade de ocorrência de classes de declive (QUADRO 1).

Os topos quase planos são pouco freqüentes, de pequena extensão com altitudes concordantes aproximadamente $760 \mathrm{~m}$ (FIGURA 9), o que sugere serem 


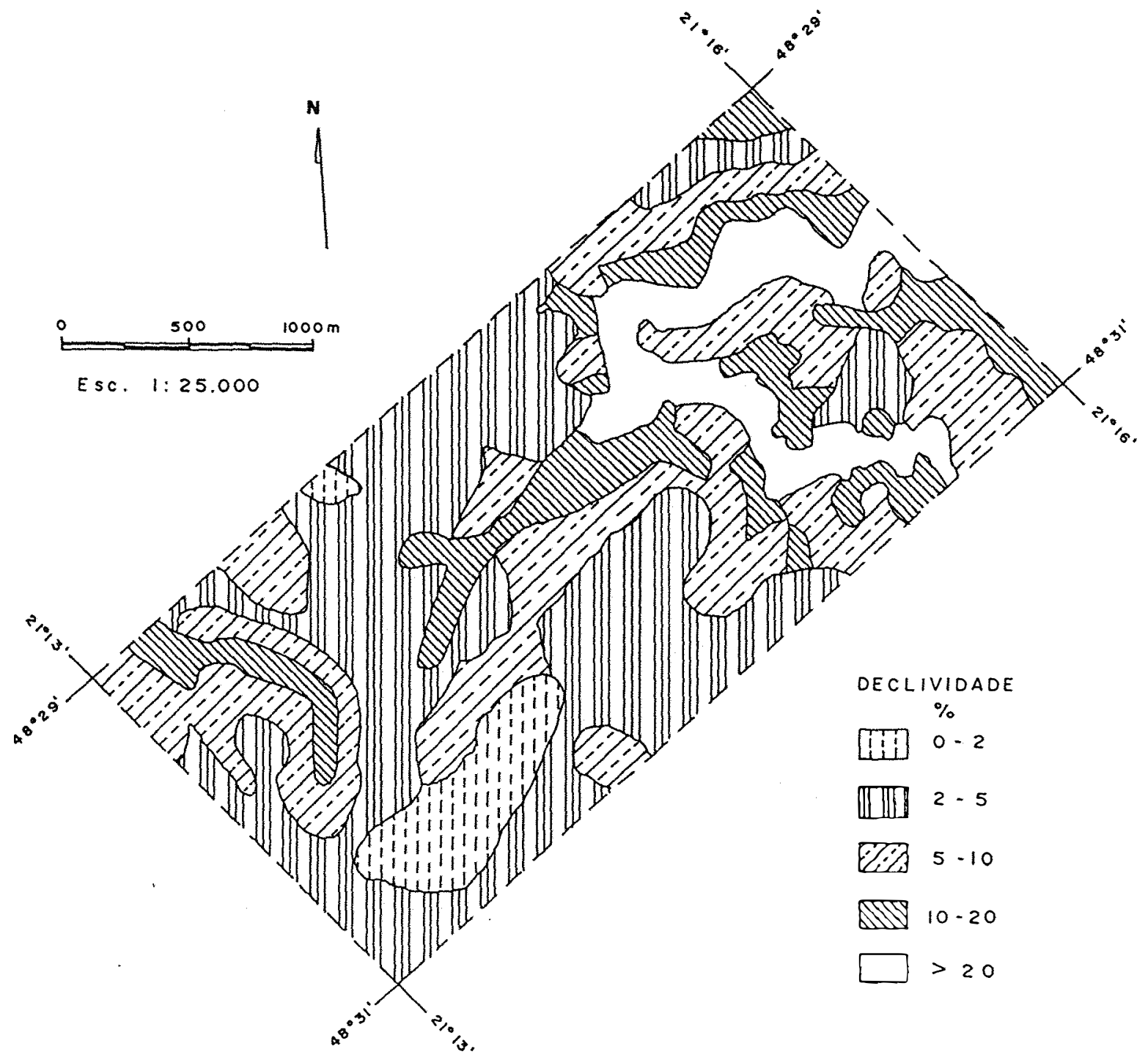

FIGURA 9. Classes de declive da área em estudo. 


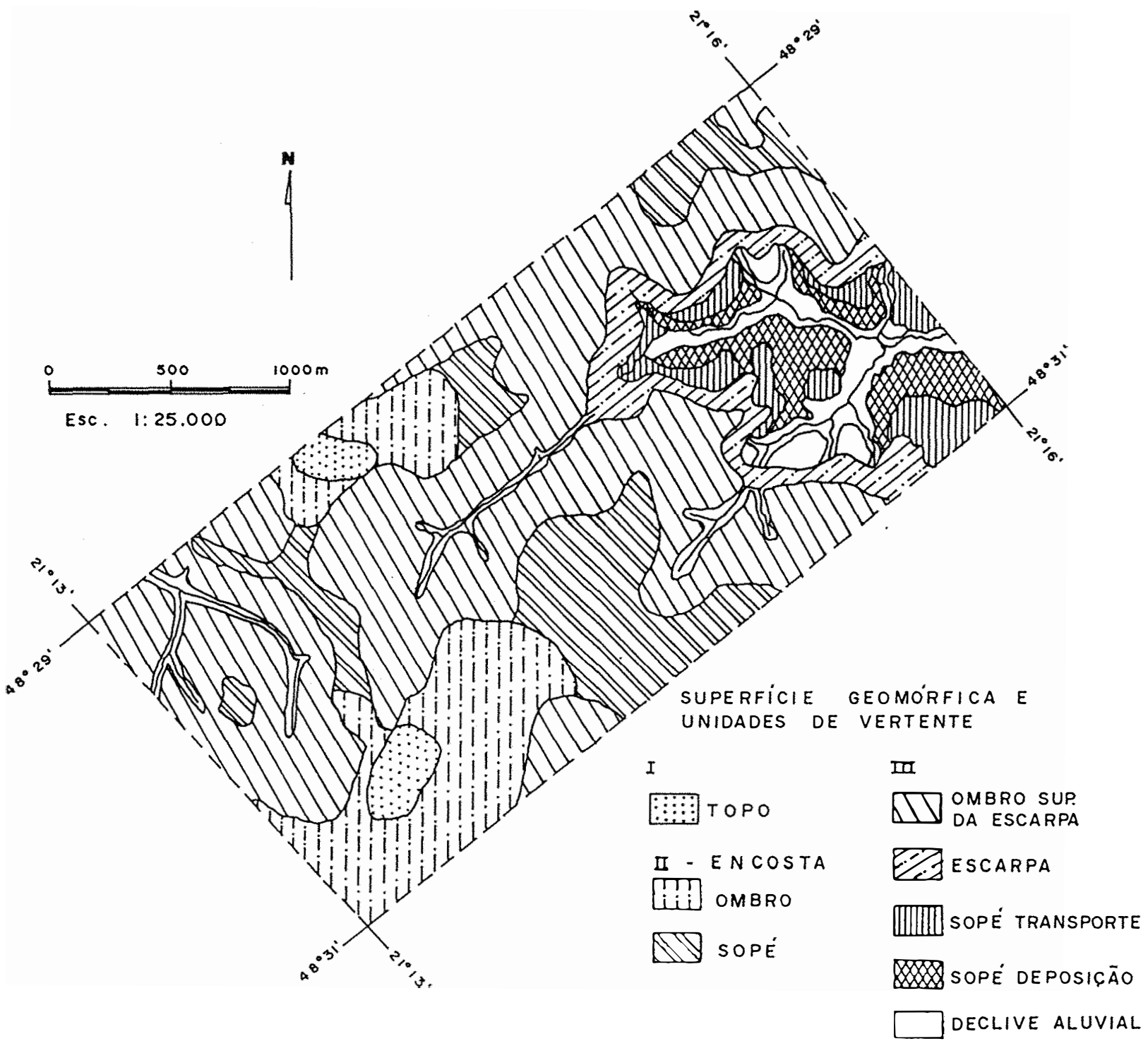

FIGURA 10. Superficie geomórfica (I, II e III) e seus compartimentos dentro da área de estudo. 
QUADRO 1. Freqüência de ocorrência e área das classes de declive.

\begin{tabular}{|c|c|c|}
\hline Classes de Declive (\%) & Área (ha) & \% Área Total \\
\hline$\leq 2$ & 32,8 & 5,3 \\
$2-5$ & 262,5 & 42,9 \\
$5-10$ & 170,3 & 27,8 \\
$10-20$ & 93,8 & 15,3 \\
$\geq 20$ & 53,1 & 8,7 \\
\hline
\end{tabular}

Área total $=612,6$ ha.

remanescentes de superficies pretéritas mais planas e mais extensas. Seus limites gradam para classes de declive mais acentuadas de maneira perceptível, podendo indicar um processo de erosão regressiva.

As linhas de drenagem mais expressas estão associadas às classes de declive de $10-20 \%$, podendo ser observado um processo de degradação intensa pela proximidade das áreas de cultivo e ausência de vegetação nas margens dos mananciais.

Portanto, a visão da distribuição das classes de declive na área, associando relevo relativamente movimentado em áreas de solos arenosos e intensamente cultivados com culturas anuais, revela ser uma área em sua maior parte naturalmente instável que demanda grandes cuidados em termos de práticas conservacionistas, que estão muito condicionadas à classe de declive.

\subsubsection{Superfícies geomórficas e segmentos de vertente}

Foram identificadas e mapeadas três superficies geomórficas (DANIELS et al., 1971), e sete segmentos de vertente ou elementos de encosta, segundo o modelo de DALRYMPLE et al. (1968) (FIGURA 10). A frequência de ocorrência e áreas das superficies e seus segmentos de vertente são mostradas no QUADRO 2.

A superficie I, localizada na parte mais elevada da área $(763 \mathrm{~m}$ de altitude), a maior cota regional, é constituída por dois topos distintos, de pequena 
extensão (3\% da área em estudo), e foi caracterizada por PENTEADO \& RANZANI (1971) como uma área de cimeira neogênica de idade plio-pleistocênica, que seria correspondentes ao Pd2 de BIGARELLA \& ANDRADE (1965). Aqueles autores relatam a postura inicial de aplainamento dessa superficie pós-cretácica, elaborada como assoalho (deposicional) primitivo regional sobre o arenito Bauru. Após este evento, ocorreu o estabelecimento da drenagem para as pretéritas bacias dos rios Mogi, do Tietê e do Turvo. As modificações nesta superficie foram mais drásticas com a ocorrência do clima semi-árido no Plioceno, que instalou um processo de degradação, esculpindo o pediplano de Monte Alto, portanto caracterizando também uma superficie erosional.

Segundo o modelo de DANIELS et al. (1971), esta é a superficie mais velha da área. Seus limites inferiores são interceptados pelas superficies II e III (FIGURA 10), que por este motivo são consideradas mais novas. Pela sua posição esta superficie pode ser considerada aquela que permaneceu mais estável por um período de tempo maior, representando portanto um importante testemunho de uma superficie pretérita, outrora mais extensa, e de maior estabilidade.

Os locais onde o declive é um pouco mais acentuado, 2-10\%, coincidem com a área de ocorrência da superficie II, que é caracterizada, na seqüência da encosta, como possuindo os elementos ombro (ou "pediment backslope", segundo RUHE, 1975 FIGURA 5), e uma área, possivelmente de deposição um pouco menos declivosa, identificada como um pretérito sopé ("pediment footslope, segundo RUHE, 1975 - FIGURA 5). É uma superficie predominantemente erosional, e seus limites são bastante claros, tendo sido provavelmente formada sob condições semi-áridas (P2 ou P1 de BIGARELLA \& MOUSINHO, 1965).

Esta superficie representa 30\% da área (QUADRO 2) e corta a superficie I na maior parte de seus limites à montante. A juzante os limites desta superficie são interceptados pela superficie III, de maneira mais acentuada (FIGURAS 10 e 22).

A superficie III, de idade holocênica, é constituida pelos segmentos de vertente (FIGURA 6) ombro, escarpa, sopé de transporte, sopé de deposição e declive aluvial. Esta superficie possui características erosionais intensas, ocupando mais de $50 \%$ da área em estudo (QUADRO 2). Ela está articulada em diferentes locais, conectando-se diretamente 
com qualquer uma das demais superficies identificadas (em menor extensão com a superficie 1), situando-se como uma área das mais instáveis, incluindo a escarpa ingreme ( $>45 \%)$, fortemente erosional, onde grandes blocos da formação Marília são expostos.

QUADRO 2. Freqüência de ocorrência e área das superfícies geomórficas e segmentos de vertente.

\begin{tabular}{|c|l|c|c|}
\hline Superficie geomórfica & Segmento de vertente & Área (ha) & \% da área Total \\
\hline I & Topo & 18,8 & 3,0 \\
& Ombro & 90,6 & 14,8 \\
& Sopé & 92,2 & 15,1 \\
& & & \\
& Ombro & 262,5 & 42,9 \\
& Escarpa & 45,3 & 7,4 \\
& Sopé de Transporte & 18,1 & 4,6 \\
& Sopé de Deposição & 34,4 & 5,6 \\
& Depósito Aluvial & 40,6 & 6,6 \\
\hline
\end{tabular}

Área Total $=612,5$ ha.

O ombro da escarpa é um elemento importante por sua extensão (43\% da área) e por interceptar todos os segmentos das supeficies I e II, representando a área de ligação entre as superfícies estudadas. Toda a rede de drenagem à montante da escarpa está inserida neste segmento. Isto implica que a área em estudo, representativa das escarpas areníticas regionais, encontra-se em um intenso processo de rejuvenescimento.

Em seqüência à escarpa, foram mapeados os sopés de transporte e de deposição, seguidos por depósitos aluviais, que são cortados pelo córrego Correias, afluente do rio Turvo. A porcentagem de ocorrência dos depósitos aluviais está superestimada devido à limitações do "software" utilizado para enquadramento de pequenas áreas mapeadas.

Observa-se que o modelo das unidades hipotéticas de vertente, desenvolvido por DALRYMPLE et al. (1968), oferece uma visão mais detalhada do terreno, cujos aspectos 
estão fortemente ligados ao conceito morfológico de superficie, e a processos contemporâneos da paisagem, enquanto o modelo de DANIELS et al. (1971) baseia-se na distribuição e datação relativa das superficies e, o reconhecimento de seus limites está fundamentado nas observações de campo e de aerofotos, e depende de interpretação genética da evolução da paisagem. Confirmou-se aqui também a pressuposição de que nas superficies mais estáveis pode haver dificuldades no mapeamento dos solos quando os mesmos estão em áreas de manejo agrícola intensivo por muito tempo (VIDAL-TORRADO, 1994). Solos originais, em conseqüência disto, modificam-se consideravelmente principalmente no que diz respeito às características químicas.

Acredita-se, portanto, que ambos modelos são complementares para o reconhecimento dos compartimentos naturais do relevo, principalmente quando os aspectos requeridos estão ligados ao entendimento da evolução da vertente, e suas relações com os processos atuais.

\subsubsection{Ocorrência dos depósitos superficiais}

Sob as superficies I e II, está um depósito neocenozóico com espessura da ordem de uma dezena de metros, identificado em locais de cotas mais elevadas da área (FIGURA 10).

Os resultados da análise estatística das areias dos depósitos identificados na área de estudo são mostrados nas Figuras 11, 12 e 13. Os resultados das análises químicas das amostragens profundas estão no Apêndice 6 .

O depósito neocenozóico possui areias com diâmetro relativamente uniforme até a profundidade de $8 \mathrm{~m}$, e apresenta uma descontinuidade a $9 \mathrm{~m}$, detectado por um aumento da mediana das areias de maior diâmetro (FIGURAS 11,12 e 13), evidenciando uma proximidade do assoalho do depósito, o qual não pôde ser atingido devido a limitações do aparelho usado para amostragem (trado holandês com extensão do cabo). Nesta posição foram encontrados seixos de quartzo em avançado estado de intemperismo, e a cor do solo que na superficie era de 5YR (vermelho) passou para 10YR (vermelho-amarelado), na profundidade de 9 metros. 
$\mathrm{Na}$ base do depósito, ao norte da área (segunda amostragem profunda), foi encontrada uma linha de pedras bastante evidente, em um corte vertical ao longo da estrada rural. São seixos de material ferruginoso com algum quartzo (com aspecto muito

Esta linha de pedras, considerada por FÚLFARO \& BARCELOS (1991) como característica de ocorrência peculiar à base dos depósitos cenozóicos, é constituida via de regra, por quartzitos, silex e fragmentos de limonita. Sua ocorrência na base de depósitos cenozóicos no estado de São Paulo foi registrada por vários autores (LANDIM et al., 1974; SOARES \& LANDIM, 1976; LEPSCH et al., 1977a e QUEIROZ NETO \& JOUNAUX, 1978). Registrados como de idade terciária e quaternária (MORAES REGO, 1932), esses depósitos foram relacionados com ambiente de sedimentação em clima semi-árido (CHRISTOFOLETTI \& QUEIROZ NETO, 1966).

De acordo com o modelo de LUCAS et al. (1990), clima úmido e níveis de base adequados, em locais favoráveis à concentração de ferro, favorece a plintização e, a posterior alternância climática e dos níveis de base, é condição para a formação da petroplintita, cuja degradação geoquímica dá origem aos nódulos ferruginosos alinhados.

Segundo PENTEADO \& RANZANI (1971), este depósito cenozóico na região de Monte Alto-SP constitui um remanescente, cujos processos de origem foram instalados no pós-cretáceo, passando por eventos tectônicos, que causou falhamentos com desnivelamentos de blocos, até a instalação de clima semi-árido pliocênico. Estes eventos remodelaram uma antiga superficie e condicionaram um remanejamento desses depósitos, elaborando nova cobertura detrítica que foi retrabalhada tantas vezes quantas foram as fases erosivas posteriores que atuaram no planalto.

LEPSCH (1975) estudando uma área similar em Echaporã,SP, identificou depósitos superficiais de mesma idade (início no plioceno em clima semi-árido), justificando que essas superficies neogênicas, com seus depósitos correlativos ocupavam áreas pretéritas em porções maiores no Planalto Ocidental. A oscilação climática entre o semi-árido e úmido (BIGARELLA \& ANDRADE, 1965) seria responsável pelo entalhamento dos vales, formando as superficies mais novas sobre os arenitos da formação Marília. 
$0-28 \mathrm{~cm}$

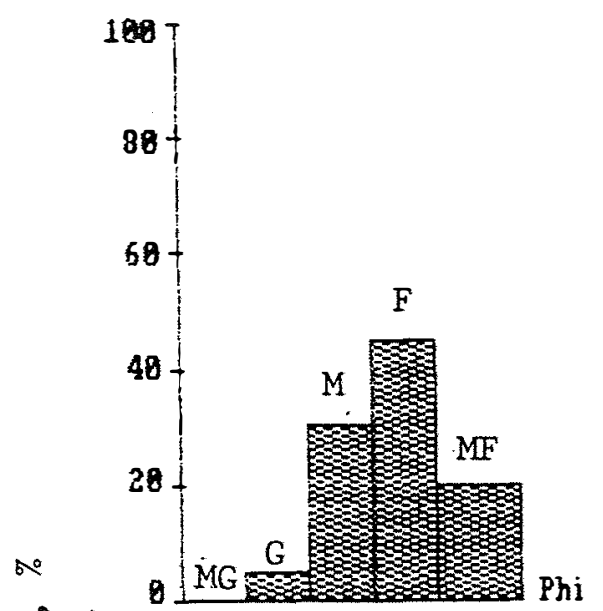

$6.8-6.28 \mathrm{~m}$

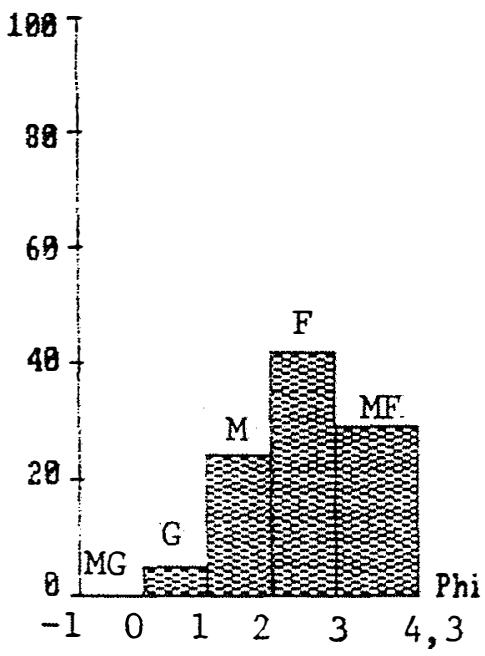

$1.8-1.28 \mathrm{~m}$

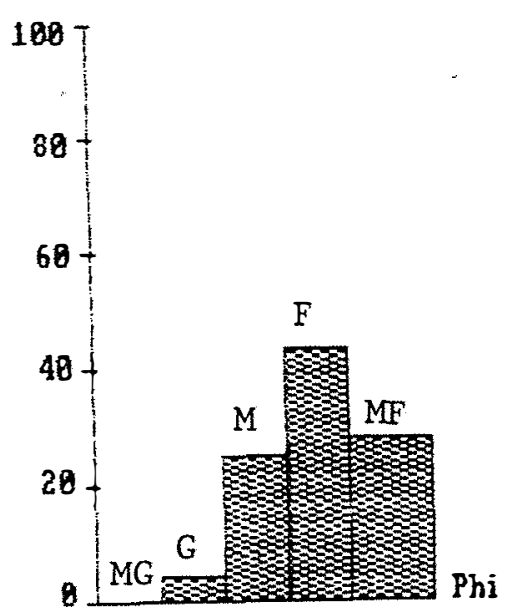

$9.8-9.28 \mathrm{~m}$

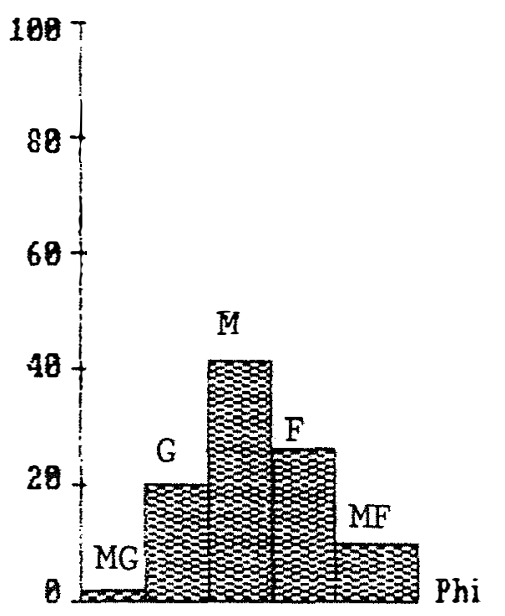

$\begin{array}{llllll}-1 & 0 & 1 & 2 & 3 & 4,5\end{array}$

TAMANHO DE PARTICULA, Phi

FIGURA 11. Histogramas da distribuição de partículas em cinco classes granulométricas de areia (MG: areia muito grossa; G: areia grossa; M: areia média; F: areia fina; MF: areia muito fina) em quatro profundidades selecionadas, da primeira amostragem profunda. 

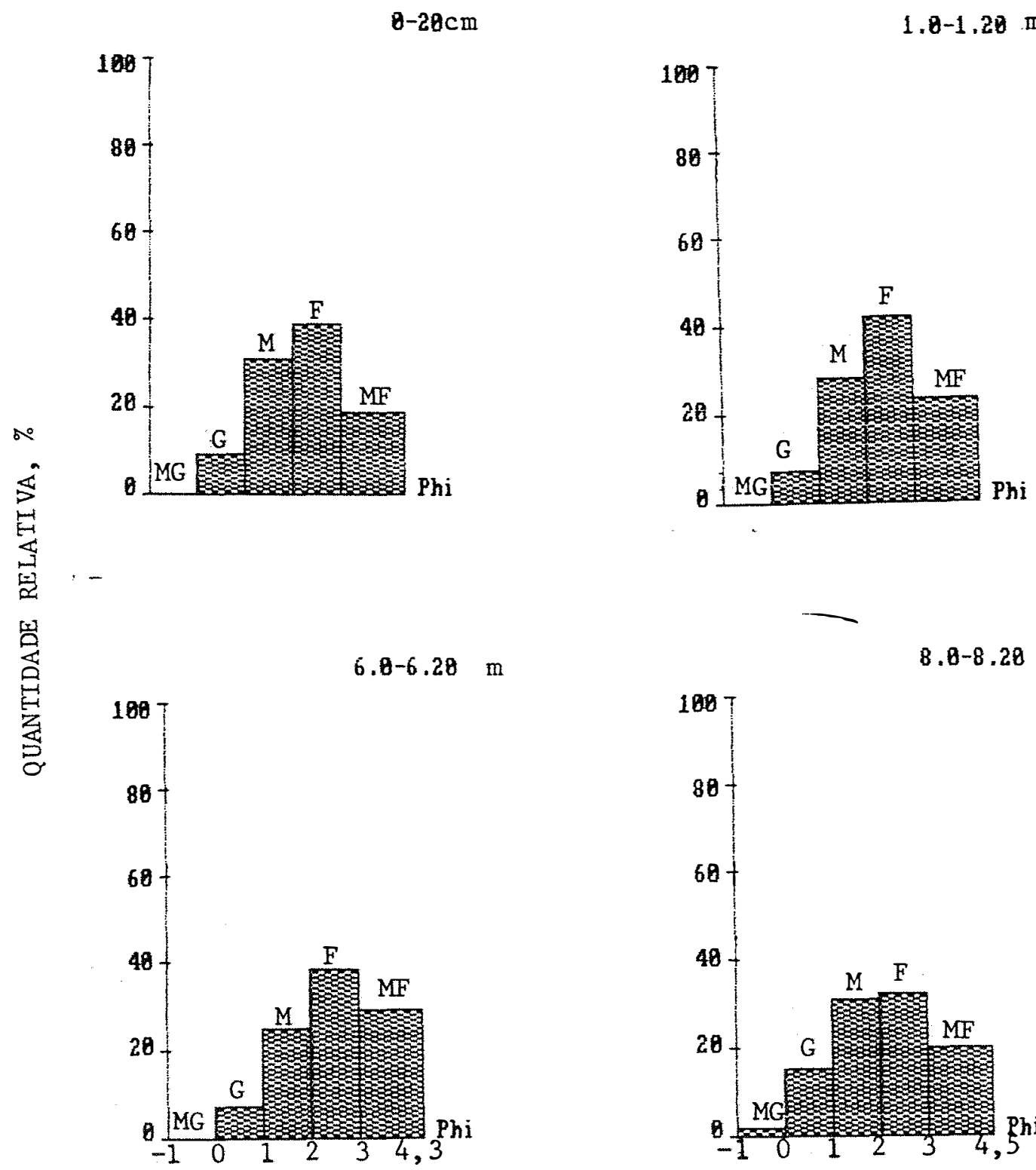

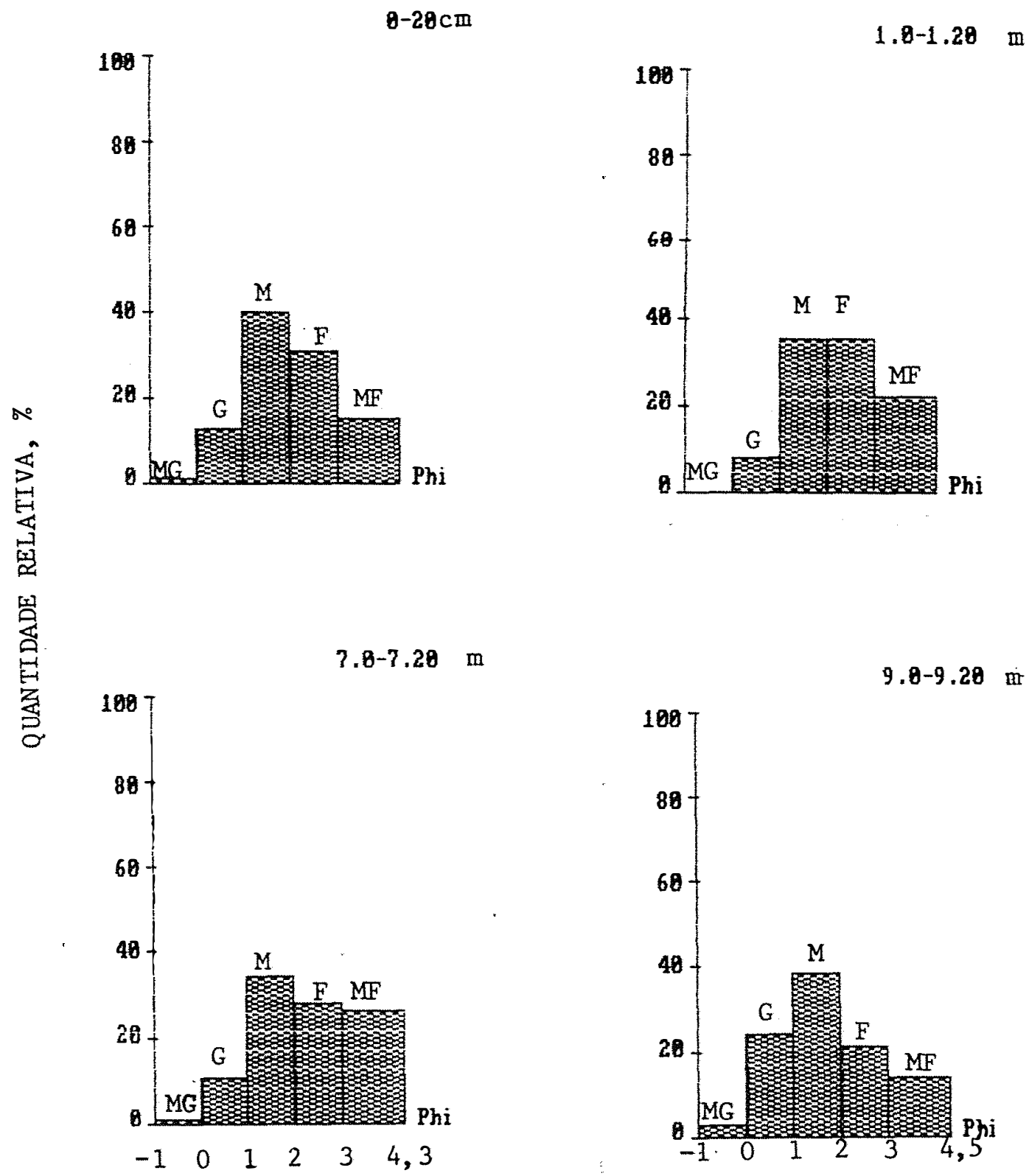

TAMANHO DE PARTICULA, Phi.

FIGURA 13. Histogramas da distribuição de partículas em cinco classes granulométricas de areia (MG: areia muito grossa; $G$ : areia grossa; $M$ : areia média; $F$ : areia fina; MF: areia muito fina) em quatro profundidades selecionadas, da terceira amostragem profunda. 
A explicação de MANZINI (1990) para adequar o modelo estrutural da região à moderna tectônica de Monte Alto,SP, também discutido por PENTEADO \& RANZANI (1971), quando somado ao modelo de BIGARELLA \& ANDRADE (1965) e LEPSCH (1975), fornecem uma contribuição importante ao entendimento da origem dos depósitos cenozóicos na região (FIGURA 14).

Assim, segundo o modelo de MANZINI (1990), nos blocos rebaixados, "grabens", e soerguidos, "horsts", atuaram forças secundárias compressivas dentro do amplo movimento extensional, em que podem ser localizados "horsts" secundários no interior de "grabens", como mostrado na Figura 4 para explicar a situação de Monte Alto. Esta está localizada em um "horst", que por sua vez está, regionalmente, localizado em um amplo "graben". As demais situações estruturais existentes ao longo desta mesma seção são também explicadas dentro do mesmo modelo.

Esta explicação é aqui incluída para adequar o modelo estrutural encontrado à moderna tectônica aplicada às bacias sedimentares, fugindo-se da antiga demonstração de blocos soerguidos e rebaixados, separados por linhas de falhas verticais, em esquemas bastante simplistas.

Neste contexto, observa-se que os blocos rebaixados, "grabens", (FIGURA 14, posição (b)), podem ter favorecido o carreamento de materiais para o seu interior, formando assim um depósito colúvio-aluvionar, sobre a formação Marília, ficando esta área assim preservada da ampla erosão regional devido as condições de alta permeabilidade, e portanto resistência à erosão, do depósito sobre a formação Marília. Estas observações são importantes para explicar o ocorrência de solos altamente intemperizados nas posições mais elevadas da área em estudo.

A identificação dos depósitos cenozóicos no Planalto Ocidental, são muito importantes, uma vêz que indica áreas onde se espera a ocorrência de solos que contrastam com os originados diretamente sobre rochas do grupo Bauru. 


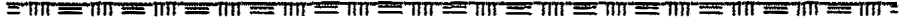

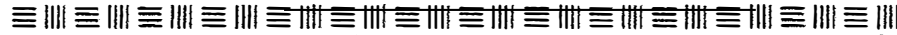

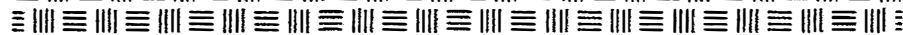

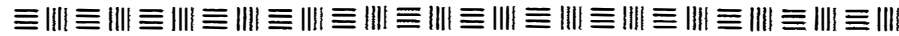

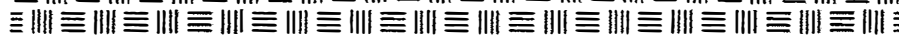

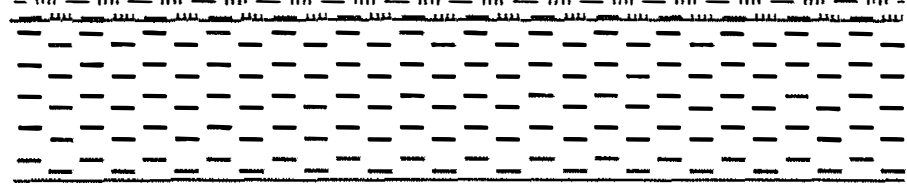

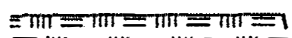

r $=7 m \equiv \pi m \equiv \pi m=n \pi$

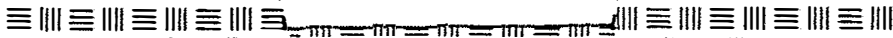

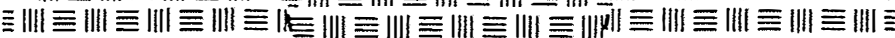

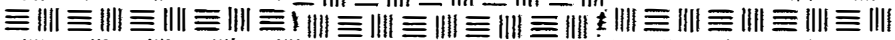

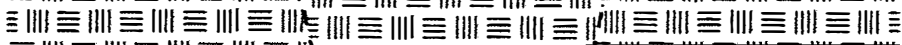

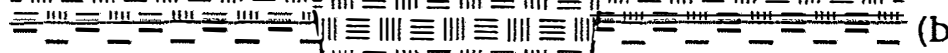

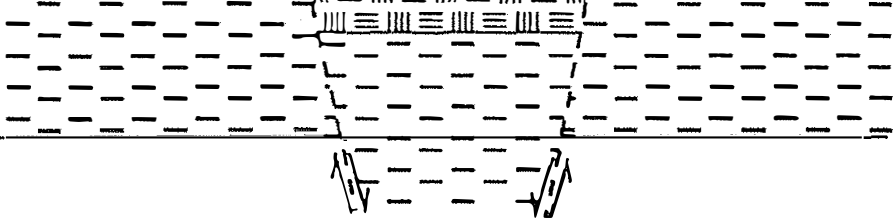

EIIII $\mathrm{Km} \quad E \mathrm{Ka}$

FIGURA 14. Modelo da evolução inicial da paisagem a partir da com origem dos eventos neo-tectônicos, $a=$ formações Adamantina e Marilia, $b=$ após ocorrência de eventos neo-tectônicos (MANZINI, 1990). 


\subsection{Solos da área de estudo}

\subsubsection{Avaliação das propriedades químicas e físicas das unidades de} mapeamento

Na Figura 15 é mostrado o mapa de solos da área e no Quadro 3 a distribuição percentual das unidades encontradas. Este mapa informa que os solos predominantes na área pertencem ao grupamento dos podzólicos, com maiores porcentagens para as unidades PV-2 (35,5\%) e PV-4 (16,8\%). Eles somam mais da metade dos solos que ocorrem na área e coincidem com as duas classes de declive predominantes (2-5\% e 5-10\% respectivamente) (FIGURA 9). Estas unidades de mapeamento de solo estão muito associadas na paisagem às áreas mapeadas como ombro da escarpa (superficie III) e encosta da superficie II, também as de maior ocorrência. No QUADRO 4 são apresentadas as associações entre superficies geomórficas, segmentos de vertente e solos de ocorrência na área.

A unidade de solo com a segunda maior área de ocorrência (PV-4) apresenta solos com elevada erodibilidade.

Os solos podzólicos, em grande parte com mudança textural abrupta, possuem propriedades típicas do agrupamento: têm estrutura em blocos no horizonte $B$, cujos agregados possuem cerosidade. A unidade PV-1 é intensamente manejada com cultura de cebola e milho, e com poucas preocupações conservacionistas; apresenta o horizonte A ou $\mathrm{A}+\mathrm{E}$ relativamente pouco espessos.

A análise dos perfis das unidades PV-2 e PV-3, registra que estes podzólicos são eutróficos, (APÊNDICE 2, Perfis 3, 4 e FIGURA 19), sendo que o PV-2 apresenta baixo grau de saturação por alumínio nos horizontes $\mathrm{A} 2, \mathrm{E}, \mathrm{AB}$ e $\mathrm{Btl}$, e delta $\mathrm{pH}$ positivo na profundidade de 205 a $285 \mathrm{~cm}$ (amostras obtidas com trado tipo holandês no fundo da trincheira). $\mathrm{O}$ valor $\mathrm{Ki}$ destas unidades está bastante próximo entre elas, e dos latossolos (APÊNDICE 2), podendo ser considerados como solos cauliníticos (EMBRAPA 1988 e OLIVEIRA et al., 1992). A CTC da argila calculada com desconto de carbono orgânico (EMBRAPA, 1988), para estes solos (FIGURA 18), apresenta-se baixa, para ambos 


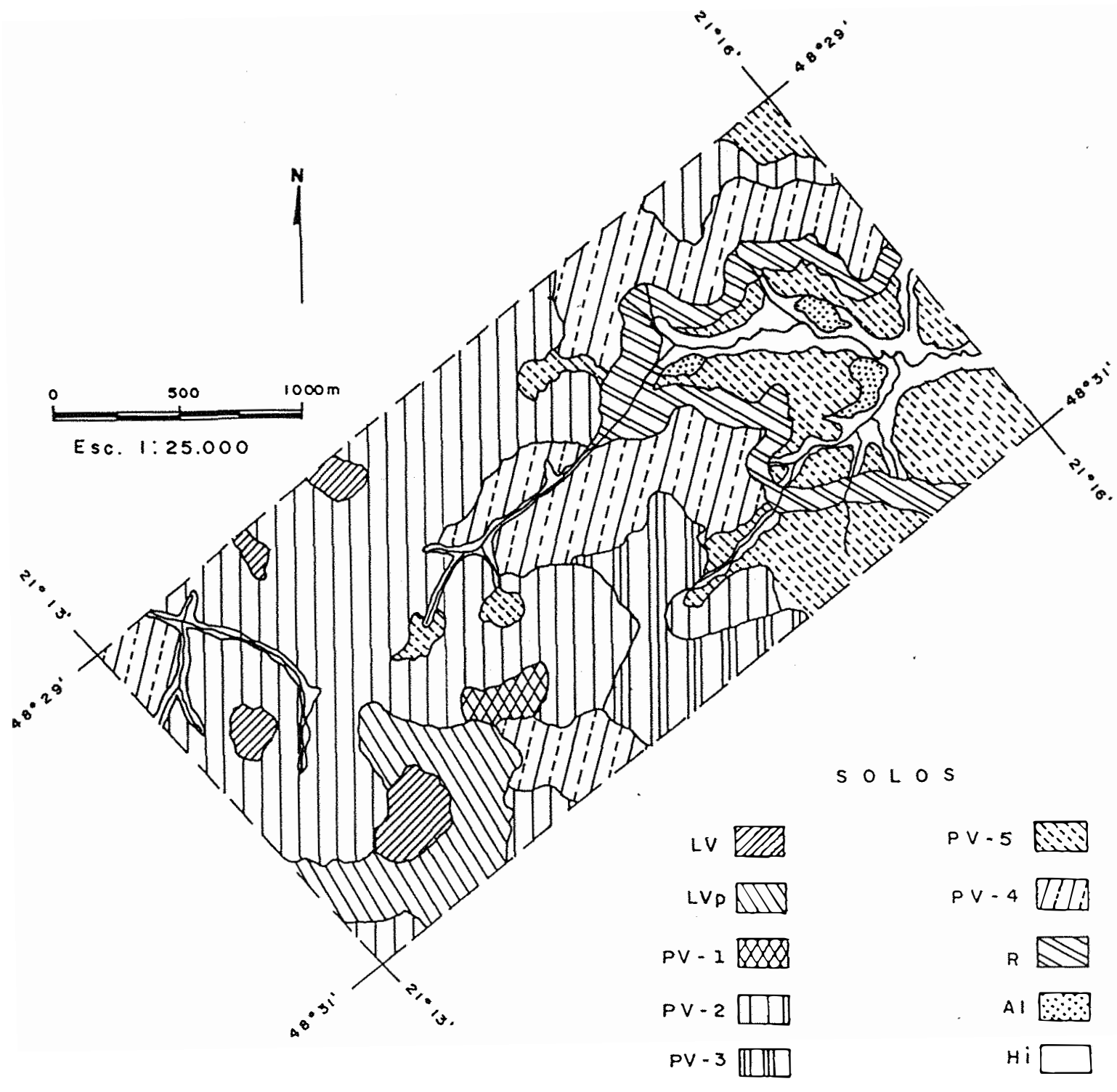

FIGURA 15. Mapa de solos semi-detalhado da área em estudo. 


\section{LEGENDA DAS UNIDADES DE MAPEAMENTO DE SOLOS DA ÁREA}

LV - Latossolo Vermelho-Amarelo Distrófico A moderado textura média relevo plano.

Lvp - Latossolo Vermelho-Amarelo podzólico Distrófico A moderado textura média relevo suave ondulado.

PV-1 - Podzólico Vermelho-Amarelo Eutrófico Tb fase erodida.

PV-2 - PodzólicoVermelho-Amarelo Endoeutrófico Tb abrupto A moderado textura arenosa/média relevo suave ondulado.

PV-3 - PodzólicoVermelho-Amarelo Eutrófico Tb abruptoA moderado textura arenosal média relevo suave ondulado.

PV-4 - PodzólicoVermelho-Amarelo Endoeutrófico Tb abrupto A moderado textura arenosa/ média relevo suave ondulado + Podzólico Vermelho-Amarelo Eutrófico Tb abrupto A moderado textura arenosa/média relevo ondulado.

PV-5 - Podzólico Vermelho-Amarelo Eutrófico Tb abrupto A moderado textura arenosa/ média relevo ondulado + Brunizém textura média relevo suave ondulado.

R - Solo Litólico Eutrófico A moderado textura média + Cambissolo Eutrófico A moderado textura média.

A - Solo Aluvial eutrófico.

G - Solos Gleizados indiscriminados (Glei Húmico e Glei Pouco Húmico). 
horizontes estudados, apresentando valores também muito próximos dos latossolos. A CTC da fração argila também foi calculada pelo método gráfico de BENNEMA (1966), (APÊNDICE 7). Os resultados corroboram com os baixos valores obtidos anteriormente. $O$ método gráfico, mesmo tendo sido elaborado para ser utilizado para latossolos, apresenta bons resultados quando aplicados para os podzólicos da superficie II (PV-1, PV-2 e PV-3), utilizando os dados dos horizontes expostos na trincheira mais aqueles obtidos à partir das tradagens no fundo das trincheiras. Isto é confirmado pelos valôres de $r^{2}$ obtidos pelas regressões (APÊNDICE 7). Baseados nestes resultados pode-se inferir que esses podzólicos que ocorrem na superficie $I$ foram, possivelmente, submetidos aos mesmos processos de formação e possuem o mesmo grau de desenvolvimento, portanto tempo-dependentes da formação desta superficie plio-pleistocênica. Esta é mais jovem, mas seria de idade próxima à superficie I, onde ocorrem os latossolos distróficos.

QUADRO 3. Freqüência de ocorrência e área das unidades de mapeamento de solos.

\begin{tabular}{|c|c|c|}
\hline Unidade de Mapeamento & Área (ha) & \% Area Total \\
\hline LV & 23,5 & 3,8 \\
LVp & 45,3 & 7,4 \\
PV-1 & 7,8 & 1,3 \\
PV-2 & 217,2 & 35,5 \\
PV-3 & 39,0 & 6,4 \\
PV-4 & 103,1 & 16,8 \\
PV-5 & 79,7 & 13,0 \\
R & 46,9 & 7,7 \\
A & 9,4 & 1,5 \\
G & 40,6 & 6,6 \\
\hline
\end{tabular}

Área Total $=612,5$ ha.

A unidade PV-3, em áreas com declives mais suaves, apresenta os horizontes $\mathrm{A}+\mathrm{E}$ relativamente espessos, e manifestação mais intensa da cerosidade no horizonte $\mathrm{B}$ (APÊNDICE 2, Perfil 4). Está associada a um provável pretérito sopé de deposição situado dentro da superficie II (FIGURA 10). 
QUADRO 4. Superficie geomórfica, segmentos de vertente e solo de ocorrência.

\begin{tabular}{|c|c|}
\hline $\begin{array}{l}\text { SUPERFÍCIE GEOMÓRFICA E } \\
\text { SEGMENTO DE VERTENTE }\end{array}$ & SOLOS DE OCORRÊNCIA \\
\hline $\begin{array}{l}\text { I Topo quase plano (A) } \\
\text { II Encosta } \\
\text { Ombro } \\
\text { Superior (B) } \\
\text { Inferior (C) } \\
\text { Sopé (D) } \\
\text { Superficie de deposição pretérita } \\
\text { III Ombro (E) } \\
\text { Escarpa (F) } \\
\text { Sopé de transporte (G) } \\
\text { Sopé de deposição (H) } \\
\text { Declive aluvial (I) }\end{array}$ & $\begin{array}{l}\text { Latossolo Vermelho-Amarelo } \\
\text { Podzólico (LVp) } \\
\text { Podzólico Vermelho-Amarelo (PV-1) } \\
\text { Podzólico Vermelho-Amarelo (PV-2 e } \\
\text { PV-3) } \\
\text { Podzólico Vermelho-Amarelo (PV-4) } \\
\text { Solos Litólicos e Cambissolos (Li e C) } \\
\text { Cambissolo e PV-4 } \\
\text { Brunizém (B) e PV-5 } \\
\text { Aluvial e Gleizado (A + G) }\end{array}$ \\
\hline
\end{tabular}

A unidade dos PV-4 aparece em sua maior parte, associada a brunizéns e em uma menor parte ao PV-2. O PV-4 está situado no ombro da escarpa, com declives mais acentuado. Os resultados das análises do perfil (APÊNDICE 2, Perfil 5) e das unidades de mapeamento (FIGURA 19), revelam que estes podzólicos são eutróficos, apresentando valores $\mathrm{Ki}$ (APÊNDICE 2, Perfil 5) e CTC da argila (FIGURA 18) mais elevados relativamente aos demais podzólicos. Salienta-se que entre os podzólicos estudados, o PV-4 é o único que apresenta valor $\mathrm{Ki}$ acima de 2,2, que é o limite superior reconhecido para latossolos (EMBRAPA, 1988). Os valores da CTC da argila pelo método gráfico também apresenta-se superior para estes podzólicos (APÊNDICE 7). As mudanças na morfoscopia e mineralogia (APÊNDICE 4 e 5) destes podzólicos registra seu comportamento diferencial dos demais podzólicos que ocorrem na superficie II.

Os brunizéns ocorrem nas cotas mais baixas da paisagem, e estão associados à locais de intensa deposição e erosão, em sequência à escarpa, posições estas inseridas na 
superficie III. Estes solos, de alta fertilidade natural, situados nas posições de sopé de deposição (FIGURA 10 e QUADRO 4), apresentam valores mais elevados de Ki e de CTC da argila (pelo método gráfico) indicando a presença de argila de atividade alta $(43 \mathrm{cmol} / \mathrm{kg}$ ) (APÊNDICE 2, Perfil 7 e APÊNDICE 7), corroborando com seus elevados teores de soma de bases. Estes solos apresentam textura média no horizonte B, discordando de OLIVEIRA et al. (1992), quando citam a ocorrência de brunizéns no Brasil invariavelmente com horizonte B de textura argilosa.

Com fertilidade natural muito próxima aos brunizéns, porém associados à origem mais carbonática do arenito da formação Marilia, os cambissolos, associados aos solos litólicos, ocorrêm na escarpa e sopé de transporte (FIGURAS 10, 15 e QUADRO 4).

Os latossolos, mapeados nas unidades LV e LVp, ocorrem em pequenas áreas nas posições mais elevadas. Estes são formados a partir dos depósitos superficiais sobre os quais foi mapeada a superficie mais antiga. Segundo Ab'SABER (1969), esses topos anteriormente coalescentes por pediplanação, são testemunhos de uma paisagem de elaboração pós-pliocênica.

Estes solos apesar de se enquadrarem nos latossolos vermelho-amarelos tem características próximas da classe dos latossolos Vermelho-Escuro, com cor no horizonte B, com matiz 3,5 YR, estrutura granular muito pequena e bem desenvolvida, friável e muito profundos. Nas duas tradagens profundas realizadas ( 9 metros), o matiz altera-se para $10 \mathrm{YR}$ após 6 metros de profundidade. Estas áreas por cerca de 10 a 20 anos, estão sendo intensamente cultivadas com cana-de-açúcar, o que explica o comportamento das propriedades químicas do horizonte Ap $(0-20 \mathrm{~cm})$ que indica enriquecimento com bases devido práticas de calagem e adubação (FIGURAS 18 e 19).

Nas FIGURAS 16 e 17, são apresentados o comportamento do $\mathrm{pH}$ em $\mathrm{H}_{2} \mathrm{O}$ e em $\mathrm{KCl}$, delta $\mathrm{pH}$ e acidez trocável $\left(\mathrm{Al}^{3+}\right)$ das unidades de mapeamento dos solos, à partir de amostras obtidas por tradagens em duas profundidades (0-20 e 60-80 cm), através do teste de comparação de médias (intervalo de confiança a 95\%). Os resultados estatísticos estão no Apêndice 3.

No geral, para todas as unidades de mapeamento, os valores de $\mathrm{pH}$ em água e em $\mathrm{KCl}$ são maiores na profundidade de $0-20 \mathrm{~cm}$, em relação à profundidade de $60-80 \mathrm{~cm}$, 

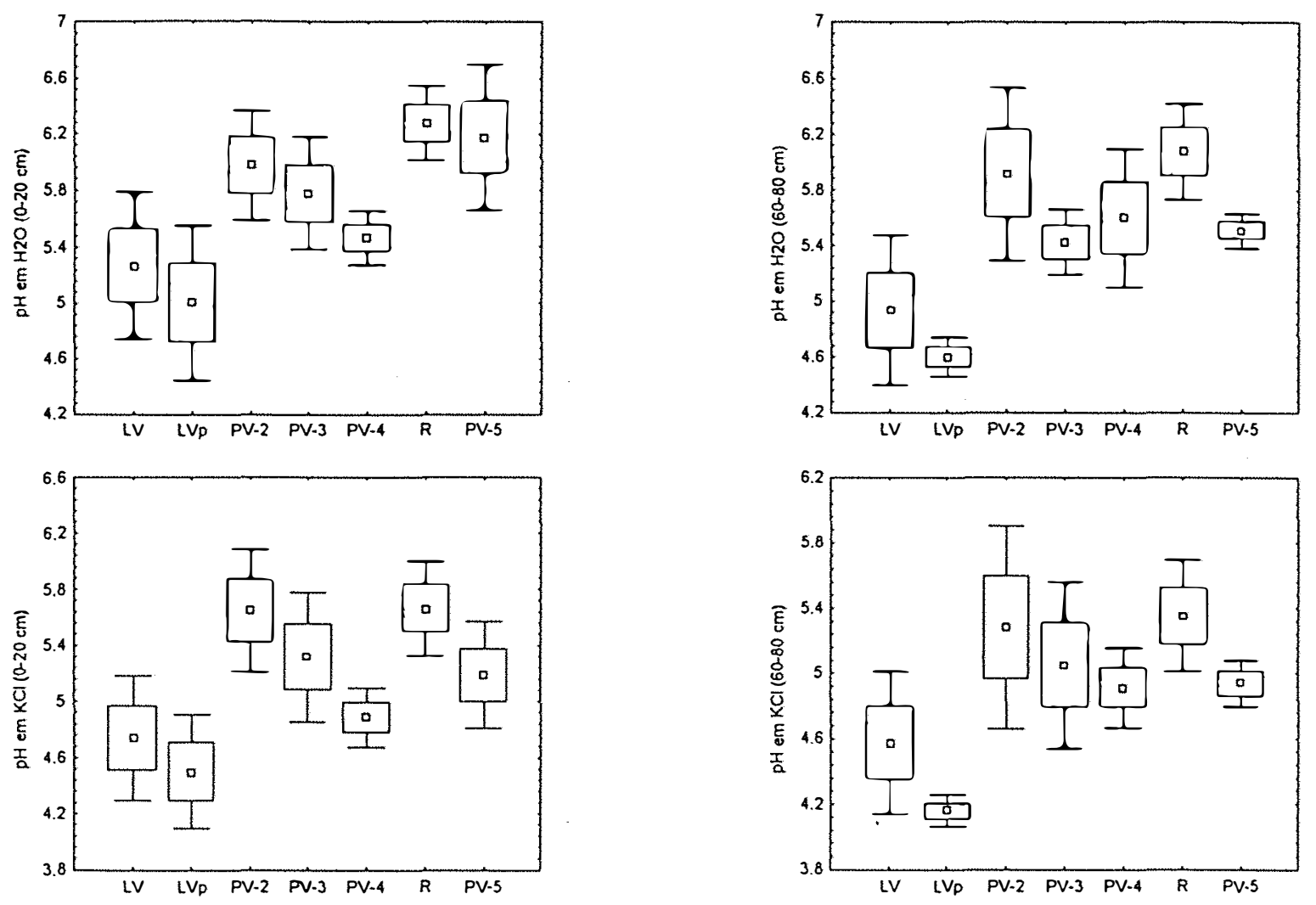

FIGURA 16.Médias (quadrado pequeno) com respectivos intervalos de confiança (média \pm $\mathrm{S} \overline{\mathrm{x}}$ e média $\pm 1,96 \mathrm{~S} \overline{\mathrm{x}})$ do $\mathrm{pH}$ em $\mathrm{H}_{2} \mathrm{O}$ e $\mathrm{KCl}$ das unidades de mapeamento. 

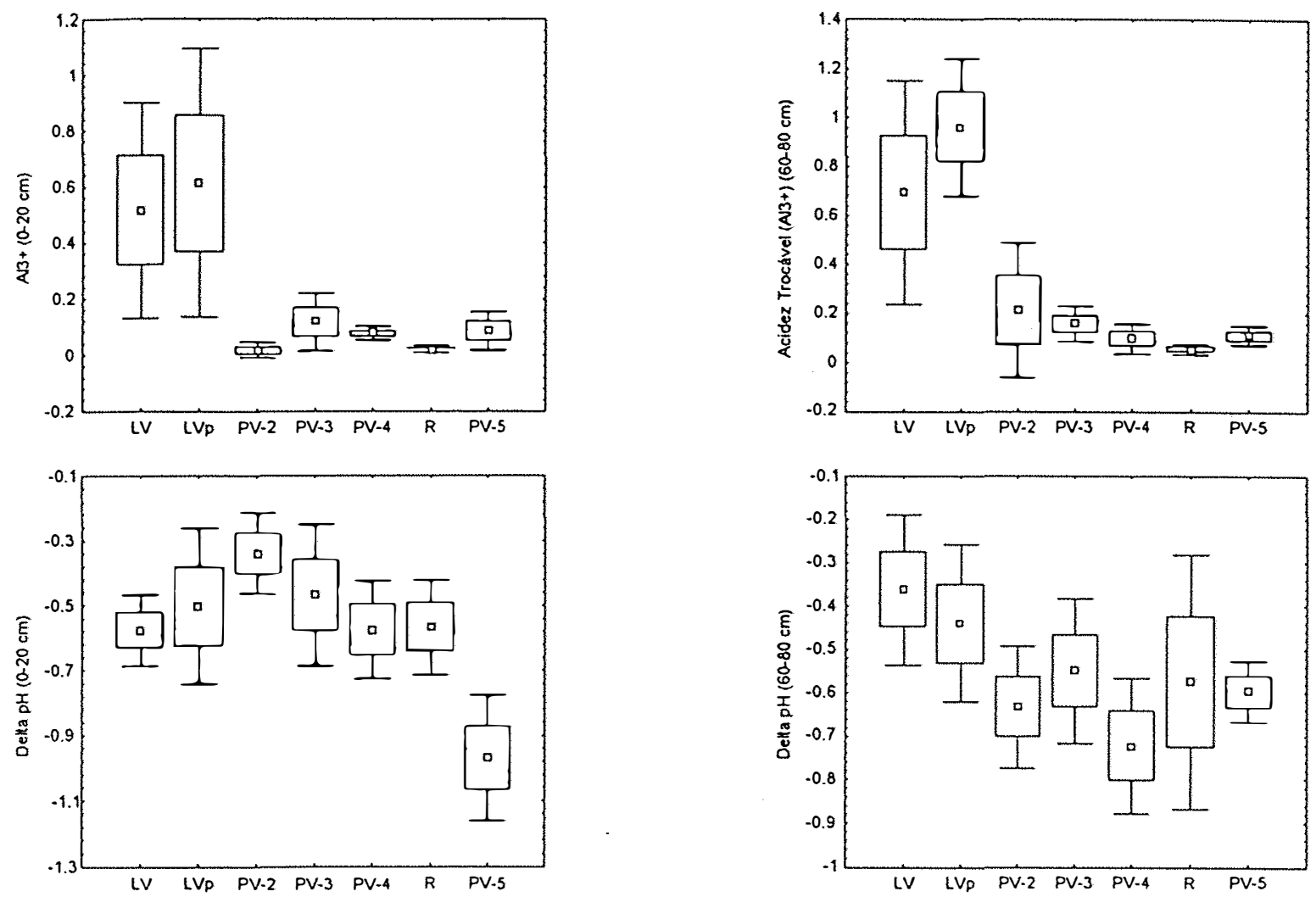

FIGURA 17. Médias (quadrado pequeno) com respectivos intervalos de confiança (média \pm $\mathrm{S} \bar{x}$ e média $\pm 1,96 \mathrm{~S} \bar{x})$ da acidez trocável e $\mathrm{DpH}$ das unidades de mapeamento. 
exceto para a unidade PV-4, que possui o horizonte A relativamente mais erodido, o que também justifica seus respectivos maiores intervalos de confiança (Apêndice 3). Os maiores valores médios de $\mathrm{pH}$ coincidem com os solos menos espessos, que possivelmente são os que estão sendo mais rapidamente rejuvenescidos.

Os menores valores médios de $\mathrm{pH}$ em $\mathrm{H}_{2} \mathrm{O}$ e em $\mathrm{KCl}$, pertencem às unidades que incluem os latossolos, diferindo significativamente das demais unidades. Estes resultados mostram que estes são os solos mais lixiviados e que os minerais de argila presentes podem desenvolver mais cargas positivas por dissociação ou adsorção de prótons, estando este fenômeno associado à atividade do íon hidrogênio na solução do solo (KENG \& UEHARA, 1974; TAN, 1982).

A formação e a solubilização de argilas, deve estar liberando alumínio para solução do solo (LINDSAY, 1979), conforme pode-se observar pelas médias mais elevadas do $\mathrm{Al}^{3+}$ destes solos (FIGURA 17).

Os valores de $\mathrm{pH}$ em $\mathrm{KCl}$ são menores do que aqueles de $\mathrm{pH}$ em $\mathrm{H}_{2} \mathrm{O}$ para ambos horizontes amostrados e em todas as unidades de mapeamento, condicionando um delta $\mathrm{pH}$ negativo (FIGURA 17), indicando um domínio de cargas elétricas negativas (RAU e PEECH, 1972 e RAIJ, 1973). Os maiores valores médios de delta $\mathrm{pH}$ dos latossolos (na profundidade 60-80 cm), associados aos seus baixos teores em bases (FIGURAS 17 e 1), refletem a maior pobreza do seu material de origem (associado ao depósito neocenozóico), e 0 intenso e longo processo de intemperismo-lixiviação aos quais estes solos foram submetidos, condicionando um enriquecimento relativo de óxidos de ferro e de alumínio (MARQUES JÚNIOR et al., 1992).

A baixa atividade da argila (FIGURA 18) é coerente com a classificação destes solos como latossolos (< $13 \mathrm{cmol} . / \mathrm{kg}$ ) (EMBRAPA, 1988). As médias de delta $\mathrm{pH}$ mais negativo pertencem às unidades PV-5 $(0-20 \mathrm{~cm})$, e PV-4 $(60-80 \mathrm{~cm})$, indicando a presença de argilas mais ativas.

Os latossolos são distróficos (FIGURA 19), apresentando V\% pouco maior na profundidade $0-20 \mathrm{~cm}$, pelo efeito do manejo, ou reciclagem vegetal pela incorporação de nutrientes devido a decomposição de matéria orgânica, e liberação de bases. Os demais solos são eutróficos, com destaque para os cambissolos, podzólicos do ombro (superficie III) e 

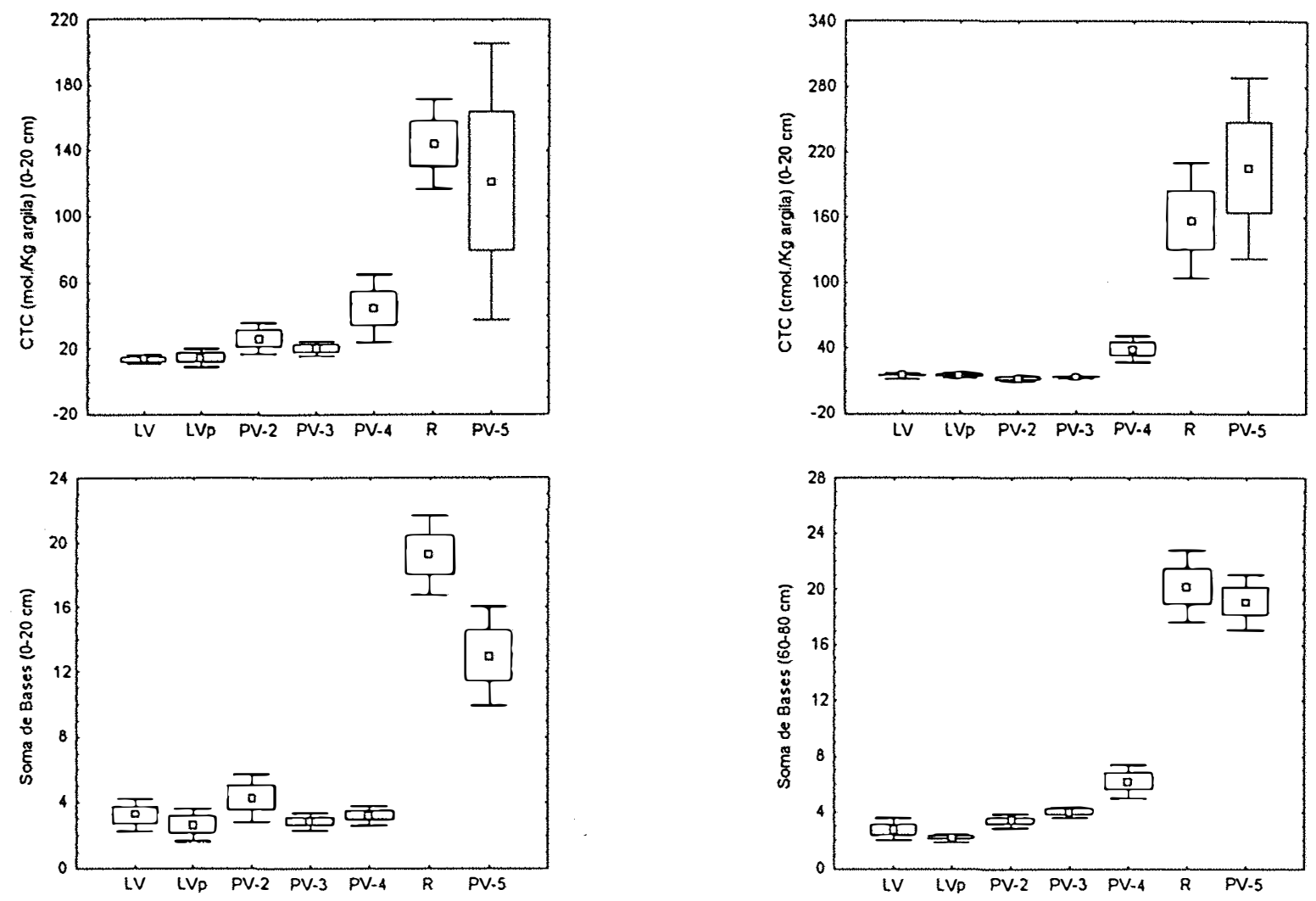

FIGURA 18. Médias (quadrado pequeno) com respectivos intervalos de confiança (média \pm $\mathrm{S} \overline{\mathrm{x}}$ e média $\pm 1,96 \mathrm{~S} x)$ da somas de bases e CTC da argila das unidades de mapeamento. 

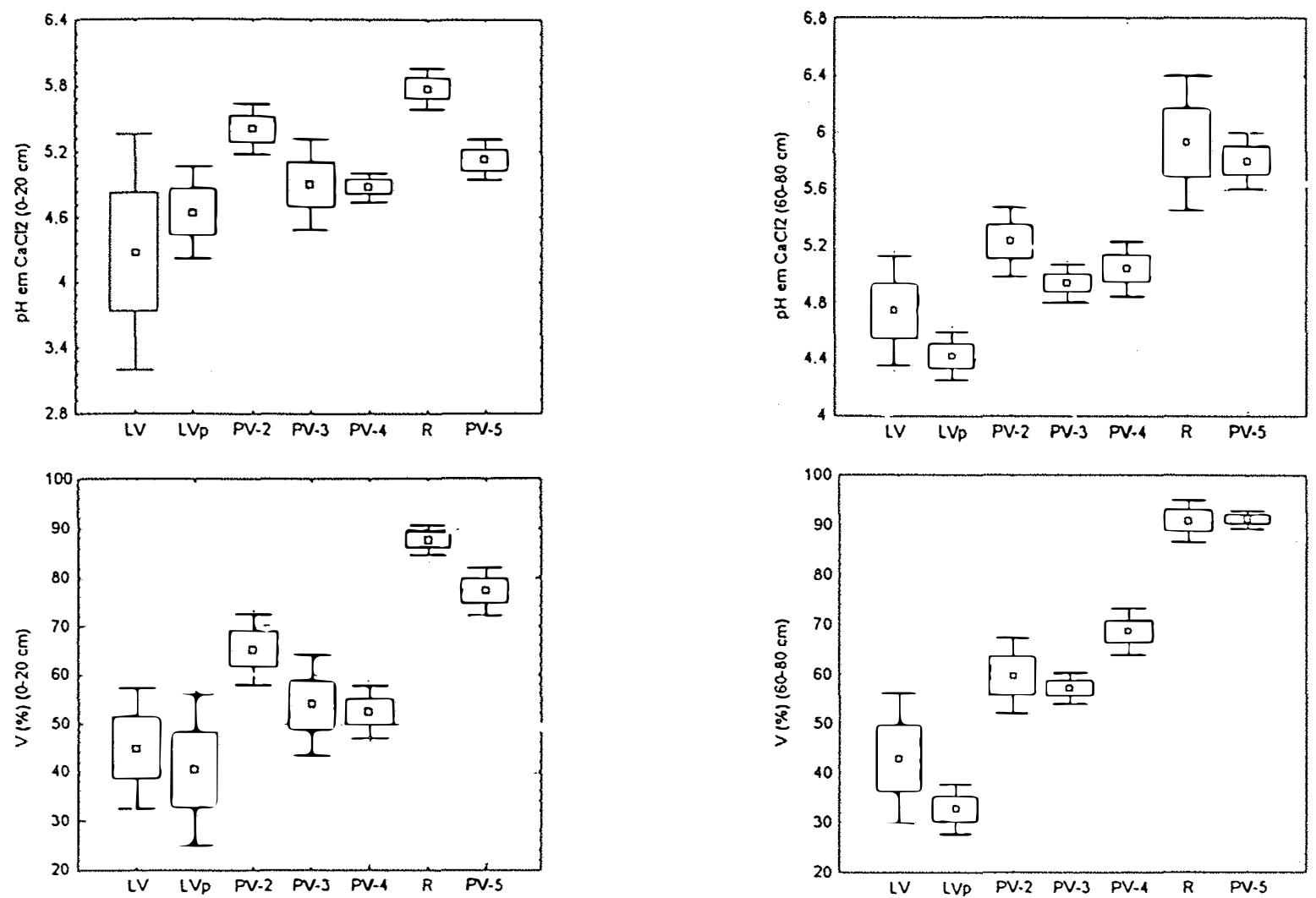

FIGURA 19. Médias (quadrado pequeno) com respectivos intervalos de confiança (média \pm $\mathrm{S} \overline{\mathrm{x}}$ e média $\pm 1,96 \mathrm{~S} \overline{\mathrm{x}}$ ) da saturação por bases e $\mathrm{pH}$ em $\mathrm{CaCl}_{2}$ das unidades de mapeamento. 
brunizéns que apresentam valores de V\% muito elevados devido à proximidade com o arenito carbonatado nos cambissolos e, a posição dos brunizéns no sopé de deposição. A CTC da argila destes dois últimos acompanha a mesma tendência, indicando a presença de argilas de atividade muito elevada (FIGURA 18), confirmando nesta unidade a presença dos brunizéns, o que é reforçado pelo carbono orgânico (FIGURA 20), presente em teores suficientes para caracterizar o horizonte A chernozêmico. O grande intervalo de confiança observado para as médias dos atributos da unidade PV-4, pode ser atribuído boa parte dos pontos sorteados para serem amostrados terem coincidido com locais onde o solo está erodido.

O comportamento dos parâmetros fisicos das unidades estudadas é apresentado através do teste de comparação de médias nas Figuras 20 e 21.

A fração areia fina mostra um domínio sobre a areia grossa nos solos mais rejuvenescidos (R e PV-5), com diferença significativa em relação às outras unidades de solos podzólicos, indicando uma variabilidade na composição textural do material original destes solos.

O comportamento da argila nas duas profundidades informa sobre o caráter abrupto nos solos podzólicos. Os maiores intervalos de confiança na profundidade de 0-20 $\mathrm{cm}$, para todas as unidades, revela a erosão hídrica seletiva. $\mathrm{O}$ mesmo processo pode explicar os menores incrementos de argila na profundidade de $60-80 \mathrm{~cm}$ na unidade PV-4.

Os teores de silte apresentam-se baixos nos latossolos, contribuindo para a diminuição dos valores da relação silte/argila o que reforça sua condição de solo com maior grau de intemperismo. O valor maior que 0,7 para esta relação é registrado somente nos cambissolos.

\subsubsection{Variabilidade dos solos na transeção}

A transeção estudada, percorre o espigão da vertente por extensão de 2.700 m, à partir do topo (765 m de altitude) até o sopé de deposição (600 m), (FIGURA 22).

Observou-se uma tendência geral de valores crescentes de saturação por bases ao longo da transeção para ambas profundidades (FIGURA 23a). Essa tendência sugere a ocorrência de solos distróficos (poucos epieutróficos) nos primeiros 750 metros, e a partir 

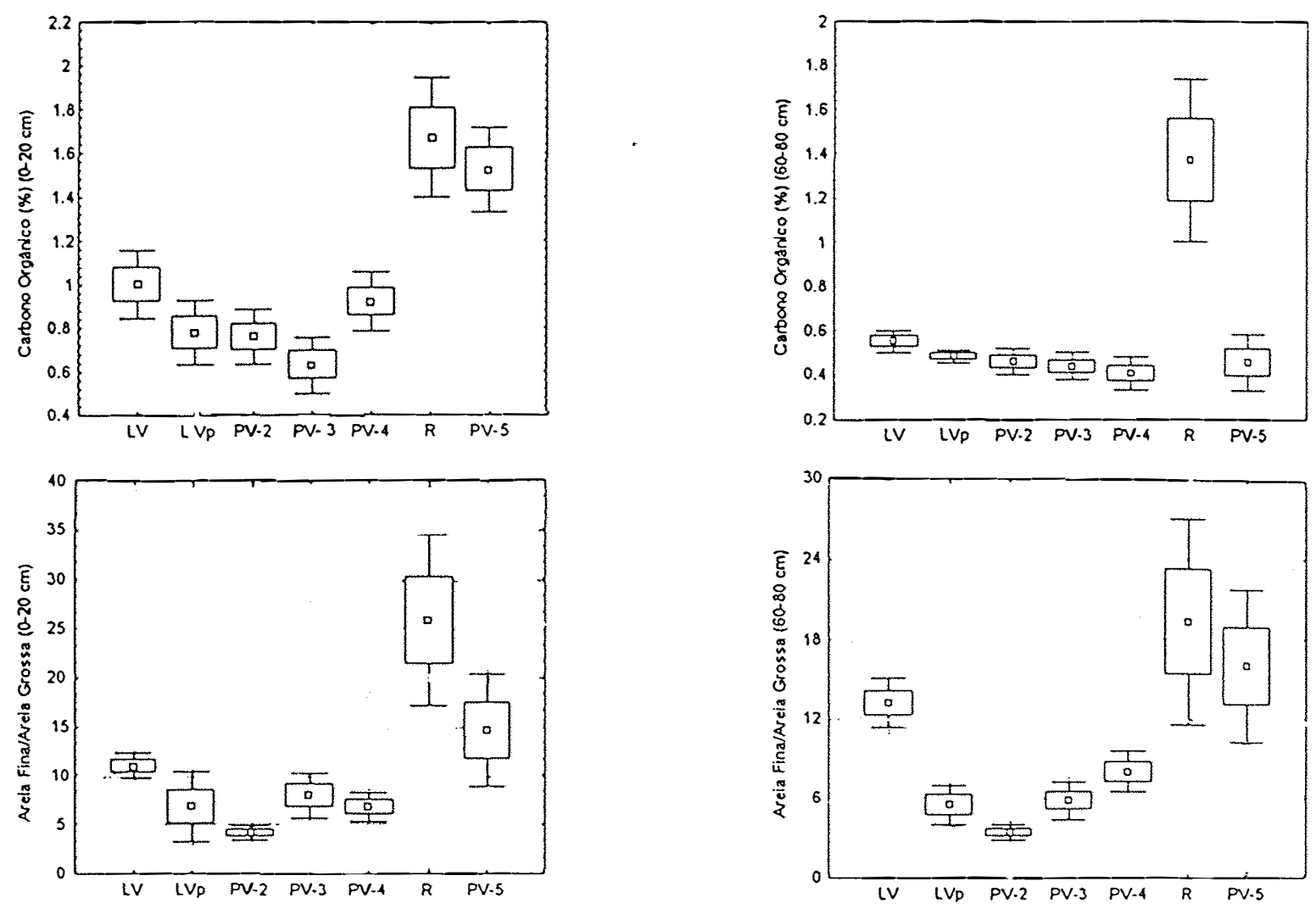

Figura 20. Médias (quadrado pequeno) com respectivos intervalos de confiança (média \pm $S \bar{x}$ e média $\pm 1,96 S \bar{x}$ ) do carbono orgânico e relação areia fina/areia grossa das unidades de mapeamento. 

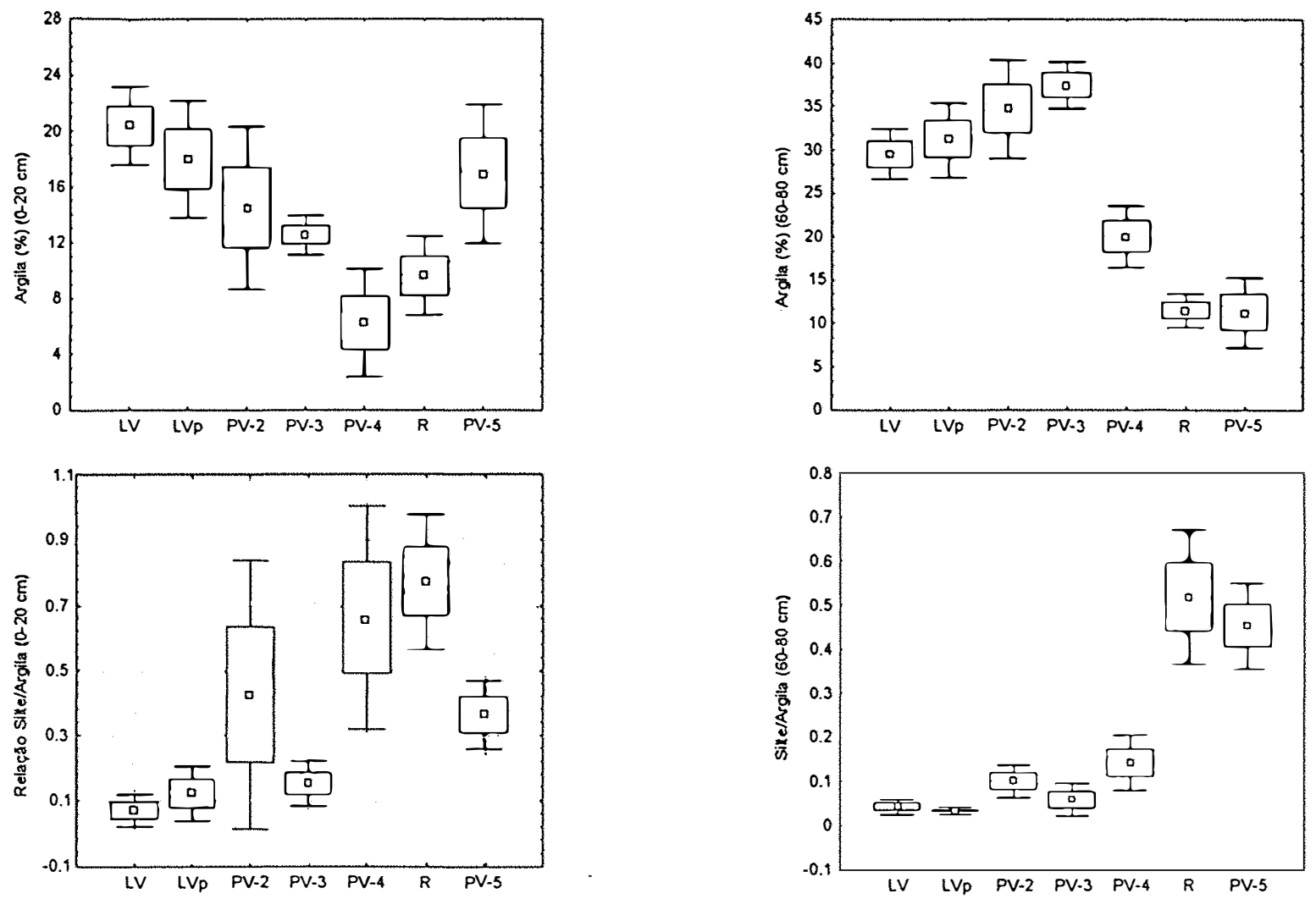

Figura 21. Médias (quadrado pequeno) com respectivos intervalos de confiança (média \pm $\mathrm{S} \overline{\mathrm{x}}$ e média $\pm 1,96 \mathrm{~S} \overline{\mathrm{x}})$ do teor de argila e relação silte/argila das unidades de mapeamento. 


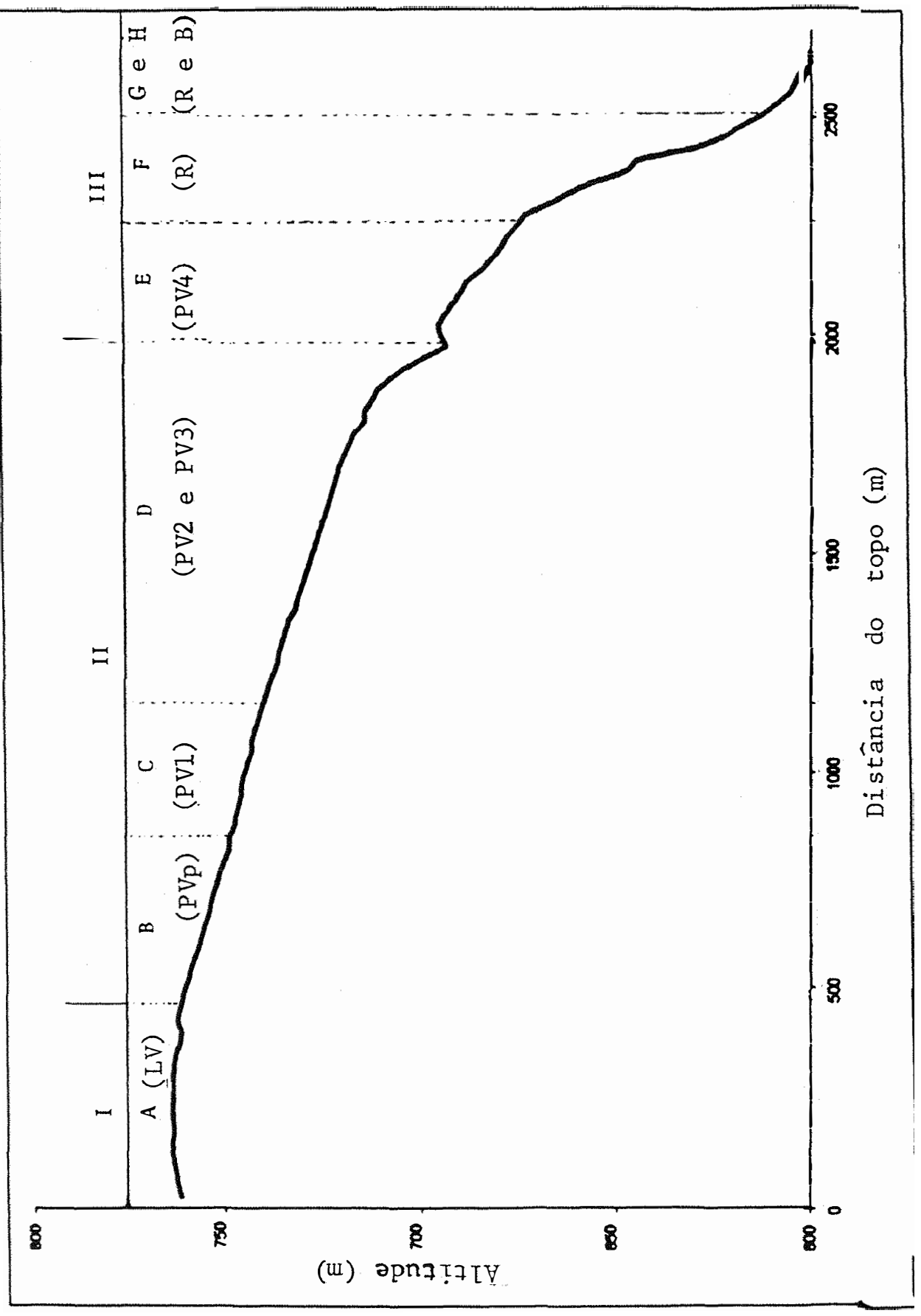

芯

䢘

용

롱 응

응

总 芯

음

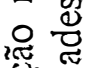

늠

虽

恶 0

刃 劳

잉

恣类

융 용

曹䓵

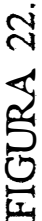



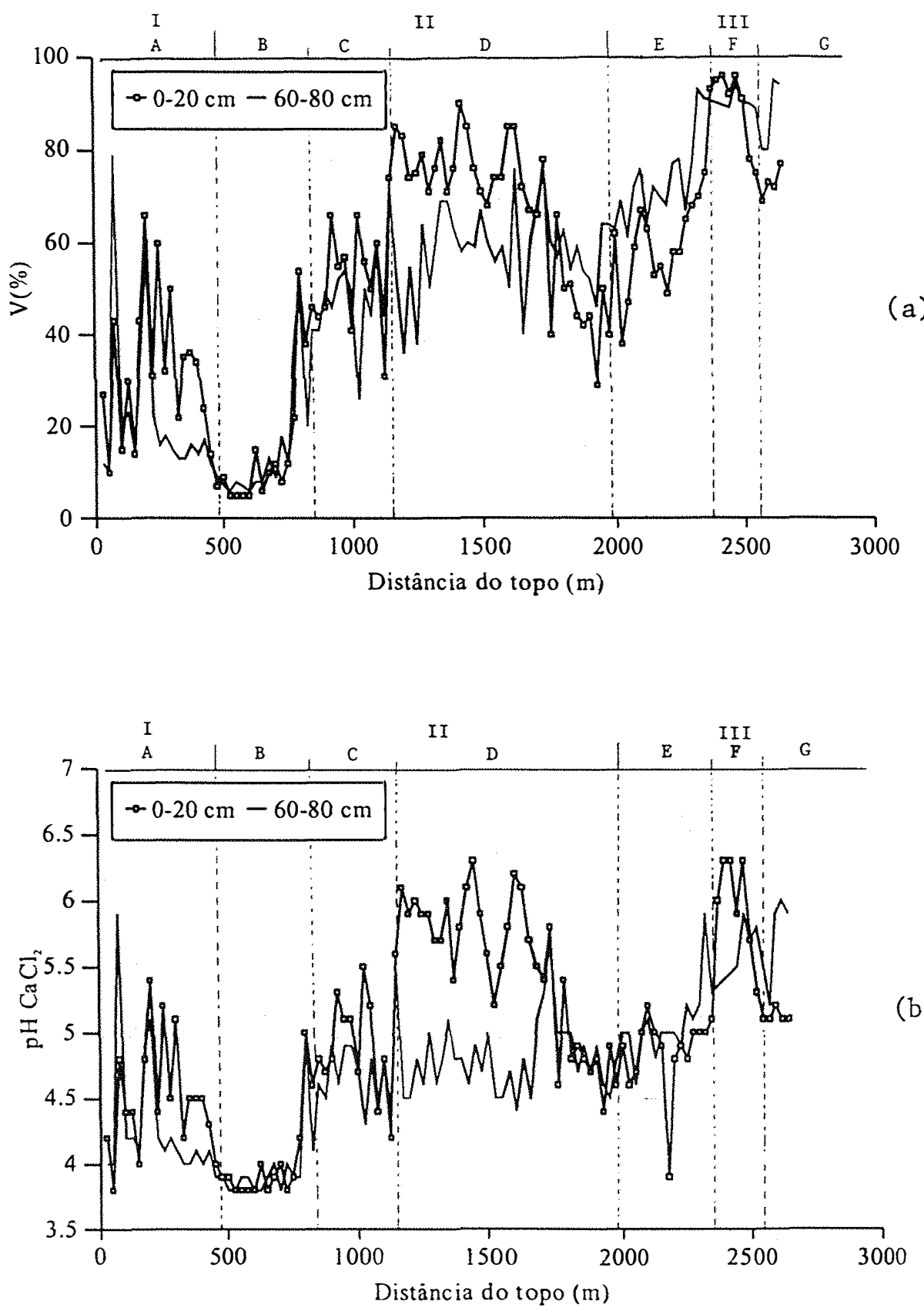

FIGURA 23. Comportamento de atributos do solo, em duas profundidades, ao longo da transeção de acordo com superficies geomórficas (números romanos) e seus segmentos decrescente a) saturação por bases; b) $\mathrm{pH}$ em $\mathrm{CaCl}_{2}$. 
desse ponto, solos com teores crescentes de V\% até o domínio dos eutróficos, sendo que os de mais altos teores ocorrem após 2.250 metros do início da transeção. Os valores de $\mathrm{pH}$ em $\mathrm{CaCl}_{2}$ (FIGURA 23b) acompanham os valores de V\%, confirmando a boa correlação entre esses dois parâmetros.

$\mathrm{O}$ comportamento do $\mathrm{V} \%$ e $\mathrm{pH}$ refletem o enriquecimento em bases ao longo da transeção, indicando ambientes rejuvenescidos à jusante do início da vertente. Para ambos parâmetros, há uma tendência de inversão de teores das profundidades à partir de 1975 metros, devido ao contato com os solos mais rasos, indicando a proximidade do material de origem, arenito arcósico e rico em carbonato de cálcio.

$\mathrm{Na}$ posição A (topo), área de ocorrência dos latossolos, esses parâmentros apresentam valores mais elevados, alguns epieutróficos, por influência do manejo da cana-deaçúcar. Na posição B (ombro da encosta), os valores desses parâmetros apresentam-se muito baixos, típicos dos latossolos. Os valores tendem a aumentar nas posições à juzante do topo da vertente. As maiores diferenças entre as duas profundidades na transeção são registradas na posição $\mathrm{D}$, área de ocorrência dos podzólicos com horizontes $\mathrm{A}+\mathrm{E}$ mais espessos, ficando o horizonte $\mathrm{B}$ mais distante da influência do uso de fertilizantes. No final do segmento $\mathrm{D}$, limítrofe para $\mathrm{E}$, bem como no início do segmento $\mathrm{B}$, os valores de $\mathrm{pH}$ e $\mathrm{V} \%$ tendem a serem mais baixos devido ao relevo ser mais suavizado nesta posição, o que deve favorecer uma maior taxa de intemperismo-lixiviação.

Observa-se ainda o comportamento diferencial desses parâmentros na superficie III (FIGURA 23a e 23b). São crescentes no ombro (E), atingindo seus maiores valores na escarpa (F) indicando que o ambiente da escarpa condiciona o máximo de rejuvenescimento do solo, com diminuição desses valores no sopé de transporte $(G)$. O mesmo comportamento é observado para a CTC da argila, matéria orgânica e soma de bases (FIGURAS 24a, 24b e 25a) na superficie III. Nas demais superficies esses parâmetros apresentam-se também com um comportamento muito próximo. A soma de bases apresentase com valores muito baixos nos latossolos (exceto no horizonte A dos latossolos do topo), e teores baixos nos podzólicos dos segmentos $C$ e D, aumentando na superficie III. A CTC da argila apresenta-se muito baixa na posição A e, baixa em B e C, para ambos horizontes, tendendo a aumentar em alguns pontos no horizonte $\mathrm{A}$ do segmento $\mathrm{D}$, podendo indicar 

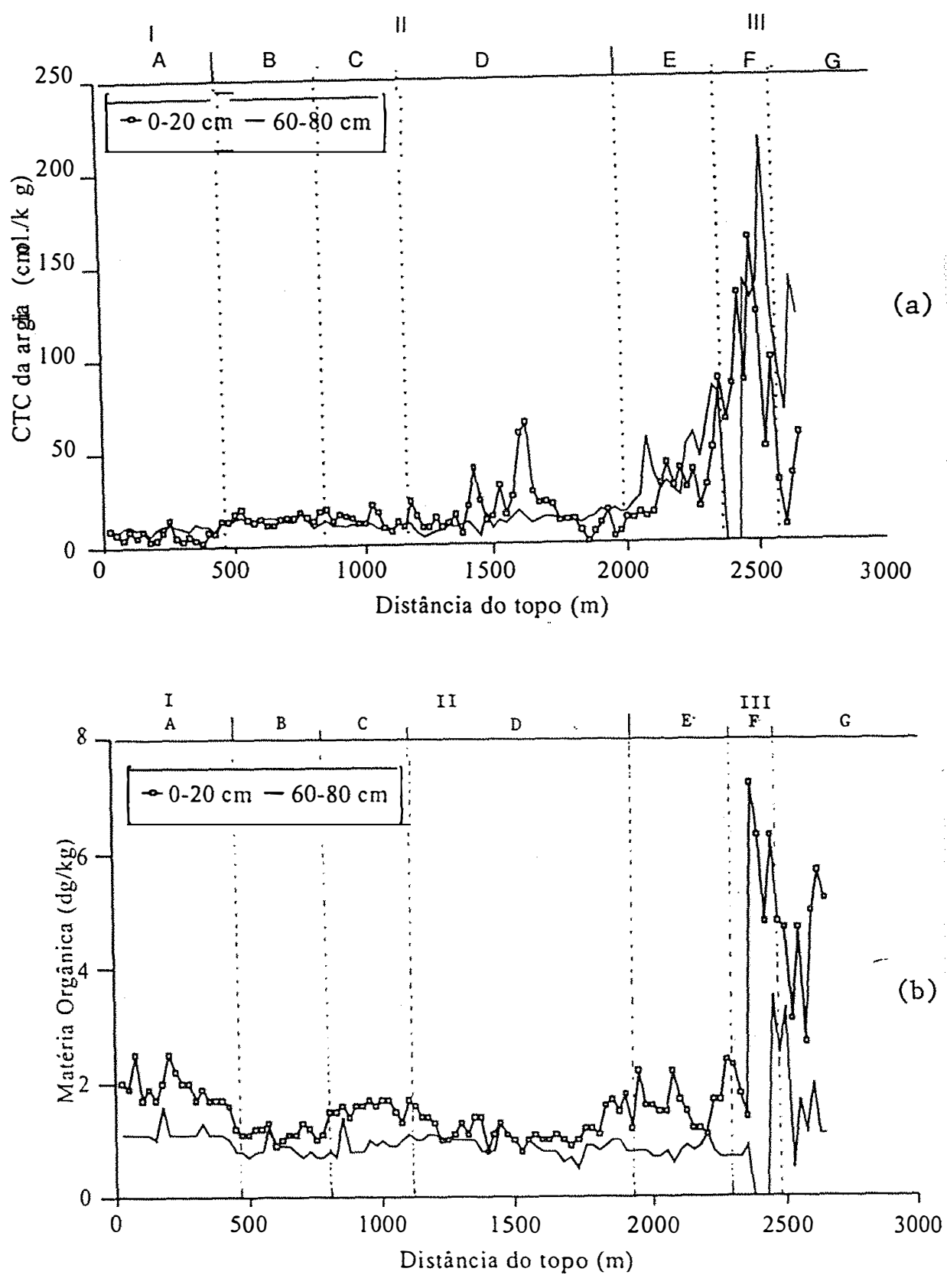

FIGURA 24.Comportamento de atributos do solo, em duas profundidades, ao longo da transeção de acordo com superficies geomórficas (números romanos) e seus segmentos decrescente a) Comportamento da CTC da argila na transeção; b) Comportamento da matéria orgânica na transeção. 


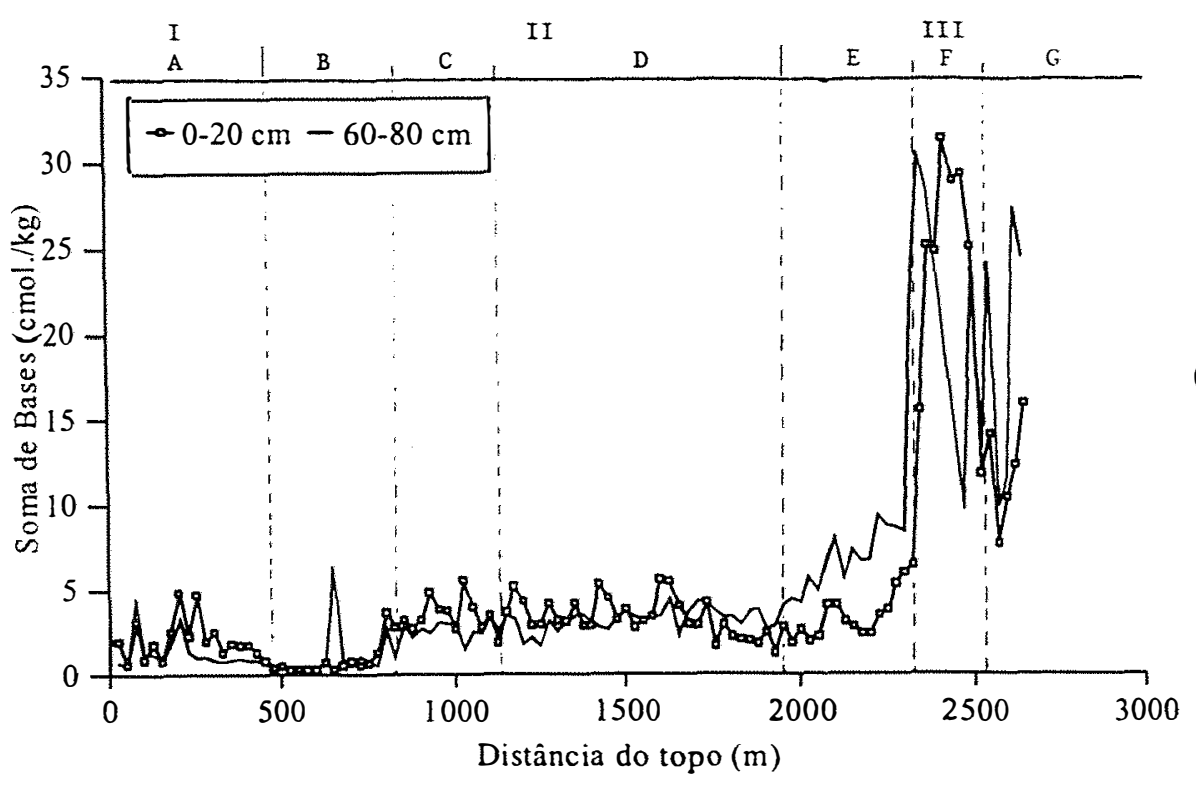

(a)

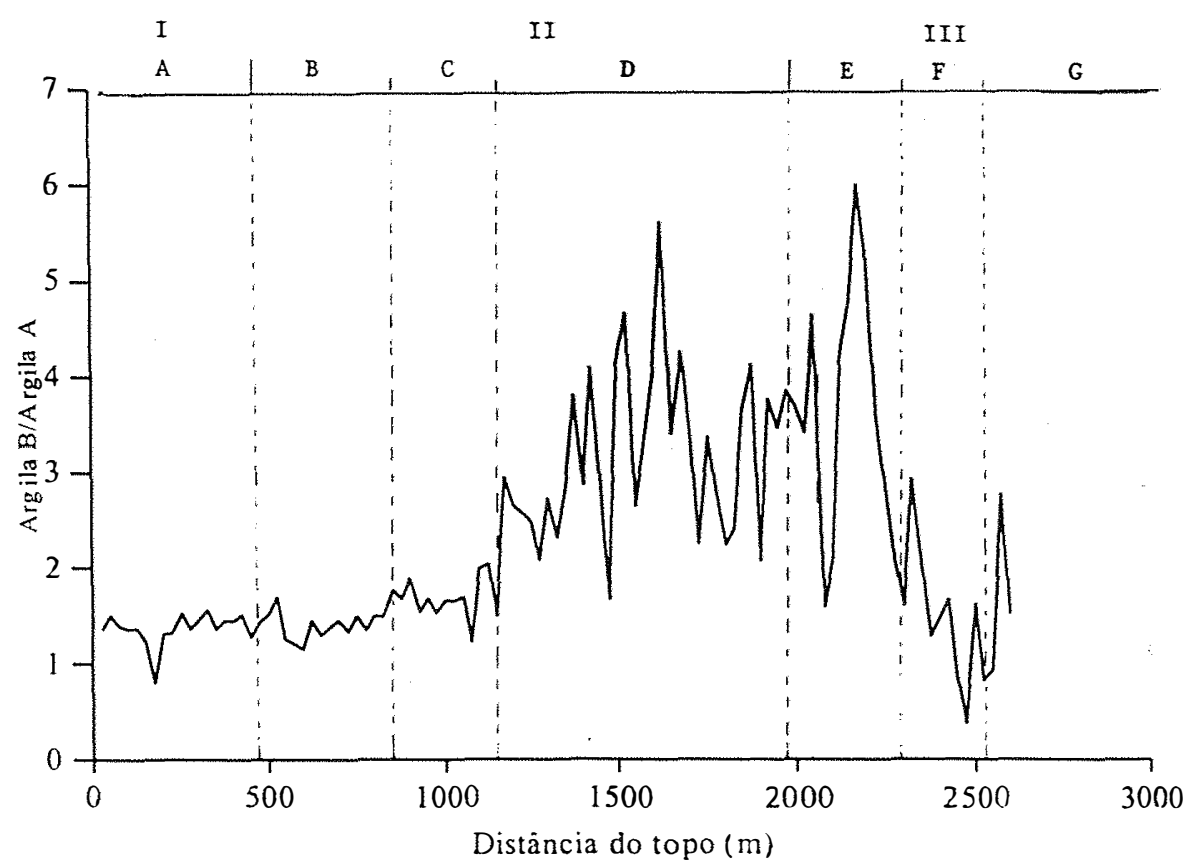

(b)

FIGURA 25. Comportamento de atributos do solo, em duas profundidades, ao longo da transeção de acordo com superficies geomórficas (números romanos) e seus segmentos decrescente a) Comportamento da soma de bases na transeção; b) Comportamento da relação argila do horizonte B/argila do horizonte A na transeção. 
resquícios de um solo com argila de atividade mais elevada, o que pode ser explicado por ser um antigo sopé, segmento um pouco mais preservado, ou formado diretamente sobre o arenito calcáreo.

O comportamento da matéria orgânica, acumulando-se nas posições da escarpa e sopé de deposição (FIGURA 24a), concorda com uma das hipóteses mais testadas nos trabalhos sobre a influência do relevo (WALKER et al., 1968 e MALO et al., 1974). Isto deve estar relacionado ao acumulo de bases (FIGURA 25a) e drenagem mais restrita numa fase do ano. VIDAL-TORRADO \& LEPSCH (1993) encontraram correlação positiva do acúmulo de matéria orgânica com declividades menores nas posições de sopé da encosta. Apesar do comportamento da matéria orgânica no horizonte A ter sido homogêneo até o segmento $\mathrm{F}$ da transeção, o acúmulo relativo pode ser considerado crescente, quando observa-se a diminuição do teor da argila na transeção (FIGURA 25b).

A maior variabilidade nos sopés (segmentos $\mathrm{G}$ e $\mathrm{H}$ ) para os parâmetros avaliados, é até certo ponto previsível tanto por ser ambiente erosional e deposicional como por conter os solos mais jovens. Vários materiais estão sendo aí depositados desuniformemente, causando grande variação nas características do solo (HALL, 1983).

Os parâmetros fisicos avaliados informam sobre o acréscimo de partículas finas ao longo da transeção. As relações silte/argila e areia fina/areia grossa (FIGURAS 26a e 26b), possuem a mesma tendência para os horizontes analisados, apresentando um aumento de partículas mais finas no sentido do declive da encosta, principalmente à partir de 1.975 metros. Este ponto é onde ocorre a transição das porções mais planas para as mais declivosas da paisagem.

A razão silte/argila informa sobre o grau de intemperização dos solos em relação à distância do topo. Solos com grande amplitude no grau de evolução podem ser observados. Os de menor valor de razão silte/argila, e por isso possivelmente com maior grau de evolução (latossólicos), situam-se mais próximos do topo, nos primeiros 500 metros da transeção (FIGURA 26a), com valores da relação inferiores a 0,7. Esta relação apresentase mais elevada no segmento $\mathrm{D}$ (pretérito sopé de deposição), principalmente no horizonte $\mathrm{A}$, que nesta posição apresenta-se mais espesso, sintoma de um ambiente aí mais preservado e possivelmente de maior eluviação e/ou maior degradação de argilas. Na Figura 26a observa-se 


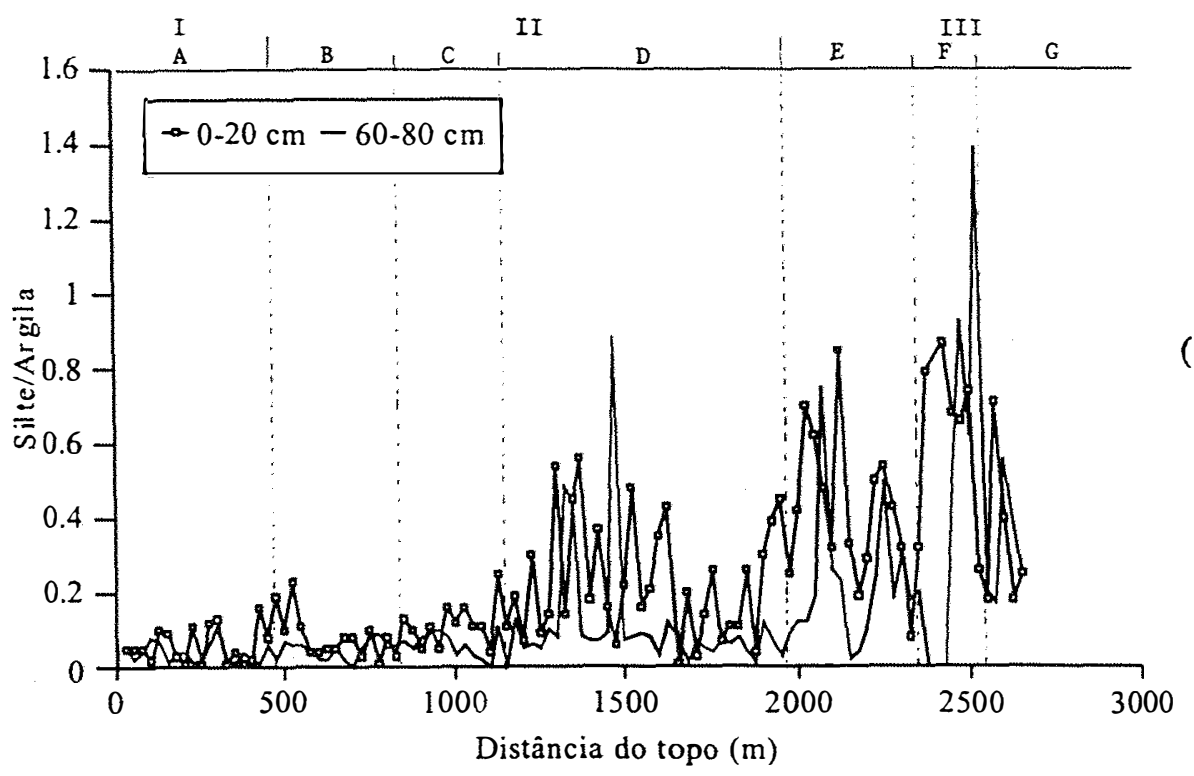

(a)

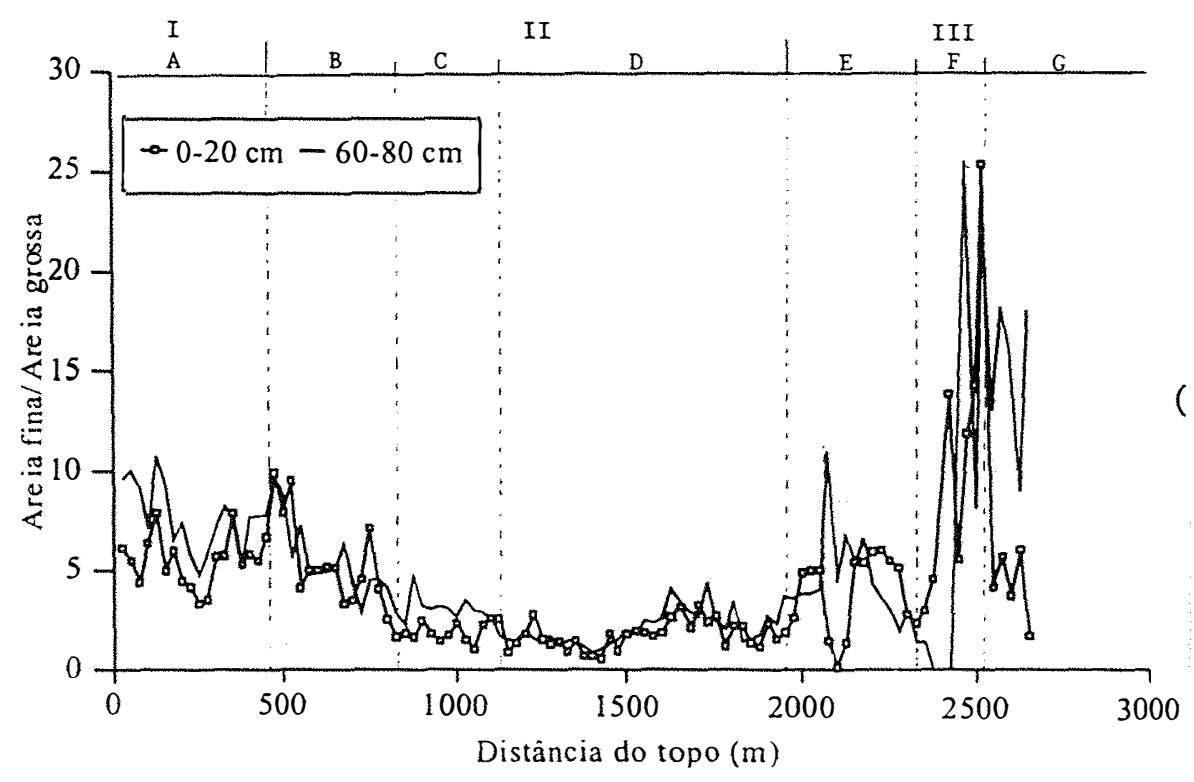

(b)

FIGURA 26. Comportamento de atributos do solo, em duas profundidades, ao longo da transeção de acordo com superficies geomórficas (números romanos) e seus segmentos decrescente a) Comportamento da razão silte/argila na transeção; b) Comportamento da razão areia fina/areia grossa na transeção. 
ainda que a argila do horizonte $\mathrm{A}$ tende a diminuir à medida que aumenta a distância do topo, consequência da "lessivage" e fluxo lateral cada vez mais intensa neste sentido.

A relação argila do horizonte $B /$ argila do horizonte A (FIGURA 25b) é mais homogênea até $850 \mathrm{~m}$ da transeção, seguindo-se de um aumento da relação ao longo da vertente. A tendência dessa relação reforça a idéia de mobilidade potencial da fração argila do horizonte A para o horizonte B na maior parte dos solos da transeção, caracterizando a presença de solos podzólicos. $O$ aumento da relação no segmento $D$, é explicado pela ocorrência dos podzólicos na porção correspondente aos horizontes $A+E$ espessos.

O comportamento das relações silte/argila e areia fina/areia grossa (FIGURAS 26a e 26b) pode estar confirmando o modelo deposicional da formação Marília, onde na base, o paleoclima úmido e quente de períodos mais secos influenciou a deposição de arenitos finos, e no topo arenitos conglomeráticos e calcário impuro, depositados em um paleoclima mais seco e quente (SUGUIO, 1980).

Estes resultados, portanto, ressaltam a eficiência da transeção como método de amostragem, em áreas onde se pretende entender a ocorrência dos solos e a variabilidade de propriedades básicas. Alertando sobre a importância da representatividade das amostras de material de solo, condição essencial para interpretações e extrapolações, CLINE (1944) e PECK \& WELSTED (1967) salientam que o limite de exatidão geralmente depende mais da qualidade da amostra do que da análise.

Na observação da amplitude desses parâmetros, já pode ser percebido que os solos nesta área ocorrem compartimentados em situação de dependência do comportamento da vertente e de características deposicionais do paleoambiente.

Portanto, a avaliação da variabilidade das propriedades na transeção revela o seu comportamento em relação aos diferentes segmentos da vertente, ajudando no estabelecimento das classes de solos, e entendimento das suas relações, e predição de sua ocorrência na paisagem. 


\subsubsection{Avaliação da micromorfologia dos solos}

A descrição da micromorfologia sumária dos solos encontra-se no Apêndice

4.

A investigação das características micromorfológicas dos latossolos (perfis 1 e 2) da superficie I e podzólico da superficie II, mostra que o quartzo foi o mineral predominante com a presença de outros como turmalina e feldspatos, estes últimos presentes somente nos podzólicos (FIGURAS 27a e 27b).

No perfil do latossolo a grande maioria dos grãos apresenta-se arredondadas a subarredondadas e uma distribuição média de $40 \%$ em grãos, $30 \%$ de plasma e $30 \%$ de poros, exceto no horizonte Ap, que apresenta uma distribuição de $60 \%$ de grãos, $15 \%$ de plasma e $25 \%$ de poros. A trama gefúrica possui presença de microagregados e domínios porfirico aparentemente formados por "empacotamento" de microagregados, alguns microagregados ovais de tamanho em torno de $1 \mathrm{~mm}$, com esqueleto triado no seu interior (origem biológica); outros microagregados são do tamanho de areia muito fina e não possuem esqueleto no seu interior. A estrutura do plasma para os perfis desses latossolos é predominantemente isótica de cor bruno-avermelhada (2,5YR), e as feições apresentam nódulo de trama porfirico com tamanhos aproximadamente de $2 \mathrm{~mm}$, contorno oval e presença de nódulos ferruginosos, tamanho areia média e fina comum. Estes resultados estão de acordo com vários estudos sobre a formação dos microagregados sob influência de processos geoquímicos definidos (PEDRO et al., 1976; SANTOS et al., 1989), além de processos biológicos (ESCHENBRENNER, 1986; MIKLÓS, 1995) e presença de plasma isótico dominando o horizonte B de latossolos (LEPSCH et al., 1977; SANTOS et al., 1989; VIDAL-TORRADO, 1994).

No LVp (perfil 2), um solo profundo, com baixo gradiente textural, o plasma é isótico em todo o perfil e está associado com certo desenvolvimento de estrutura em blocos (que se desfazem em grânulos) (Apêndice 4). Isto, associado à ausência de cutãs, confirma a presença do latossolo em área linútrofe aos podzólicos, confirmando resultados da aplicação do teste "split moving windows" para vários parâmetros desses solos. A trama, grãos, plasma 

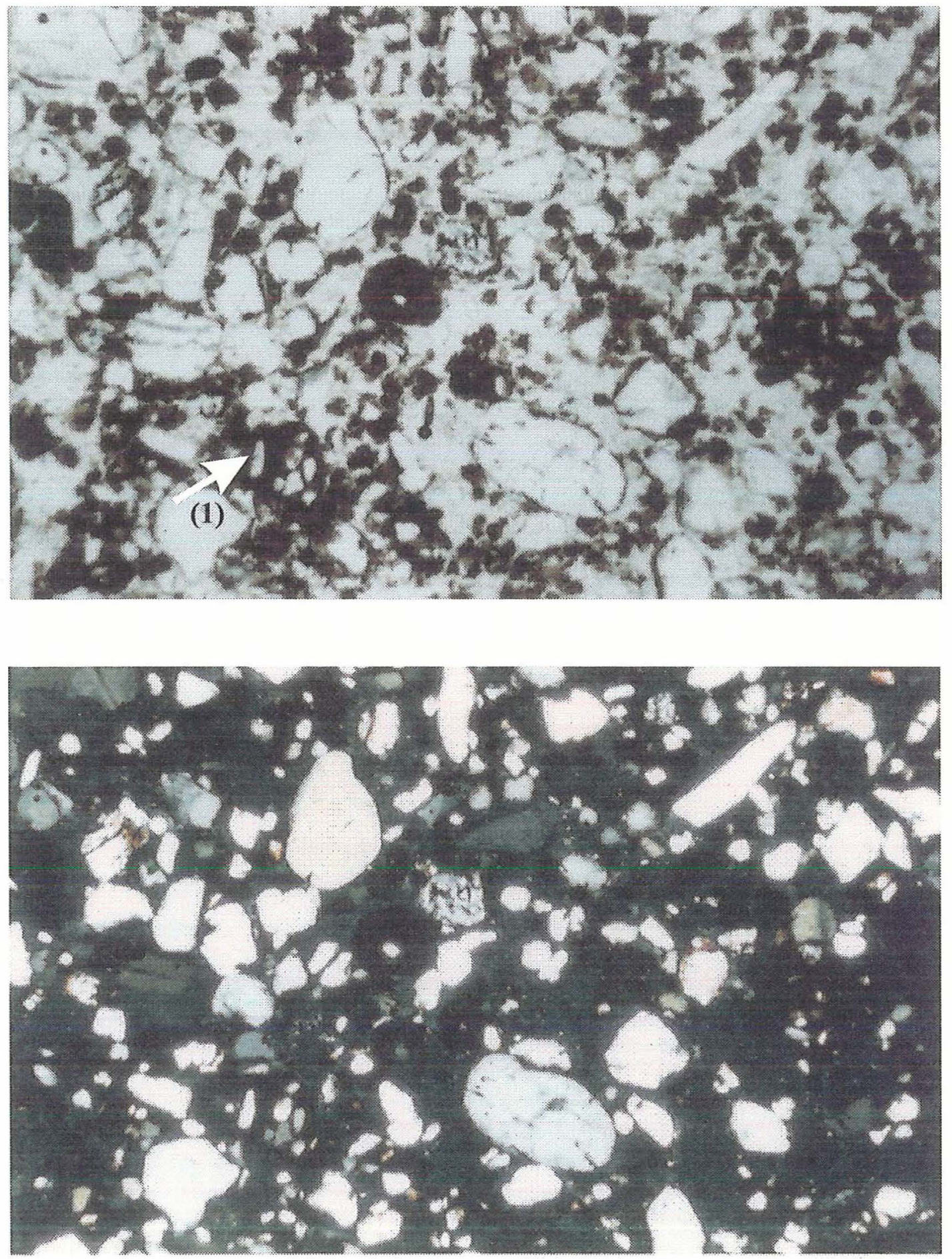

Figura 27. Perfil 1 , horizonte $\mathrm{Bw}_{2}(80-128 \mathrm{~cm})$, microagregrado biológico (1), trama gefúrica com plasma isótico. Fotomicrografia sob luz polarizada em um plano (a) e com nicóis cruzados (b). 
e feições são muito similares àquela apresentada no LV (perfil 1). A adjetivação podzólico é devida ao gradiente textural verificada nas tradagens de campo, realizados por a delimitação desta unidade de mapeamento.

$\mathrm{Na}$ meia encosta, o perfil do podzólico vermelho-amarelo (perfil 3), apesar de ser bastante típico da classe, principalmente por apresentar caráter abrupto e cerosidade, apresenta no horizonte $B$, grãos, trama e plasma com alguma tendência latossólica (Apêndice 4, FIGURAS 28a e 28b).

No horizonte Ap destes solos, os grãos de quartzo apresentam-se moderadamente selecionados (areia ligeiramente mais grosseira), com baixo arredondamento, e há presença de turmalina. A trama é quitônica, localmente gefúrica no horizonte $\mathrm{A}$, e gefúrica localmente porfirica no horizonte Bt2 (FIGURAS 28a e 28b), e o plasma é isótico. A distribuição aproximada é de $65 \%$ de grãos, $5 \%$ de plasma e $30 \%$ de poros, passando a $40 \%$ de grãos, $30 \%$ de plasma e $30 \%$ de poros no horizonte $\mathrm{Bt}_{2}$. A presença de ferriargilã pode ser visualizada com observação em microscópio com nicóis cruzados (FIGURA 28b).

O perfil do podzólico vermelho-amarelo localizado no sopé da superficie II (Apêndice 2, perfil 4), apresenta no horizonte $\mathrm{Bt}_{1}$ grãos moderadamente a pouco selecionados (areia média e areia fina com alguns grãos de areia grossa, arredondada a sub-arredondada com esfericidade variada), plasma isótico localmente vossépico, passando a massépico (brunoavermelhado), com segregação de ferro (FIGURAS 29a e 29b, APÊNDICE 4). Neste horizonte pode-se visualizar a presença de ferriargilãs de iluviação revestindo paredes de canais e poros, sendo sintomas do hidromorfismo temporário mais acentuado, condicionando iluviação de argila mais intensa (FIGURAS 30a e 30b). Isto pode estar contribuindo para a presença dos horizontes $\mathrm{A}+\mathrm{E}$ mais espessos dos podzólicos destes segmento da paisagem. CASTRO (1988) menciona que esse hidromor-fismo temporário promove a degradação do topo do horizonte Bt pela ocorrência de depleção química seguida por ação mecânica.

VIDAL-TORRADO (1994) explica que a argiluviação e a migração de ferro pode indicar a formação do gradiente textural entre $\mathrm{A}$ e $\mathrm{B}$, provavelmente às expensas do hori zonte B. A migração de argila inicial obstrui os poros do topo do horizonte B (onde as pápulas são fieqüentes), esse bloqueamento promove a migração de ferro devido ao hidromorfismo temporário, o que favorece ainda mais a argiluviação. Para ALMEIDA et al. (1995) 

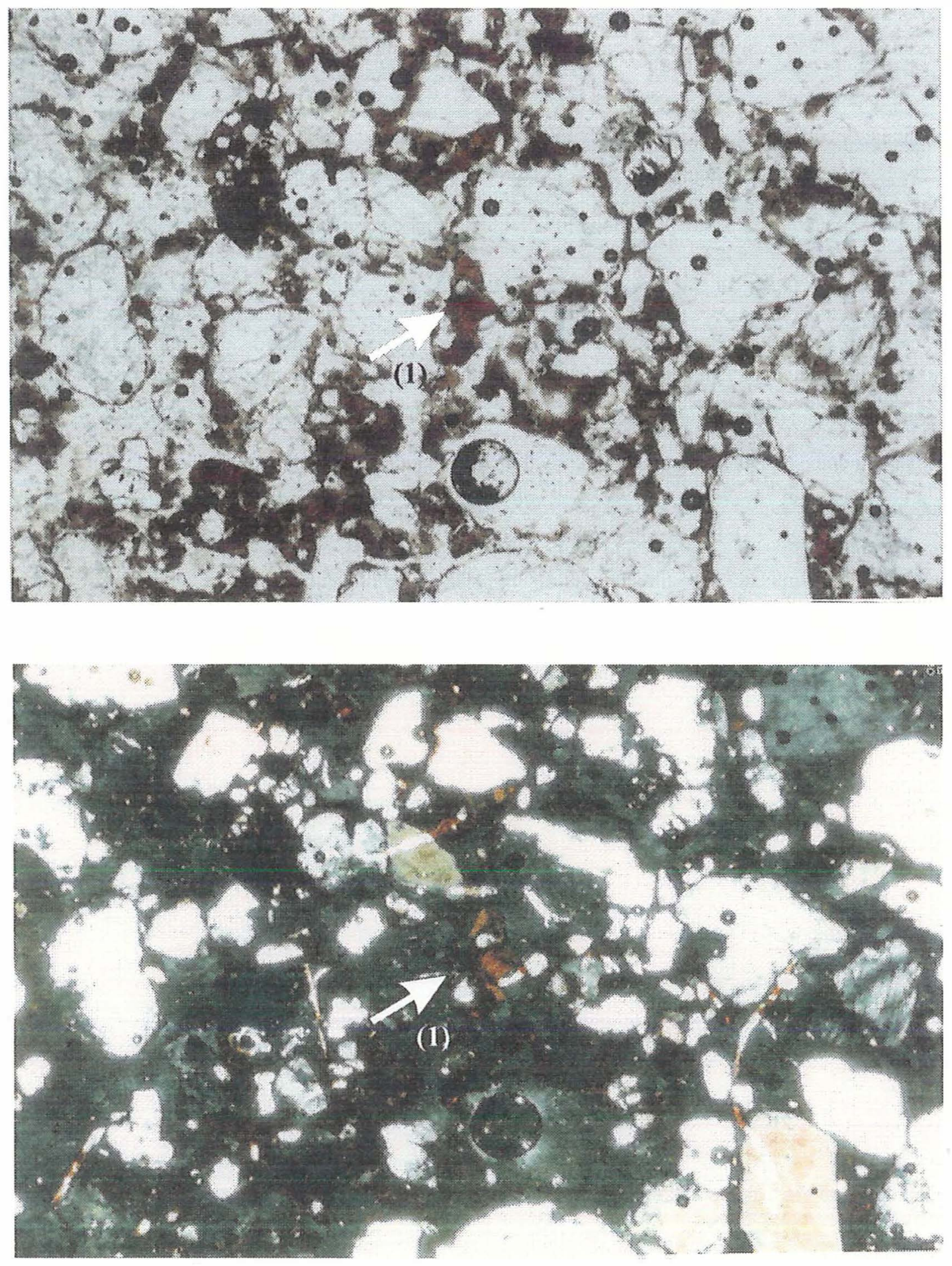

(b)

Figura 28. Perfil 3, horizonte $\mathrm{Bt}_{2}(100-165 \mathrm{~cm})$, trama quitônica localmente gefúrica, plasma isótico, presença de ferriargilã (1). Fotomicrografia sob luz polarizada em um plano (a) e com nicóis cruzados (b). 

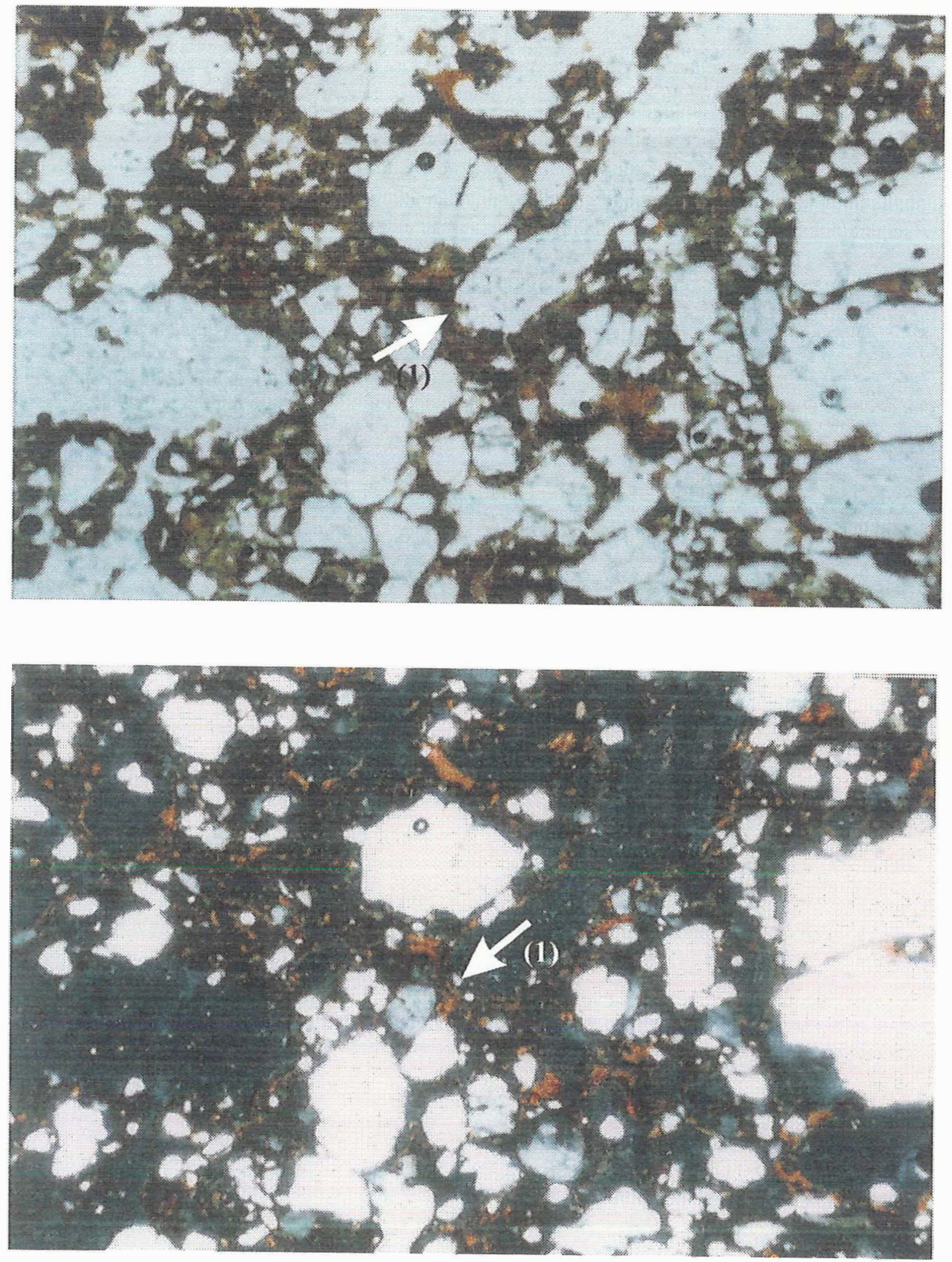

Figura 29. Perfil 4, horizonte $\mathrm{Bt}_{1}(61-104 \mathrm{~cm})$, plasma isótico localmente vossépico, cutãs de argiluviação (1). Fotomicrografia sob luz polarizada em um plano (a) e com nicóis cruzados (b). 


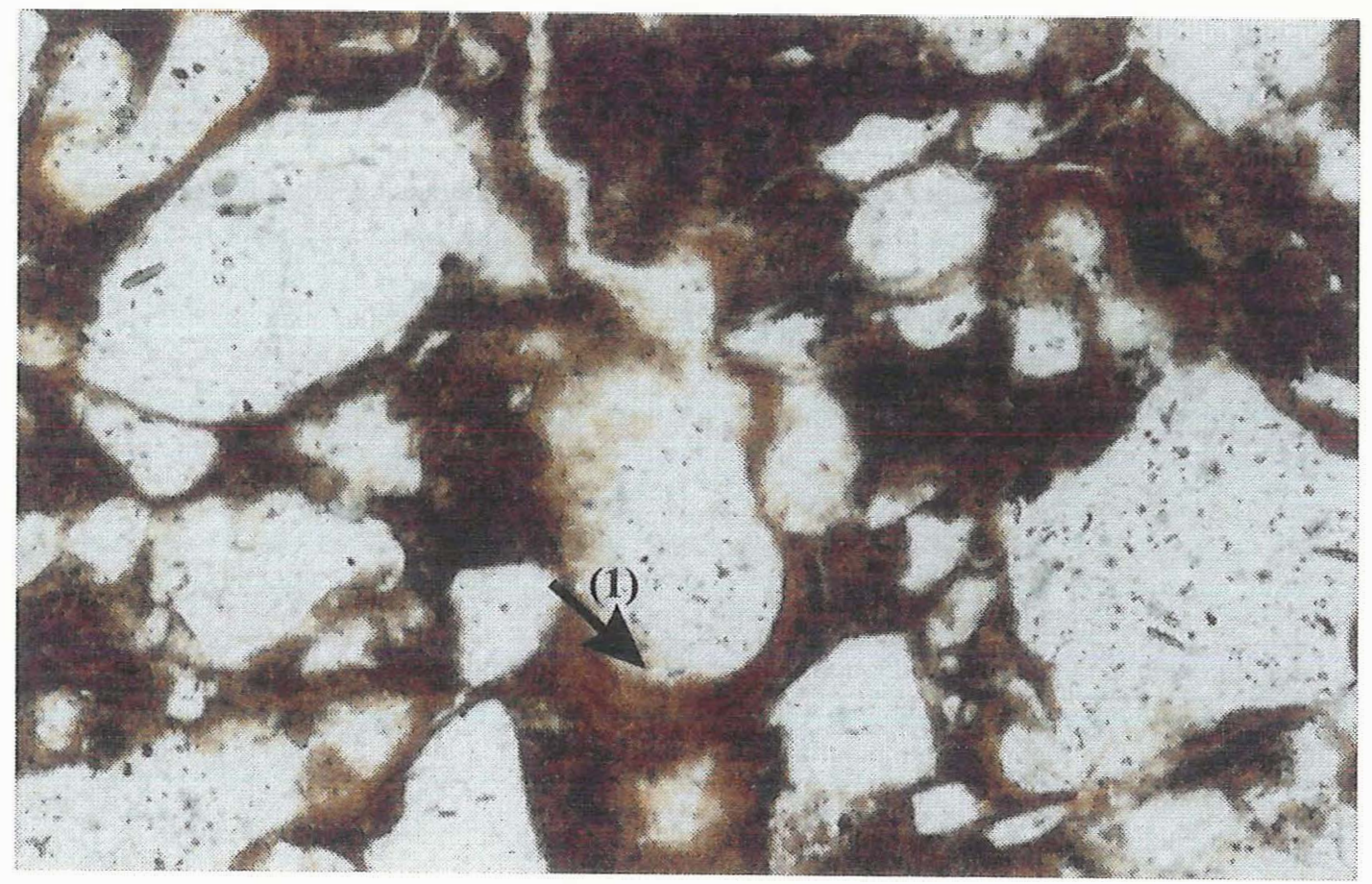

(a)

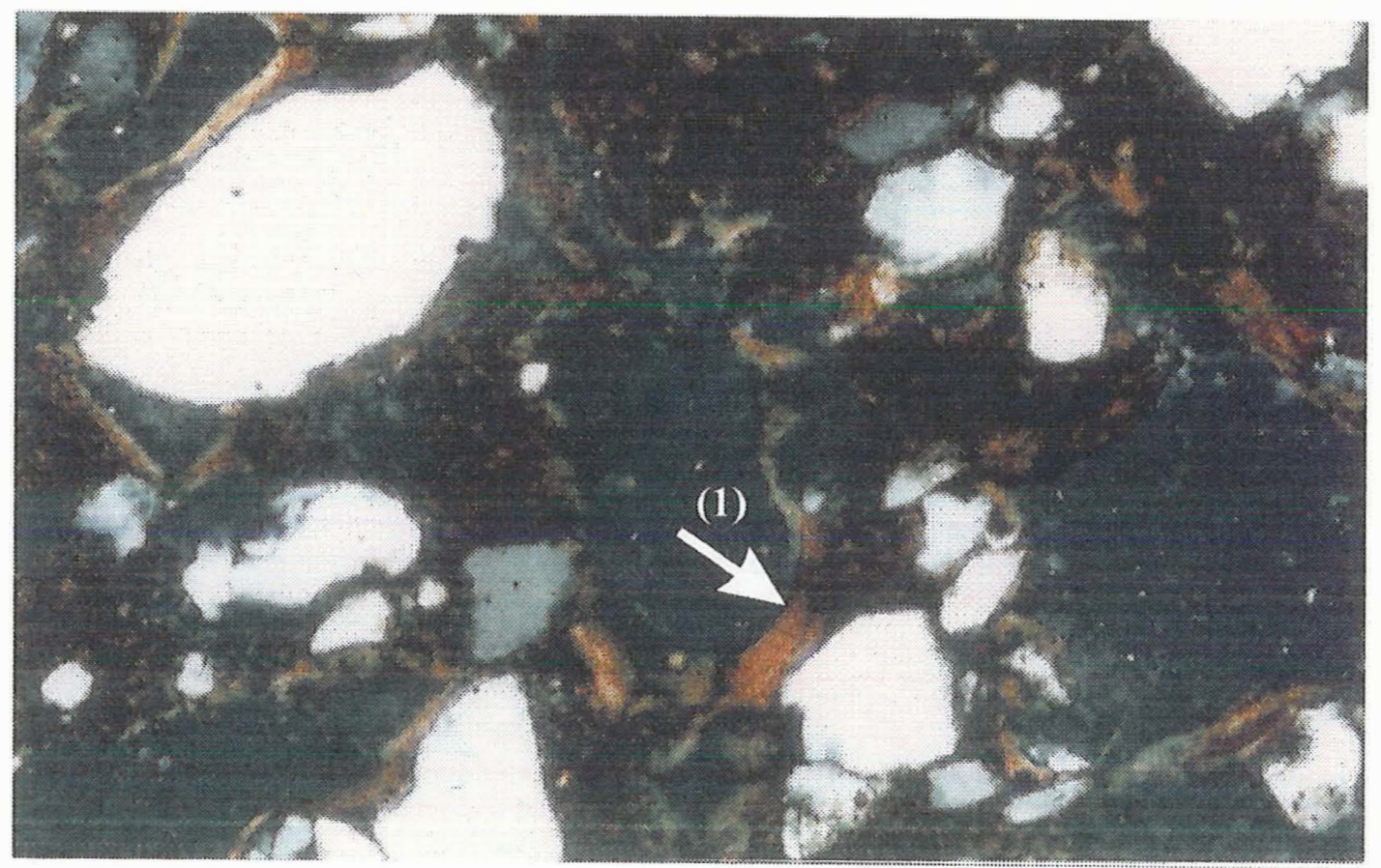

(b)

Figura 30. Perfil 4, horizonte $\mathrm{Bt}_{1}(61-104 \mathrm{~cm})$, plasma isótico localmente vossépico, cutãs de argiluviação (1). Fotomicrografia sob luz polarizada com aplicação de $150 x$ (a) e com nicóis cruzados (b). 
porém, associado ao processo de destruição de argilas no topo do horizonte $\mathrm{Bt}$, estão a argiluviação e remoção de argila por fluxo lateral, atuando de maneira conjunta para diferenciação textural do solo.

Constatou-se para estes podzólicos da superficie II uma desproporção entre a cerosidade observada no campo e a quantidade de cutãs de iluviação observada nas lâminas delgada (relativamente em menor quantidade). Vários autores discutem essa questão alegando que processo de expansão e contração podem provocar a destruição de cutãs (NETTLETON et al., 1969; ISBELL, 1980); ou que os estudos ainda incipientes não propiciaram conhecer a natureza exata das superficies brilhosas, bem como a origem da forma dos pedes (SOMBROEK, 1990).

O segmento ombro da escarpa (superficie III), área de ocorrência dos podzó licos erodidos, é marcado por uma mudança da morfoscopia e mineralogia da areia. O horizonte $\mathrm{E}$ do solo apresenta-se com $75 \%$ de grãos, $20 \%$ de plasma e $5 \%$ de poros. Os grãos apresentam-se moderadamente selecionados, sub-arredondados e de esfericidade variável (desde esféricos até angulosos). Ele possui além de quartzo e feldspatos com grau de alteração variada (íntegros a cariados), turmalina e zircão (FIGURAS 31 a e 31b). Este horizonte apresenta ainda faixas locais de argiluviação, obstruindo porosidade e interligando grãos de quartzo. No interior das faixas de argiluviação ocorre coalescência de cavidade com contorno mamelonar revestido por ferrãs (FIGURA 31 a e 31 b). Observa-se no horizonte B deste solo a presença de mica, que juntamente com o plasma de estrutura massépica com pápulas comuns, e de maior birrefringência (FIGURAS 32a 32b), são favorecidos pela ocorrência de argilas com atividade mais elevada (Apêndice 4), sintoma de solos com menor grau de intemperismo. Isto está de acordo com a superficie de ocorrência (holocênica) e, portanto, mais instável com declives mais acentuados, a indicar mudanças no fluxo de água subsuperficial.

Neste horizonte Bt foi registrada a máxima expressão da segregação de ferro da vertente estudada, visualizada na forma de ferrãs em torno de cavidades em posição cutânica a subcutânica. Isto indica o maior período de concentração de umidade durante o ano. Os ferriargilãs estão distribuídos aleatoriamente com segregação de ferro dificultando sua identificação. No campo foram registradas, através da morfologia, a presença de cerosidade forte, comum no horizonte $\mathrm{B}$, e a presença de lamela de $0,5 \mathrm{~cm}$ de espessura no horizonte $\mathrm{E}$ 

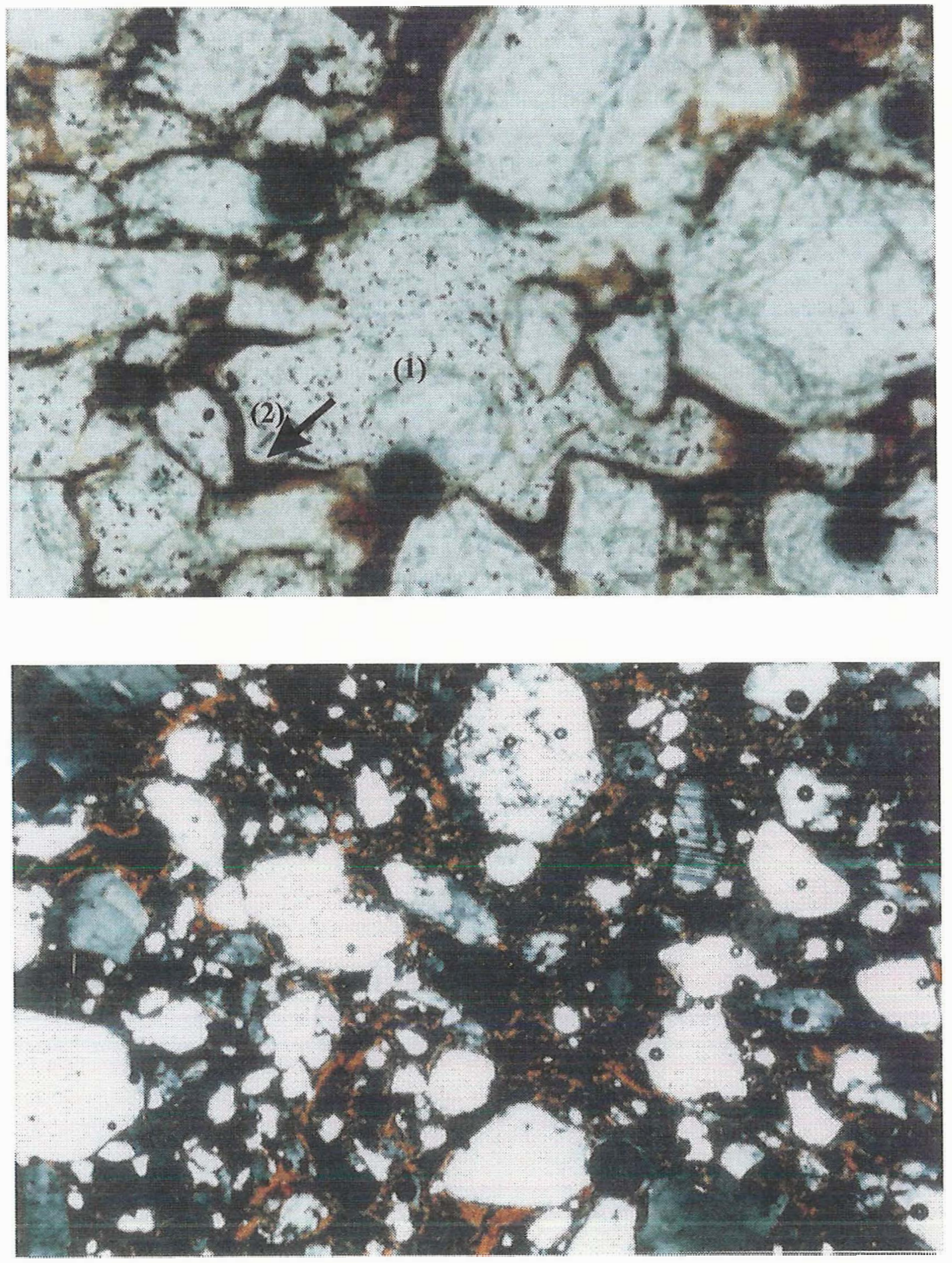

(b)

Figura 31. Perfil 5, horizonte E $(28-65 \mathrm{~cm})$, plasma isótico, faixa de argiluviação obstruindo porosidades; coalescência de cavidades com contorno mamelonar (1), revestido por ferrãs (2). Fotomicrografia de luz polarizada (a) e com nicóis cruzados (b). 

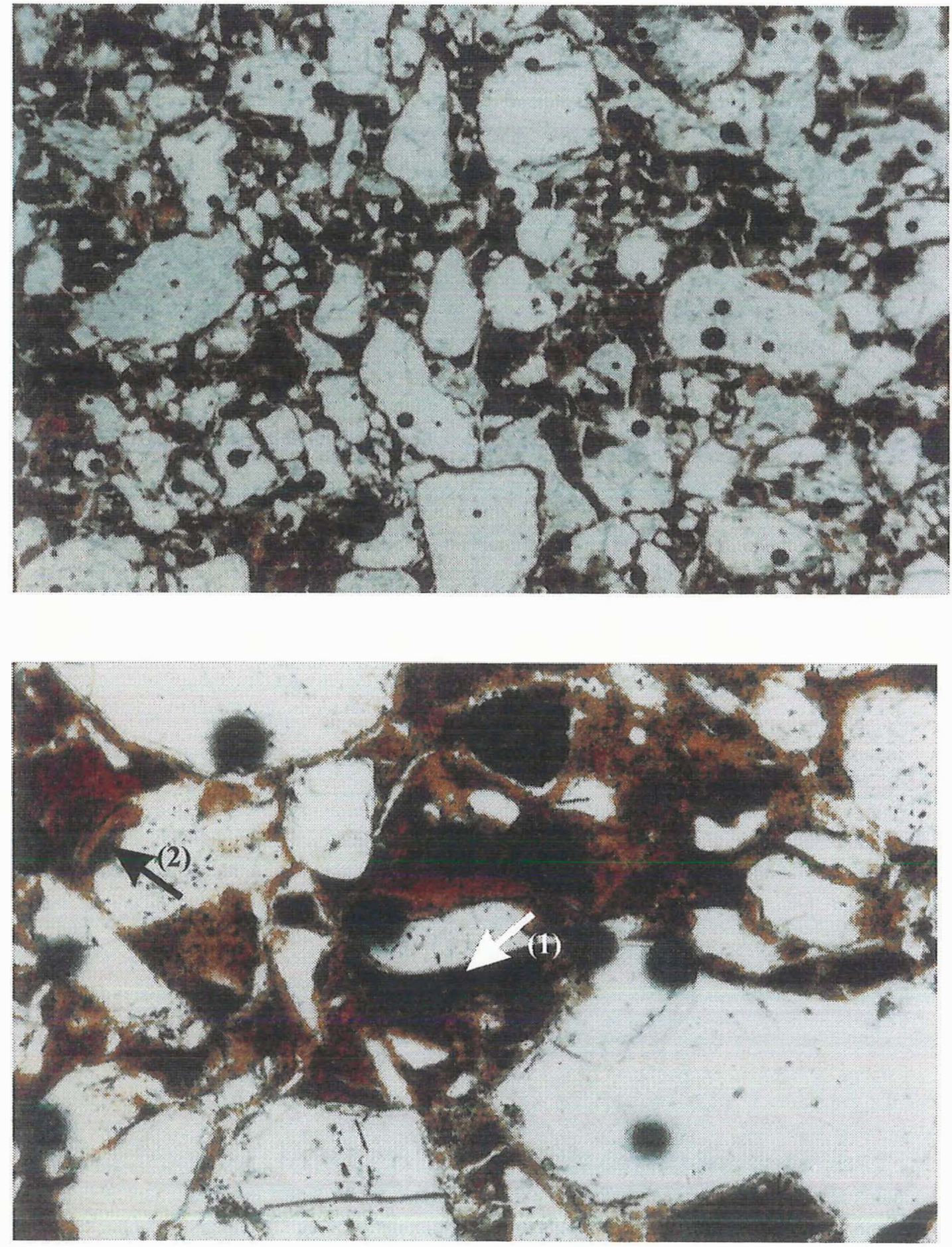

(b)

Figura 32. Perfil 5, horizonte $\mathrm{Bt}_{1}(61-100 \mathrm{~cm})$, plasma massépico, ferrãs (1) em torno de cavidades e ferriargilans de argiluviação (2). Fotomicrografia com luz polarizada em um plano (a) e (b). 
(Apêndice 2). Estas características reforçam a idéia da gênese do gradiente textural à partir de frentes de argiluviação contínua, que iniciaram na transição do horizonte $\mathrm{B}$ para $\circ \mathrm{E}$ ou $\mathrm{A}$, com posterior degradação de argilas nas lamelas, causado pela redução drástica da porosidade nessas zonas, condicionando encharcamento temporário nesses locais. A presença de poros com ferrãs e a coalescência cavitária reforçam esta hipótese. BERG (1984) e BOND (1986) atribuem a presença de lamela no horizonte $\mathrm{E}$ dos podzólicos, à rápida migração de argilas causado por um desequilibrio fisico-químico da reação do solo devido a retirada da cobertura vegetal, que da início ao processo de argiluviação.

\subsubsection{Avaliação qualitativa e quantitativa da mineralogia da fração argila desferrificada}

Os resultados da avaliação qualitativa e quantitativa da fração argila desferrificada são apresentados no Quadro 5 e Apêndice 4.

Os difratogramas de raios $\mathrm{X}$ da argila tratada com DCB (APÊNDICE 5) evidenciam que os latossolos apresentam um domínio de caulinita $(\mathrm{Ct})$ e gibbsita $(\mathrm{Gb})$ nesta fração. Os reflexos da caulinita são bem expressos, para ambos horizontes, demonstrando alta estabilidade desses minerais.

Estes dados concordam com os estudos de LEPSCH (1977) quando alega que a caulinita por ser o mineral da fração argila mais resistente encontrado na área, suas quantidade relativas podem ser usadas para estimar o estágio de intemperismo dos solos. Isto pode ser reforçado pela melhor expressão e simetria dos picos da caulinita nos solos da superficie I e II, com diminuição significativa da expressão desses picos nos solos da superficie III (APÊNDICE 5). O solo PV-4 apresenta baixos teores relativos de caulinita (QUADRO 5). devida ao gradiente textural apresentado, e pela grande expressão deste gradiente verificada nas tradagens de campo, realizados para delimitação desta unidade de mapeamento.

DECHEN et al. (1994) trabalhando com solos desenvolvidos do arenito Bauru associa a boa expressão dos picos da caulinita à alta estabilidade desses minerais, alegando sua origem na rocha. Nos solos em estudo, percebe-se uma boa simetria nos picos a 
7,2 \& para estes solos, indicando que a caulinita está totalmente cristalizada (PÖTTER \& KÄMPF, 1981).

A gibbsita, em geral, ocorre em menores quantidades na argila destes solos (QUADRO 5), e sua expressão nos difratogramas também é menor (APÊNDICE 5). Este mineral foi detectado pela difração de raios $\mathrm{x}$ pelos picos a $3,4 \AA$ e $4,8 \AA$ e pelo termograma através do pico endotérmico entre 300 e $350^{\circ} \mathrm{C}$ (APÊNDICE 5). A pequena quantidade de gibbsita, encontrada principalmente nas superficies I e II, concorda com os resultados de LEPSCH et al. (1977a) estudando solos de mesma origem, que a justifica, mesmo estando esses solos presentes em superficies antigas, pela alta atividade do ácido silícico oriundo dos altos teores de areia fina, favorecendo assim a estabilidade da caulinita e maior inibição da formação da gibbsita. Este modelo foi confirmado por MARQUES JÚNIOR (1988) para latossolos com teor de ferro diferenciais na origem. Aqueles com menor teor de ferro apresentaram menores quantidades de gibbsita, o que foi justificado pela maior concentração de sílica na solução como inibidora da formação de gibbsita. Algumas propriedades químicas dos latossolos, como presença de $\mathrm{Al}^{3+}$ e $\Delta \mathrm{pH}$ negativo (FIGURA 17) tendem também a confirmar este modelo.

No cambissolo situado no sopé de transporte da superficie III, o teor de gibbsita é relativamente elevado, mediante o que seria esperado para este solo pedogeneticamente jovem (QUADRO 5), inclusive com presença de montmorilonita na fração argila (APÊNDICE 5). As condições descritas por DAYRLYMPLE et al. (1968) para este segmento da vertente, como transporte intenso de materiais na superficie, removendo rapidamente materiais como sílica e bases, pode estar condicionando um ambiente propício à transformação direta de feldspatos em gibbsita. Este modelo encontra respaldo nos trabalhos de McCRAKEN et al. (1971) e ROTTA et al. (1976), que também encontraram apreciáveis teores de gibbsita em solos jovens em posições da paisagem similares aos do presente estudo.

Nos podzólicos da superficie II observa-se um aumento relativo da relação $\mathrm{Ct} / \mathrm{Ct}+\mathrm{Gb}$ (QUADRO 5), e a mica apresenta-se através dos picos $10 \AA$, $5 \AA$ e $3,3 \AA$ (APÊNDICE 5). 
A relação $\mathrm{Ct} / \mathrm{Ct}+\mathrm{Gb}(\mathrm{QUADRO} 5)$ possui seu menor valor no latossolo da superficie I, concordando com suas características de solo mais intemperizado. Os valores desta relação apresentam-se muito próximos para os podzólicos da superficie II, concordando com outras características que tornam estes solos semelhantes.

QUADRO 5. Teores de caulinita e gibbsita na fração argila desferrificada e taxa de caulinita/(caulinita+gibbsita).

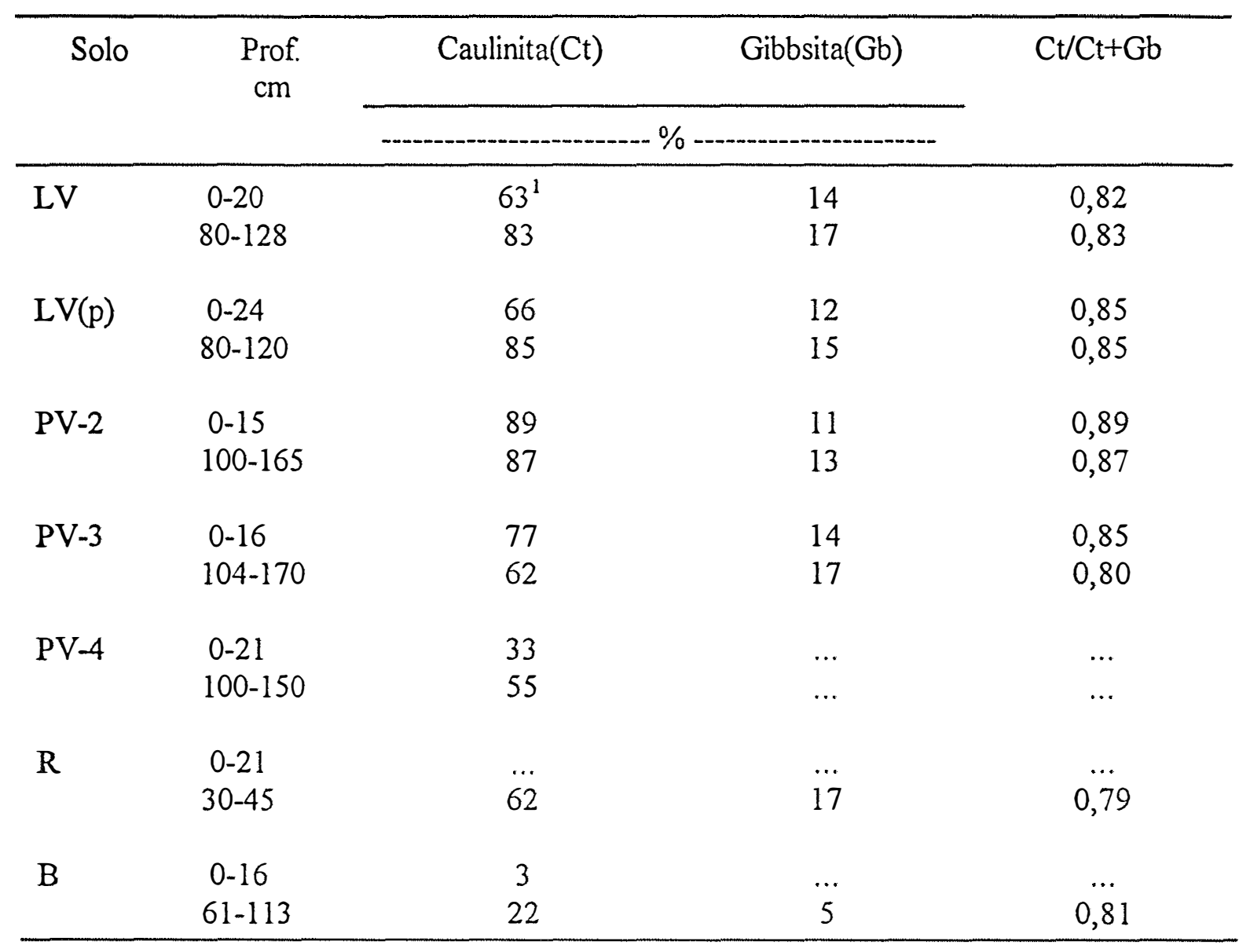

${ }^{1}$ Valores obtidos através de análise térmica diferencial (ATD).

... Não determinado.

No cambissolo e no brunizém está registrado a presença de esmectita (montmorilonita), no reflexo 17,6 $\AA$ na amostra saturada com magnésio-glicol, e 15,6 
quando saturada com magnésio, que sofre um colapso a 14 e $10 \AA$ quando saturada com potássio na temperatura ambiente. Este comportamento sugere que esta esmectita possui carga negativa bastante elevada, concordando com seus elevados valores de CTC da argila (QUADRO 6). LEPSCH (1977) menciona que a esmectita nestes solos tem origem na rocha, bem como produto do intemperismo da atapulgita.

No horizonte Bt2 do brunizém, o tratamento com magnésio-glicol (reflexo 16,3 $\AA$ ) revela uma menor capacidade expansiva da esmectita, já que para este mesmo tratamento no horizonte $\mathrm{Al}$ deste solo e horizontes $\mathrm{A}$ e B/A do cambissolo, o reflexo é de 17,6 $\AA$. Isto revela um bloqueio mais acentuado das entrecamadas, identificando a formação de esmectita com polímeros de hidróxi-Al entrecamadas (EHE); esta ocorrência pode explicar a menor CTC da argila neste solo, em relação ao cambissolo (QUADRO 6). Segundo KARATHANASIS \& HAJEK (1983), a precipitação de $\mathrm{Al}-\mathrm{OH}$ entrecamadas pode ser um mecanismo precursor de reorganização estrutural no processo de transformação da esmectita em caulinita.

\subsubsection{Formas de ferro extraido com ditionito e oxalato}

O resultado das formas de ferro extraído pelo ditionito-citratobicarbonato de sódio $\left(\mathrm{Fe}_{\mathrm{d}}\right)$ e pelo oxalato de amônio ácido $\left(\mathrm{Fe}_{\mathrm{o}}\right)$ dos horizontes $\mathrm{A}$ e $\mathrm{B}$ dos solos são apresentados no Quadro 6.

Os óxidos de ferro estão presentes nestes solos e podem ser avaliados através dos teores de ferro extraídos pelo ditionito-citrato-bicarbonato (DCB) e oxalato. Conforme MEHRA \& JACKSON (1960), o DCB extrai todos os óxidos de $\mathrm{Fe}^{3+}$ livres, enquanto que o oxalato de amônio ácido na ausência de luz (SHWERTMANN, 1964), extrai somente as formas pouca ordenadas, a exemplo da ferrihidrita.

Os valores de $\mathrm{Fe}_{d}$ do LV apresentam-se mais baixo do que para LVp, e os podzólicos apresentam teores crescentes ao longo da vertente, atingindo o valor máximo no solo PV-4 localizado no ombro que antecede a escarpa (FIGURAS 33a e 33b). O brunizém apresenta os menores teores desta forma de ferro e maior tendência 
de estabilização após a terceira extração. Este solo em contrapartida possui os maiores teores de ferro oxalato (QUADRO 6), seguido pelo PV-3 e PV-4.

$\mathrm{O}$ índice relativo da atividade do ferro, avaliado pela inclinação inicial (primeira e segunda extração) da curva de extração de ferro pelo ditionito-citratobicarbonato ( $\mathrm{Fe}_{\mathrm{d}}$ ) (FIGURA 33), indica que o PV-4 (superficie III) têm $\mathrm{Fe}_{\mathrm{d}}$ mais ativo, seguido pelos latossolos e podzólicos (superficies I e II). Esses padrões de curva mostram que há uma fração inicial, possivelmente com menor índice de cristalinidade (tamanho) ou menor substituição de Fe por AJ (GUALBERTO et al., 1987; MARQUES JÚNIOR, 1988), com tendência a uma horizontalização (principalmente nos podzólicos), que não se completa de todo; há ainda minerais sendo destruídos numa taxa muito lenta. Neste sentido há dois grupos de compostos de ferro com reatividade diferencial ao ditionito nos podzólicos e brunizém, e nos latossolos parece que os minerais de ferro são mais homogêneos. A tendência de homogeneização mais rápida no brunizém deve-se ao menor teor $\mathrm{deFe} \mathrm{d}_{\mathrm{d}}$ cujos minerais são destruídos numa taxa mais rápida.

Os valores de $\mathrm{Fe}_{d}$ mais baixos e da relação $\mathrm{Fe}_{\mathrm{d}} / \mathrm{Fe}_{d}$, (QUADRO 6), relativamente mais elevados verificados no horizonte $\mathrm{B}$ do brunizém, quando comparados aos demais solos, podem ser atribuídos ao maior grau de umidade desses solos, por estarem localizados no sopé de deposição. Assim a maior restrição à drenagem nestes solos inibe a formação de óxidos de ferro de maior cristalinidade (SCHWERTMANN \& TAYLOR, 1977 e FITZPATRICK \& SCHWERTMANN, 1982).

Os baixos valores da relação $\mathrm{Fe}_{0} / \mathrm{Fe}_{d}(<0,016)$ nos solos das superficies I e II, indicam a predominância de formas cristalinas destes óxidos (KÄMPF \& SCHWERTMANN, 1983); e também de que a presença de ferrihidrita é de pouca significância nestes solos (KÄMPF et al., 1988). A relação $\mathrm{Fe}_{\mathrm{d}} / \mathrm{Fe}_{\mathrm{t}}$ como indicadora do estádio de evolução dos solos, apresenta-se maior nos latossolos (QUADRO 6), confirmando serem estes os solos mais intemperizados da área.

O ferro extraído pelo DCB possui uma boa correlação com os teores de argila (LEPSCH, 1975). A relação argila/Fe $e_{d}$ (QUADRO 6) apresenta mais elevada nos 
QUADRO 6. Formas de Fe e CTC da argila dos solos estudados.

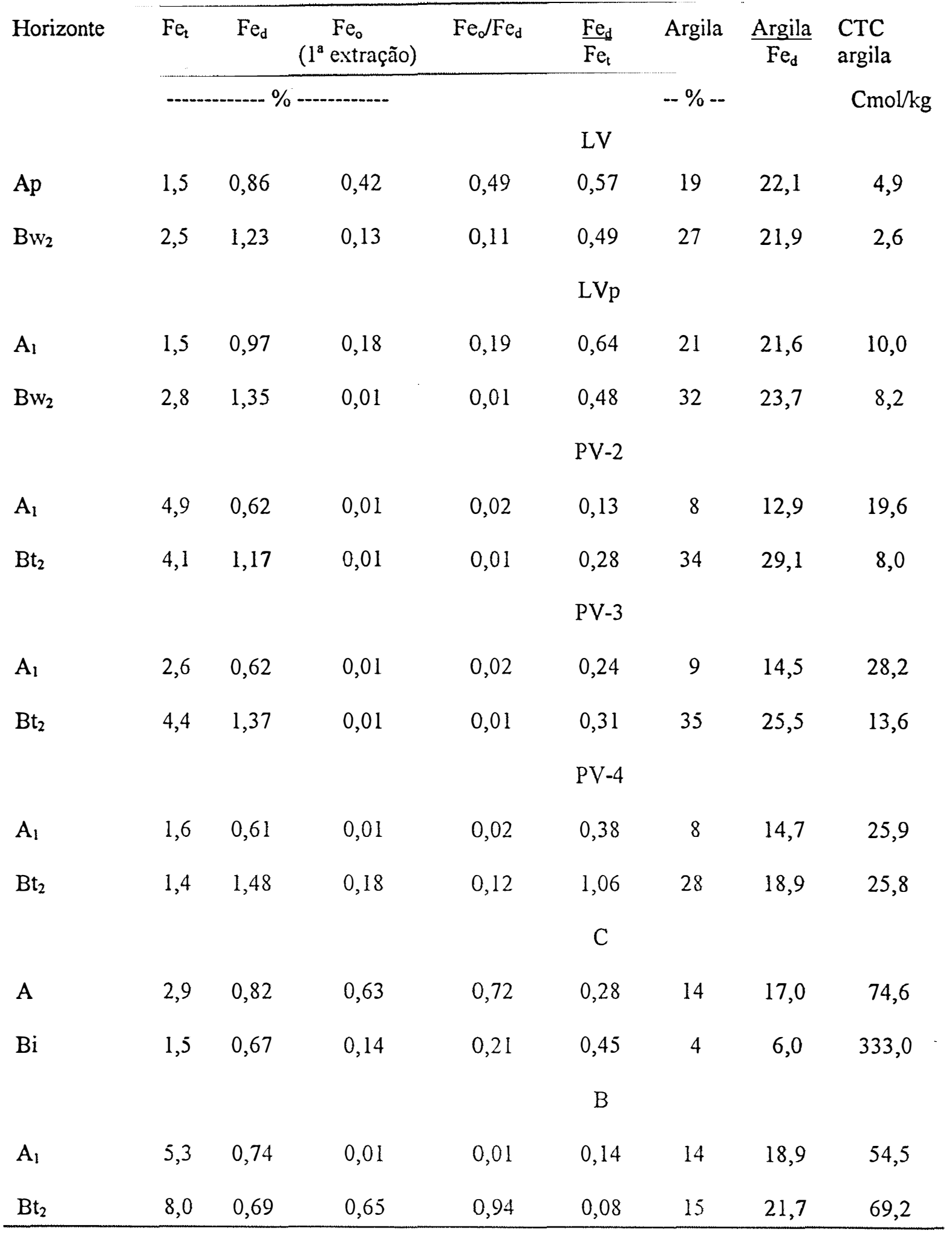



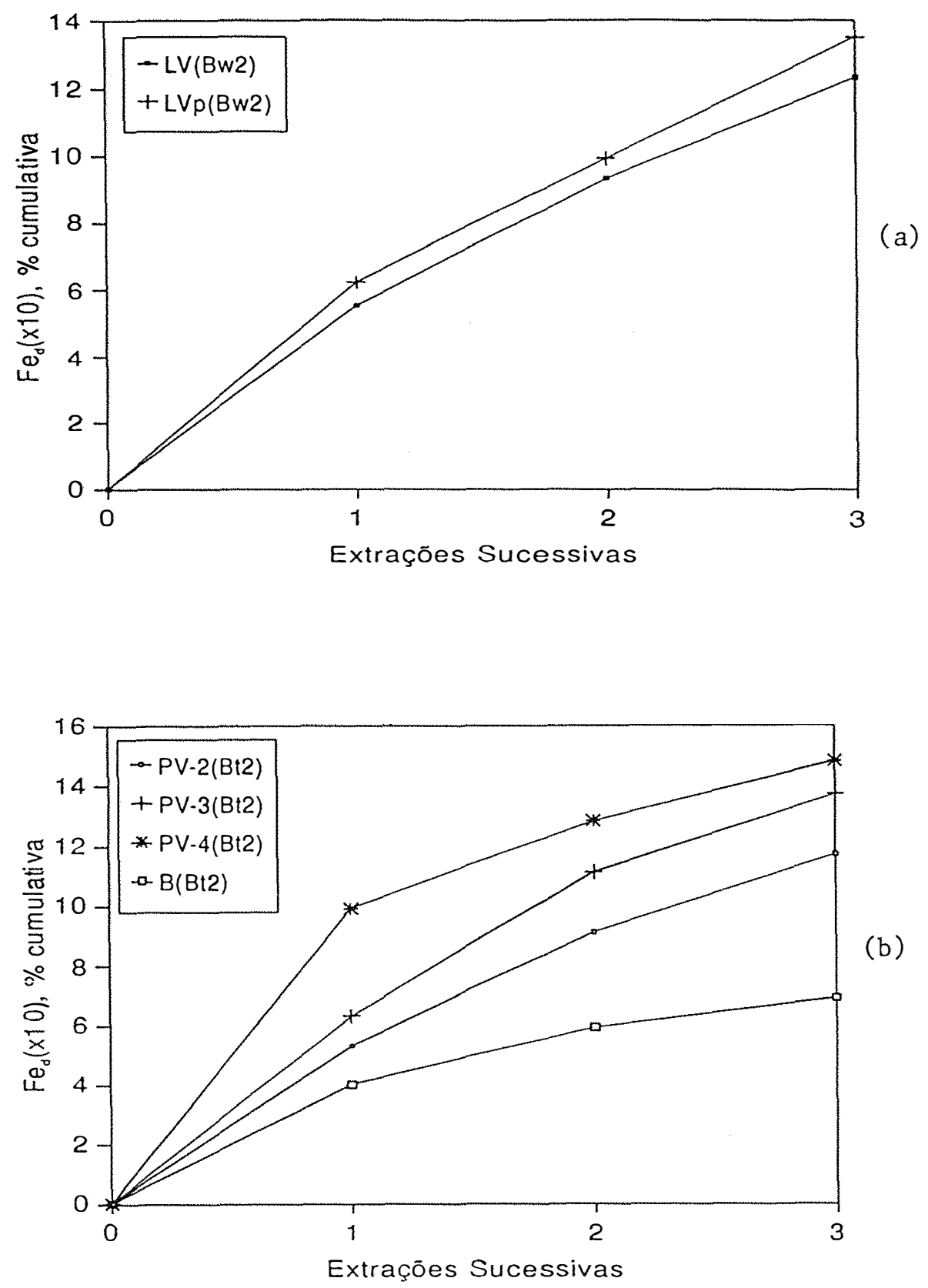

(b)

FIGURA 33. a) Teor de Fe extraído pelo ditionito-citrato-bicarbonato de sódio (DCB) da fração argila dos latossolos; b) Teor de Fe extraído pelo ditionito-citratobicarbonato de sódio (DCB) da fração argila dos podzólicos. 
horizontes B de todos os solos com horizonte Bt estudados, informando sobre a menor concentração de ferro nestes horizontes iluviais. Isto demonstra que o mecanismo de mobilização e perdas de ferro está intimamente associado aos mecanismos que regem a mobilização e perda de argila nos horizontes do solo.

Resultados similares foram encontrados por LEPSCH (1975), quando foi apresentado um modelo para explicar a formação do horizonte Bt em encosta mais declivosa, adjacente à latossolos. O movimento lateral de água nos horizontes superficiais contribui para a redução do ferro, devido o empobrecimento em oxigênio pela maior atividade biológica superficial. Os óxidos de ferro nos horizontes superficiais reduzidos podem ser removidos do perfil. A argila livre do ferro, seria então eluviada para formar o horizonte B textural.

\subsection{Avaliação estatística da granulometria das areias}

Nas Figuras 34 e 35, são apresentados a média, desvio-padrão, assimetria e curtose da distribuição granulométrica das areias nas camadas de 0-20 e 60$80 \mathrm{~cm}$ dos solos ao longo da transeção, com ênfase nas unidades de vertente.

Apesar destes dados terem sido obtidos a partir de cinco classes de tamanhos de partículas, sendo que o método de FOLK \& WARD (1957) foi idealizado com um número maior de classes, existe uma coerência nos resultados que auxiliam o entendimento da variabilidade dos solos, aplicados ao modelo de RUHE (1956) e de DARLYMPLE et al. (1968), para área em estudo.

Nos segmentos mapeados como topo (A) da superficie I, e ombro superior (B) na superficie II, as areias estão enquadradas predominantemente como moderadamente selecionadas e platicúrticas, porém com tendência a possuir um maior grau de seleção em relação às do segmento seguinte (FIGURA 34b). A assimetria apresenta valores entre $+0,3$ a $-0,5$, predominando a negativa (grosseiros) (FIGURA 34b), e para a média, a maior parte dos pontos está entre 2,2 e 2,8 phi (FIGURA 35a) nestes segmentos da vertente. 

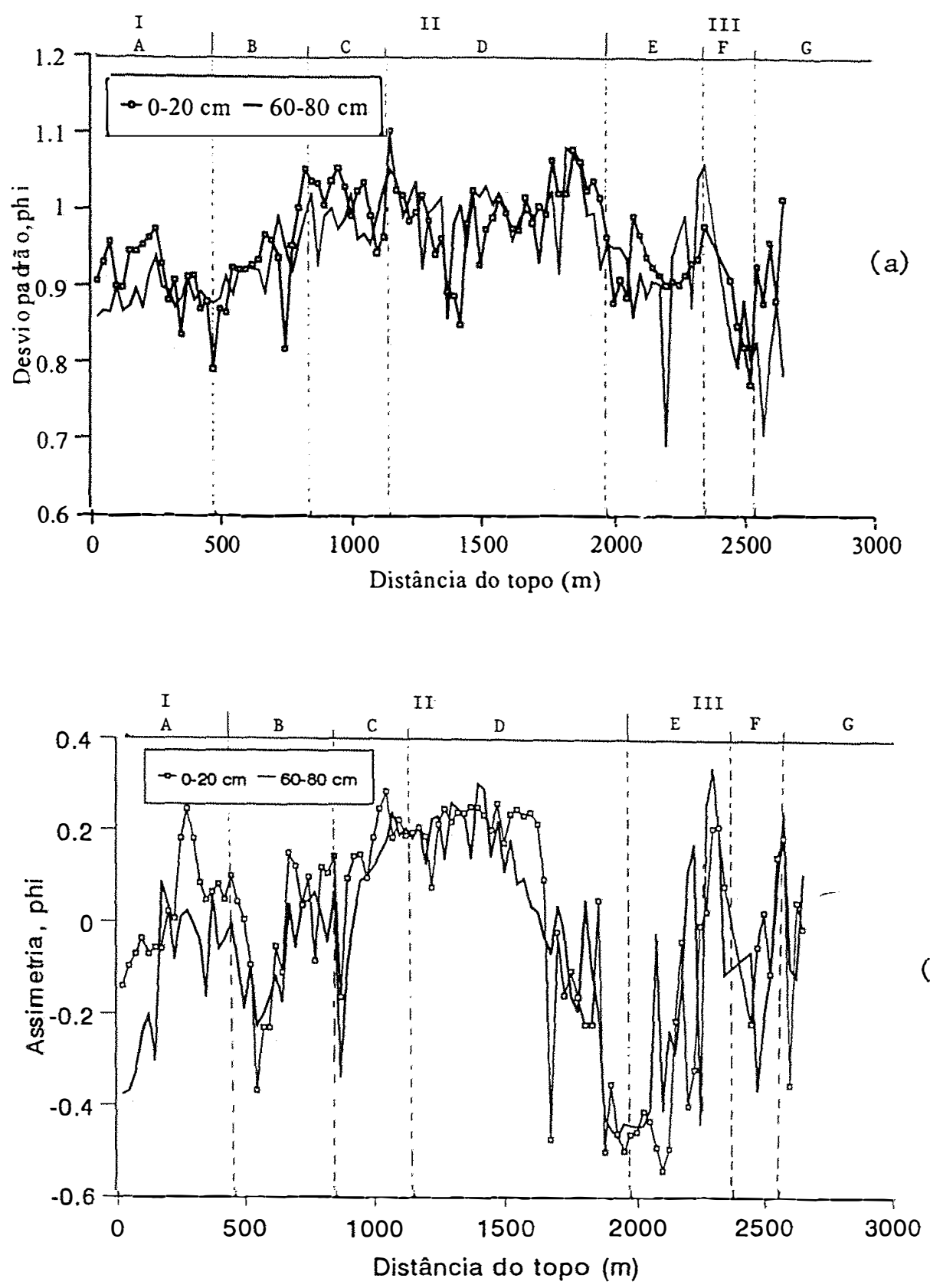

(b)

FIGURA 34. Comportamento de atributos do solo, em duas profundidades, ao longo da transeção de acordo com superfícies geomórficas (números romanos) e seus segmentos de vertente: a) Desvio padrão e b) Assimetria da distribuição granulométrica das areias nas profundidades de 0-20 e 60-80 $\mathrm{cm}$ dos solos. 

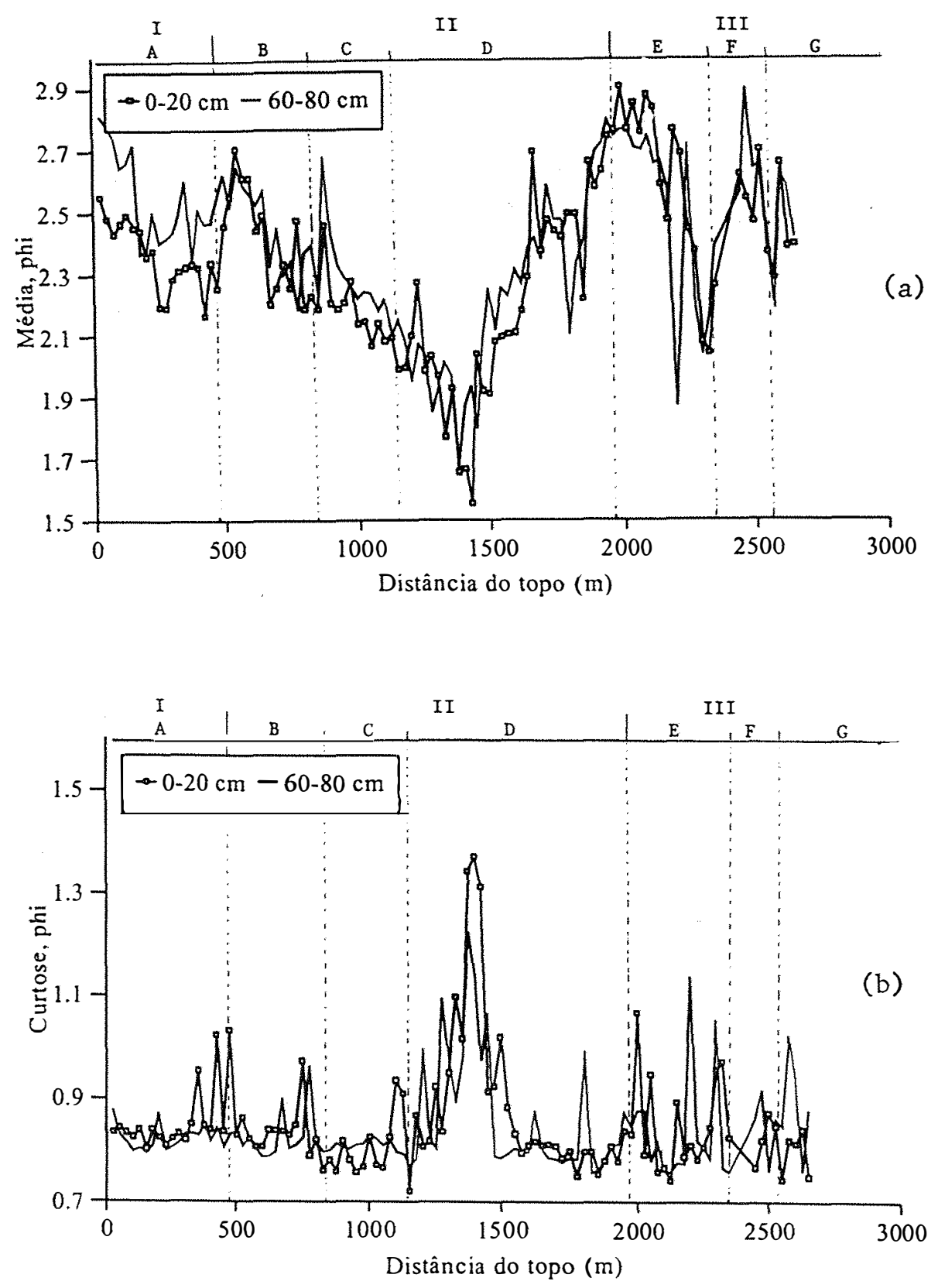

FIGURA 35. Comportamento de atributos do solo, em duas profundidades, ao longo da transeção de acordo com superfícies geomórficas (números romanos) e seus segmentos de vertente a) Média e b) Curtose da distribuição granulométrica das areias ao longo da transeção nas profundidades de 0-20 e $60-80 \mathrm{~cm}$. 
Nas unidades de vertente seguintes, ombro inferior e principalmente no sopé da superficie II, entre 850 a 1.975 metros do topo da transeção, são registrados pontos onde o desvio padrão é classificado como pobremente selecionado, com curtose leptocúrtica, e ocorrendo assimetria apresentando uma "cauda" na curva de distribuição de partículas no sentido de seus menores tamanhos (FIGURA 35b).

No segmento ombro (superfície III) o desvio padrão (FIGURA 34a) tende a diminuir (moderadamente selecionado) e a assimetria mais negativa (grosseiros) aumenta (FIGURA 34b), porém a areia muito fina tende a aumentar (FIGURA 35). A mesma tendência, mas com intensidade menor, é verificada pelos segmentos da escarpa e sopé de transporte (assimetria mais negativa, aumento da média gráfica e desvio padrão), seguida pelo inverso deste comportamento no sopé de deposição

O padrão de comportamento da distribuição do tamanho de partícula quando comparada à erodibilidade dos solos calculada pelo método de DENARDIN (1990) (QUADRO 7), nos mesmos segmentos da vertente (QUADRO 4), oferece uma visão para importantes ilações. Considera-se os dados do Quadro 7 para efeitos comparativos, sendo importante observar as tendências.

Os trabalhos clássicos de maior impacto sobre as diferentes escolas de geomorfologia baseiam-se na evolução da forma da vertente por ação dominante da erosão.

Destacam-se os trabalhos de Davis, Penck, King (YOUNG, 1972), Hack citado por DANIELS \& HAMMER (1992) ${ }^{2}$ e de Ruhe (RUHE et al., 1967). Segundo PENTEADO (1968), as vertentes são formadas sob a influência das

${ }^{1}$ YOUNG, A. Slopes. London, Songman, 1972. 288p.

${ }^{2}$ DANIELS, R.B. \& HAMMER, R.D. Soil geomorphology. John Wiley \& Sons, Inc. New York, 1992. 236p. 
propriedades dos solos, que por sua vez, condicionam a erosão. DANIELS \& HAMMER (1992) mencionam que uma paisagem inicial pode possuir uma superficie quase plana próxima a alguma linha de drenagem incipiente, não sendo obrigatoriamente, portanto, resultado direto de canais escavados em rocha dura.

QUADRO 7. Erodibilidade calculada dos solos da vertente (média dos pontos da transeção).

\begin{tabular}{ccc}
\hline $\begin{array}{c}\text { Segmentos da } \\
\text { vertente }\end{array}$ & $\begin{array}{c}\text { Unidade de } \\
\text { Mapeamento }\end{array}$ & $\begin{array}{c}\text { Erodibilidade } \\
\text { (t/ha/MJ.mm/ha.h })\end{array}$ \\
\hline A & LV & 0,006882 \\
B & LVp & 0,008027 \\
C & PV-1 & 0,010896 \\
D & PV-2 & 0,00437 \\
D & PV-3 & 0,021368 \\
E & PV-4 & 0,031339 \\
F e G & R & 0,031135 \\
H & PV-5 & 0,028207 \\
\hline
\end{tabular}

Os solos da superficie III (E, F, G e H) possuem maior grau de erodibilidade, em relação aos solos das superfícies I e II. O solo que apresenta o menor índice de erodibilidade, como tendência, (PV-2) ocorre no segmento de vertente mapeado como sopé (superficie II), caracterizando uma superficie pretérita de deposição, formada em ambiente provavelmente mais seco que o atual. Neste segmento (D), caracterizado pelo menor grau de seleção do tamanho das areias (indicado pela tendência do desvio padrão maior) (FIGURA 34a), existem vários pontos com curtose leptocúrtica, mostrando ter havido uma diferença significativa entre o selecionamento nas extremidades e na parte central da curva (FIGURA 35b) e assimetria mais positiva 
(finos), corroborado pela média gráfica menor (FIGURA 35a), porém com maior presença relativa de grosseiros que os demais segmentos.

Este conjunto de características parece indicar que houve a remoção de partículas mais finas, pela erosão diferencial, deixando as mais grosseiras, as quais tendem a se acumular na superficie, reduzindo o efeito do impacto direto das gotas de chuva, diminuindo o arraste de partículas e até mesmo o encrostamento. Este efeito pode ter contribuído para a atual maior estabilidade desta unidade de vertente. Este modelo corrobora as idéias de RESENDE et al. (1992).

Observando o encaixe da vertente atual na cota 600 metros (FIGURA 22), verifica-se que nesta mesma direção há uma tendência da diminuição do tamanho das partículas na escarpa e sopé (FIGURA 10), também expressos pelas relações areia fina/areia grossa (FIGURA 26b) e silte/argila (FIGURA 26a), podendo estar relacionado com o arenito mais fino, presente na parte mais inferior do "pacote" da formação Marília, segundo o modelo de SUGUIO (1980).

Esta observação é corroborada pelos estudos de MANZINI (1990), que através de seção colunar de 54 metros na Fazenda Paredão (correspondente ao início do ombro da escarpa na área de estudos limítrofe com o depósito neo-cenozóico), constatou que o diâmetro médio das partículas do arenito diminui do topo para a base da coluna.

Isto pode ter contribuído para o abaixamento dos níveis de base locais, e para o estabelecimento de canais tributários e principais atuais, que segundo o modelo de RUHE (1956), em sucessivos abaixamentos dos níveis de base, passaram a coordenar a erosão regressiva de encosta, até a atual forma da paisagem.

YOUNG (1972) comenta como um fato interessante Davis e Penck terem elaborado seus modelos de evolução da vertente de maneira muito semelhante, ambos baseados nos processos erosivos atuais, inspirados pelo princípio uniformitarista ou atualismo, segundo o qual os processos na paisagem não diferem, essencialmente, em natureza e intensidade, dos que atuaram em épocas anteriores, ou seja, o presente serve de modelo para conhecimento do passado. 


\subsection{Análise de agrupamento das propriedades químicas e físicas nos pontos da transeção}

O resultado da aplicação da análise de agrupamento "cluster" nos pontos da transeção, tendo como variáveis as propriedades químicas e fisicas, podem ser vistos nas FIGURAS 36 e 37 e Quadro 8.

A análise das FIGURAS 36 e 37, mostra uma boa associação entre os agrupamentos formados e as superficies geomórficas, confirmando o potencial destas para uma primeira visão geral da área, quando se pretende compartimentar a paisagem.

O dendrograma dos pontos da transeção na profundidade de $0-20 \mathrm{~cm}$ (FIGURA 36) revela que as amostras de menor semelhança entre si (maior distância euclidiana) estão agrupadas nos segmentos F, G e $\mathrm{H}$ da superficie III. Isto mostra que nestes segmentos está registrada a maior variabilidade dos parâmetros avaliados. Nos demais segmentos da vertente (superficie I e II) são formados vários grupos, porém com distância euclidiana menor (maior semelhança entre os grupos). Na profundidade de $60-$ $80 \mathrm{~cm}$, os grupos de maior variabilidade são os mesmos (F, G e H da superficie III). De maneira geral, a distância euclidiana, principalmente na profundidade de $60-80 \mathrm{~cm}$, revela que a variabilidade dos parâmetros aumenta com a distância do topo. Isto está de acordo com os maiores coeficientes de variação (CV) apresentados pelos parâmetros químicos e fisicos na superficie III (APÊNDICE 3).

O grupo formado pelos segmentos A na superficie I e B, C e D na superficie II, nas duas profundidades (FIGURAS 36 e 37), com boa porcentagem dos pontos desta área (QUADRO 8), se relaciona ao depósito neocenozóico mapeado sob essas superficies, área de ocorrência dos latossolos e podzólicos (FIGURAS 10 e 15).

Este agrupamento reflete o maior grau de similaridade entre os parâmetros químicos e físicos nesta área (menor distância euclidiana), apesar dos diferentes tipos de manejo registrados entre o topo (superficie I) e demais segmentos da vertente, identificando um ambiente mais estável, e com maior grau de similaridade.

Na superficie II, quanto ao grau de similaridade (distâncias euclidianas próximas), estão agrupadas as diferentes unidades dos solos podzólicos com gradiente 


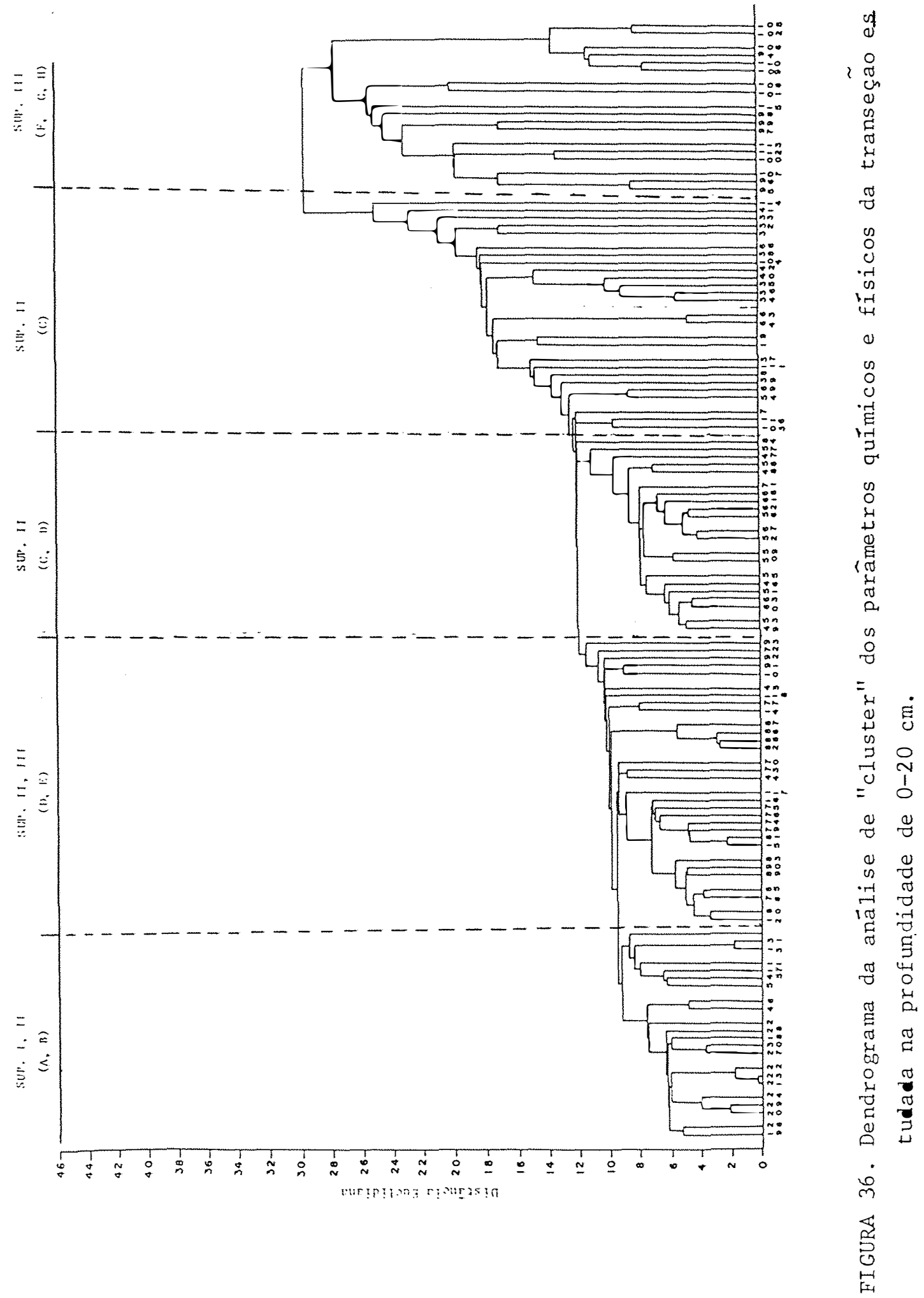




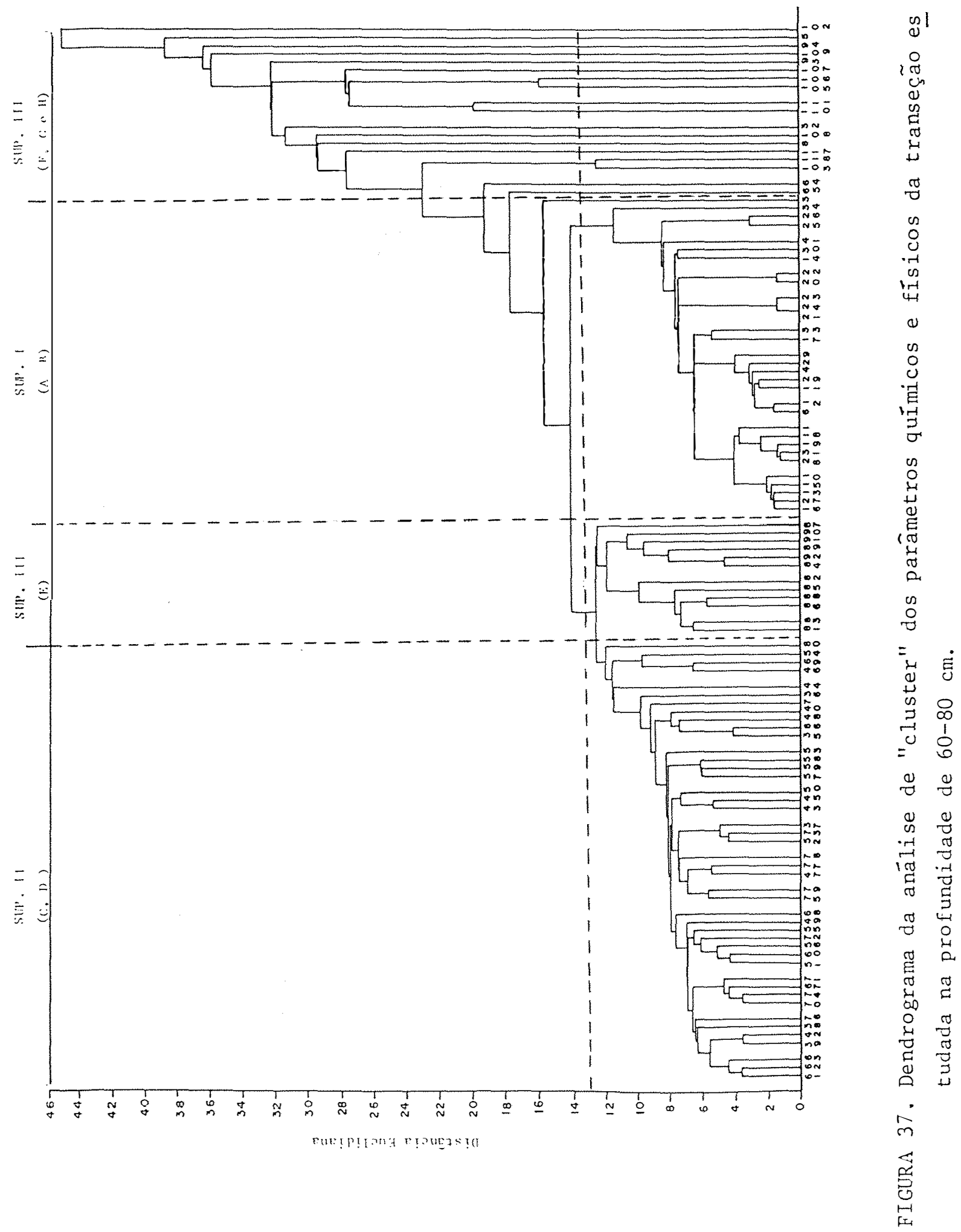


QUADRO 8. Grupos formados pela análise de "cluster" (parâmetros químicos e físicos das profundidades de $0-20 \mathrm{~cm}$ e $60-80 \mathrm{~cm}$ dos solos), unidades de mapeamento e porcentagem dos pontos correspondentes.

\begin{tabular}{lcc}
\hline $\begin{array}{c}\text { Grupos formados pela } \\
\text { análise de "cluster" }\end{array}$ & $\begin{array}{c}\text { Unidade de } \\
\text { Mapeamento }\end{array}$ & $\begin{array}{c}\text { \% dos pontos } \\
\text { correspondentes }\end{array}$ \\
\hline I(A) e II(B) & O-20 cm & 64 \\
LV, LVp & \\
II(C) & PV-1+PV-2 & 90 \\
II(D) e III(E) & PV-3 & 47 \\
& PV-4 & 86 \\
III(F,G,H) & R & 90 \\
& PV-5 & 60 \\
& $60-80$ cm & 82 \\
I(A) e II(B) & LV, LVp & \\
II(C) e II(D) & & 56 \\
& PV-1 & 84 \\
III(E) & PV-2 & 76 \\
III(H) & PV-3 & 93 \\
\hline
\end{tabular}

* Parâmetros analisados: pH CaCl 2 MO; K; Ca; $\mathrm{Mg}$; H+Al; SB; T; V; AMG (areia muito grossa); AG (areia grossa); AM (areia média); AF (areia fina); AMF (areia muito fina); S (silte); A (argila); S/A (silte/argila). 
textural abrupto, com limites claramente definidos no ombro da escarpa (segmentos $\mathrm{C}$ e D), confirmando as premissas de DANIELS et al. (1971), de que a base dos depósitos é uma importante faixa de transição entre solos distintos. As unidades PV-1, PV-2 e PV-3, encontram-se bem definidas na superficie II em ambas profundidades, participando de um agrupamento com $90 \%$ dos pontos na profundidade de $0-20 \mathrm{~cm}$, e mais de $60 \%$ dos pontos na profundidade de $60-80 \mathrm{~cm}$. A unidade $\mathrm{PV}-4$ possui mais de $85 \%$ dos pontos utilizados no seu mapeamento agrupados na parte final do segmento $\mathrm{D}$ e em toda área do segmento E (superficie III), confirmando a homogeneidade dos processos que ocorrem nos solos do ombro da escarpa, e o registro de uma superficie bem mais recente.

Para os agrupamentos formados merece destaque o modelo de unidades de vertente de DALRYMPLE et al. (1968). As unidades mapeadas na área (FIGURA 10), estão confirmadas pelos grupos formados (FIGURAS 36 e 37), enfatizando que este modelo possui um potencial de compartimentação ainda mais detalhado que o modelo de superfícies, constituindo, portanto, uma ferramenta auxiliar muito útil para estudos catenários de pedogênese, e nos levantamentos de solos.

O agrupamento I (A) e II (B) é o mais constante e mais bem expresso, tanto para os parâmetros químicos quanto físicos. Embora em superficies geomórficas diferentes, as unidades topo e ombro superior, confirmam a maior homogeneidade dos latossolos.

Para DARLYMPLE et al. (1968), o processo dominante nesta unidade de vertente é primariamente pedológico, associado com o movimento de água vertical na subsuperficie. Estes processos favorecem a lixiviação de bases e a dessilicatização desenvolvendo propriedades que caracterizam o horizonte B latossólico, como CTC $<13$ $\mathrm{cmol} / \mathrm{kg}$ de argila (com desconto para carbono orgânico) (FIGURA 18 e APÊNDICES 2 e 7), solo com presença de maior teor de gibbsita, e grau avançado de intemperização, expresso tanto pelo valor Ki como pela relação silte/argila (EMBRAPA, 1988) (FIGURA 21 e APÊNDICE 2).

Na seqüência da superficie II, onde ocorrem os solos podzólicos (PV-1, PV-2 e PV-3), coincidindo com as unidades de vertente ombro inferior da encosta (C) e sopé (D), há influência de processos geomórficos e pedológicos, condicionando eluviação 
mecânica e química pelo movimento lateral da água subsuperficial (MONIZ \& BUOL, 1982 e VIDAL-TORRADO \& LEPSCH, 1993). Estes processos, por sua vez, estão muito associados àqueles responsáveis pelos atributos diagnósticos do horizonte $\mathrm{B}$ textural, como aumento do teor de argila em relação ao horizontes A e E suprajacentes e presença de cerosidade no horizonte B (EMBRAPA, 1988) (APÊNDICE 2).

$\mathrm{Na}$ superficie III destaca-se a unidade ombro (E), como conjunto formado por muitas amostras grupadas como sendo de alta similaridade, em ambas profundidades e parâmetros avaliados (FIGURAS 36 e 37). Este segmento é descrito por DALRYMPLE et al. (1968), como ambiente de atuação de processos geomórficos e pedológicos, caracterizados por "reptação e formação de terracetes". Na área em estudo, este declive convexo facilita o aparecimento de solos muito erodidos, mapeados como PV-4. Observa-se que na profundidade de $60-80 \mathrm{~cm}$, há uma maior porcentagem dos pontos dessa unidade, presentes no agrupamento (FIGURA 37), uma vez que na profundidade de $0-20 \mathrm{~cm}$, o processo de erosão pode estar contribuindo para uma maior variabilidade (DANIELS \& NELSON, 1987).

Nos segmentos de vertente mapeados como escarpa (F) e sopé de transporte $(G)$, onde ocorre a unidade $R$, há evidências claras de que eles são controlados por processos de intemperismo e principalmente movimento de massa. Estes solos quimicamente ricos (FIGURAS 18 e 19), por estarem mais próximos do material rico em feldspatos e carbonatos, possuem argilas com atividade muito alta, elevadas relações silte/argila e areia fina/areia grossa (FIGURAS 18, 19 e 20). Nesta área é bastante comum a presença de árvores com troncos recurvados pelo deslocamento de massa, devido aos movimentos de massa provocados pelo alto declive da escarpa. Este, portanto, é um segmento bastante distinto, comprovado pela capacidade de agrupamento de seus pontos correspondentes pela análise de "cluster".

No sopé de deposição $(\mathrm{H})$, foi mapeada a unidade PV-5, comprovando a presença de processos geomorfológicos e pedológicos, segundo o modelo de DALRYMPLE et al. (1968). Este ambiente de deposição de bases e drenagem mais restrita numa determinada época do ano, condicionou o formação do horizonte A 
chernozêmico e horizonte B com saturação por bases elevada e argila de alta atividade, atributos diagnósticos do solo brunizém (APÊNDICE 2).

Apesar do modelo das nove unidades de vertente ter sido desenvolvido, em parte, nas paisagens de ambientes temperados relativamente estáveis (GERRARD, 1992), pode-se verificar, por estes resultados, que o modelo possui boa aplicação nos estudos de solo-geomorfologia em ambientes tropicais, a exemplo de outros trabalhos que o utilizaram com sucesso, como o de VIDAL-TORRADO \& LEPSCH (1993). A característica principal do modelo de DALRYMPLE et al. (1968), integrando fatores como mobilização, transporte e redeposição de materiais sobre a superficie, para algumas unidades e, para outra, destacando o movimento de água de subsuperficie como o mais importante, imprime às unidades de vertente, um caráter pedogeomórfico importante em mapeamentos em detalhe ou em áreas de maiores extensões (GERRARD, 1992).

Para CONACHER \& DALRYMPLE (1977), os processos que operam no solo podem ser observados e medidos, e neste contexto, o valor do modelo das nove unidades de vertente está em possibilitar a correlação espacial entre os processos do solo, movimento de água e gravidade. As unidades de vertente e condições hidrológicas são refletidas pelas variações de mecanismos individuais envolvidas na mobilização, transporte e deposição de materiais no solo como colóides, íons ou grãos de areia, caracterizando podzolização, gleização, "lessivage" ou salinização.

Porém DANIELS \& HAMMER (1992), acreditam que o pesquisador de campo necessita saber como a paisagem evolui no espaço e no tempo, sendo, imprescindivel adotar um modelo que considere não somente forma e processos atuantes, como também a idade relativa das diferentes partes da paisagem, para melhor entender a distribuição e comportamento dos solos. Por isso, o modelo das superficies geomórficas de RUHE (1956), utilizado por DANIELS et al. (1971), por reconhecer que nem todos os solos possuem a mesma idade, representa a base do entendimento da variabilidade do solo. Estes autores sugerem ainda, que modelos com essas características, devem ser covalidados às condições regionais, para que atue como uma moldura didática muito útil para auxiliar a transferência de conhecimentos. 
Os resultados do presente estudo confirmam essa premissa, indicando que os solos com menor grau de evolução, ocupam superficies mais rejuvenescidas, sendo a recíproca verdadeira, confirmados pelos agrupamentos formados pela análise de "cluster" (QUADRO 8).

Estes resultados também revelam a validade dos métodos estatísticos de análise multivariada e a utilização de transeções para os estudos de solos, quando se deseja entender as causas da variabilidade dos mesmos (DANIELS \& NELSON, 1987). NORRIS (1970) ressalta as vantagens dos métodos de análise multivariada em estudos e levantamentos de solos, justificados pela necessidade de síntese para entender sistemas cujas propriedades não são independentes, porém interrelacionadas em um meio complexo. Salienta ainda que esses métodos, embora utilizando técnicas matemáticas sofisticadas, na prática oferecem uma maneira muito simples de interpretação que favorece o entendimento de situações complexas na paisagem.

Desde há muito tempo, certos trabalhos reconhecem a necessidade de testar o conceito de classes de solo à partir de um maior número de propriedades, onde a similaridade entre elas fossem avaliadas com alta precisão, através de métodos de interpolação entre os pontos (HOLE \& HIRONAKA, 1960; BIDWELL \& HOLE, 1964 e RAYNER, 1966), uma vez que no conceito da classe de solo está implícito que a variação do solo possa ser caracterizada pela variação de poucas propriedades. Isto está coerente com as preocupações de BUOL (1990), quando reflete sobre as dificuldades inerentes ao entendimento e aplicações do conceito de classe de solo, cuja base está na visualização e definição do taxon completo, que existe apenas como abstração definida pelas palavras e frases de um sistema de classificação. O conjunto de taxon (taxa), caracteriza a classe taxonômica, cuja definição dos limites é igualmente abstrata.

Como verificado pela análise de "cluster", as propriedades fisicas e químicas dos corpos naturais possuem variabilidade diferenciais, constituindo agrupamentos que mostram obedecer uma lógica de ocorrência na paisagem, cujos processos controladores estão fortemente ligados à dinâmica da vertente (CONACHER \& DALRYMPLE, 1977). 
Segundo CLINE (1949), em qualquer sistema de classificação, os melhores agrupamentos são aqueles que permitem fazer o maior número e as mais precisas interpretações. Assim, sendo arbitrários, os atributos selecionados devem ser avaliados quanto ao grau de dependência de sua variabilidade em relação aos processos controladores da vertente.

Para DANIELS \& HAMMER (1992), dentre os processos da vertente, o que mais afeta as propriedades do solo é a quantidade, fluxo e distribuição sazonal de água. As oscilações na concentração de fluxos, condicionam ambientes específicos, por interferir no movimento de bases e no comportamento das argilas, podendo, por exemplo, após alguns ciclos de oxidação e redução, provocar uma destruição das mesmas, interferindo na variação da textura.

No Brasil, vários autores como e CURI \& FRANZMEIER (1984) e MACEDO \& BRYANT (1987) no Planalto Central; DEMATTÊ et al. (1991) e SCATOLINI \& MONIZ (1992) em São Paulo, e SANTANA (1984) em Minas Gerais, relatam o condicionamento de várias propriedades de solo, como o teor de ferro, sílica, bases e comportamento da cor e estrutura, ao movimento de água no sentido do declive, por ação do fluxo superficial e subsuperficial.

Nas condições deste estudo, o fluxo subsuperficial na vertente, deve possuir um padrão de comportamento similar aos preconizados por DALRYMPLE et al. (1968) e DANIELS \& HAMMER (1992). A distribuição da argila em profundidade (FIGURA 38), também possui um comportamento coerente com os diferentes segmentos de vertente mapeadas (QUADRO 4).

Os latossolos ocupam uma posição onde o movimento de água vertical favorece os processos pedogenéticos específicos, como distribuição homogênea de argila no perfil (FIGURA 38), estrutura mais desenvolvida, maior lixiviação, menor relação caulinita/caulinita+gibbsita e atividade de argila (APÊNDICE 7; QUADRO 5), relativamente aos podzólicos. Nestes solos o incremento de argila à partir de $60 \mathrm{~cm}$, associado ao maior declive, pode informar sobre o sentido e volume de concentração de fluxo de água, características desses segmentos de vertente (FIGURA 38). 


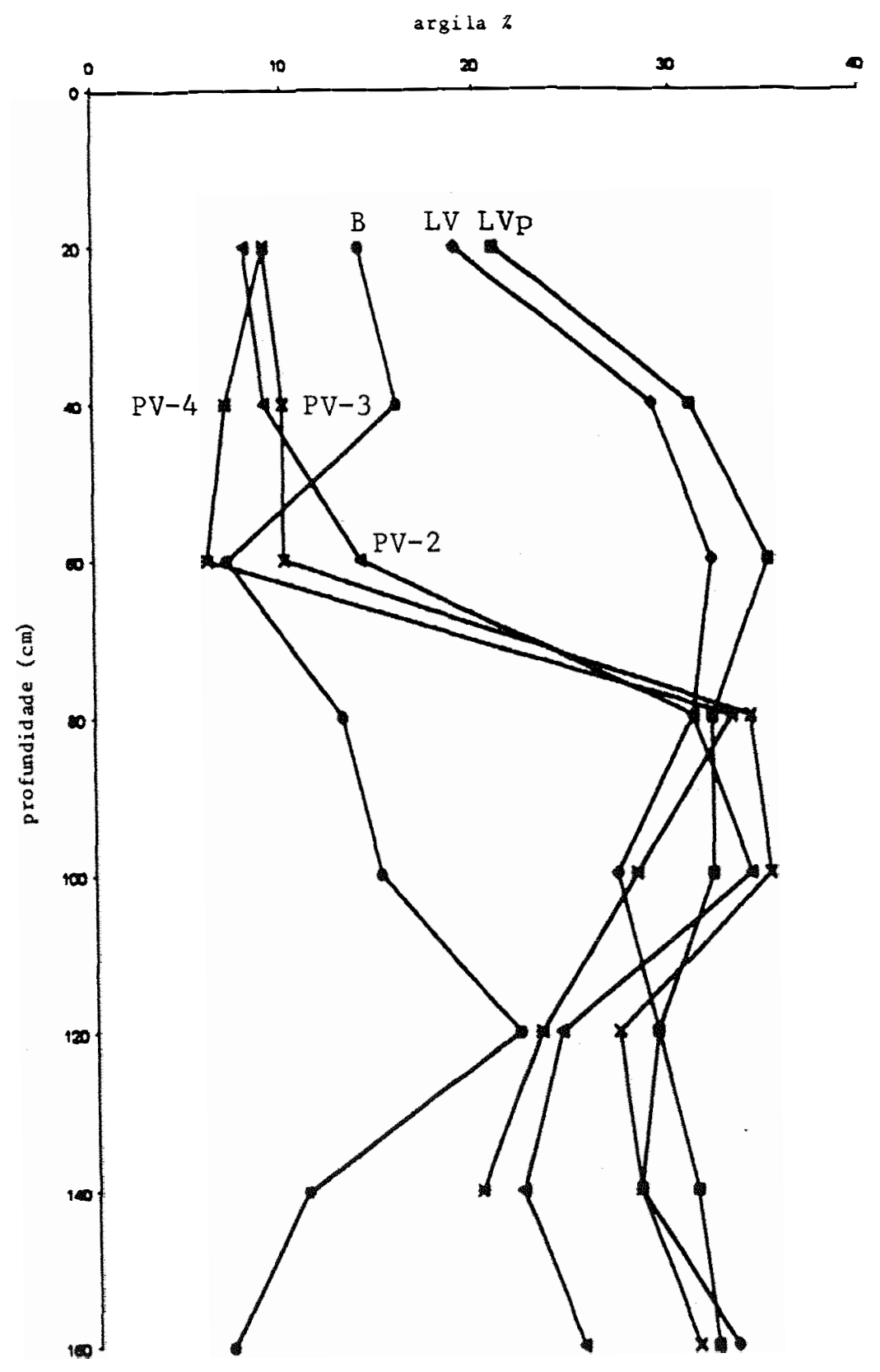

FIGURA 38. Distribuição da argila em profundidade nos perfis de solo coletados em trincheiras. 
A unidade de mapeamento PV-3, constituída por solos com horizontes $\mathrm{A}+\mathrm{E}$ espessos, ocorre na maior parte das áreas mapeadas como sopé de deposição (FIGURA 10 e 15). Estas áreas, relativamente mais planas, segundo o modelo de DANIELS \& HAMMER (1992), têm um histórico que favorece um maior tempo de concentração de fluxo de água, quando comparadas com áreas sensivelmente mais declivosas. Isto é corroborado pela análise micromorfológica (APÊNDICE 4), onde foi constatada, nesta única posição da superficie II, a presença de ferriargilãs como sintoma de argiluviação mais intensa. Assim o máximo desenvolvimento do horizonte Bt na superficie II foi atingido no seu segmento relativamente mais plano.

O solo PV-4, situado no ombro da escarpa (superficie III), com declividade mais acentuada e horizonte A mais erodido, possui a máxima expressão da segregação de ferro, indicação de hidromorfismo temporário muito acentuado. O grupo de alta similaridade formado pela análise de "cluster" (FIGURAS 36 e 37), revela que os processos são fortemente definidos e homogêneos neste segmento.

Portanto, o reconhecimento da classe de solo e sua representação em unidades nos mapas, são mais seguros, quando antes são avaliados o comportamento de várias propriedades dos "corpos naturais" ao longo de segmentos cuidadosamente definidos por critérios geomorfológicos, com processos contemporâneos e idade relativa praticamente comprovados, o que também representa a base para transferência de conhecimentos.

\subsection{Locação estatística dos limites do solo}

Nas FIGURAS 39 a 42 são apresentados os resultados da locação estatística ("split moving-window") para algumas propriedades fisicas, químicas dos solos e cotas obtidas pelo levantamento topográfico realizado nos pontos da transeção.

Este método apresentado por WEBSTER (1973) têm como objetivo principal a avaliação da variação de propriedades do solo em uma determinada direção (transeções), de maneira que se possa visualizar os limites entre agrupamentos que têm um mínimo de variância de suas propriedades. Assim, o método examina a transeção 
através de uma série fixa de determinados grupos de pontos adjacentes ("janelas") que se movem através de toda extensão dos pontos amostrados, cujas médias de determinados tributo são sucessivamente comparadas ao longo da seqüência, calculando-se os valores estatísticos do teste t. Estes valores de $t$, quando mais elevados, mostram mudança espacial na propriedade observada, indicando limites de regiões de áreas mais homogêneas, condicionadas por determinados processos controladores da formação do solo.

Para este estudo escolheu-se uma "janela" com intervalo de quatorze pontos. Este intervalo foi escolhido com base em uma série de testes, utilizando vários outros intervalos. O resultado gráfico, para "janelas" de intervalo maior ou menor, não altera a visualização dos limites pelos valores mais elevados de teste $t$ que aparecem, na forma gráfica como picos. Apenas aumenta ou diminui os "ruídos", que são as intensidades (tamanho) dos picos de menor importância. Estes resultados concordam com os de WEBSTER (1973). Assim, para a "janela 14", o princípio do método é a execução da média aritmética dos pontos em dois segmentos, sete primeiros pontos, e a média aritmética dos sete pontos subseqüentes, o teste $t$ é realizado comparando essa média com a correspondente à janela subsequente (no caso iniciando no $2^{\circ}$ ponto) e assim por diante até o final da transeção.

De modo geral, estes resultados mostram a dependência espacial diferenciada das propriedades dentro de uma unidade de mapeamento (LV), e entre duas diferentes unidades de mapeamento (LV para PV ou C para B). Observa-se ainda um comportamento diferencial das propriedades dentro de uma mesma unidade de mapeamento, quando esta ocorre em diferentes superficies geomórficas.

WANG (1982) menciona que a maioria das propriedades dos solo varia gradualmente ao longo da paisagem. Entretanto, os limites do solo (linha divisória) no mapa de solo é visualizada antes como uma "zona de transição" do que uma linha. A largura desta área de transição é controlada principalmente pela natureza da paisagem. WILDING \& DREES (1983) ressaltam que cada vez mais cresce a utilidade dos levantamentos de solos, e com isso a necessidade em termos de precisão dos limites das 

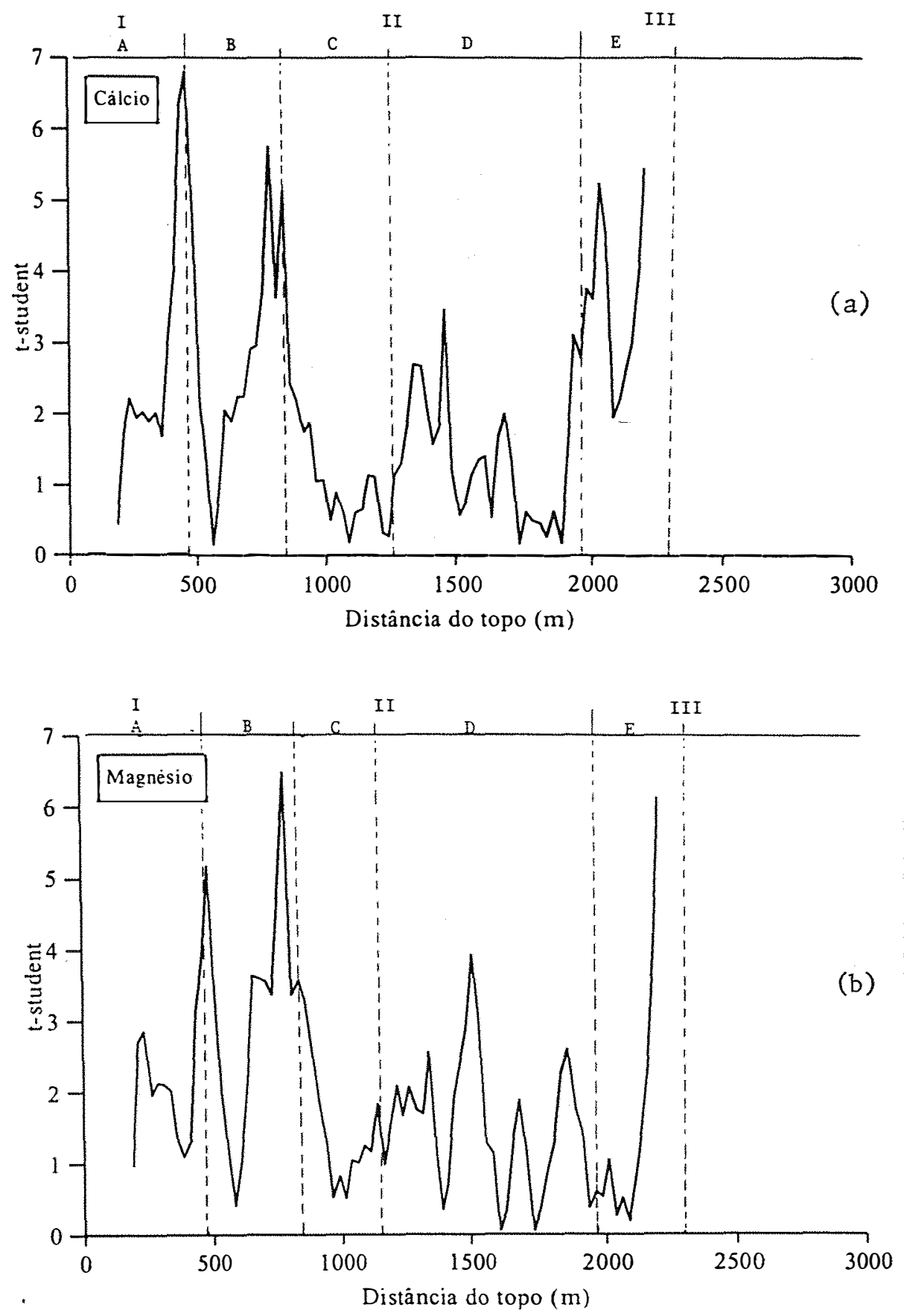

FIGURA 39. Resultados do "split moving windows" (a) para cálcio e (b) magnésio da camada de 60-80 cm dos solos em relação as superficies geomórficas (I, II e III) e segmentos de vertente (A, B, C, D e E) ao longo longo da transeção. 

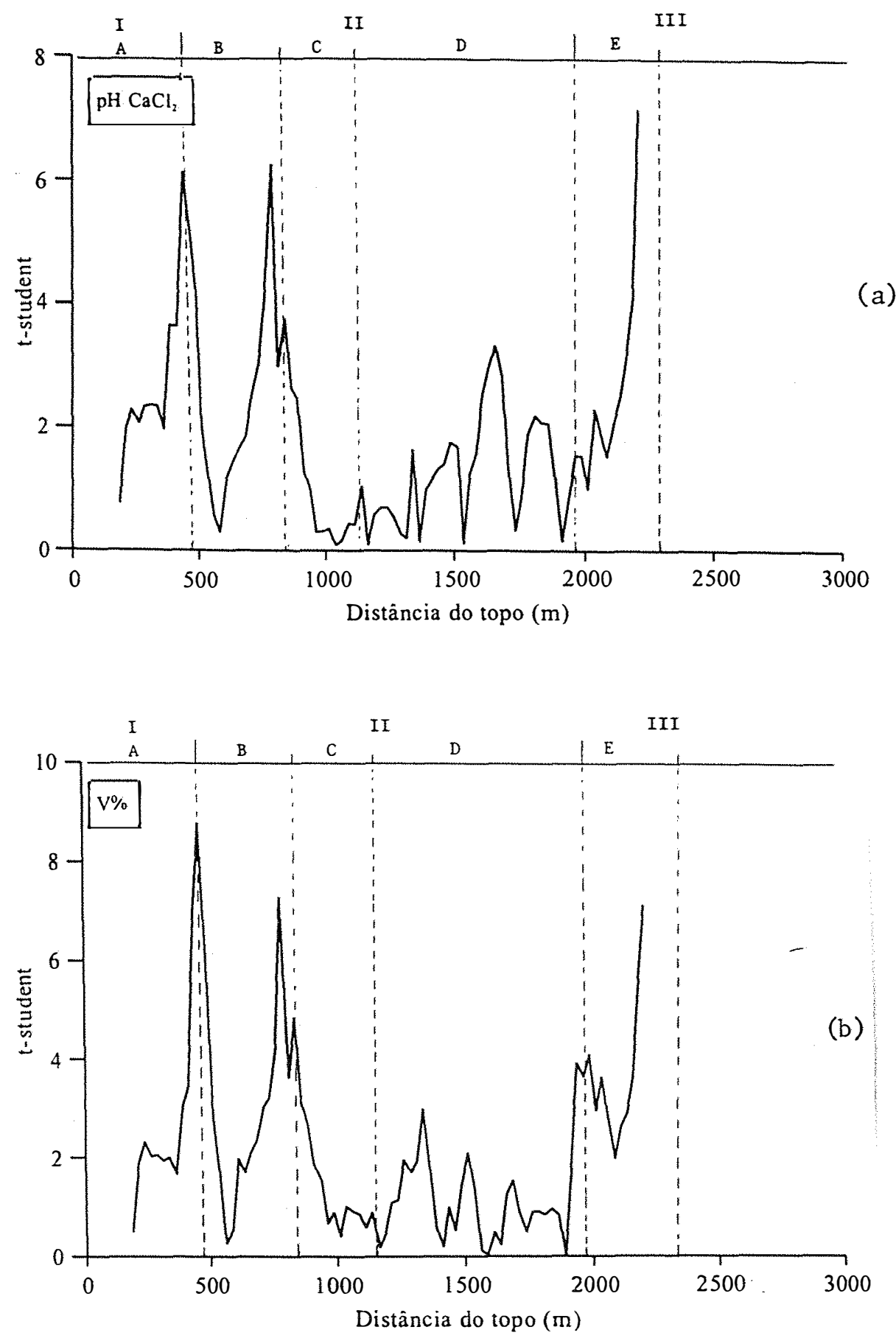

FIGURA 40. Resultado do "split moving windows" (a) para $\mathrm{pH} \mathrm{CaCl}_{2}$ e (b) $\mathrm{V} \% \mathrm{da}$ camada de $60-80 \mathrm{~cm}$ dos solos em relação as superficies geomórficas (I, Il e III) e segmentos de vertente (A, B, C, D e E) ao longo da transeção. 

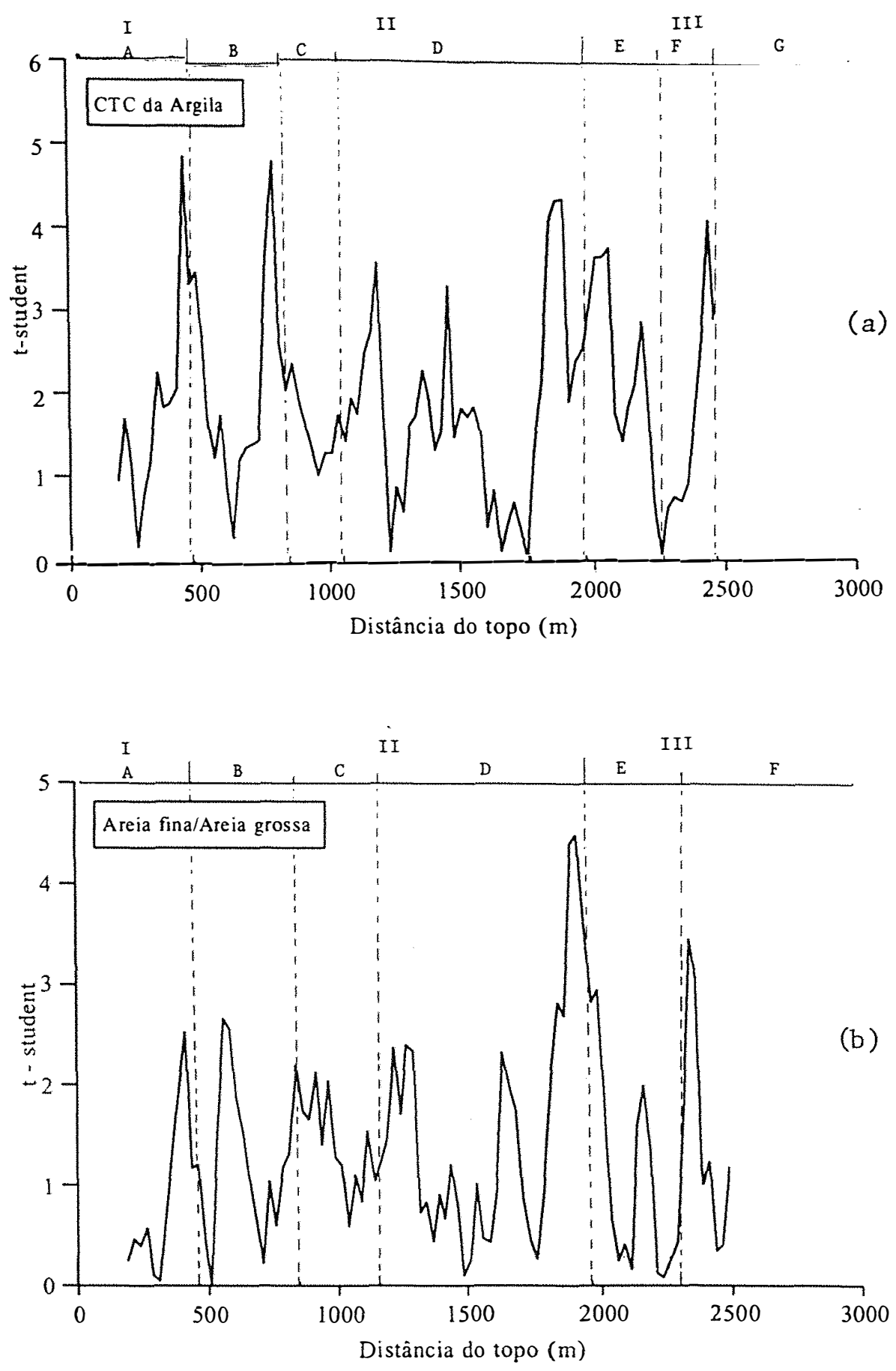

FIGURA 41. Resultado do "split moving windows" (a) para a CTC da argila e (b) relação areia fina/areia grossa na camada de $0-20 \mathrm{~cm}$ dos solos em relação as superficies geomórficas (I, II e III) e segmentos da vertente encosta ( $A, B, C, D$ e E) ao longo da transeção. 

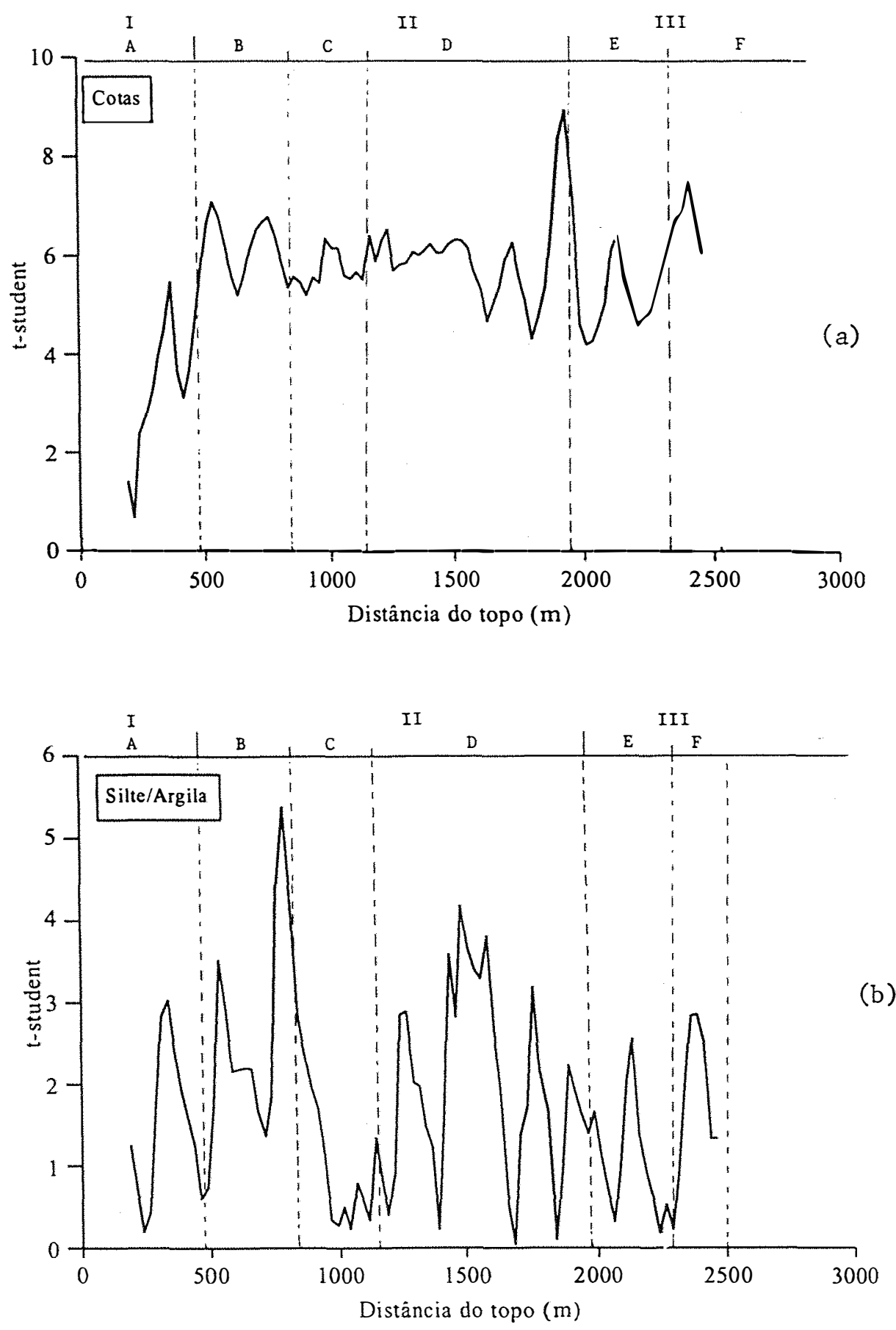

FIGURA 42. Resultado do "split moving windows" (a) para os valores de cotas e (b) relação silte/argila do perfil altimétrico na camada de $0-20 \mathrm{~cm}$ dos solos em relação as superficies geomórficas (I, II e III) e segmentos da vertente (A, B, C, D e E) ao longo da transeção. 
classes de solos, ou de entender a variabilidade de suas propriedades. A aplicação do "split moving windows" é bastante adequada para este fim.

O resultado da locação estatística das cotas (FIGURA 42a), através de seus maiores valores, ressalta os limites entre as superficies I e II, que pelo mapeamento ocorre a 475 metros da origem da transeção, e os limites entre as superficies II e III, que ocorre à 1.975 metros. Pode-se assim confirmar do método de DANIELS et al. (1971), ao preconizar reconhecimento das superficies atuais do terreno através das "quebras" de declive (ou "Knickpoints"). Porém para as unidades de DALRYMPLE et al. (1968), o método possui uma precisão ainda maior, para perceber sensiveis mudanças nas superficies atuais do terreno. Assim na superficie II, os limites entre as unidades de vertente $B$ e $C$ são melhor expressos, embora não muito coincidentes com os limites do mapeamento; porém os limites entre os segmentos $\mathrm{D}$ e $\mathrm{E}$ (pretérito sopé e ombro), e F e G (escarpa e sopé de transporte), são muito precisos em relação aos limites do mapeamento, indicando que as unidades cujos limites são os mais facilmente reconhecidos, pertencem às superficies mais novas ou segmentos menos estáveis. Portanto, os modelos quando aplicados de maneira conjunta, são muito eficientes, atendendo as expectativas de VIDAL-TORRADO (1994), quando menciona a maior capacidade de detalhamento do modelo de DALRYMPLE et al. (1968), que em trabalhos de campo, poderia ser associado às superficies geomórficas de DANIELS et al. (1971).

O maior valor do teste $t$ na FIGURA 42a assinala a transição entre a superficie, possivelmente de idade pleistocênica, e superficie III, holocênica (LEPSCH et al., 1977a). É também o limite entre segmentos de vertente bastante distintos, pretérito sopé e ombro da escarpa, onde processos peculiares, como maior concentração de fluxo, influenciam a morfologia diferenciada de solos, o que também se relaciona com limite do depósito cenozóico encontrado na área. Nesta mesma posição, estão registrados valores de teste $t$ mais elevados para as relações areia fina/areia grossa (FIGURA 4lb), indicando uma possível descontinuidade litológica, devido a possíveis implicações de instabilidade da camada mais superficial de superficies mais recentes onde movimentos de massa estão em atual e constante atividade. 
Nas Figuras 39 e 40, observa-se para todos os parâmetros químicos estudados, que os maiores valores de "t student" estão muito próximos dos limites de solos estabelecidos através da morfologia. Os limites entre os latossolos e podzólicos estão bem expressos. Esta transição está reforçada pelo elevado valor do teste $t$ da relação silte/argila (FIGURA 42b) nesta mesma posição, à 850 metros da origem da transeção.

Cálcio e magnésio (FIGURA 39) possuem um comportamento muito semelhante, e mostram que sua variabilidade na transeção é dependente dos processos que ocorrem nos segmentos da vertente. A mesma tendência foi observada para saturação por bases, $\mathrm{pH}$ em $\mathrm{CaCl}_{2}$ e CTC da argila (FIGURAS 40 e 41), confirmando a estreita correlação entre estes parâmetros.

Não se pode descartar a influência das diferenças em manejo, relacionadas ao uso de fertilizantes minerais, sobre os valores de teste $t$ apresentados. Os solos das posições de topo da superfície I, por vários anos encontram-se sob cultivo de cana-de-açúcar, e os solos do ombro superior de encosta estão sendo cultivados com manga. Embora ocorra aí somente latossolos, diferenças na calagem e adubação podem estar contribuindo para acentuar as diferenças de teste $t$, além das que registram diferentes segmentos na encosta.

LEPSCH et al. (1994), estudando as propriedades químicas de solos sob agricultura e vegetação natural no estado de São Paulo, concluíram que, após muitos anos de cultivo, vários horizontes subsuperficiais $(60-100 \mathrm{~cm})$ de vários solos apresentaram um acréscimo de bases trocáveis (principalmente cálcio) e de saturação por bases. Resultados similares de carreamento de cálcio e magnésio para camadas subsuperficiais em função do manejo também foram observados por QUAGGIO et al. (1982) e NATALE \& COUTINHO (1994).

Por outro lado, os altos valores de teste $t$ de propriedades como CTC da argila e relação silte/argila (FIGURAS 41 a e 42b), coincidindo com os limites de solos e segmentos de vertentes mapeados no campo, reitera o potencial do modelo de DARLYMPLE et al. (1968), indicando que pequenas variações no terreno, podem ser 
suficientes para indicar mudanças nos processos de formação do solo o que, conseqüentemente, influencia propriedades importantes.

Modelos como este são instrumentos úteis por serem de simples aplicação e permitir um reconhecimento e avaliação da variabilidade de propriedades do solo, e conseqüentemente de seu potencial produtivo. Neste sentido, WILDING \& DREES (1983) ressaltam que o entendimento da variabilidade espacial está ligado ao poder preditivo dos modelos de paisagem. Estes modelos devem ser testados com base em propriedades que reflitam variações de parâmetros dificeis de serem avaliados, como retenção de água e condutividade hidráulica. DANIELS \& HAMMER (1993) reforçam a importância do comportamento hidrológico, influenciando as propriedades nos diversos segmentos da vertente, afirmando que não se pode pensar em solo e água como unidades separadas do sistema da paisagem.

A proximidade entre os limites obtidos à partir da morfologia dos solos, e unidades de vertentes, refletidas pelo teste $t$ das propriedades estudadas, revela que 0 modelo de vertentes ao propor a caracterização dos seus segmentos através de processos contemporâneos, tais como mobilização, transporte, deposição, sugere uma grande proximidade com os quatro processos de formação do solo, propostos por SIMONSON (1959): adição, perda, translocação e transformação. Para JUNGERIUS (1985) ${ }^{3}$, é relativamente fácil encontrar relações do controle geomórfico com cada um dos processos pedológicos. Este autor menciona que, no trabalho de Wooldrige (1949) que é considerado como uma das primeiras publicações formais focalizando estes aspectos em periódico de assuntos pedológicos, já foi verificado uma grande ênfase em relação à visão associada destes processos.

A maior ou menor proximidade relativa dos limites das superficies geomórficas com unidades de mapeamento do solo, chama atenção para os cuidados na utilização de fotografias aéreas para estabelecimento de limites entre unidades de

${ }^{3}$ JUNGERIUS, P.D. Soil and geomorphology. Catena, Amsterdan, 6:1-18, 1985. (Supplement, 6). 
mapeamento. Para o caso em estudo, as aerofotos propiciaram a visualização apenas dos limites das superficies geomórficas I, II e III (FIGURA 10) que não necessariamente coincide com as unidades de solo (FIGURA 15).

Na Figura 43 o comportamento dos parâmetros químicos dos solos nas superficies apresenta valores próximos nas superficies I e II, com diferença significativa para a superficie III, indicando a possibilidade de ocorrência de duas ou três classes de solos. As relações silte/argila e areia fina/areia grossa, corroboram este comportamento (FIGURA 45).

O comportamento das mesmas propriedades nos segmentos de vertente (FIGURAS 23a, 23b e 26a) permite a visualização dos segmentos com menor variabilidade (APÊNDICE 2), e uma maior capacidade de previsão da ocorrência dos solos.

Assim os valores de $\mathrm{pH}, \mathrm{V} \%$, CTC e soma de bases (FIGURA 43), aumentam da superficie I para a superficie III, porém apresentando comportamento peculiar, devido aos processos diferenciais dos segmentos de vertente. Os teores de silte aumentam da superficie I para a III, bem como sua variabilidade, ao contrário da argila cujos teores diminuem neste sentido.

WEBSTER \& BECKETT (1968), WEBSTER \& WONG (1969) e JARVIS (1969), estudando unidades de paisagem identificadas somente através de fotografias aéreas, concluíram que grande parte destas unidades possuía uma capacidade preditiva das propriedades do solo muito limitada. A variabilidade das propriedades dos solos nestas unidades era por demais elevada, quando comparada a estudos que utilizaram métodos geomorfológicos mais detalhados (LEPSCH et al., 1977a; WRIGHT, 1979 e VAN DEN BROEK et al., 1981). Segundo os autores, a razão da discrepância entre os resultados é a escala de análise nas quais as unidades de paisagem foram definidas. Salientam que as unidades identificadas à partir de aerofotos são freqüentemente áreas compostas por outras menores, especialmente associadas. E sua amalgamação resulta em variabilidade interna considerável em termos de solo e outras propriedades. Vários autores (WILDING \& DREES, 1983 e DANIELS \& NELSON, 

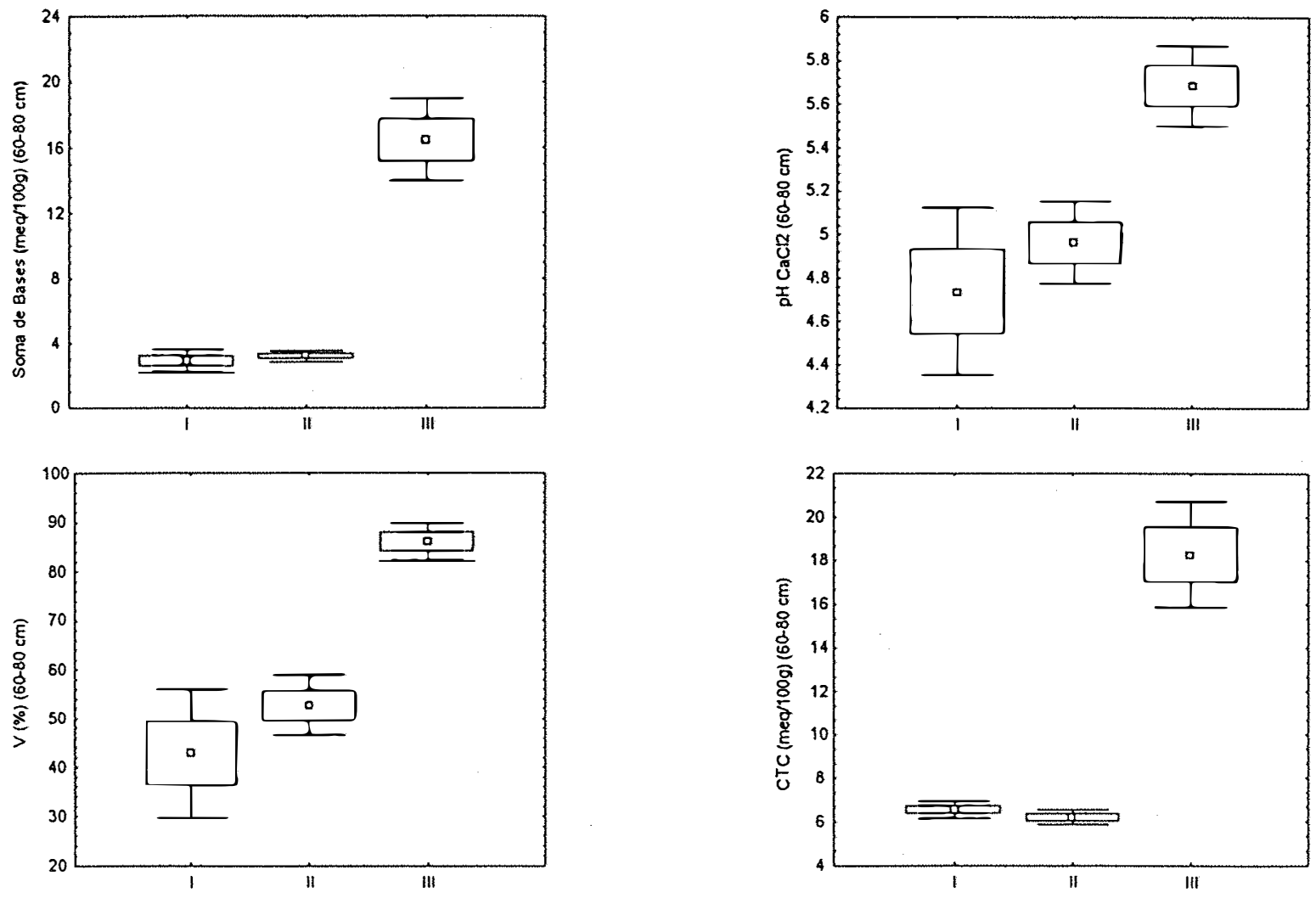

FIGURA 43. Médias (quadrado pequeno) com respectivos intervalos de confiança (média \pm $S \bar{x}$ e média $\pm 1,96 S \bar{x}$ ) das propriedades químicas dos solos de ocorrência na superficie geomórficas. 

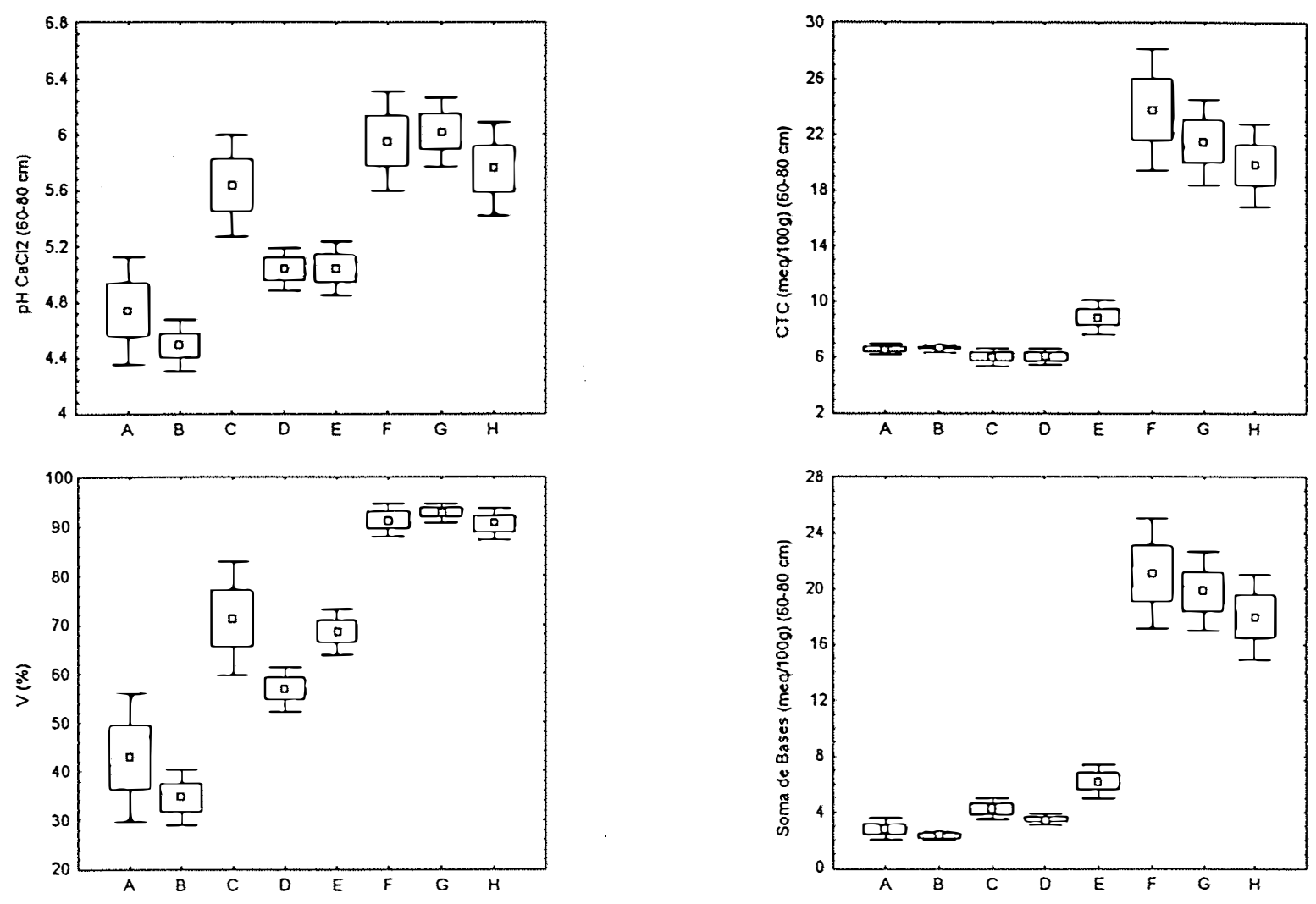

FIGURA 44. Médias (quadrado pequeno) com respectivos intervalos de confiança (média \pm $\mathrm{S} \bar{x}$ e média $\pm 1,96 \mathrm{~S} \overline{\mathrm{x}}$ ) das propriedades químicas dos solos de ocorrência nos segmentos de vertente. 

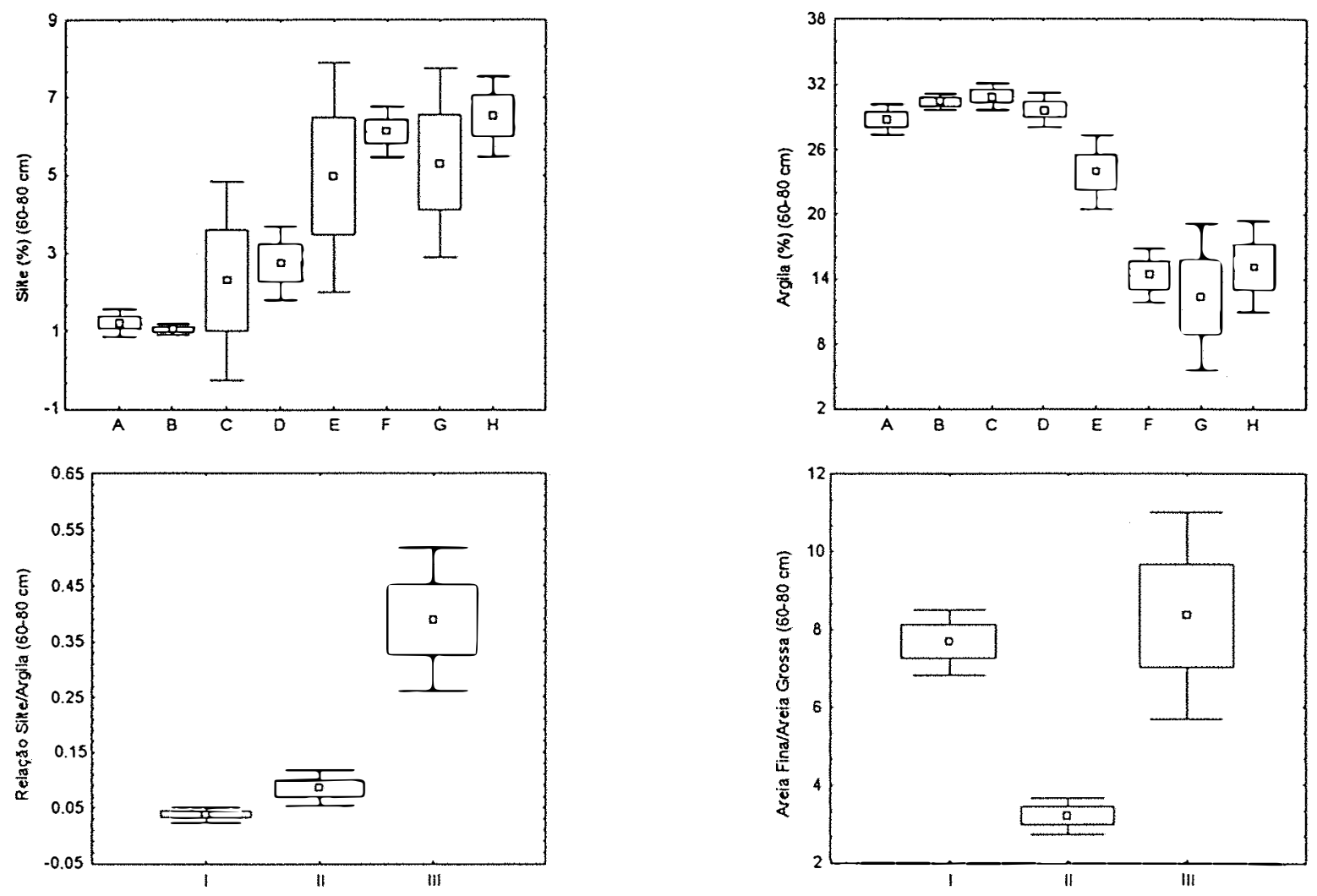

FIGURA 45. Médias (quadrado pequeno) com respectivos intervalos de confiança (média \pm $S \bar{x}$ e média $\pm 1,96 S \bar{x}$ ) das propriedades fisicas dos solos de ocorrência nos segmentos de vertente (acima) e na superficies geomórficas (abaixo). 
(1987), mencionam que a variabilidade sistemática natural é muito dependente de elementos geomórficos. Alguns salientam que no futuro, será de grande importância a integração dos conhecimentos pedológicos e geomorfológicos para o entendimento da variabilidade.

Pode-se vislumbrar, portanto, o grande potencial do "split moving windows" para testar os limites da cartografia convencional de solos, pela facilidade e relativa precisão em estabelecer os limites de corpos naturais definidos taxonomicamente que se deseja mapear.

Segundo CLINE (1977), a $7^{\text {a }}$ aproximação do "Soil Taxonomy" (ESTADOS UNIDOS, 1975) priorizou a atenção no conceito central ou indivíduo típico de cada "taxon", cujos limites não foram definidos, mas percebidos através da maior ou menor similaridade ao conceito central. A atenção ficou restrita, portanto, à composição interna de cada "taxon". Assim, mapeadores de solos necessitam de grande experiência para tomada de decisão dos limites de similaridade, e as medidas de inclusões nas unidades de mapeamento ficam submetidas a julgamentos pessoais. A "Soil Taxonomy" (ESTADOS UNIDOS, 1975) definiu limites de classe em termos quantitativos, o que força a atenção para os limites dos "taxa", que são mais dificeis de serem visualizados. Assim, pode-se entender que "taxon" e unidade de mapeamento, muitas vezes identificados pelo mesmo nome, são dois conceitos diferentes.

ARNOLD (1983) salienta que a representação dos "taxa" que ocorrem na natureza tem sido feita por diferentes nomes pelos cientistas. Este autor, tem sugerido a adoção de uma ponte à partir da estrutura de um "taxon" do esquema de classificação do solo, com os limites projetados de variabilidade de ocorrência natural na paisagem.

Neste contexto, o reconhecimento das unidades de vertente como auxiliares ao estabelecimento dos limites dos solos, é imprescindível.

\subsection{Modelo da gênese e evolução dos solos na paisagem}

Pelos resultados obtidos neste estudo pôde-se perceber que os solos na paisagem não ocorrem ao acaso, mas obedecem uma lógica de ocorrência que é 
controlada por processos históricos e contemporâneos da paisagem. Os processos de pedogênese, portanto, estão ligados principalmente ao tempo que os materiais ficam expostos aos agentes do intemperismo, que por sua vez é controlado pelo relevo, que é a forma do solo, ou pedoforma.

\subsubsection{Gênese dos latossolos da área}

Os eventos neo-tectônicos registrados na área por MANZINI (1990), conjuntamente com episódios relacionados com fases de morfogênese em climas semiáridos pretéritos (BIGARELLA et al., 1965), são de grande importância para compreenção da ocorrência dos solos na paisagem da região. Na Figura 46, é mostrado o que se considera por hipótese, em decorrencia ao modelo de MANZINI (1990).

Neste contexto, observa-se que os blocos rebaixados, "grabens", (FIGURA 46a), condicionam o carreamento de materiais para o seu interior, formando assim um depósito colúvio-aluvionar, sobre a formação Marília, ocorrido provavel-mente em início de fase de clima semi-árido (logo após fase úmida). Esta área teria assim ficado preservada da ampla erosão regional devido as condições de alta permeabilidade, e portanto resistência à erosão, do depósito sobre a formação Marília.

Os solos que atualmente ocupam esta superficie, apresentam propriedades típicas destes solos pedogenéticamente mais evoluidos. A avaliação estatística das areias na transeção mostra que há uma tendência de homogeneidade do tamanho das partículas no segmento correspondente a estes solos (FIGURA 34); a mesma avaliação para o diâmetro das areias coletadas através de amostragem profunda, revela a mesma homogeneidade até vários metros de profundidade (FIGURAS 11, 12 e 13); além de baixa relação silte/argila (FIGURA 21).

Resultados das análises químicas das amostras em profundidade revelam que são solos muito lixiviados e dessilicatizados (APÊNDICE 6); baixo $\mathrm{pH}$ e baixa saturação por bases foram registrados também nos horizontes superficiais destes solos (FIGURA 41), além de acidez trocável relativamente elevada (FIGURA 17). 


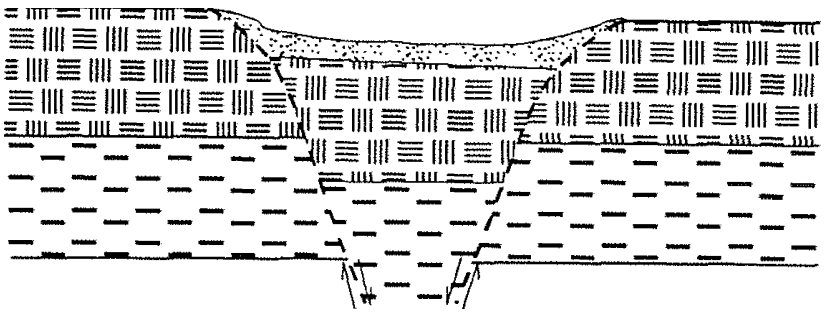

(a)

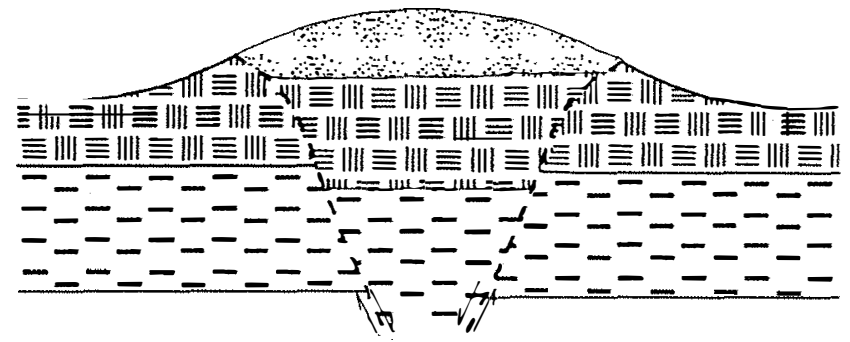

(b)

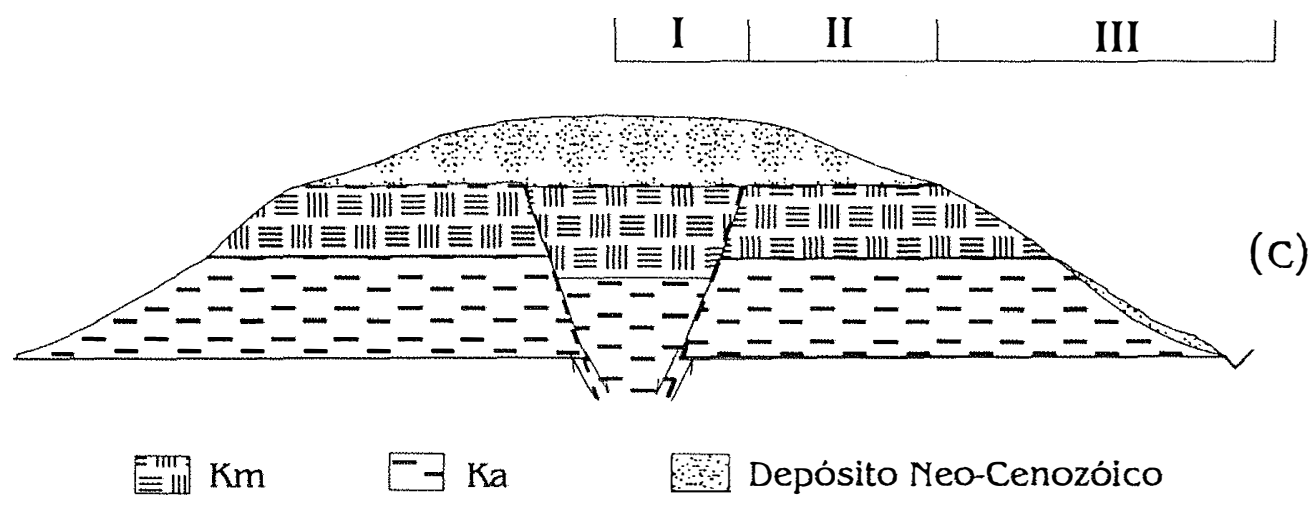

FIGURA 46. Modelo hipotético de evolução da paisagem com base nos eventos neotectônicos e episódios relacionados com fases de morfogênese em clima semi-áridos pretéritos $(\mathrm{Km}=$ Formação Marília, $\mathrm{Ka}=$ Formação Adamantina; $a, b$ e c = Diferentes épocas de ocorrência dos eventos). 
A morfologia de campo apresenta-se muito característica para latossolos, no horizonte A blocos médios a muito pequenos, que se desfazem em grânulos, e no horizonte Bw2 granular muito pequena com aspecto maciço poroso "in situ" (APÊNDICE 2). A bioturbação é bastante evidente, podendo ser observada através do "empacotamento" de microagregados (FIGURAS 27a e b. Estes possuem grande estabilidade quando envolve argilas e óxidos, SANTOS et al. (1989), constituindo um forte impedimento para ocorrer a argiluviação, NETTLETON et al. (1987). VIDALTORRADO (1994) menciona que o fato desses empacotamentos de microagregados ocorrerem em solos de superficies mais antigas, pressupõe que foi necessário muito tempo para se formarem.

Vários autores concordam que a presença de plasma isótico (FIGURA 27. APÊNDICE 1) e de microagregados dominando o horizonte $\mathrm{Bw}$ caracterizando latossolos presentes em superficies antigas (LEPSCH et al., 1977; SANTOS et al., 1989; VIDAL-TORRADO \& LEPSCH, 1993; VIDAL-TORRADO, 1994). A mineralogia predominantemente caulinítica, com presença de gibbsita, e valores $\mathrm{Ki}$ em torno de 1,5, além da baixa atividade das argilas (QUADRO 6; APÊNDICE 7), corroboram a pedogênese avançada desses solos desenvovidos do depósito neocenozóico.

As propriedades químicas e fisicas desses solos, situados no topo da paisagem, quando analisados conjuntamente através da análise de cluster, demonstram um alto grau de similaridade, formando um grupo muito homogêneos e com limites claramente definidos (FIGURAS 36 e 37).

A superficie I apresenta uma transição lateral para superficie II bastante nítida. O teste estatístico "split moving windows" para os valores de cotas do perfil altimétrico (FIGURA 42), revelam mudanças na topografia do terreno em posições quase idênticas aos limites apresentados pelo mapeamento de superficies geomórficas. 


\subsubsection{Gênese dos podzólicos}

A maioria dos podzólicos da área ocorre na superficie II e ombro da superficie III. A possível explicação para a formação dessa superficie decorre em sequência à formação dos depósitos colúvio-aluvionares no interior dos blocos rebaixados "grabens" (FIGURA 14a e 14b).

A mudança climática, provavelmente para semi-árido, posterior ao abaixamento dos níveis de base regional, teria estabelecido as redes de drenagem sobre as superficies dos "horsts", em materiais areníticos carbonatados, os quais teriam sido desgastados em proporção maior que os antigos topos dos "grabens" recobertos por depósitos superficiais de maior permeabilidade que os arenitos, o que teria promovido o fenômeno de inversão de relevo (FIGURA 46b e 46c). Os compartimentos de encostas, adjacentes ao atual alto topográfico preservado (FIGURA 46b e 46c), teriam sido formados durante fases pretéritas de climas úmidos alternados com semi-áridos (BIGARELLA et al., 1965).

O baixo tectônico é o atual alto topográfico, caracterizado na área pelas superficie I e II. Estas superficies relativamente planas, preservadas da erosão regional, teriam permitido a exposição do material colúvio-aluvionar por um tempo suficiente para atuação dos processos de transformação e remoção, caracterizado por intemperismo intenso e lixiviação de sílica e bases.

Pela Figura 46b, percebe-se que o abaixamento dos níveis de base regionais, possivelmente direcionaram a erosão regressiva de encosta, contribuindo assim, para o estabelecimento da superfície II, em cotas pouco inferiores à superficie I, porém com declives pouco acentuados até os limites com o ombro da escarpa. Nesta posição está o limite do depósito neo-cenozóico mapeado na área por MANZINI (1990).

A variação no declive desse segmento da vertente, contribuiu para a mudança do fluxo lateral de água, desencadeando os mecanismos favoráveis para transformação lateral dos horizontes $\mathrm{B}$ latossólicos para horizontes $\mathrm{B}$ texturais desenvolvidos sobre os depósitos neo-cenozóicos. Apesar da ocorrência de cutãs ter sido evidenciada com maior expressão nos solos do sopé da superficie II, a presença do 
gradiente textural abrupto em todos os podzólicos dessa superficie, confirma o modelo de MONIZ \& BUOL (1982) onde o fluxo lateral subsuperficial cresce à partir dos limites dessa superficie, desenvolvendo uma camada cada vez mais adensada por ação mecânica deste fluxo.

A mudança do fluxo lateral é indicada através dos resultados do teste estatístico "split moving windows" para algumas propriedades dos solos (FIGURAS 39, 40 e 41), em posições limítrofes dos latossolos para latossolos podzólicos, e destes para podzólicos com gradiente textural abrupto.

A explicação para a formação do horizonte $\mathrm{Bt}$ em relevo mais íngreme adjacente aos latossolos, está também de acordo com o modelo de LEPSCH (1977). Observando o Quadro 6, verifica-se, com base na relação argila/Fe $\mathrm{f}_{\mathrm{d}}$, que o horizonte $\mathrm{A}$ dos podzólicos apresentam teores relativamente maiores de ferro. Em outras palavras a argila dos horizontes $\mathrm{A}$ e $\mathrm{E}$ tem mais ferro que a do horizonte Bt. A água que se move nos horizontes A e E possui menor demanda de oxigênio devido a maior atividade biológica, assim os óxidos de ferro desses horizontes podem ser reduzidos e removidos do perfil. Em conseqüência ocorre a migração preferencial de argila silicatada com ausência de ferro, para formação do horizonte Bt.

CASTRO (1989), estudando a gênese desses podzólicos na região de Marília,SP, concorda com o modelo de LEPSCH (1977b), ao afirmar que a remoção do ferro no horizonte A, desestabiliza os agregados colocando a argila em suspensão, confirmado pelo desmantelamento de estruturas porfiricas na altura da transição $\mathrm{AB}$ e Bt.

Em decorrência do que foi exposto, esses podzólicos apresentam gradiente textural abrupto e menor expressão dos microagregados, predominam blocos subangulares pequenos a médios, alguns que se desfazem em grânulos no horizonte A. Todos apresentam cerosidade no horizonte $\mathrm{B}$, e presença de fendas de atividade biológica na transição dos horizontes $\mathrm{E}$ e $\mathrm{Bt}_{1}$ (APÊNDICE 2).

O plasma é isótico, à semelhança dos latossolos, e observa-se um aumento da presença de ferriargilã no sentido da jusante da encosta. A morfoscopia e também a mineralogia das argilas desses podzólicos da superficie II, são muito 
homogêneas (FIGURAS 28 e 29). Essas características reforçam a origem comum desses solos, sobre os depósitos neo-cenozóicos.

O dendrograma da análise de cluster mostra um agrupamento distinto, formado por esses solos na superficie II, porém com grau de similaridade muito próximo ao agrupamento formado pelos latossolos na superficie I (FIGURAS 36 e 37).

\subsubsection{Gênese dos solos menos desenvolvidos}

Os solos que ocorrem na superficie III possuem, comprovadamente, menor grau de desenvolvimento, o que está de acordo com a idade dessa superfície. A transição entre esta e a superficie II é fácil d e ser percebida no campo. Os resultados do teste de locação estatística revelam que seus limites estão confirmados por todas as propriedades analisadas (FIGURAS 39, 40 e 43).

No PV-4, localizado no ombro, é marcante a presença de lamela no horizonte E. Essas lamelas foram referidas por BERG (1984) e BOND (1986) como consequêencia da rápida migração de argilas, justificado por um possível desequilíbrio físico-químico da reação do solo provocado pela retirada da cobertura vegetal nativa, dando início ao processo de argiluviação.

A presença de mica e plasma massépico, no PV-4 do ombro, e esmectita no cambissolo e brunizem do sopé, estão de acordo com a elevada CTC da argila desses solos. A morfoscopia é diferenciada à partir desta posição da encosta até o sopé. A relação $\mathrm{Fe}_{\mathrm{o}} / \mathrm{Fe}_{\mathrm{d}}$ é maior no brunizem, indicando o predominio de formas de oxidos de ferro pouco cristalinas, sintoma da presença de uma fase de drenagem mais restrita durante o ano nesta posição da vertente. Estas características confirmam a presença de solos com baixo grau de desenvolvimento.

Portanto, as evidências de atividades neo-tectônicas levantadas por MANZINI (1990) aliada às teorias de preservação de superficie (RUHE 1969) e variações climáticas de BIGARELLA et al. (1965), além de observações da paisagem atual, justificam a ocorrência de depósitos neo-cenozóicos sob a superficie I e II, atual alto topográfico e correlativa ao antigo "graben" tectônico (FIGURA 46c); bem como o 
esculturamento de toda paisagem ao seu redor sendo a superficie II provavelmente remanescente de pedimento oriundo de clima semi-árido, e a escarpa e arredores (superficie III) o correspondente à erosão holocênica em condições de clima úmido. 


\section{CONCLUSÕES}

1. A ocorrência e distribuição dos solos na paisagem, mostraram-se muito coerentes com as condições tempo-dependente das superficies geomórficas. Assim os solos com maior grau de desenvolvimento (latossolos) ocupa a superficie mais antiga, estando os solos com B textural na superficie intermediária e os solos menos desenvolvidos na superficie mais jovem, a exemplo do encontrado por vários autores. As superficies geomórficas constituem-se, portanto, em excelente método didático para auxilio nos trabalhos de campo para separação de unidades pedológicas e subsídio ao melhor entendimento dos processos de pedogênese;

2. A compartimentação de superficies geomórficas segundo os respectivos segmentos de vertente mostrou-se como um bom complemento para explicar variabilidade dentro da superficie. A associação deste método de compartimentação de vertente, com aquele de superfícies geomórficas, constitui-se em um importante instrumento para os trabalhos de levantamentos de solos, principalmente na etapa de campo;

3. O método de análise de "cluster" mostrou-se muito eficiente para separar as superficies geomórficas, e agrupar as classes de solos segundo o grau de similaridade de suas propriedades químicas e físicas, favorecendo dessa maneira o rápido entendimento de relações complexas entre solos e elementos da vertente;

4. O método do "split moving windows" foi bastante sensível para auxiliar na identificação de limites tanto das unidades de mapeamento dos solos como dos compartimentos geomórficos; permitindo avaliar pequenas variações do declive suficientes para influenciar propriedades importantes e alterar processos do solo; 
5. Os latossolos e podzólicos das superficies I e II apresentaram características micromorfológicas e mineralógicas semelhantes. O plasma isótico, trama gefúrica, e grãos arredondados a subarredondados, apresentando uma morfoscopia muito parecida e; a mineralogia caulinítica, demonstram que esses solos possuem desenvolvimento pedogenético muito próximos, refletindo a origem comum sobre os depósitos neo-cenozóicos;

6. A compreensão de eventos neo-tectônicos, conjuntamente com episódios relacionados com fases de morfogênese em climas semi-áridos pretéritos, foram importantes para compreensão da relação dos solos com as superfícies geomórficas e elementos de encosta. 


\section{REFERÊNCIAS BIBLIOGRÁFICAS}

Ab'SABER, A.N. Os baixos chapadões do o este paulista. São Paulo, USP/Instituto de Geografia, 1969. 8p. (Geomorfologia. 17).

ALHO, D.R. Mineralogia e gênese de solos litólicos da região de Jaboticabal, SP. Jaboticabal, 1993. 71p. (Trabalho de Graduação - Faculdade de Ciências Agrárias e Veterinárias de Jaboticabal/UNESP).

ALMEIDA, M.A.; STEIN, D.P.; MELO, M.S.; BISTRICHI, C.A.; PONÇANO, W.L.; HASUI, Y.; ALMEIDA, F.F.M. Geologia do oeste paulista e áreas fronteiriças dos Estados de Mato Grosso do Sul e Paraná. In: MESA REDONDA - "A FORMAÇÃO BAURU NO ESTADO DE SÃO PAULO E REGIÕES ADJACENTES", São Paulo, 1980. Coletânea de trabalhos e debates. São Paulo, Sociedade Brasileira de Geologia/Núcleo de São Paulo, 1980. p.31-43.

ALMEIDA, F.F.M. de. Fundamentos geológicos do relevo paulista. Boletim do Instituto Geográfico e Geológico, São Paulo, (41):169-263, 1964.

ALMEIDA, J.A.; KLANT, E.; KAMPF, N. Origem do contraste textural de um podzólico vermelho-amarelo da Planície Costeira do Rio Grande do Sul. In: XXV CONGRESSO BRASILEIRO DE CIÊNCIA DO SOLO, III, Viçosa, 1995. Resumos expandidos. Campinas, Sociedade Brasileira de Ciência do Solo, 1995. p.1635-6. 
ALOISI, R.R. Caracterização de algumas famílias de solos do município de Jaboticabal, FCAVJ/UNESP. Jaboticabal, 1973. (Doutorado - Faculdade de Ciências Agrárias e Veterinárias/UNESP).

ARID, F.M.; BARCHA, S.F.; PIERUCETI, J.A. Drenagem e traços tectônicos na região Norte-Ocidental do Estado de São Paulo. Geociências, São Paulo, 2:65-74, 1983.

ARNOLD, R.W. Concepts of soils and pedology. In: WILDING, L.P. \& SMECK, N.E., ed. Pedogenesis and soil taxonomy. I. Concepts and interactions. New York, Elsevier Science, 1983. p.107-40.

BALL, D.F. \& WILLIAMS, N.M. Variability of soil chemical properties in two incultivated brown earths. Journal of Soil Science, Oxford, 19:379-91, 1968.

BARCELOS, J.H.; SOUZA FILHO, E.E.; FÚlFARO, V.J.; LANDIM, P.M.B.; COTTAS, L.R.; WU, F.T.; GODOY, A.M. A formação Itaqueri: um exemplo de tectofáceis. In: SIMPÓSIO REGIONAL DE GEOLOGIA, 4, São Paulo, 1983. Atas. São Paulo, Sociedade Brasileira de Geologia, 1983. p.245-52.

BEADOU, A. Expression micromorphologique de la microagrégation et de l'illuviation dans certains sols ferralitiques centraficans et dans les sols hydromorphes associés. Cahiers ORSTOM. Sér. Péd. 10(4):357-71, 1972.

BENNEMA, J. The calculation of CEC for 100 graus clays (CEC 100) with correction for organic carbon. In: FAO. Report to the government of Brazil on classification of Brazilian soils. Rome, FAO, 1966. 83p. (FAO, EPTA, 2197).

BERG, R.C. The origin and early genesis of clay bands in yoceth ful sand soils along Lake Michigan, USA. Geoderma, Amsterdam, 32:45-62, 1984. 
BIDWELL, O.W. \& HOLE, F.D. An experiment in the numerical classification of some kansas soils. Soil Science Society of American Proceedings, Madison, 28:263-8, 1964.

BIGARELLA, J.J.; MOUSINHO, M.R.; SILVA, J.X. da. Considerações a respeito da evolução das vertentes. Boletim Paranaense de Geografia, Curitiba, (16/17):85$116,1965$.

BIGARELLA, J.J. \& ANDRADE, G.O. de. Contribution of to the study of the Brazilian quaternary. In: GEOLOGICAL SOCIETY OF AMERICA. Internacional studies on the quaternary. New York, 1965. p.443-51. (GSA. Special Paper, 84).

BIRKELAND, P.W. Soils and geomorphology. New York, Oxford University Press, 1984. 372p.

BLAKE, G.R. Particle density. In: BLACK, C.A., ed. Methods of soil analysis. Madison, American Society of Agronomy, 1965. v.1, p.371-3.

BOND, W.J. Illuvial band formation in a laboratory column of sand. Soil Science Society of America Journal, Madison, 50(2):265-7, 1986.

BRANDT NETO, M. O Grupo Bauru na região centro-norte do Estado de São Paulo. 1984. (Doutorado-Instituto de Geociências/USP).

BRASIL. Ministério da Agricultura. Comissão de Solos. Levantamento de reconhecimento dos solos do Estado de São Paulo. Rio de Janeiro, 1960. 634p. (Boletim, 12).

BREWER, R. Fabric and minerals analysis of soil. New York, Krieger Publ. 1976. 482p. 
BUOL, S.W. \& ESWARAN, H. The micromorphology of oxisols. In: INT. WORK. MEET. SOIL MICROMORPH. 5., Granada, 1978, Proceedings. v.1., p.325-47.

BUOL, S.W. Suelos tropicales: classificación y características. In: SALINAS, J.G.; GOULEY, L.M. Sorgo para suelos ácidos. Cali, CIAT, 1990. p.49-62.

BUOL, S.W.; HOLE, F.D.; McCRACKEN, J. Soil genesis and classification. Iowa Stat. University Press, Ames. 404p. 1980.

BUTLER, B.E. Periodic phenomena in landscape as a basis for soil studies. Sidney, CSIRO, Canberra, 1959. 19p. (Aust. Soil Publ., 14).

CAMERON, D.R.; NYBORG, N.; TOODGOOB, J.A.; LAVERT, D.H. Accuracy of field sampling for soil tests. Canadian Journal of Soil Science, Ottawa, 51:165-75, 1971.

CAMPBELL, J.B. Spatial variation of sand content and $\mathrm{pH}$ within single contignores delineations of two soil mapping units. Soil Science Society of America Journal, Madison, 42:460-4, 1978.

CARMO, D.N.; CURI, N.; RESENDE, M. Caracterização e gênese de latossolos da região do Alto Paranaíba (MG). Revista Brasileira Ciência do Solo, Campinas, 8(2):235-40, 1984.

CARVALHO, A. Solos da região de Marília - Relação entre a pedogênese e a evolução do relevo. São Paulo, 1976. 163p. (Doutorado - Faculdade de Filosofia, Letras e Ciências Humanas/USP). 
CASTRO, S.S. Sistemas de transformação pedológica em Marília, SP: B latossólicos e B texturais. São Paulo, 1989. 274p. (Doutorado - Faculdade de Filosofia, Letras e Ciências Humanas/USP).

CHRISTOFOLETTI, A. \& QUEIROZ NETO, J.P. Os sedimentos da serra de Santana, SP. Boletim Paranaense de Geografia, Curitiba, (18-20):231-245. 1966.

CHRISTOFOLETTI, A. Geomorfologia. Ed. Edgard Blucher Ltda. São Paulo, 1982. $188 \mathrm{p}$.

CIPRA, J.E.; BIDWELL, D.A.; WHITNEY, D.A. \& FEYERHERM, A.N. Variations with distance in selected fertility measurements of pedons of western Kansas ustoll. Soil Science Society America Proceedings, Madison, 36:111-15, 1972.

CLINE, M.G. Priciples of soil sampling. Soil Science, Baltimore, 58:275-88, 1944.

CLINE, M.G. Historical highlights in soil genesis, morphology and classification. Soil Science Society American Journal, Madison, 41:250-253, 1977.

CLINE, M.G. Basic principles of soil classification. Soil Science, Baltimore, 58:275-288. 1949.

COELHO, R.M.; LEPSCH, I.F.; MENK, J.R. Relações solo-relevo em uma encosta com transeção arenito-basalto em Jaú (SP). Revista Brasileira Ciência do Solo, Campinas, 18(1):125-37, 1984.

CONACHER, A.J. \& DALRYMPLE, J.B. The nine unit landsurface model, an approach to pedogeomorphic research. Geoderma, Amsterdam, 18:1-154, 1967. 
CURI, M. \& FRANZMEIER, D.P. Topossequence of oxisols from the Central Plateau of Brazil. Soil Science Society of America Journal, Madison, 51(1):153-8, 1984.

DALRYMPLE, J.B.; BLONG, R.J.; CONACHER, A.J. A hipothetical nine unit land surface model. Zeitschrift für Geomorphologie, Berlin, 12(1):60-76, 1968.

DANIELS, R.B. \& HAMMER, R.D. Soil geomorphology. New York, John Wiley, 1992. 236p.

DANIELS, R.B. \& NELSON, L.A. Future variability and productivity: Future developments. In: BOERSMA, L.L, Future Developments in soil Science Research. Madison, Soil Science Society of America Journal, 1987. p.279-91.

DANIELS, R.B.; GAMBLE, E.E.; CADY, J.F. The relation between geomorphology and soil morphology and genesis. Advances in Agronomy, Madison, 23:51-87, 1971.

DAY, P.R. Particle fractionation and particle - size analysis. In: BLACK, C.A., ed. Methods of soil analysis. Madison, American Society of Agronomy, 1965. v.1, p.545-66.

DE BIASI, M. Carta de declividade de vertente: Confecção e utilização. Geomorfologia, São Paulo, (21):8-13, 1977.

DECHEN, S.C.F.; DEMATTÊ, J.L.I.; MARCONI, A. Caracterização granulométrica e mineralógica de três perfis de solos desenvolvidos do arenito Bauru no Estado de São Paulo. Revista Brasileira Ciência do Solo, Campinas, 18(3):499-511, 1994.

DEMATTÊ, J.L.I; MARCONI, A.; SPAROVEK, G.; VIDAL-TORRADO, P. Estimativa da evolução do intemperismo mediante ganhos e perdas de íons numa 
sequüencia de solos desenvolvidos de diabásio e influenciados pela drenagem em Piracicaba, SP. Revista Brasileira Ciência do Solo, Campinas, 15(1):69-73, 1991.

DENARDIN, J.E. Erodibilidade do solo estimada por meio de parâmetros físicos e químicos. Piracicaba, 1990. 113p. (Doutorado-Escola Superior de Agricultura "Luiz de Queiroz"/USP).

EMPRESA BRASILEIRA DE PESQUISA AGROPECUÁRIA. Serviço Nacional de Levantamento e Conservação de Solos. Manual de métodos de solo. Rio de Janeiro, 1979.

EMPRESA BRASILEIRA DE PESQUISA AGROPECUÁRIA. Serviço Nacional de Levantamento e Conservação de Solos. Critérios para distinção de solos e de fases de unidade de mapeamento: normas em uso pelo SNLCS. Rio de Janeiro, 1988. 67p. (Documento, 11).

ESCHENBRENNER, V. Contribution des termites à la micro-agrégation des sols tropicaux. Cahiers ORSTOM. Sér. Péd., 22(4):397-408, 1986.

ESPINDOLA, C.R. \& CARVALHO, W.A. Relações entre a natureza dos solos e suas posições na paisagem na Bacia do Capivara. Botucatu (SP). Científica, São Paulo, 14(1/2):29-37, 1986.

ESTADOS UNIDOS. Department of Agriculture. Soil survey staff: keys to soil taxonomy. Ithaca, Cornell University, 1992. 280p. (SMSS. Technical Monograph, 8).

ESTADOS UNIDOS. Department of Agriculture. Soil Survey Staff. Soil Survey Staff. Washington, 1951. 503p. (Agriculture. Handbook, 18). 
ESTADOS UNIDOS. Department of Agriculture. Soil Survey Staff. Soil taxonomy. Washington, 1975. 754p. (Agriculture Handbook, 436).

ESWARAN, H. \& SYS, C. Argillic horizon in LAC soils: formation and significance to classification. Pedologie, Ghent, 29:175-90, 1979.

FAO. A framework for land evaluation. Rome, 1976. 72p. (FAO. Soil Boletim, 32).

FEDOROFF, N. \& ESWARAN, H. Micromorphology of ultissols. In: DOUGLAS, L.A. \& THOMPSON, M.L., ed. Soil micromorphology and soil classification. Madison, Soil Science Society of America Journal, 1985, p.17-47.

FITZPATRICK, R.W. \& SCHWERTMANN, V. Al-substituted goethite an indicator of pedogenic and other wrathering environments in South Africa. Geoderma, Amsterdam, 27:335-47, 1982.

FOLK, R.L. \& WARD, W.C. Brazas river bar: a study on the significance of grain-size parameters. Journal of Sedimentary Petrology, Tulsa, 27:3-26, 1957.

FÚlFARO, J.V.; SANTOS, A.R.; SAAD, A.R. A estrutura de Pirati-ninga, SP. In: SIMPÓSIO REGIONAL DE GEOLOGIA, 4, São Paulo. 1983. Resumos. São Paulo. Sociedade Brasileira de Geologia, 1983.

FÚLFARO, V.J. \& BARCELOS, J.H. Grupo Bauru no Triângulo Mineiro: uma nova visão litoestratigráfica. In: SIMPÓSIO DE GEOLOGIA DO SUDESTE, 2., São Paulo, 1991. Atas. São Paulo, SBG, 1991. p.59-66.

FÚlfaro, V.J. \& BJORNEBERG, A.J.S. Geologia do Estado de São Paulo In: Solos do interior de São Paulo. São Carlos: ABMS. Escola de Engenharia, 1993. p.1-42. 
FÚlFARO, V.J. \& SUGUIO, K. O cenozóico paulista: gênese e idade. In: CONGRESSO BRASILEIRO DE GEOLOGIA, 28. Porto Alegre, 1974, Anais. Porto Alegre, SBG, 1974. v.3, p.91-101.

FÚlFARO, J.V.; SAAD, A.R.; SANTOS, M.V.; VIANNA, R.B. Comparti-mentação e evolução tectônica da Bacia do Paraná. Revista Brasileira de Geociências, São Paulo, 12(4):590-610, 1982.

GERRARD, J. Soil geomorphology: present dilemmas and future challeuges. In: Geomorphology: Amsterdam, 24:61-84, 1993.

GERRARD, J. Soil geomorphology: And integration of pedology and geomorphology. London, Chapman \& Hall, 1992. 269p.

GUALBERTO, V.; RESENDE, M.; CURI, N. Química e mineralogia de Latossolos, com altos teores de ferro, da Amazônia e do Planalto Central. Revista Brasileira de Ciência do Solo, Campinas, 11(3):245-52, 1987.

HALL, G.F. Pedology and geomorphology. In: Pedogeneses and soil taxonomy. I Concepts and Interactions. New York, Elsevier Sci. 1983. p.117-40.

HALL, G.F. \& OLSON, C.G. Predicting variability of soils from landscape models. In: MAUSBACH, M.J. \& WILDING, L.P. Spatial variabilities of soils and landforms. Madison, 1993. p.9-24.

HARTUNG, S.; SCHEINOST, S.A.; AHRENS, R.J. Scientific methodology of the National Cooperative Soil Survey. In: SPATIAL variabilities of soils and landforms. Madison, Soil Science Society America, 1993 p.29-48. 
HASUI, Y.; HARALYI, N.L.E.; SAAD, A.R.; CAMPANHA, V.A.; HANZA, V.M.; GALLI, V.A.; FRANGIPANI, A.; PULEGHINI, G.P. Compartimentação estrutural e evolução tectônica do Estado de São Paulo. São Paulo, IPT, 1989. 2v. (IPT. Relatório, 27).

HOLE, F.D. \& HIRONAKA, M. An experiment in ordination of some soil properties. Soil Science Society of America Proceedings, Madison, 24:309-12, 1960.

INSTITUTO DE PESQUISAS TECNOLÓGICAS DO ESTADO DE SÃO PAULO Mapa geomorfológico do estado de São Paulo. Esc. 1:1.000.000. São Paulo, IPT/DMGA, 1981. 2v.

ISBELL, R.F. The argilic horizon concept and its application to the classification of tropical soils. In: CONFERENCE ON CLASSIFICATION OF TROPICAL SOIL. Kuala Lumpur, 1980. Proceedings. Kuala Lumpur, Malasyan Society of Soil Science, 1980. p.150-57. 1980.

JARVIS, M.G. Terrain and soils in north Berkshire. Geographical Journal, 135:398403, 1969.

JIMENEZ RUEDA, J.; DEMATTÊ, J.C.I. Solos originados de lamitos da formação Marília (Grupo Bauru) da região de Monte Alto, SP. Revista Brasileira Ciência do Solo, Campinas, 12(2):161-70, 1988.

JONG VAN LIER, Q. \& VIDAL-TORRADO, P. Phi: Programa de microcomputador para análise estatística da granulometria de sedimentos. Revista Brasileira de Ciência do Solo, Campinas, 16:275-81, 1992.

JUNGERIUS, P.D. Soils and geomorphology. Catena, Amsterdan, 6 (suppl. 6):1-18, 1985. 
KÄMPF, N.; RESENDE, M.; CURI, N. Iron oxides in Brazilian oxisols. In: INTERNATIONAL SOIL CLASSIFICATION WORKSHOP, 8., Rio de Janeiro, 1988. Proceedings. Rio de Janeiro, EMBRAPA. 1988. p.71-7.

KÄMPF, N. \& SCHERTMANN, U. Relações entre óxidos de ferro e cor em solos cauliníticos do Rio Grande do Sul. Revista Brasileira Ciência do Solo, Campinas, 7:27-31, 1983.

KÄMPF, N.; COSTA JUNIOR, M.I.; KUNRATH, I.J. Apllication of mossbauer spectroscopy to iron oxides as pedogenic indicators (ACAME-92, Bueno Aires, 1992).

KARATHANASIS, A.D. \& HAJEK, B.F. Evaluation of aluminum smectite stability equilibria in naturally acid soils. Soil Science Society of America Journal, Madison, 48:413-7, 1983.

KENG, J.C.W. \& UEHARAM G. Chemistry, mineralogy and taxonomy of oxisols and ultisols. Soil and Crop Science Society Florida Proceedings, Madison, 33:119-26, 1974.

KING, L.C. Geomorfologia do Brasil Oriental. Revista Brasileira de Geografia, Rio de Janeiro, 18(2):147-265, 1956.

LANDIM, P.M.B.; SOARES, P.C.; FULFARO, V.J. Cenozoic deposits in South; Central Brazil and the engineering geology. In: INTERNATIONAL CONGRESS OF IAEG, 2., São Paulo, 1974. Proceedings. São Paulo, ABGE, 1974.

LEMOS, R.C. \& SANTOS, R.D. Manual de descrição e coleção de solo no campo. 2.ed. Campinas, Sociedade Brasileira de Ciência do Solo, 1984. 45p. 
LEPSCH, I.F.; BUOL, S.W.; DANIELS, R.B. Soil-landscape relationships in an area of the Occidental Plateau of São Paulo, Brazil: I. Geomorphic surface and soil mapping units. Soil Science Society of America Journal, Madison, 41:104-9, 1977a.

LEPSCH, I.F.; BUOL, S.N.; DANIELS, R.B. Soil landscape relationships in the occidental Plateau of São Paulo, Brazil: II soil morphology, genesis and classification. Soil Science of Society American Journal, Madison, 41:109-115, $1977 b$.

LEPSCH, I.F. \& OLIVEIRA, J.B. Explicações sumárias sobre a nova nomenclatura das legendas de mapas pedológicos de São Paulo. Campinas, Instituto Agronômico, 1987. 36p. (IAC. Boletim Técnico, 117).

LEPSCH, I.F. Formações superficiais de origem dos latossolos de São Paulo. In: COLÓQUIO ESTUDO E CARTOGRAFIA DE FORMAÇÕES SUPERFICIAIS E SUAS APLICAÇÕES EM REGIÕES TROPICAIS, 1., São Paulo, 1976. Anais. São Paulo, 1976, p.323-334.

LEPSCH, I.F. Soil landscape relationships in area of the Occidental Plateau of São Paulo State, Brazil. Raleigh, 1975. 163p. (PhD - North Carolina State University).

LEPSCH, I.F. Superficies geomórficas e depósitos superficiais neocenozóicos em Echaporã, SP. Boletim Paulista de Geografia, São Paulo, 53:5-34, 1977.

LEPSCH, I.F. \& BUOL, S.W. Oxisol-landscape relationships in Brazil. In: INTERNATIONAL SOIL CLASSIFICATION WORKSHOP, 8., Rio de Janeiro, 1988. Proceedings. Rio de Janeiro, EMBRAPA/SNLCS, 1988. p.174-89. 
LEPSCH, I.F.; MENK, J.R.F.; OLIVEIRA, J.B. Carbon storage and other properties of soils under agriculture and natural vegetation in São Paulo State, Brazil. Soil Use and Management, 10:34-42, 1994.

LIMA, P.C.; CURI, N.; LEPSCH, I.F. Terminologia de micromofologia do solo. Boletim Informativo da Sociedade Brasileira de Ciência do Solo, Campinas, 10(2):33-43, 1985.

LINSAY, W.L. Chemical equilibria in soil. New York, John Wiley, 1979. 449p.

LUCAS, Y.; BOULET, R.; CHAUVEL, A. Modalites de la formation in situ de stone line en zone equatoriale: exemple d'une coverture ferralitique d'Amazonie an Brésil. Paris, C.R. Academic Science, 1990. t.311. p.713-718. (Serie, 2).

MACEDO, J. \& BRYANT, R.B. Morphology, mineralogy and genesis of a hidrosequence of oxisols in Brazil. Soil Science Society of America Journal, Madison, 51(3):690-8, 1987.

MALO, D.D.; WORCESTER, D.K.; CASSEL, D.K.; MATZDORF, K.D. Soil-landscape relationships in a closed drainage system. Soil Science Society of American Proceedings. Madison. 38:813-17, 1974.

MANZINI, F.F. O cretácio da região de Monte Alto. Rio Claro, 1990. 91p. (Mestrado Instituto de Geociências/UNESP).

MARCELO, J. \& BRYANT, R.B. Morphology, mineralogy and genesis of a hidrosequence of oxisols in Brazil. Soil Science Society of America Journal, Madison, 51(3):690-8, 1987. 
MARQUES JÚNIOR, J. Litocronocrosseqüência de solos da região de Lavras, MG. Lavras, 1988. 78p. (Mestrado - Escola Superior de Agricultura de Lavras).

MARQUES JÚNIOR, J.; CURI, N.; LIMA, J.M. Evolução diferenciada de latossolo vermelho amarelo e latossolo vermelho escuro em função da litologia gnáissica na região de Lavras (MG). Revista Brasileira de Ciência do Solo, Campinas, 16(2):240-53, 1992.

McCARACKEN, R.J.; PEDERSEN, E.J.; AULL, L.E. Soils of the Hayesville, Cecil and Pacolet series in the southern Appchian and Piedmont regions of the United States. Raleigh, North Caroline State University, 1971. 60p. (Bulletin, 157).

MEHRA, O.P. \& JACKSON, M.L. From oxide removal from soils and clays by a dithionite-citrate system buffered with sodium bicarbonate. Clays and Clay Minerals. New York, 7:317-27, 1960.

MIKLÓS, A.A.W. Terra Roxa Estruturada: Organização de origem holocênica. In: XXV CONGRESSO BRASILEIRO DE CIÊNCIA DO SOLO, 25., Viçosa, 1995. Resumos expandidos. Campinas, Sociedade Brasileira de Ciência do Solo, 1995. p.1567-70.

MILNE, G. Some suggested units of classification and mapping particular for East Agrican Soils. Soil Research, Berlin, 4:(3), p.183-8, 1935.

MONIZ, A.C. \& BUOL, S.W. Formation of an oxisol ultisol transition in São Paulo, Brazil: I. Double-water flow model of soil development. Soil Science Society of America Journal. Madison, 46:1228-33, 1982.

MORAES REGO, L.F. de. Notas sobre a geomorfologia de São Paulo e sua gênese. São Paulo, USP/Instituto Astronômico Geofisico, 1932. 
MULLER, J.P. Microestruturation des structichrons rouges ferralitiques, à l'amont des modelés convexes (Centre-Cameroun). Aspects morphologiques. Cahiers ORSTOM. Ser. Ped. 15(3):239-58, 1977.

NATALE, W. \& COUTINHO, E.L.M. Avaliação da eficiência agronômica de frações granulométricas de um calcário dolomítico. Revista Brasileira de Ciência do Solo, Campinas, 18:55-62, 1994.

NETTLETON, W.D.; FLACH, K.W.; BRASHER, B.R. Argillic horizons without clay skins. Soil Science Society of America Proceedings, Madison, 33:121-5, 1969.

NETTLETON, W.D.; ESWARAN, H.; HOLSZEY, C.S.; NELSON, R.E. Micromorphological evidence of clay translocation in poarly dispersible soils. Geoderma, Amsterdam. 40:37-8, 1987.

NORRIS, J.M. Multivariate methods in the study of soils. Soil and Fertilizers, Canberra, 33(4):313-8, 1970.

OLIVEIRA, J.B.; JACOMINE, P.K.T.; CAMARGO, M.N. Classes gerais de solos do Brasil. Jaboticabal, FUNEP, 1992. $201 \mathrm{p}$.

PECK, T.R. \& WELSTED, S.W. Field sampling for soil testing. In: Soil testing and plant analysis. Pan 1. Madison, Soil Science Society America, 1967. p.25-35. (Special Publications, 2)

PEDRO, G.; CHAUVEL, A.; MELFI, A. Recherces sur la constitution des Terra Roxa Estruturada du Brésil. Ann. Agron. 27(3):265-94, 1976. 
PEDRO, G. Géochimie, mineralogie et organisation des sols. Aspects coordonnés des problémes pédogénétiques. Cahiers ORSTOM. Sér. Péd., 23(3):169-86, 1987.

PENTEADO, M.M, \& RANZANI, G. Problemas Geomorfológicos relacionados com a gênese dos solos podzolizados; Marília. São Paulo, USP/Instituto de Geografia, 1973. $23 p$.

PENTEADO, M.M. \& RANZANI, G. Aspectos Geomorfológicos e os solos do município de Jaboticabal. Geographica, Uppsala, 25:42-61, 1971.

PENTEADO, M.M. Geomorfologia do setor Centro Ocidental da Depressão Periférica Paulista. Rio Claro, 1968. 86p. (Doutorado - Instituto de Geografia/USP). (Série Teses e Monografias, 22).

PERES FILHO, A,; DONIZELLI, J.L.; LEPSCH, I.F. Relações solo-paisagem em várzea do rio Mogi-Guaçú (SP). Revista Brasileira Ciência do Solo, Campinas, $4: 181-7,1980$.

PETRI, S. \& FÚlFARO, V.J. Geologia do Brasil. São Paulo, EDUSP. 1983. 631p.

PÖTTER, R.O. \& KÄMPF, N. Argilo-minerais e óxidos de ferro em cambissolos e latossolos sob regime climático térmico údico no Rio Grande do Sul. Revista Brasileira de Ciência do Solo, Campinas, 5(3):153-9, 1981.

QUAGGIO, J.A.; MASCARENHAS, H.A.A.; BATAGLIA, O.C. Resposta da soja à aplicação de doses crescentes de calcário em Latossolo Roxo distrófico de cerrado. II. Efeito residual. Revista Brasileira de Ciência do Solo, Campinas, 6:113-8, 1982. 
QUEIROZ NETO, J·P.; JOURNAUX, A.; PELLERIN, J.; CARVALHO, A. Formações superficiais da região de Marília, SP. São Paulo, USP/Instituto de Geografia, 1977. 39p. (Série Sedimentologia \& Pedologia, B).

QUEIROZ NETO, J.P.; CARVALHO, A.; JOURNAUX, A.; PELLERIN, J. Cronologia da alteração dos solos da região de Marília, SP. São Paulo, USP/Instituto de Geografia, 1973. 55p. (Série Sedimentologia e Pedologia).

QUEIROZ NETO, J.P. \& JOURNAUX, A. Carta geomorfológica do vale do rio do Peixe em Marília, São Paulo, IG/USP, 1978. 11 p.

RAIJ, B. van. Determinação do ponto de carga zero em solos. Bragantia, Campinas, 32(18):337-47, 1973.

RAIJ, B. van. \& PEECH, M. Eletrochemical properties of some oxisols and alfisols of the tropics. Soil Science Society of American Proceedings, Madison, 36(4):587-93, 1972.

RAIJ, B. van \& ZULLO, M.A.T. Métodos de análise de solo. Campinas, Instituto Agronômico, 1977. 16p. (IAC. Circular, 63).

RAIJ, B. van; QUAGGIO, J.A.; CANTARELLA, J.; FERREIRA, M.E.; LOPES, A.S.; BATAGLIA, O.A. Análise química do solo para fins de fertilidade. Campinas, Fundação Cargill, 1987. 170p.

RAYNER, J.H. Classification of soil by numerical methods. Journal of Soil Science, Oxford, 17:79-92, 1966. 
RESENDE, M. et al. Características do solo e da paisagem que influenciam a susceptibilidade à erosão. In: SIMPÓSIO SOBRE MANEJO E CONSERVAÇÃO DO SOLO NO CERRADO, Campinas, 1992. Anais. Campinas, Fundação Cargill, 1992. p.32-67.

ROTA, C.L.; MONIZ, A.C.; LEPSCH, I.F. Mineralogia de uma toposeqüência de solos derivados de rochas ácidas do município de Atibaia, SP. In: CONGRESSO BRASILEIRO DE CIÊNCIA DO SOLO, 15., Campinas, 1976. Anais. p.481-8.

RUHE, R.V. Quaternary Iandscapes in Iowa. Ames, Iowa State University Press, 1969. 255p.

RUHE, R.V. Elements of soil landscape. In: INTERNATIONAL CONGRESS OF SOIL SCIENCE, 7., Madison, USA, 1960. Proceedings. Madison, 1960. p.165-71.

RUHE, R.V. Geomorphic surfaces and the nature of soils. Soil Science. Baltimore, 82:441-5, 1956.

RUHE, R.V.; DANIELS, R.B.; CADY, J.G. Landscape evolution and soil formation in south Western. Ames, USDA, 1967. (Technical Bulletin, 1349).

RUHE, R.V. Geomorphology. Boston, Houghton Miffein, 1975.

SAAD, A.R. Estratigrafia, origem e evolução tectônica da Bacia do Paraná. Rio Claro, UNESP, 1988. (Exame de Qualificação: doutorado).

SANTANA, D.P. Soil formation in toposequence of oxisols from Patos de Minas region, Minas Gerais State, Brazil. West Lafayette, 1984. 129p. (PhD - Purdue University). 
SANTOS, M.C.D.; MERMUT, A.R.; RIBEIRO, M.R. Submicroscopy of clay microagregates in a oxisol from Pernambuco, Brazil. Soil Science Society of America Journal, Madison, 53:1895-1901, 1989.

SCATOLINI, F.M. \& MONIZ, A.C. Influência do material de origem, do lençol freático surgente e da posição topográfica nos solos de uma encosta em Mococa (SP). Revista Brasileira de Ciência do Solo, Campinas, 16(3):379-88, 1992.

SCHWERTMANN, U. \& TAYLOR, R.M. Iron oxides. In: DIXON, J.B. \& WEED, S.B., DIXON, J.B. \& WEED, S.B. Minerals in soil environments. Madison, Soil Society of American, 1977. p.145-80.

SCHWERTMANN, U. \& KÄMPF, N. Properties of goethite and hematite in kaolinitc soils of Sourthern and Central Brazil. Soil Science, Baltimore, 139(4):344-50, 1983.

SCHWERTMANN, U. Differenzierung der eisenoxide des rodens durch extraktion mit ammoniumoxalat-lösung. Zeitschrift für. Pflanzener nährung und Bodenkunde, Wenheim, 105(2):195-202, 1964.

SIMONSON, R.W. Outline of a generalised theory of soil genesis. Proceedings of the Soil Science Society of America, Madison, 23:152-6, 1959.

SIMPSON, G.G. Numerical taxonomy and biological classification. Science, Washingtion, 144:712-93, 1964.

SNEATH, P.H.A. \& SOKAL, R.R. Numerical taxonomy. Nature, London, 193:855-60, 1962. 
SOARES, P.C. \& LANDIM, P.M.B. Depósitos cenozóicos na região Centro-Sul do Brasil. Notícia Geomorfológica, Campinas, 16(31):17-39, 1976.

SOARES, P.C.; LANDIM, P.M.B.; FÚLFARO, V.J.; SOBREIRO NETO, A.F. Ensaio de caracterização estratigráfica do cretáceo no Estado de São Paulo: Grupo Bauru. Revista Brasileira Geociência, São Paulo, 10(3):177-85, 1980.

SOMBROEK, W.G. Soils with Nitic attributes. In: CONGRÉS DE L'ASSOCIATION INTERNATIONALE DE LA SCIENCE DU SOL, 19, Tokyo, 1990.

STOOPS, G. \& JONGERIUS, A. Proposal for a micromorphological classification of soil materials. I. A classification of the related distribution of fine and coarse particles. Geoderma, Amsterdam, 13:189-99, 1975.

STOOPS, G. Micromorphology of the oxic horizon. In: INT. WORK. MEET. SOIL MICROMORPH., 6, London, 1983. Proceedings. Murphy ed., A.B. Rothamsted, Academic Publishers, 1983. v.2, p.419-40.

STOOPS, G. \& BUOL, S.W. Micromorphology of oxisols. In: DOUGLAS, L.A. \& THOMPSON, M.L., ed. Soil micromorphology and soil classification. Madison, SSSA, 1985. p.105-19.

SUGUIO, K. Formação Bauru: calcários e sedimentos detríticos associados. São Paulo, 1973. 2v. (Livre Docência - Instituto de Geografia/USP).

SUGUIO, K.; BARCELOS, J.H.; MATSUI, E. Significados paleoclimáticos e paleoambientais das rochas calcárias da Formação Caatinga $(\mathrm{Ba})$ e do Grupo Bauru (MG/SP). In: CONGRESSO BRASILEIRO DE GEOGRAFIA, 31., Camboriú, 1980. Anais. Camboriú, SBG, 1980, v.1, p.607-17. 
SUGUIO, K. \& COIMBRA, A.M. Estudo sedimentológico das "bandas onduladas" de solos da formação Bauru na área balisada pelas cidades de Oswaldo Cruz, Rancharia e Tupã. Estado de São Paulo. Boletim do Instituo Geológico - USP, São Paulo, 7:27-38, 1976.

SUGUIO, K. Fatores paleoambientais e paleoclimáticos e subdivisão estratigráfica do Grupo Bauru. In: MESA REDONDA - "A FORMAÇÃO BAURU NO ESTADO DE SÃO PAULO E REGIÕES ADJACENTES", São Paulo, 1980. Coletânea de trabalhos e debates. São Paulo, Sociedade Brasileira de Geologia/Núcleo de São Paulo, 1980. p.15-30.

TAN, K.H. Principles of soil chemistry. New York, Marcel Decker, 1982. 267p.

TRICART, J. As relações entre a morfogênese e a pedogênese. Campinas. Notícia Geomorfológica, Campinas, 8(15):5-18, 1968.

UPCHURCH, D.R. \& EDMONDS, W.J. Statistical procedures for specific objectives. In: MAUSBACJ, M.J. \& WILDING, L.P. Spatial variabilities of soils and landforms. Madison, Soil Science Society América, 1993. p.49-71.

VAN DEN BROEK, M.; VAN AMSTEL, A.; VERBAKEL, A.; PEDROLI, B. Variability of soil properties in a landscape ecological survey at the Tuscan Apennines, Italy. Catena. 8:155-70, 1981.

VETTORI, L. Métodos de análise de solo. Rio de Janeiro, EMBRAPA/SNLCS, 1969, 34p. (Boletim Técnico, 7). 
VIDAL TORRADO, P. \& LEPSCH, I.F. Morfogênese dos solos de uma topossequência com transição B latossólico x B textural sobre migmatitos em Mococa (SP). Revista Brasileira de Ciência do Solo. Campinas, 17(1):109-19, 1993.

VIDAL-TORRADO, P. Pedogênese e Morfogênese no distrito de Tupi (Piracicaba, SP). Piracicaba, 1994. 212p. (Doutorado - Escola Superior de Agricultura "Luiz de Queiroz"/USP).

WANG, C. Variability of soil properties in relation to size of map unit delineation. Canadian Journal of Soil Science. Ottawa. 62:657-62, 1982.

WALKER, P.H.; HALL, G.F.; PROTZ, R. Relation between land form parameters and soil properties. Soil Science Society of American Journal. Proceedings. 32(1):1015, 1968.

WEBSTER, R. Mathematical Geology. New York. Automatic soil-boundary location from transect data. Math. Geol. 5:27-37, 1973.

WEBSTER, R. \& CUANALO DE Lac. Soil transect correlograms of north oxfordshire and their interpretation. Journal of Soil Science, Oxford, 26(2):176-94, 1975.

WEBSTER, R. \& WONG, I.F.T. A numerical procedure for testing soil boundaries interpreted from air photographs. Photogrammetria, 24:59-72, 1969.

WEBSTER, R. Optimally partitioning soil transects. Journal of Soil Science, Oxford, 29:388-402, 1978.

WEBSTER, R. \& BECKETT, P.H.T. Quality and usefulness of soil maps. Nature, London. 219:680-2, 1968. 
WILDING, L.P. \& DREES, L.R. Spatial variability and pedology. In: PEDOGENESIS and soil taxonomy. I concepts and interactions. New York, Elsevier, 1983. p.83-116.

WOOD, A. The development of hillside slopes. Geology Association Proceedings, 53:128-38, 1942.

WRIGHT, R.L. On the analysis of soil variability with an example from Spain. Geoderma. 22:297-313, 1979.

YOUNG, A. Slopes. London, Songman, 1972. 288p. 
A P E N D I C E 1

ESTEREOGRAMA DA ÁREA EM ESTUDO 


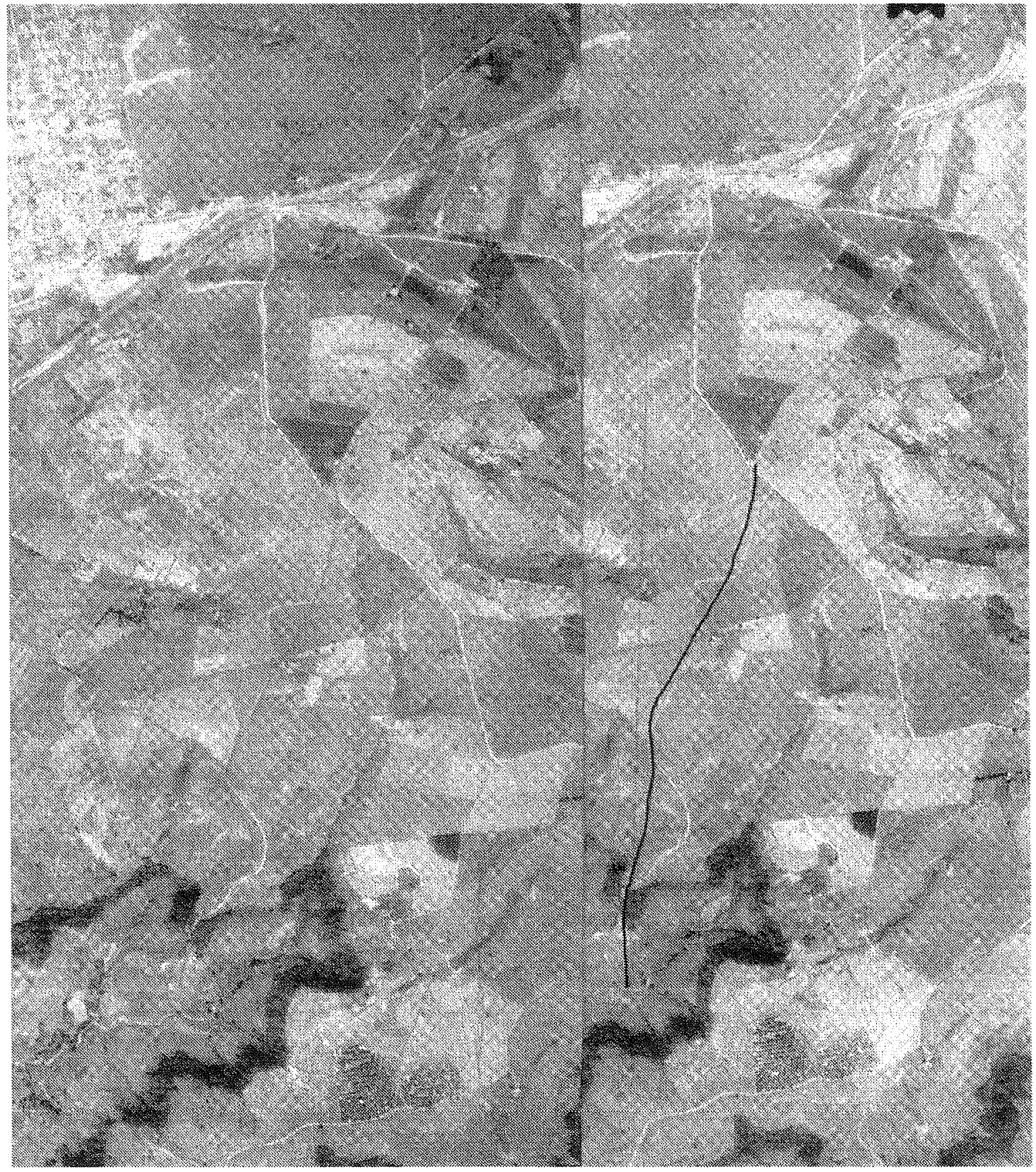

Transeção na área estudada 
A P E NDICE 2

DESCRIÇÃO DOS PERFIS DOS SOLOS ESTUDADOS 


\section{PERFIL $\mathrm{N}^{\circ}-1$}

CLASSIFICAÇÃO - Latossolo Vermelho-Escuro Distrófico A moderado textura média relevo plano.

UNIDADE DE MAPEAMENTO - LV

LOCALIZAÇÃO, MUNICÍPIO, ESTADO E COORDENADAS - Em Monte Alto (SP) noroeste da sede da cidade a 100 metros da "Torre de Record".

SITUAÇÃO, DECLIVE E COBERTURA VEGETAL SOBRE O PERFIL - Trincheira situada no topo da Superficie I, sob cultivo de cana-de-açúcar.

ALTITUDE - 763 metros.

MATERIAL ORIGINÁRIO - Depósito superficial arenoso derivado do arenito da formação Marilia.

PEDREGOSIDADE - Ausente.

ROCHOSIDADE - Ausente.

RELEVO LOCAL - Plano.

RELEVO REGIONAL - Suave ondulado.

EROSÃO - Laminar moderada.

DRENAGEM - Bem drenado.

VEGETAÇÃO PRIMÁRIA - Floresta tropical subcaducifólia.

USO ATUAL - Cana-de-açúcar.

CLIMA - Cwa da classificação de Köppen

DESCRITO E COLETADO POR - J. Marques Júnior e I.F. Lepsch. 
Perfil 1. Latossolo Vermelho-Escuro (LV)

$A p_{1}$ - 0-23 cm; bruno-avermelhado-escuro (5YR 3/3, úmida); franco arenoso; moderada a fraca pequena a muito pequena blocos subangulares; macio, friável, não plástico, não pegajoso, transição plana e gradual.

$A B$ - 23-52 cm; bruno-avermelhado (3,5YR 4/4, úmida); franco-argilo-arenoso; moderada a fraca pequena blocos subangulares; ligeiramente duro, muito friável, não plástico, não pegajoso; transição plana e gradual.

BA - 52-60 cm; bruno-avermelhado (3,5YR 4/3, úmida); franco-argilo-arenoso; fraca média a grande blocos subangulares que se desfazem em grânulos; ligeiramente duro e macio, friável, ligeiramente plástico e não pegajoso; transição plana e gradual.

$\mathrm{Bw}_{1}$ - 80-126 cm; vermelho-amarelado (3,5YR 4/6, úmida); franco-argilo-arenoso; fraca pequena granular aspecto maciço poroso in situ; macio, muito friável, ligeiramente plástico e não pegajoso; transição plana e gradual.

$\mathrm{Bw}_{2}$ - 128-180 cm; vermelho-amarelado (3,5YR 4/6 úmida); franco-argilo-arenoso; fraca pequena granular aspecto maciço poroso in situ; macio, muito friável, ligeiramente plástico e não pegajoso.

Raízes abundantes no $\mathrm{Ap}_{1}$ e $\mathrm{AB}$, comuns no $\mathrm{BA}$ e $\mathrm{Bw}_{1}$ e poucas no $\mathrm{Bw}_{2}$. 
LATOSSOLO VERMELHO-AMARELO (LV)

\begin{tabular}{|c|c|c|c|c|c|c|c|c|c|c|c|}
\hline \multicolumn{2}{|c|}{ HORIZONTE } & \multicolumn{4}{|c|}{ CONPOSIÇÃO GRANULONÉTRICA } & \multirow{2}{*}{$\begin{array}{l}\text { ARGILA } \\
\text { OISPERSA } \\
\text { AGOA } \\
\quad(x)\end{array}$} & \multirow{2}{*}{$\begin{array}{c}\text { GRAU DE } \\
\text { FLOCULACYO } \\
\text { (趹 }\end{array}$} & \multirow[t]{2}{*}{$\frac{\text { SILTE }}{\text { ARGILA }}$} & \multicolumn{2}{|c|}{$\begin{array}{c}\text { DENSIDADE } \\
\left(\mathrm{g} / \mathrm{c}^{3}\right) \\
\end{array}$} & \multirow{2}{*}{ 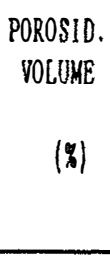 } \\
\hline SÍMBOLO & $\begin{array}{l}\text { PROF. } \\
\text { (Ca) }\end{array}$ & $\begin{array}{c}\text { AREIA } \\
\text { GROSSA } \\
(\mathbf{D}) \\
\end{array}$ & $\begin{array}{l}\text { AREIA } \\
\text { EIHA } \\
(\not) \\
\end{array}$ & $\begin{array}{c}\text { SILTE } \\
(\dddot{a}) \\
\end{array}$ & $\begin{array}{l}\text { ARGILA } \\
(x) \\
\end{array}$ & & & & APARENTE & REAL & \\
\hline Ap & $0-23$ & 38 & 39 & 4 & 19 & 18,3 & 3,1 & 0,21 & 1,47 & 2,53 & 43,15 \\
\hline$A B$ & $23-52$ & 32 & 35 & 4 & 29 & 23,3 & 19,6 & 0,14 & 1,50 & 2,50 & 42,87 \\
\hline$B A$ & $52-80$ & 28 & 37 & j & 32 & $24,0$. & 25,0 & 0,09 & 1,50 & 2,53 & 50,60 \\
\hline$B \times 1$ & $80-128$ & 32 & 35 & 2 & 31 & 27,2 & 12,2 & 0,06 & 1,30 & 2,53 & 42,42 \\
\hline B 12 & $128-180$ & 28 & 39 & 6 & 27 & 12,5 & 53,7 & 0,22 & 1,35 & 2,49 & 48,32 \\
\hline Tradagen & $180-220$ & 30 & 38 & 3 & 29 & 25,1 & 13,4 & 0,10 & $\ldots$ & 2,52 & $\ldots$ \\
\hline Tradager & $220-260$ & 29 & 38 & 5 & 28 & 25,8 & 7,8 & 0,18 & $\ldots$ & 2,57 & $\ldots$ \\
\hline Tradagen & $260-300$ & 28 & 36 & 3 & 33 & 6,5 & 80,3 & 0,09 & $\ldots$ & 2,47 & $\ldots$ \\
\hline
\end{tabular}

\begin{tabular}{|c|c|c|c|c|c|c|c|c|c|c|c|c|c|}
\hline \multicolumn{3}{|c|}{$\mathrm{pH}(1: 2,5)$} & \multirow{2}{*}{$\begin{array}{c}\text { DELTA } \\
\mathrm{pH}\end{array}$} & \multicolumn{3}{|c|}{ BASES TROCAVEIS } & \multirow{2}{*}{$\begin{array}{l}\text { SOMA } \\
\text { BASES }\end{array}$} & \multirow[t]{2}{*}{$\mathrm{Al}^{3+}$} & \multirow[t]{2}{*}{$\mathrm{H}+\mathrm{Al}$} & \multirow[t]{2}{*}{$\mathrm{T}$} & \multirow{2}{*}{$\begin{array}{c}\text { Saturação } \\
\text { por bases } \\
(V) \mid\end{array}$} & \multirow{2}{*}{$\begin{array}{c}\text { Saturação } \\
\text { por Al } \\
(\text { ol })\end{array}$} & \multirow{2}{*}{$\begin{array}{c}p \\
\text { (resina) } \\
\mu g / \mathrm{cm}^{3}\end{array}$} \\
\hline $\mathrm{CaCl}_{2}$ & SGUA & $\mathrm{KCl}$ & & $\mathrm{Ca}^{3+}$ & $\mathrm{Mg}^{++}$ & $k^{+}$ & & & & & & & \\
\hline & & & & & & & & & & & & & \\
\hline 4,7 & 5,9 & 4,7 & $-1,2$ & 1,6 & 0,7 & 0,19 & 2,49 & 0 & 3,4 & 5,89 & 42 & 0 & 1 \\
\hline 4,1 & 4,9 & 4,2 & $-0,7$ & 1,2 & 0,3 & 0,01 & 1,51 & 0,1 & 5,8 & 7,31 & 21 & 31,7 & f \\
\hline 4,4 & 5,0 & 4,4 & $-0,6$ & 1,7 & 0,3 & 0,01 & 2,01 & 0,2 & 3,4 & 5,41 & 39 & 31,7 & 1 \\
\hline 4,4 & 5,3 & 4,5 & $-0,8$ & 1,4 & 0,3 & 0,01 & 1,11 & 0,2 & 2,8 & 4,51 & 38 & 10,5 & $i$ \\
\hline 4,4 & 5,0 & 4,4 & $-0,6$ & 1,1 & 0,2 & 0,01 & 1,31 & 0,2 & 3,1 & 4,41 & 30 & 13,2 & 1 \\
\hline 4,7 & 5,4 & 4,9 & $-0,5$ & 1,4 & 0,3 & 0,01 & 1,71 & 0 & 2,5 & 4,21 & 41 & 0 & 1 \\
\hline 4,6 & 5,2 & 5,0 & $-0,2$ & 1,3 & 0,3 & 0,01 & 1,61 & 0 & 2,5 & 4,11 & 39 & 0 & 1 \\
\hline 4,5 & 5,4 & 5,0 & $-0,4$ & 1,1 & 0,2 & 0,01 & 1,31 & 0 & 2,5 & 3,81 & 34 & 0 & 2 \\
\hline
\end{tabular}

\begin{tabular}{|c|c|c|c|c|c|c|c|}
\hline \multicolumn{3}{|c|}{$\begin{array}{c}\text { ATAQUE SULFúRICO } \\
\left(\mathrm{H}_{2} \mathrm{SO}_{4} l: 1\right)\end{array}$} & \multirow[t]{2}{*}{$\operatorname{SiO}_{(\mathrm{Ki})} \mathrm{All}_{3}$} & \multirow[t]{2}{*}{$\begin{array}{c}\operatorname{sio} 2 R_{2} A_{3} \\
(K r)\end{array}$} & \multirow[t]{2}{*}{$\mathrm{Al}_{2} \mathrm{O}_{3} \mathrm{Fe}_{2} \mathrm{O}_{3}$} & \multirow{2}{*}{$\begin{array}{l}\text { CARBONO } \\
\text { ORGANICO } \\
\left(\begin{array}{l}\text { (y) }\end{array}\right.\end{array}$} & \multirow{2}{*}{$\begin{array}{l}\text { Ho } \\
(\text { g) }\end{array}$} \\
\hline $\mathrm{SiO}_{2}$ & $\mathrm{Al}_{2} \mathrm{O}_{3}$ & $\mathrm{Fe}_{2} \mathrm{O}_{3}$ & & & & & \\
\hline 6,9 & 10,5 & 1,5 & 1,1 & 1,0 & 10,9 & 1,10 & 1,9 \\
\hline 12,5 & 12,5 & 1,2 & 1,7 & 1,7 & 16,3 & 0,69 & 1,2 \\
\hline 11,1 & 14,5 & 1,0 & 1,3 & 1,2 & 22,8 & 0,46 & 0,8 \\
\hline 11,2 & 13,0 & 2,5 & 1,5 & 1,3 & 8,2 & 0,40 & 0,7 \\
\hline 11,7 & 13,5 & 2,3 & 1,5 & 1,3 & 9,1 & 0,30 & 0,6 \\
\hline 13,2 & 13,0 & 3,0 & 1,7 & 1,5 & 6,7 & 0,23 & 0,4 \\
\hline 7,1 & 13,5 & 2,4 & 0,9 & 0,8 & 8,8 & 0,17 & 0,3 \\
\hline 11,5 & 14,0 & 0,8 & 1,4 & 1,3 & 27,5 & 0,17 & 0,3 \\
\hline
\end{tabular}




\section{PERFIL N $N^{\circ} 2$}

CLASSIFICAÇÃO - Latossolo Vermelho-Amarelo podzólico Distrófico A moderado textura média relevo suave ondulado.

UNIDADE DE MAPEAMENTO - LVp

LOCALIZAÇÃO, MUNICÍPIO, ESTADO E COORDENADAS - Em Monte Alto (SP), a 500 metros da "Torre da Record", no sentido da Fazenda Paredão.

SITUAÇÃO, DECLIVE E COBERTURA SOBRE O PERFIL - Trincheira situada no ombro superior da Superfície II. Cultivo de manga.

ALTITUDE - 735 metros.

MATERIAL ORIGINÁRIO - Depósito superficial arenoso derivado do arenito da formação Marília.

PEDREGOSIDADE - Ausente.

ROCHOSIDADE - Ausente.

RELEVO LOCAL - Suave ondulado.

RELEVO REGIONAL - Suave ondulado.

EROSÃO - Laminar moderada.

VEGETAÇÃO PRIMÁRIA - Floresta tropical subcaducifólia.

USO ATUAL - Cultura de manga.

CLIMA - Cwa da classificação de Köppen.

DESCRITO E COLETADO POR - J. Marques Júnior e I.F. Lepsch. 
Perfil 2. Latossolo Vermelho-Amarelo Podzólico (LVp)

Ap - 0-24 cm; bruno-avermelhado-escuro (5YR 3/3, úmida); franco-argilo-arenoso; moderada a fraca pequena a média blocos subangulares; macio a ligeiramente duro, firme, ligeiramente plástico; transição plana e clara.

BA - 24-41 cm; bruno-avermelhado-escuro (5YR 3/4, úmida); franco-argilo-arenoso; moderada a fraca média blocos subangulares; ligeiramente duro, friável, ligeiramente plástico e ligeiramente pegajoso; transição plana e gradual.

$\mathrm{Bw}_{1}$ - 41-80 cm; bruno-avermelhado (5YR 4/4, úmida); franco-argilo-arenoso; moderada a fraca média e pequena blocos subangulares; macio, friável a firme, ligeiramente plástico e ligeiramente pegajoso; transição plana e gradual.

$\mathrm{Bw}_{2}$ - 80-120 cm; vermelho-amarelado (5YR 4/6, úmida); franco-argilo-arenoso; fraca a moderada pequena a muito pequena blocos que se desfazem em grânulos; macio, friável, ligeiramente plástico e ligeiramente pegajoso; transição plana e gradual.

$\mathrm{Bw}_{3}$ - 120-169; vermelho-amarelado (5YR 4/6, úmida); franco-argilo-arenoso; fraca a moderada pequena blocos que se desfazem em grânulos; macio, friável, ligeiramente plástico, ligeiramente pegajoso.

Raízes abundantes no $\mathrm{Ap}$ e $\mathrm{BA}$, muitas no $\mathrm{Bw}_{1}$, comuns no $\mathrm{Bw}_{2}$ e ausentes no $\mathrm{Bw}_{3}$. 
LATOSSOLO VERMELHO-AYARELO POOZÓLICO

\begin{tabular}{|c|c|c|c|c|c|c|c|c|c|c|c|}
\hline \multicolumn{2}{|c|}{ HORIZORTE } & \multicolumn{4}{|c|}{ COMPOSIÇÃO GRANULOMETRICA } & \multirow{2}{*}{$\begin{array}{l}\text { ARGILA } \\
\text { DISPERSA } \\
\text { AGUA } \\
\quad(X)\end{array}$} & \multirow{2}{*}{$\begin{array}{c}\text { GRAU OE } \\
\text { FLOCULAÇÃ̃O } \\
(y)\end{array}$} & \multirow[t]{2}{*}{$\frac{\text { SILTE }}{\text { ARGILA }}$} & \multicolumn{2}{|c|}{$\begin{array}{c}\text { DEMSIDADE } \\
\left.(\mathrm{g} / \mathrm{c})^{3}\right)\end{array}$} & \multirow{2}{*}{$\begin{array}{r}\text { POROSID. } \\
\text { VOLUNE } \\
(x)\end{array}$} \\
\hline SIMBOLO & $\begin{array}{l}\text { PROF. } \\
\text { (CD) }\end{array}$ & $\begin{array}{c}\text { AREIA } \\
\text { GROSSA } \\
(x)\end{array}$ & $\begin{array}{l}\text { AREIA } \\
\text { FINA } \\
(x)\end{array}$ & $\begin{array}{c}\text { SILTE } \\
(x)\end{array}$ & 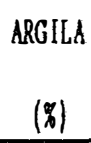 & & & & APARENTE & REAL & \\
\hline sp & $0-24$ & 44 & 33 & 2 & 21 & 17,1 & 18,6 & 0,10 & 1,69 & 2,53 & 36,56 \\
\hline$B A$ & $24-41$ & 36 & 30 & 3 & 31 & 27,8 & 10,3 & 0,10 & 1,48 & 2,53 & 45,42 \\
\hline Bul & $41-80$ & $3\}$ & 30 & 2 & 35 & 30,7 & 12,3 & 0,06 & 1,28 & 2,53 & 54,02 \\
\hline $8 \times 2$ & $80-120$ & 33 & 32 & $\jmath$ & 32 & 27,2 & 15,0 & 0,09 & 1,34 & 2,54 & 49,68 \\
\hline$B \times 3$ & $120-169$ & 32 & 34 & 2 & 32 & 0,1 & 99,6 & 0,06 & 1,37 & 2,55 & 47,94 \\
\hline Tradage & $169-209$ & 29 & 37 & S & 29 & 0,4 & 98,6 & 0,17 & $\ldots$ & 2,47 & $\ldots$ \\
\hline Tradage & $209-249$ & 30 & 36 & 3 & 31 & 0,5 & 98,3 & 0,10 & $\ldots$ & 2,52 & $\ldots$ \\
\hline Tradage & $249-289$ & 29 & 34 & $f$ & 32 & 0,2 & 99,4 & 0,16 & $\ldots$ & 2,49 & $\ldots$ \\
\hline
\end{tabular}

\begin{tabular}{|c|c|c|c|c|c|c|c|c|c|c|c|c|c|}
\hline \multicolumn{3}{|c|}{$\mathrm{pH}(1: 2,5)$} & \multirow{2}{*}{$\begin{array}{c}\text { DELTA } \\
\mathrm{pH}\end{array}$} & \multicolumn{3}{|c|}{ BASES TROCAVEIS } & \multirow{2}{*}{$\begin{array}{l}\text { SOMA } \\
\text { BASES }\end{array}$} & \multirow[t]{2}{*}{$\mathrm{Al}^{3+}$} & \multirow[t]{2}{*}{$\mathrm{H}+\mathrm{Al}$} & \multirow[t]{2}{*}{$\mathrm{T}$} & \multirow{2}{*}{$\begin{array}{c}\text { Saturação } \\
\text { por bases } \\
(v x)\end{array}$} & \multirow{2}{*}{$\begin{array}{c}\text { Saturação } \\
\text { por Al } \\
\text { (n) }\end{array}$} & \multirow{2}{*}{$\begin{array}{c}\mathrm{P} \\
\text { (resina) } \\
\mu g / \mathrm{ct}^{3} \\
\end{array}$} \\
\hline $\mathrm{CaCl}_{2}$ & SGOA & $\mathrm{KCl}$ & & $\mathrm{Ca}^{3+}$ & $\mathrm{Hg}^{++}$ & $K^{+}$ & & & & & & & \\
\hline & & & & $-\cdots$ & --4 & - & 1 & $g$ & 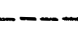 & & & & \\
\hline 4,7 & 5,7 & 4,6 & $-1,1$ & 2,0 & 0,5 & 0,26 & 2,76 & 0,2 & 3,8 & 6,56 & 42 & 7 & 105 \\
\hline 4,3 & 5,1 & 4,4 & $-0,7$ & 1,1 & 0,3 & 0,10 & 1,50 & 0,5 & 3,8 & 5,30 & 28 & 25 & 6 \\
\hline 4,4 & 5,0 & 4,4 & $-0,6$ & 1,2 & 0,3 & 0,01 & 1,51 & 0,5 & 3,4 & 4,91 & 31 & 25 & 1 \\
\hline 4,3 & 5,0 & 4,5 & $-0,5$ & 1,0 & 0,1 & 0,01 & 1,11 & 0,4 & 3,1 & 4,21 & 26 & 26 & 1 \\
\hline 4,4 & 5,1 & 4,5 & $-0,6$ & 0,8 & 0,2 & 0,02 & 1,02 & 0,4 & 2,5 & 3,52 & 29 & 28 & 1 \\
\hline 5,0 & 5,4 & 5,3 & $-0,1$ & 1,0 & 0,3 & 0,07 & 1,37 & 0,0 & 1,6 & 2,97 & 49 & 0 & 1 \\
\hline 4,5 & 6,9 & 5,3 & $-0,6$ & 0,5 & 0,2 & 0,08 & 0,78 & 0 & 1,8 & 2,58 & 30 & 0 & 1 \\
\hline 4,3 & 5,2 & 5,1 & $-0,1$ & 0,4 & 0,1 & 0,01 & 0,51 & 0 & 2,0 & 2,51 & 20 & 0 & 2 \\
\hline
\end{tabular}

\begin{tabular}{|c|c|c|c|c|c|c|c|}
\hline \multicolumn{3}{|c|}{$\begin{array}{l}\text { ATAQUE SULFÚRICO } \\
\left(\mathrm{H}_{2} \mathrm{SO}_{4} 1: 1\right)\end{array}$} & \multirow[t]{2}{*}{$\begin{array}{l}\operatorname{sio}_{(X i)} \mathrm{All}_{2} \mathrm{O}_{3} \\
\end{array}$} & \multirow[t]{2}{*}{$\begin{array}{l}\operatorname{sio}_{2} R_{2} R_{3} \\
(\mathrm{Kr})\end{array}$} & \multirow[t]{2}{*}{$\mathrm{Al}_{2} \mathrm{O}_{3} \mathrm{Fe}_{2} \mathrm{O}_{3}$} & \multirow{2}{*}{$\begin{array}{c}\text { CARBONO } \\
\text { ORGÂNICO } \\
\left(\begin{array}{l}\text { D } \\
\mid\end{array}\right)\end{array}$} & \multirow{2}{*}{ (n) } \\
\hline $\mathrm{SiO}_{2}$ & $\mathrm{Al}_{2} \mathrm{O}_{3}$ & $\mathrm{Fe}_{2} \mathrm{O}_{3}$ & & & & & \\
\hline 12,4 & 8,0 & 1,5 & 2,3 & 3,4 & 8,4 & 0,99 & 1,1 \\
\hline 10,5 & 12,5 & 0,9 & 1,4 & 1,3 & 21,8 & 0,64 & 1,1 \\
\hline 15,1 & 15,0 & 1,3 & 1,1 & 1,6 & 18,1 & 0,81 & $0, ?$ \\
\hline 14,2 & 14,0 & 2,8 & 1,7 & 1,5 & 7,8 & 0,35 & 0,6 \\
\hline 13,9 & 13,5 & 2,1 & 1,7 & 1,5 & 10,9 & 0,29 & 0,5 \\
\hline 13,8 & 13,0 & 3,6 & 1,8 & 1,5 & 5,7 & 0,17 & 0,3 \\
\hline 14,3 & 14,0 & 2,3 & 1,7 & 1,5 & 9,5 & 0,17 & 0,3 \\
\hline 16,2 & 15,0 & 2,7 & 1,8 & 1,6 & 8,7 & 0,17 & 0,3 \\
\hline
\end{tabular}




\section{PERFIL $\mathrm{N}^{\circ}-3$}

CLASSIFICAÇÃO - Podzólico Vermelho-Amarelo Eutrófico Tb abrupto A moderado textura arenosa/média relevo suave ondulado.

UNIDADE DE MAPEAMENTO -

LOCALIZAÇÃO, MUNICÍPIO, ESTADO E COORDENADAS - Em Monte Alto (SP), a 1000 metros da "Torre da Record", no sentido da Fazenda Paredão.

SITUAÇÃO, DECLIVE E COBERTURA VEGETAL SOBRE O PERFIL - Trincheira situada na meia encosta da Superficie II, cultivo de citrus.

ALTITUDE - 728 metros.

LITOLOGIA - Arenito.

FORMAÇÃO GEOLÓGICA - Formação Marília (Grupo Bauru).

CRONOLOGIA - Cretáceo.

MATERIAL ORIGINÁRIO - Depósito superficial arenoso derivado do arenito da formação Marília.

PEDREGOSIDADE - Ausente.

ROCHOSIDADE - Ausente.

RELEVO LOCAL - Suave ondulado.

RELEVO REGIONAL - Suave ondulado.

EROSÃO - Laminar moderada.

DRENAGEM - Bem drenado.

VEGETAÇÃO PRIMÁRIA - Floresta tropical subcaducifólia.

USO ATUAL - Cultura de citrus.

CLIMA - Cwa da classificação de Köppen.

DESCRITO E COLETADO POR - J. Marques Júnior e I.F. Lepsch. 
Perfil 3. Podzólico Vermelho-Amarelo (PV-2)

$A_{1}$ - 0-15 cm; bruno-avermelhado-escuro (5YR 3/3 úmido); areia; fraca média e pequena granular; ligeiramente duro, friável, não plástico e não pegajoso; transição plana e clara.

$\mathrm{A}_{2}$ - 15-30 cm; bruno-avermelhado (5YR 4/3, úmido); areia; moderada pequena e média granular; ligeiramente duro, friável, não plástico e não pegajoso; transição plana e clara.

E - 30-61 cm; bruno-avermelhado-escuro (5YR 3/4, úmido); areia franca; fraca média blocos subangulares e pequena granular; ligeiramente duro, friável, ligeiramente plástico e não pegajoso; transição plana e abrupta.

$\mathrm{Bt}_{1}$ - 61-100 cm; vermelho-amarelado (5YR 4/6, úmido); franco-argilo-arenoso; moderada média blocos subangulares; cerosidade comum e moderada; duro, muito friável, plástico e ligeiramente pegajoso; transição plana e gradual.

$\mathrm{Bt}_{2}$ - 100-165 cm; vermelho-amarelado (5YR 4/6, úmido); franco-argilo-arenoso; moderada média e pequena blocos subangulares; cerosidade comum e forte; duro, friável, plástico e ligeiramente pegajoso.

Raízes abundantes no $A_{1}$ e $A_{2}$, muitas no $E$, comuns no $B_{1}$ e poucas no $B_{2}$.

Observações: Presença de fendas de atividades biológica na transição dos horizontes $\mathrm{E} e$ $B_{1}$. 
POOZÓLICO VERMELHO-AMARELO (LIMÃO)

\begin{tabular}{|c|c|c|c|c|c|c|c|c|c|c|c|}
\hline \multicolumn{2}{|c|}{ HORI ZONTE } & \multicolumn{4}{|c|}{ COMPOSIÇTOO GRANULONÉTRICA } & \multirow{2}{*}{$\begin{array}{l}\text { ARGILA } \\
\text { OISPERSA } \\
\text { AGUA } \\
\quad(\$)\end{array}$} & \multirow{2}{*}{$\begin{array}{c}\text { GRAU DE } \\
\text { ELOCULAÇÃO } \\
\mid(x)\end{array}$} & \multirow[t]{2}{*}{$\frac{\text { SILTE }}{\text { ARGILA }}$} & \multicolumn{2}{|c|}{$\begin{array}{c}\text { DENSIDADE } \\
\left(\mathrm{g} / \mathrm{cm}^{3}\right)\end{array}$} & \multirow{2}{*}{ 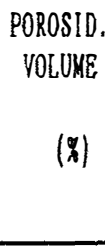 } \\
\hline SINBOLO & $\begin{array}{l}\text { PROR. } \\
\text { (C) }\end{array}$ & $\begin{array}{c}\text { AREIA } \\
\text { GROSSA } \\
(\mathbf{X})\end{array}$ & $\begin{array}{l}\text { AREIA } \\
\text { FINA } \\
(x)\end{array}$ & $\begin{array}{l}\text { SILTE } \\
(\not) \\
\end{array}$ & $\begin{array}{l}\text { ARGILA } \\
(x)\end{array}$ & & & & APARENTE & REAL & \\
\hline Al & $0-15$ & 63 & 26 & 2 & 8 & 6,9 & 23,3 & 0,25 & 1,54 & 2,52 & 43,00 \\
\hline$A 2$ & $15-30$ & 70 & 19 & 2 & 9 & 7,1 & 21,1 & 0,22 & 1,60 & 2,59 & 42,67 \\
\hline$A B$ & $30-61$ & 63 & 20 & 3 & 14 & 12,2 & 12,8 & 0,21 & 1,56 & 2,60 & 37,88 \\
\hline Bt 1 & $61-100$ & 49 & 18 & 2 & 31 & 29,1 & 6,1 & 0,06 & 1,60 & 2,55 & $\$ 1,20$ \\
\hline Bt2 & $100-165$ & 50 & 15 & 1 & 34 & 27,9 & 17,9 & 0,03 & 1,52 & 2,54 & 40,17 \\
\hline Tradagen & $165-205$ & 54 & 20 & 2 & 24 & 1,2 & 95,0 & 0,08 & .. & 2,55 & $\ldots$ \\
\hline Tradage & $205-245$ & 60 & 16 & 2 & 22 & 0,4 & 98,0 & 0,09 & $\ldots$ & 2,54 & $\ldots$ \\
\hline Tradage & $245-285$ & 55 & 19 & 1 & 25 & 1,4 & 94,4 & 0,04 & $\ldots$ & 2,58 & $\ldots$ \\
\hline
\end{tabular}

\begin{tabular}{|c|c|c|c|c|c|c|c|c|c|c|c|c|c|}
\hline \multicolumn{3}{|c|}{ ph $(1: 2,5)$} & \multirow{2}{*}{$\begin{array}{c}\text { DELTA } \\
\text { PH }\end{array}$} & \multicolumn{3}{|c|}{ BASES TROCAVEIS } & \multirow{2}{*}{$\begin{array}{l}\text { SOMA } \\
\text { BASES }\end{array}$} & \multirow[t]{2}{*}{$\mathrm{Al}^{3+}$} & \multirow[t]{2}{*}{$\mathrm{H}+\mathrm{Al}$} & \multirow[t]{2}{*}{$T$} & \multirow{2}{*}{$\begin{array}{c}\text { Saturação } \\
\text { por bases } \\
\text { (U\$) }\end{array}$} & \multirow{2}{*}{$\begin{array}{c}\text { Saturação } \\
\text { por Al } \\
\left(\begin{array}{l}\text { (o) } \\
\text { ( ) }\end{array}\right.\end{array}$} & \multirow{2}{*}{$\begin{array}{c}P \\
\text { (resina) } \\
\mu \mathrm{G} / \mathrm{Cm}^{3}\end{array}$} \\
\hline $\mathrm{CaCl}_{2}$ & SGUA & $\mathrm{KCl}$ & & $\mathrm{Ca}^{3+}$ & $\mathrm{Mg}^{++}$ & $K^{+}$ & & & & & & & \\
\hline & & & & 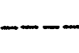 & 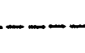 & IIt & 110 & $g-$ & 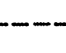 & & & & \\
\hline 5,4 & 6,4 & 6,3 & $-0,1$ & 1,7 & 0,6 & 0,01 & 2,31 & 0 & 1,6 & 3,91 & 59 & 0 & 7 \\
\hline 4,5 & 5,9 & 5,1 & $-0,8$ & 1,0 & 0,3 & 0,01 & 1,31 & 0,2 & 2,5 & 3,81 & 34 & 15 & 4 \\
\hline 4,5 & 5,7 & 4,6 & $-1,1$ & 1,1 & 0,2 & 0,01 & 1,31 & 0,3 & 2,5 & 3,81 & 34 & 23 & 1 \\
\hline 4,7 & 5,5 & 4,9 & $-0,6$ & 1,6 & 0,5 & 0,07 & 2,17 & 0,2 & 2,8 & 4,97 & 44 & 9 & 1 \\
\hline 5,0 & 5,8 & 5,6 & $-0,2$ & 1,9 & 0,3 & 0,01 & 2,21 & 0 & 1,8 & 4,01 & 55 & 0 & 1 \\
\hline 5,4 & 6,1 & 6,0 & $-0,1$ & 1,8 & 0,3 & 0,03 & 2,13 & 0 & 1,3 & 3,43 & 62 & 0 & 1 \\
\hline 5,3 & 6,0 & 6,1 & 0,1 & 1,4 & 0,5 & 0,01 & 1,91 & 0 & 1,3 & 3,21 & 60 & 0 & 1 \\
\hline 5,3 & 6,1 & 6,2 & 0,1 & 1,3 & 0,8 & 0,01 & 2,11 & 0 & 1,3 & 3,41 & 62 & 0 & 1 \\
\hline
\end{tabular}

\begin{tabular}{|c|c|c|c|c|c|c|c|}
\hline \multicolumn{3}{|c|}{$\begin{array}{l}\text { ATAQUE SULFÚRICO } \\
\left(\mathrm{H}_{2} \mathrm{SO}_{4} \mathrm{l}: 1\right)\end{array}$} & \multirow[t]{2}{*}{$\underset{(\mathrm{Ki})}{\operatorname{sio} \mathrm{All}_{2} \mathrm{AO}_{3}}$} & \multirow[t]{2}{*}{$\begin{array}{c}\operatorname{sio}{ }_{2} R_{2} Q_{3} \\
\left|K_{r}\right|\end{array}$} & \multirow[t]{2}{*}{$\mathrm{Al}_{2} \mathrm{~A}_{3} \mathrm{Fe} \mathrm{O}_{3}$} & \multirow{2}{*}{$\begin{array}{c}\text { CARBONO } \\
\text { ORGÂNICO } \\
\left(\begin{array}{l}(y)\end{array}\right.\end{array}$} & \multirow{2}{*}{$\begin{array}{l}y_{0} \\
(\mathrm{y})\end{array}$} \\
\hline $\mathrm{SiO}_{2}$ & $\mathrm{Al}_{2} \mathrm{O}_{3}$ & $\mathrm{Fe}_{2} \mathrm{f}_{3}$ & & & & & \\
\hline 4,2 & 5,0 & 4,9 & 1,4 & 0,9 & 1,6 & 0,50 & 0,9 \\
\hline 4,0 & 6,5 & 4,8 & 1,0 & 0,7 & 2,1 & 0,40 & 0,7 \\
\hline 7,6 & 8,0 & 4,0 & 1,6 & 0,7 & 3,1 & 0,29 & 0,5 \\
\hline 15,1 & 14,0 & 5,8 & 1,8 & 1,4 & 3,8 & 0,34 & 0,6 \\
\hline 16,3 & 16,0 & 4,1 & 1,7 & 1,5 & 6,1 & 0,23 & 0,4 \\
\hline 11,8 & 11,5 & 5,5 & 1,7 & 1,3 & 3,3 & 0,17 & 0,3 \\
\hline 10,8 & 10,0 & 6,8 & 1,8 & 1,3 & 2,3 & 0,17 & 0,3 \\
\hline 13,2 & 11,0 & 6,3 & 2,0 & 1,4 & 2,7 & 0,11 & 0,2 \\
\hline
\end{tabular}


PERFIL $\mathrm{N}^{\circ}-4$

CLASSIFICAÇÃO - Podzólico Vermelho-Amarelo Eutrófico Tb abrupto A moderado textura arenosa/média relevo suave ondulado.

UNIDADE DE MAPEAMENTO -

LOCALIZAÇÃO, MUNICÍPIO, ESTADO E COORDENADAS - Em Monte Alto (SP), a 1500 metros da "Torre da Record", no sentido da Fazenda Paredão.

SITUAÇÃO, DECLIVE E COBERTURA VEGETAL SOBRE O PERFIL - Trincheira situada no pretérito sopé da Superficie II, cultivo de cebola.

ALTITUDE - 720 metros.

LITOLOGIA - Arenito.

FORMAÇÃO GEOLÓGICA - Formação Marília (Grupo Bauru).

CRONOLOGIA - Cretáceo.

MATERIAL ORIGINÁRIO - Depósito superficial arenoso derivado do arenito da formação Marília.

PEDREGOSIDADE - Ausente.

ROCHOSIDADE - Ausente.

RELEVO LOCAL - Suave ondulado.

RELEVO REGIONAL - Suave ondulado.

EROSÃO - Laminar moderada.

DRENAGEM - Bem drenado.

VEGETAÇÃO PRIMÁRIA - Floresta tropical subcaducifólia.

USO ATUAL - Culturas de cebola e milho.

CLIMA - Cwa da classificação de Köppen.

DESCRITO E COLETADO POR - J. Marques Júnior e I.F. Lepsch. 
Perfil 4. Podzólico Vermelho-Amarelo (PV-3)

$\mathrm{A}_{1}$ - 0-16 cm; bruno-avermelhado-escuro (5YR 3/3, úmida); areia; fraca pequena a média blocos subangulares e pequena granular, ligeiramente duro, friável, não plástico e não pegajoso; transição plana e clara.

$A_{2}$ - 16-30 cm; bruno-avermelhado-escuro (5YR 3/3, úmida); areia; fraca pequena blocos subangulares e pequena granular, macio a ligeiramente duro, friável, não plástico, não pegajoso; transição plana e clara.

E - 30-65 cm; bruno-avermelhado-escuro (5YR 3/3, úmida); areia; fraca pequena a média blocos subangulares e granular pequena; macio, friável, não plástico e não pegajoso; transição plana e abrupta.

$\mathrm{Bt}_{1}$ - 65-104 cm; vermelho-amarelado (5YR 4/6, úmida); franco-argilo-arenoso; moderada pequena a média, blocos subangulares que se desfazem em grânulos; cerosidade moderada comum; duro, friável, plástico e ligeiramente pegajoso; transição plana e gradual.

$\mathrm{Bt}_{2}$ - 104-107 cm; vermelho-amarelado (5YR 4/6, úmida); franco-argilo-arenoso; forte a moderada pequena a média blocos subangulares; cerosidade forte comum; duro, firme, ligeiramente plástico, ligeiramente pegajoso.

Raízes abundantes no $A_{1}$ e $A_{2}$, muitas no E, comuns no $B 1$ e poucas finas no $B 2$. 
PODZÓLICO VERNELHO-AMARELO (BAMBÓ)

\begin{tabular}{|c|c|c|c|c|c|c|c|c|c|c|c|}
\hline \multicolumn{2}{|c|}{ HORIZONTE } & \multicolumn{4}{|c|}{ COMPOSIÇAOO GRANULOMÉTRICA } & \multirow{2}{*}{ 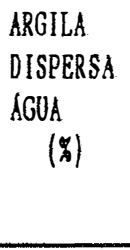 } & \multirow{2}{*}{$\begin{array}{c}\text { GRAU OE } \\
\text { FLOCULAÇAOOO } \\
(x)\end{array}$} & \multirow[t]{2}{*}{$\frac{\text { SILTE }}{\text { ARGILA }}$} & \multicolumn{2}{|c|}{$\begin{array}{c}\text { DENSIDADE } \\
\left(\mathrm{g} / \mathrm{cm}^{3}\right)\end{array}$} & \multirow{2}{*}{$\begin{array}{l}\text { POROSID. } \\
\text { VOLUME } \\
\text { (g) }\end{array}$} \\
\hline SIMBOLO & $\begin{array}{l}\text { PROF. } \\
\text { (C) }\end{array}$ & $\begin{array}{c}\text { AREIA } \\
\text { GROSSA } \\
(y)\end{array}$ & $\begin{array}{c}\text { AREIA } \\
\text { FINA } \\
(y) \\
\end{array}$ & $\begin{array}{l}\text { SILTE } \\
(y) \\
\end{array}$ & $\begin{array}{l}\text { ARGILA } \\
(y) \\
\end{array}$ & & & & APARENTE & REAL & \\
\hline Al & $0-16$ & 50 & 37 & 4 & 9 & 5,7 & 36,6 & 0,44 & 1,61 & 2,56 & 38,02 \\
\hline A2 & $165-30$ & $\$ 1$ & 36 & 3 & 10 & 6,1 & 32,0 & 0,30 & 1,65 & 2,56 & 33,56 \\
\hline$E$ & $30-65$ & 48 & 38 & 4 & 10 & 8,7 & 13,0 & 0,40 & 1,56 & 2,54 & $.37,61$ \\
\hline BHI & $65-104$ & 31 & 32 & 3 & 34 & 31,0 & 8,8 & 0,09 & 1,52 & 2,46 & 40,34 \\
\hline$B+2$ & $104-170$ & 30 & 32 & 3 & 35 & 33,2 & 5,1 & 0,09 & 1,49 & 2,44 & 40,16 \\
\hline Tradagen & $170-210$ & 34 & 35 & 4 & 27 & 25,5 & 5,5 & 0,15 & $\ldots$ & 2,46 & $\ldots$ \\
\hline Tradaget & $210-245$ & 33 & 35 & 4 & 28 & 2,5 & 91,1 & 0,14 & $\ldots$ & 2,48 & $\ldots$ \\
\hline Tradage\# & $245-285$ & 31 & 35 & 3 & 31 & 1,7 & 94,5 & 0,10 & $\ldots$ & 2,44 & $\ldots$ \\
\hline
\end{tabular}

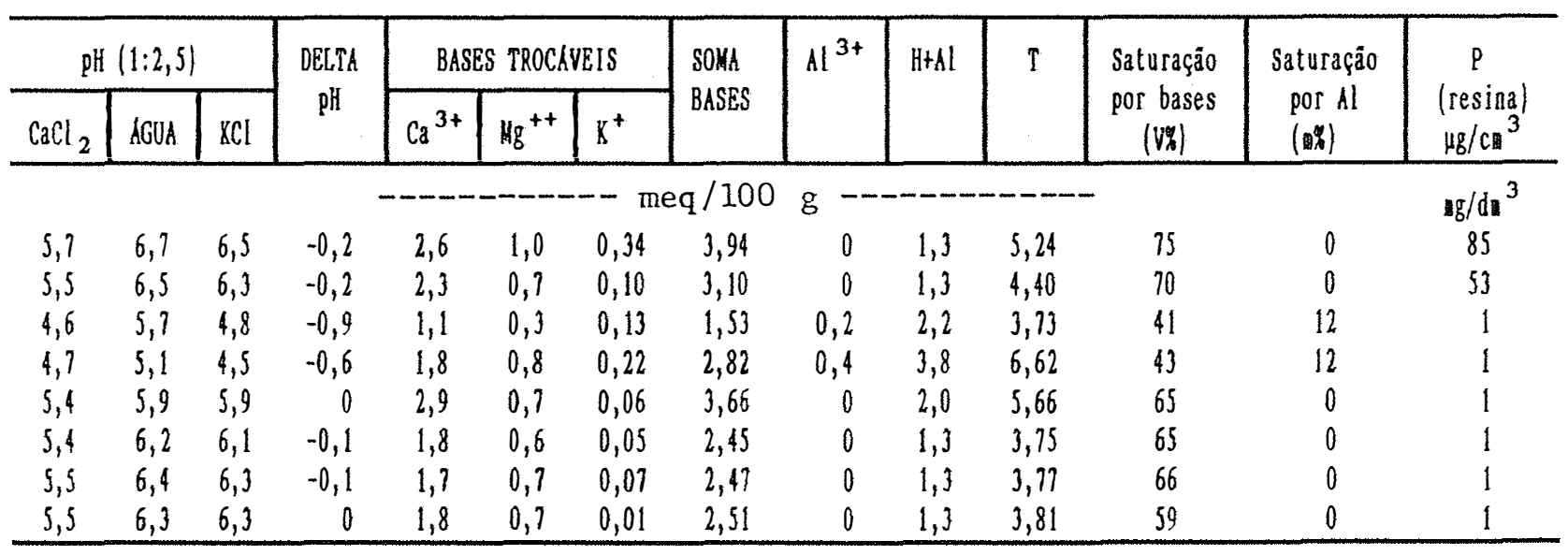

\begin{tabular}{|c|c|c|c|c|c|c|c|}
\hline \multicolumn{3}{|c|}{$\begin{array}{l}\text { ATAQUE SULFÚRICO } \\
\left(\mathrm{H}_{2} \mathrm{SO}_{4} 1: 1\right)\end{array}$} & \multirow[t]{2}{*}{$\underset{(\mathrm{Ki})}{\mathrm{SiO}_{2} \mathrm{All}_{2} \mathrm{O}_{3}}$} & \multirow[t]{2}{*}{$\begin{array}{l}\operatorname{siO}_{2} / R_{2} \theta_{3} \\
\left(X_{I}\right)\end{array}$} & \multirow[t]{2}{*}{$\mathrm{Al}_{2} \mathrm{O}_{3} / \mathrm{Fe}_{2} \mathrm{O}_{3}$} & \multirow{2}{*}{ 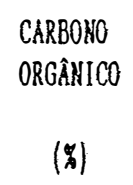 } & \multirow{2}{*}{$\begin{array}{l}\text { no } \\
(\boldsymbol{m})\end{array}$} \\
\hline $\mathrm{SiO}_{2}$ & $\mathrm{Al}_{2} \mathrm{O}_{3}$ & $\mathrm{Fe}_{2} \mathrm{O}_{3}$ & & & & & \\
\hline 4,6 & 6,0 & 2,6 & 1,3 & 1,0 & 3,6 & 0,60 & 1,0 \\
\hline 7,1 & 6,5 & 2,9 & 1,8 & 1,4 & 3,5 & 0,63 & 1,1 \\
\hline 4,5 & 7,0 & 3,3 & 1,1 & 0,8 & 3,3 & 0,41 & 0,7 \\
\hline 15,8 & 15,0 & 4,8 & 1,8 & 1,5 & 4,9 & 0,46 & 0,8 \\
\hline 15,1 & 15,5 & 4,4 & 1,6 & 1,4 & $\$, 5$ & 0,23 & 0,4 \\
\hline 10,5 & 13,0 & 3,3 & 1,3 & 1,2 & 6,2 & 0,20 & 0,3 \\
\hline 9,9 & 13,5 & 4,7 & 1,2 & 1,0 & 4,5 & 0,20 & 0,3 \\
\hline 14,1 & 14,5 & 4,3 & 1,6 & 1,4 & 5,3 & 0,20 & 0,3 \\
\hline
\end{tabular}




\section{PERFIL $\mathrm{N}^{\circ}-5$}

CLASSIFICAÇÃO - Podzólico Vermelho-Amarelo Eutrófico Tb abrupto A moderado textura arenosa/média relevo ondulado.

UNIDADE DE MAPEAMENTO -

LOCALIZAÇÃO, MUNICÍPIO, ESTADO E COORDENADAS - Em Monte Alto (SP), a 1900 metros da "Torre da Record", no sentido da Fazenda Paredão.

SITUAÇÃO, DECLIVE E COBERTURA VEGETAL SOBRE O PERFIL-Trincheira situada no Ombro da Superficie III sob cobertura de gramíneas.

ALTITUDE - 690 metros.

LITOLOGIA - Arenito.

FORMAÇÃO GEOLÓGICA - Formação Marília (Grupo Bauru).

CRONOLOGIA - Cretáceo.

MATERIAL ORIGINÁRIO - Produto de alteração do arenito do Grupo Bauru, e material retrabalhado da encosta.

PEDREGOSIDADE - Ausente.

ROCHOSIDADE - Ausente.

RELEVO LOCAL - Ondulado.

RELEVO REGIONAL - Ondulado a forte ondulado.

EROSÃO - Laminar moderado, com presença de sulcos e pequenas voçorocas.

DRENAGEM - Bem drenado.

VEGETAÇÃO PRIMÁRIA - Floresta tropical subcaducifólia.

USO ATUAL - Pastagem natural.

CLIMA - Cwa da classificação de Köppen.

DESCRITO E COLETADO POR - J. Marques Júnior e I.F. Lepsch. 
Perfil 5. Pozólico Vermelho-Amarelo (PV-4)

$A_{1}$ - 0-12 cm; bruno-avermelhado-escuro (5YR 3/4, úmida); franco arenoso; franca pequena a muito pequena blocos subangulares que se desfazem em grânulos; macio, friável, não plástico, não pegajoso; transição plana e gradual.

$\mathrm{A}_{2}$ - 12-28 cm; bruno-avermelhado-escuro (5YR 3/4, úmida); franco arenoso; fraca média blocos subangulares e fraca pequena granular; macio, friável, não plástico, não pegajoso; transição plana e clara.

E - 28-62 cm; bruno-avermelhado (5YR 4/4, úmida); areia; fraca pequena a média blocos subangulares; macio, friável, não plástico e não pegajoso; transição plana e abrupta.

$\mathrm{Bt}_{1}$ - 61-100 cm; bruno-avermelhado (5YR 4/4, úmida); franco-argilo-arenoso; moderada pequena a média bloco subangular; cerosidade forte e comum; ligeiramente duro, firme a friável, ligeiramente plástico; transição plana e gradual.

$\mathrm{Bt}_{2}$ - 100-150 cm; vermelho-amarelado (5YR 4/6, úmida); franco-argilo-arenoso; moderada média a grande blocos subangulares; cerosidade forte comum; duro, firme, ligeiramente plástico e ligeiramente pegajoso.

Raízes abundantes no $A_{1}$ e $A_{2}$, muitas no $E$, comum no $B_{1}$ e poucas finas no $B_{2}$.

Observações: Presença de lamela de $1 / 2 \mathrm{~cm}$ de espessura no horizonte $\mathrm{E}$ e seixos na parte superior do $\mathrm{B}_{2}$. 
POOZÓLICO VERMELHO-AMARELO (OMBRO)

\begin{tabular}{|c|c|c|c|c|c|c|c|c|c|c|c|}
\hline \multicolumn{2}{|c|}{ HORIZONTE } & \multicolumn{4}{|c|}{ COMPOSIÇÃO GRANULOMÉTRICA } & \multirow{2}{*}{$\begin{array}{l}\text { ARGILA } \\
\text { DISPERSA } \\
\text { SGUA } \\
(\varnothing)\end{array}$} & \multirow{2}{*}{$\begin{array}{c}\text { GRAU DE } \\
\text { FLOCOLAÇÃOO } \\
(\mathbf{m})\end{array}$} & \multirow[t]{2}{*}{$\frac{\text { SILTE }}{\text { ARGILA }}$} & \multicolumn{2}{|c|}{$\begin{array}{c}\text { DENSIOADE } \\
\left(\mathrm{g} / \mathrm{c}^{3}\right)\end{array}$} & \multirow{2}{*}{$\begin{array}{r}\text { POROSID. } \\
\text { VOLUNE } \\
\text { (n) }\end{array}$} \\
\hline SIMBOLO & $\begin{array}{l}\text { PROF. } \\
\text { (c) }\end{array}$ & $\begin{array}{c}\text { AREIA } \\
\text { GROSSA } \\
(y) \\
\end{array}$ & $\begin{array}{l}\text { AREIA } \\
\text { FINA } \\
(y) \\
\end{array}$ & $\begin{array}{l}\text { SILTE } \\
(p) \\
\end{array}$ & $\begin{array}{l}\text { ARGILA } \\
(x)\end{array}$ & & & & APARENTE & REAL & \\
\hline Al & $0-12$ & 46 & 41 & 4 & 9 & 5,6 & 37,7 & 0,44 & 1,38 & 2,56 & 45,00 \\
\hline 12 & $28-62$ & 46 & 41 & 6 & 7 & 6,3 & 10,0 & 0,86 & 1,41 & 2,55 & 46,20 \\
\hline 8 & $28-62$ & 43 & 46 & 5 & $\jmath$ & 5,0 & 16,6 & 0,83 & 1,46 & 2,57 & 41,01 \\
\hline$B+1$ & $62-100$ & 33 & 31 & 3 & 33 & 29,9 & 9,4 & 0,08 & 1,51 & 2,38 & 43,89 \\
\hline Bt2 & $100-150$ & 32 & 36 & 4 & 28 & 26,2 & 6,4 & 0,14 & 1,59 & 2,46 & 43,00 \\
\hline Tradagen & $150-200$ & 39 & 34 & 4 & 23 & 21,4 & 6,9 & 0,17 & $\ldots$ & 2,51 & $\ldots$ \\
\hline Tradage & $200-220$ & 38 & 37 & 5 & 20 & 19,4 & 3,0 & 0,25 & $\ldots$ & 2,51 & $\ldots$ \\
\hline
\end{tabular}

\begin{tabular}{|c|c|c|c|c|c|c|c|c|c|c|c|c|c|}
\hline \multicolumn{3}{|c|}{$\mathrm{pH}(1: 2,5)$} & \multirow{2}{*}{$\begin{array}{c}\text { DELTA } \\
\text { pH }\end{array}$} & \multicolumn{3}{|c|}{ BASES TROCAVEIS } & \multirow{2}{*}{$\begin{array}{l}\text { SOMA } \\
\text { BASES }\end{array}$} & \multirow[t]{2}{*}{$\mathrm{Al}^{3+}$} & \multirow[t]{2}{*}{$\mathrm{H}+\mathrm{Al}$} & \multirow[t]{2}{*}{$T$} & \multirow{2}{*}{$\begin{array}{c}\text { Saturação } \\
\text { por bases } \\
(v /)\end{array}$} & \multirow{2}{*}{ 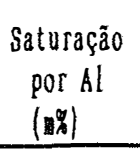 } & \multirow{2}{*}{$\begin{array}{c}\mathrm{P} \\
\text { Lresina } \\
\mu \mathrm{g} / \mathrm{CB} \\
\end{array}$} \\
\hline $\mathrm{CaCl}_{2}$ & AGUA & $\mathrm{KCl}$ & & $\mathrm{Ca}^{3+}$ & $\mathrm{Mg}^{++}$ & $R^{+}$ & & & & & & & \\
\hline & & & & 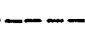 & 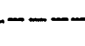 & 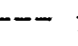 & $q /$ & $g$ & 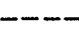 & 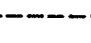 & & & \\
\hline 5,1 & 5,8 & 5,0 & $-0,8$ & 2,2 & 1,0 & 0,01 & 3,21 & 0 & 2,5 & 5,71 & 56 & 0 & 3 \\
\hline 5,0 & 5,9 & $\xi, l$ & $-0,8$ & 2,4 & 0,5 & 0,01 & 2,91 & 0 & 2,5 & 5,41 & 54 & 0 & 2 \\
\hline 5,0 & 6,1 & 5,1 & $-1,0$ & 1,9 & 0,3 & 0,01 & 2,21 & 0 & 1,8 & 4,01 & 55 & 0 & 1 \\
\hline 5,2 & 5,8 & 4,6 & $-1,2$ & 5,2 & 1,4 & 0,13 & 6,73 & 0,2 & 3,4 & 10,13 & 66 & 2 & 1 \\
\hline 5,3 & 6,2 & 5,1 & $-1,1$ & 4,3 & 1,7 & 0,26 & 6,26 & 0 & 2,5 & 8,76 & 11 & 0 & 1 \\
\hline 5,5 & 6,5 & 5,6 & $-0,9$ & 3,3 & 1,8 & 0,29 & 5,39 & 0 & 2,0 & 7,39 & 73 & 0 & 1 \\
\hline 5,6 & 6,4 & 5,7 & $-0,7$ & 2,9 & 1,9 & 0,26 & 5,06 & 0 & 2,0 & 7,06 & 72 & 0 & 1 \\
\hline
\end{tabular}

\begin{tabular}{|c|c|c|c|c|c|c|c|}
\hline \multicolumn{3}{|c|}{$\begin{array}{l}\text { ATAQUE SULF́́RICO } \\
\left(\mathrm{H}_{2} \mathrm{SO}_{4} 1: 1\right)\end{array}$} & \multirow[t]{2}{*}{$\underset{(\mathrm{Ki})}{\mathrm{SiO}_{2} \mathrm{ALI}_{2} \mathrm{O}_{3}}$} & \multirow[t]{2}{*}{$\begin{array}{c}\operatorname{SiO}_{2} / R_{2} \mathrm{O}_{3} \\
(\mathrm{R} T)\end{array}$} & \multirow[t]{2}{*}{$\mathrm{Al}_{2} \mathrm{Fe}_{2} \mathrm{~F}_{3}$} & \multirow{2}{*}{$\begin{array}{c}\text { CARBOHO } \\
\text { ORGÂNICO } \\
(\boldsymbol{y})\end{array}$} & \multirow{2}{*}{ 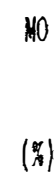 } \\
\hline $\mathrm{SiO}_{2}$ & $\mathrm{Al}_{2} \mathrm{O}_{3}$ & $\mathrm{Fe}_{2} \mathrm{O}_{3}$ & & & & & \\
\hline 2,0 & 4,5 & 1,6 & 0,7 & 0,6 & 4,4 & 0,75 & 1,3 \\
\hline 4,0 & 4,0 & 0,9 & 1,7 & 1,6 & 6,8 & 0,63 & 1,1 \\
\hline 1,4 & 4,5 & 0,5 & 0,5 & 0,5 & 14,1 & 0,29 & 0,5 \\
\hline 15,1 & $10, \xi$ & 1,0 & 2,4 & 2,4 & 16,5 & 0,52 & 0,9 \\
\hline 15,1 & 10,0 & 1,4 & 2,5 & 2,3 & 11,2 & 0,34 & 0,6 \\
\hline 12,9 & 8,0 & 0,6 & 2,7 & 2,6 & 20,9 & 0,17 & 0,3 \\
\hline 12,0 & 7,5 & 1,8 & 2,7 & 2,3 & 6,5 & 0,17 & 0,3 \\
\hline
\end{tabular}


PERFIL N $\mathrm{N}^{\circ}-6$

CLASSIFICAÇÃO - Cambissolo Eutrófico Ta A moderado arenoso cascalhento relevo ondulado.

UNIDADE DE MAPEAMENTO -

LOCALIZAÇÃO, MUNICÍPIO, ESTADO E COORDENADAS - Em Monte Alto (SP), a 2400 metros da "Torre da Record", no sentido da Fazenda Paredão, 48³0’W e $21^{\circ} 15^{\prime} \mathrm{S}$.

SITUAÇÃO, DECLIVE E COBERTURA VEGETAL SOBRE O PERFIL - Trincheira situada no sopé de transporte sob cobertura de gramíneas.

ALTITUDE - 620 metros.

LITOLOGIA - Arenito.

FORMAÇÃO GEOLÓGICA - Formação Marília (Grupo Bauru).

CRONOLOGIA - Cretáceo.

MATERIAL ORIGINÁRIO - Produto de alteração do arenito do Grupo Bauru, e material retrabalhado da escarpa.

PEDREGOSIDADE - Ausente.

ROCHOSIDADE - Ausente.

RELEVO LOCAL - Ondulado.

RELEVO REGIONAL - Ondulado a forte ondulado.

EROSÃO - Laminar moderado e em pequenos sulcos.

DRENAGEM - Moderadamente drenado.

VEGETAÇÃO PRIMÁRIA - Floresta tropical caducifólia.

USO ATUAL - Pastagem natural.

CLIMA - Cwa da classificação de Köppen.

DESCRITO E COLETADO POR - J. Marques Júnior e I.F. Lepsch. 
Perfil 6. Cambissolo

A - 0-21 cm; bruno avermelhado-escuro (5YR 3/2, úmida); franco-arenoso; moderada a fraca pequena a média granular, ligeiramente duro, friável, ligeiramente plástico, não pegajoso; transição plana e clara.

A/B - 21-30 cm; bruno-avermelhado-escuro (5YR 3/2, úmida); areia franca; moderada a fraca pequena blocos subangulares; ligeiramente duro, friável, ligeiramente plástico, ligeiramente pegajoso; transição ondulada e clara.

$\mathrm{Bi}$ - 30-45 cm; vermelho-amarelado (5YR 4/6, úmida); areia; fraca médias a grandes blocos subangulares; ligeiramente duro, friável, ligeiramente plástico, ligeiramente pegajoso; transição plana e clara.

CR-45-57+; vermelho-amarelado (5YR 5/6, úmida); areia; fraca pequena granular; macio friável, não plástico, não pegajoso.

Raízes abundantes no A e A/B, comuns no $\mathrm{Bi}$ e raras no $\mathrm{CR}$.

Observações: Fragmentos de rocha ocupam aproximadamente $10 \%$ do $\mathrm{A} / \mathrm{B}, 20 \%$ do $\mathrm{Bi}$ e $50 \%$ no $\mathrm{CR}$. 
Carbissolo

\begin{tabular}{|c|c|c|c|c|c|c|c|c|c|c|c|}
\hline \multicolumn{2}{|c|}{ HORI ZONTE } & \multicolumn{4}{|c|}{ COMPOSIÇTO GRANULOMÉTRICA } & \multirow{2}{*}{$\begin{array}{l}\text { ARGILA } \\
\text { DISPERSA } \\
\text { SQUA } \\
(x)\end{array}$} & \multirow{2}{*}{$\begin{array}{l}\text { GRAU DE } \\
\text { ELOCOLAÇÃO } \\
(x)\end{array}$} & \multirow[t]{2}{*}{$\frac{\text { SILTE }}{\text { ARGILA }}$} & \multicolumn{2}{|c|}{$\begin{array}{c}\text { DENSIDADE } \\
\left.(\mathrm{g} / \mathrm{C})^{3}\right)\end{array}$} & \multirow{2}{*}{ 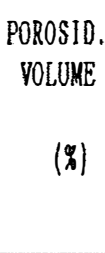 } \\
\hline SIMBOLO & $\begin{array}{l}\text { PROF. } \\
\text { (ca) }\end{array}$ & $\begin{array}{c}\text { AREIA } \\
\text { GROSSA } \\
(y)\end{array}$ & $\begin{array}{l}\text { AREIA } \\
\text { FINA } \\
(y)\end{array}$ & $\begin{array}{l}\text { SILTE } \\
(x)\end{array}$ & $\begin{array}{l}\text { ARGILA } \\
\left.\qquad \begin{array}{l}(x) \\
\end{array}\right)\end{array}$ & & & & APARERTE & REAL & \\
\hline$A$ & $0-12$ & 30 & 46 & 10 & 14 & 10,4 & 25,4 & 0,71 & 1,36 & 2,41 & 45,07 \\
\hline$A / B$ & $12-30$ & 27 & 53 & 10 & 10 & 9,6 & 4,0 & 1,00 & 1,50 & 2,40 & 46,41 \\
\hline$B \mathrm{i}$ & $30-45$ & 34 & 54 & 8 & 4 & 7,8 & 0 & 2,00 & 1,54 & 2,42 & 40,74 \\
\hline$C R$ & $45-57 t$ & 39 & 52 & 1 & 2 & 6,8 & 0 & 3,50 & $\ldots$ & 2,49 & .. \\
\hline
\end{tabular}

\begin{tabular}{|c|c|c|c|c|c|c|c|c|c|c|c|c|c|}
\hline \multicolumn{3}{|c|}{$\mathrm{pH}(1: 2,5)$} & \multirow{2}{*}{$\begin{array}{c}\text { DELTA } \\
\mathrm{pH}\end{array}$} & \multicolumn{3}{|c|}{ BASES TROCSVEIS } & \multirow{2}{*}{$\begin{array}{l}\text { SOHA } \\
\text { BASES }\end{array}$} & \multirow[t]{2}{*}{$\mathrm{Al}^{3+}$} & \multirow[t]{2}{*}{$H+A L$} & \multirow[t]{2}{*}{$\mathrm{T}$} & \multirow{2}{*}{$\begin{array}{c}\text { Saturação } \\
\text { por bases } \\
(\text { Vo })\end{array}$} & \multirow{2}{*}{$\begin{array}{c}\text { Saturação } \\
\text { por Al } \\
(\text { Ax) }\end{array}$} & \multirow{2}{*}{$\begin{array}{c}\mathrm{p} \\
\text { (resina) } \\
\mu \mathrm{g} / \mathrm{cm}^{3} \\
\end{array}$} \\
\hline $\mathrm{CaCl}_{2}$ & SGUA & $\mathrm{KCl}$ & & $\mathrm{Ca}^{3+}$ & $\mathrm{Mg}^{++}$ & $x^{+}$ & & & & & & & \\
\hline & & & & & & & & & & & & & \\
\hline 5,4 & 6,0 & 5,0 & $-1,0$ & 12,4 & 1,5 & 0,16 & 14,06 & 0 & 3,4 & 17,46 & 81 & 0 & 14 \\
\hline 5,5 & 6,2 & 5,0 & $-1,2$ & 13,2 & 1,0 & 0,04 & 14,24 & 0 & 2,8 & 17,04 & 84 & 0 & 21 \\
\hline 3,6 & 6,6 & 5,3 & $-1,3$ & 11,4 & 1,0 & 0,15 & 12,55 & 0 & 1,8 & 14,35 & 87 & 0 & 28 \\
\hline$\rho, 9$ & 6,8 & 6,0 & $-0,8$ & 11,0 & 0,9 & 0,07 & 11,97 & 0 & 1,1 & 13,07 & 92 & 0 & 35 \\
\hline
\end{tabular}

\begin{tabular}{|c|c|c|c|c|c|c|c|}
\hline \multicolumn{3}{|c|}{$\begin{array}{l}\text { ATAQUE SULFÚRICO } \\
\left(\mathrm{H}_{2} \mathrm{SO}_{4} \mathrm{~L}: 1\right)\end{array}$} & \multirow[t]{2}{*}{$\begin{array}{c}\operatorname{SiO}_{2} / \mathrm{Al}_{2} \mathrm{O}_{3} \\
(\mathrm{Ki})\end{array}$} & \multirow[t]{2}{*}{$\begin{array}{l}\operatorname{SiO}_{2} / R_{2} \mathrm{O}_{3} \\
(\mathrm{Kr})\end{array}$} & \multirow[t]{2}{*}{$\mathrm{Al}_{2} \mathrm{O}_{3} \mathrm{Fe}_{2} \mathrm{O}_{3}$} & \multirow{2}{*}{$\begin{array}{c}\text { CARBONO } \\
\text { ORGSNICO } \\
(\%)\end{array}$} & \multirow{2}{*}{$\begin{array}{l}\text { Mo } \\
(y)\end{array}$} \\
\hline $\mathrm{SiO}_{2}$ & $\mathrm{Al}_{2} \mathrm{D}_{3}$ & $\mathrm{Fe}_{2} \mathrm{O}_{3}$ & & & & & \\
\hline 10,7 & 6,5 & 2,9 & 2,8 & $\imath, 1$ & 3,5 & 1,56 & 2,7 \\
\hline 15,0 & 6,0 & 1,3 & 4,2 & 3,7 & 7,2 & 0,69 & 1,2 \\
\hline 12,8 & 6,5 & 1,5 & 3,3 & 2,9 & 6,8 & 0,17 & 0,3 \\
\hline 12,2 & 4,0 & 1,9 & 5,1 & 3,9 & 3,3 & 0,05 & 0,1 \\
\hline
\end{tabular}


PERFIL $\mathrm{N}^{\circ}-7$

CLASSIFICAÇÃO - Brunizém textura média relevo suave ondulado.

UNIDADE DE MAPEAMENTO - B.

LOCALIZAÇÃO, MUNICÍPIO, ESTADO E COORDENADAS - Em Monte Alto (SP), a 2500 metros da "Torre da Record", no sentido da Fazenda Paredão, 48³0' W a $21^{\circ} 15^{\prime} \underline{\text { S. }}$.

SITUAÇÃO, DECLIVE E COBERTURA VEGETAL SOBRE O PERFIL - Trincheira situada no sopé de deposição sob cobertura de gramíneas.

ALTITUDE - 600 metros.

LITOLOGIA - Arenito.

FORMAÇÃO GEOLÓGICA - Formação Marília (Grupo Bauru).

CRONOLOGIA - Cretáceo.

MATERIAL ORIGINÁRIO - Produto de alteração do arenito do Grupo Bauru e material retrabalhado da escarpa e sopé de transporte.

PEDREGOSIDADE - Ausente.

ROCHOSIDADE - Ausente.

RELEVO LOCAL - Suave ondulado.

RELEVO REGIONAL - Suave ondulado a ondulado.

EROSÃO - Laminar moderada.

DRENAGEM - Mal drenado.

VEGETAÇÃO PRIMÁRIA - Floresta tropical subcaducifólia.

USO ATUAL - Pastagem natural.

CLIMA - Cwa da classificação de Köppen.

DESCRITO E COLETADO POR - J. Marques Júnior e I.F. Lepsch. 


\section{BRUNIZÉM}

$A_{1}$ - 0-16 cm - bruno-avermelhado-escuro (5YR 2,5/2, úmida); areia franca, fraca pequena a média granular, macio, friável, não plástico, não pegajoso; transição plana gradual.

$\mathrm{A}_{2}$ - 16-31 cm - bruno-avermelhado-escuro (5YR 3/2, úmida); franco-arenoso; fraca pequena a média granular; macio, friável, não plástico, não pegajoso; transição plana gradual.

E - 31-62 cm - bruno-escuro (7,5YR 3/2, úmida); areia; fraca muito pequena a pequena granular; macio, muito friável, não plástico, não pegajoso; transição ondulada gradual.

$\mathrm{Bt}_{1}-62-81 \mathrm{~cm}$ - bruno-escuro (7,5YR 3/2, úmida); areia franca; fraca pequena a muito pequena blocos subangulres; macio, friável, não plástico, não pegajoso; transição plana gradual.

$\mathrm{Bt}_{2}$ - 81-113 - bruno-escuro (7,5YR 3/2, úmida); franco arenoso: fraca a moderada pequena blocos subangulares; macio, friável, ligeiramente plástico, ligeiramente pegajoso.

Raízes abundantes no $\mathrm{A}_{1}, \mathrm{~A}_{2}$, muitas no $\mathrm{E}$, comuns no $\mathrm{Bt}_{1}$ e poucas no $\mathrm{Bt}_{2}$;

Presença de fendas de $1 \mathrm{~cm}$ de largura e $5 \mathrm{~cm}$ de comprimento no $\mathrm{Bt}_{2}$;

Presença de "lentes de areia" na base e na parte mediana do E. 
BRONIZÉ

\begin{tabular}{|c|c|c|c|c|c|c|c|c|c|c|c|}
\hline \multicolumn{2}{|c|}{ HORI ZONTE } & \multicolumn{4}{|c|}{ COMPOSIÇÃO GRANULONÉTRICA } & \multirow{2}{*}{$\begin{array}{l}\text { ARGILA } \\
\text { OISPERSA } \\
\text { KGUA } \\
\quad(\$)\end{array}$} & \multirow{2}{*}{ 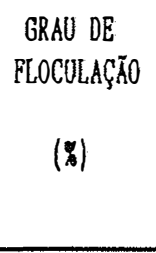 } & \multirow[t]{2}{*}{$\frac{\text { SILTE }}{\text { ARGILA }}$} & \multicolumn{2}{|c|}{$\begin{array}{c}\text { DENSIDADE } \\
\left(\mathrm{g} / \mathrm{ca}^{3}\right)\end{array}$} & \multirow{2}{*}{$\begin{array}{r}\text { POROSID. } \\
\text { VOLOKE } \\
(y)\end{array}$} \\
\hline SINBOLO & $\begin{array}{l}\text { PROE. } \\
\text { (C) }\end{array}$ & $\begin{array}{c}\text { AREIA } \\
\text { GROSSA } \\
(\$)\end{array}$ & $\begin{array}{c}\text { AREIA } \\
\text { FINA } \\
\left(\begin{array}{l}(x) \\
\end{array}\right.\end{array}$ & $\begin{array}{l}\text { SILTE } \\
(x)\end{array}$ & $\begin{array}{l}\text { ARGILA } \\
(x)\end{array}$ & & & & APARENTE & REAL & \\
\hline Al & $0-16$ & 44 & 34 & 8 & 14 & 11 & 21,4 & 0,97 & 1,41 & 2,45 & 41,46 \\
\hline 12 & $16-31$ & 37 & 42 & 5 & 16 & 13 & 18,7 & 0,53 & 1,39 & 2,47 & 37,62 \\
\hline$E$ & $31-62$ & 45 & 44 & 4 & 7 & 7 & 0 & 0,97 & 1,42 & 2,55 & 37,07 \\
\hline BtI & $62-81$ & 46 & 35 & 6 & 13 & 13 & 0 & 0,78 & 1,52 & 2,52 & 39,38 \\
\hline Bt2 & $81-111$ & 50 & 30 & 5 & 15 & 14 & 6,6 & 0,57 & 1,60 & 2,36 & 33,58 \\
\hline Tradagen & $113-253$ & 21 & 46 & 11 & 22 & 25 & 0 & 0,85 & $\ldots$ & 2,46 & $\ldots$ \\
\hline Tradage & $253-293$ & 54 & 31 & 4 & 11 & 14 & 0 & 0,62 & $\ldots$ & 2,53 & $\ldots$ \\
\hline Tradage & $293-33\}$ & 64 & 27 & 2 & 7 & 11 & 0 & 0,49 & $\ldots$ & 2,57 & $\ldots$ \\
\hline
\end{tabular}

\begin{tabular}{|c|c|c|c|c|c|c|c|c|c|c|c|c|c|}
\hline \multicolumn{3}{|c|}{$\mathrm{pH}(1: 2,5)$} & \multirow{2}{*}{$\begin{array}{c}\text { DELTA } \\
\mathrm{pH}\end{array}$} & \multicolumn{3}{|c|}{ BASES TROCAVEIS } & \multirow{2}{*}{$\begin{array}{l}\text { SOMA } \\
\text { BASES }\end{array}$} & \multirow[t]{2}{*}{$\mathrm{Al}^{3+}$} & \multirow[t]{2}{*}{$\mathrm{H}+\mathrm{Al}$} & \multirow[t]{2}{*}{$\mathrm{T}$} & \multirow{2}{*}{$\begin{array}{c}\text { Saturação } \\
\text { por bases } \\
\left.(v)_{0}\right)\end{array}$} & \multirow{2}{*}{$\begin{array}{c}\text { Saturação } \\
\text { por Al } \\
(\mathbf{M})\end{array}$} & \multirow{2}{*}{$\begin{array}{c}\mathrm{p} \\
\text { (resina) } \\
\mu \mathrm{g} / \mathrm{cm}^{3}\end{array}$} \\
\hline $\mathrm{CaCl}_{2}$ & AGOA & $\mathrm{KCl}$ & & $\mathrm{Ca}^{3+}$ & $\mathrm{Hg}^{++}$ & $R^{+}$ & & & & & & & \\
\hline & & & & 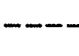 & 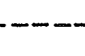 & - & 17 & $\mathrm{~g}$ & 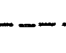 & & & & \\
\hline 5,1 & 5,5 & 4,8 & $-0,7$ & 10,0 & 2,0 & 0,09 & 12,09 & 0,1 & 3,1 & 15,19 & 80 & 1 & 31 \\
\hline 5,1 & $5, ?$ & 4,9 & $-0,8$ & 10,4 & 1,7 & 0,08 & 12,18 & 0,1 & 3,1 & 15,28 & 80 & 1 & 24 \\
\hline 5,3 & 6,2 & 5,5 & $-0,7$ & 7,2 & 1,1 & 0,11 & 8,41 & 0,0 & 2,8 & 11,21 & 75 & 0 & 25 \\
\hline 5,5 & 6,3 & 5,7 & $-0,6$ & 10,0 & 1,4 & 0,11 & 11,51 & 0,1 & 2,8 & 14,31 & 80 & 0 & 26 \\
\hline 5,5 & 6,4 & 5,6 & $-0,8$ & 8,9 & 1,4 & 0,15 & 10,45 & 0,0 & 2,0 & 12,45 & 84 & 0 & 6 \\
\hline 6,0 & 6,5 & 5,8 & $-0,7$ & 12,6 & 2,5 & 0,11 & 15,21 & 0,1 & 2,0 & 17,21 & 88 & 0 & 3 \\
\hline 6,0 & 6,9 & 6,0 & $-0,9$ & 6,4 & 1,2 & 0,12 & 7,72 & 0,0 & 1,2 & 8,92 & 87 & 0 & 8 \\
\hline 5,9 & 5,9 & 5,4 & $-0,5$ & 4,6 & 0,9 & 0,07 & 5,57 & 0,0 & 1,0 & 6,57 & 85 & 0 & 9 \\
\hline
\end{tabular}

\begin{tabular}{|c|c|c|c|c|c|c|c|}
\hline \multicolumn{3}{|c|}{$\begin{array}{l}\text { ATAQUE SULFÚRICO } \\
\left(\mathrm{H}_{2} \mathrm{SO}_{4}[: 1)\right.\end{array}$} & \multirow[t]{2}{*}{$\begin{array}{c}\operatorname{sio}_{2}\left(\mathrm{Al}_{2} \mathrm{O}_{3}\right. \\
(\mathrm{Ki})\end{array}$} & \multirow[t]{2}{*}{$\begin{array}{c}\operatorname{sio}_{2} R_{2} Q_{3} \\
\left(K_{T}\right)\end{array}$} & \multirow[t]{2}{*}{$\mathrm{Al}_{2} \mathrm{O}_{3} \mathrm{Fe} \mathrm{Z}_{3}$} & \multirow{2}{*}{ 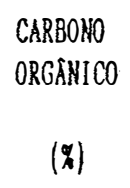 } & \multirow{2}{*}{$\begin{array}{l}\text { no } \\
(x)\end{array}$} \\
\hline $\mathrm{SiO}_{2}$ & $\mathrm{Al}_{2} \mathrm{O}_{3}$ & $\mathrm{Fe}_{2} \mathrm{P}_{3}$ & & & & & \\
\hline 11,0 & 5,0 & 5,3 & 3,7 & $2, \hat{2}$ & 1,4 & 1,68 & 2,9 \\
\hline 1,8 & 5,5 & 7,9 & 3,6 & 1,9 & 1,0 & 1,16 & 2,0 \\
\hline 8,2 & 5,0 & 9,9 & 2,8 & 1,2 & 0,7 & 0,52 & 0,9 \\
\hline 10,6 & 6,0 & 6,7 & 3,0 & 1,7 & 1,4 & 0,93 & 1,6 \\
\hline 10,1 & 4,0 & 8,0 & 4,2 & 1,9 & 0,7 & 0,46 & 0,8 \\
\hline 17,8 & 9,0 & 8,8 & 3,3 & 2,0 & 1,6 & 0,29 & 0,5 \\
\hline 11,1 & 6,5 & 11,4 & 2,9 & 1,3 & 0,9 & 0,12 & 0,2 \\
\hline 8,3 & 5,0 & 9,5 & 2,8 & 1,2 & 0,8 & 0,06 & 0,1 \\
\hline
\end{tabular}


A P E N D I C E 3

RESULTADOS DE ANÁLISES ESTATÍSTICAS DAS PROPRIEDADES QUÍMICAS E FÍSICAS DAS SUPERFÍCIES GEOMÓRFICAS, SEGMENTOS DE VERTENTE E UNIDADES DE MAPEAMENTO DE SOLOS NA ÁREA 
SUPBRPACIR I (12 AMOSTRAS)

\begin{tabular}{|c|c|c|c|c|c|c|c|c|}
\hline \multicolumn{2}{|c|}{ Atributos } & Horizontes & $\begin{array}{l}\text { Valor } \\
\text { Mínimo }\end{array}$ & $\begin{array}{l}\text { Valor } \\
\text { Mázino }\end{array}$ & Hédia & Brro Padrão & $\mathrm{CV}$ & $S$ \\
\hline $\mathrm{PH}$ & & $\begin{array}{l}A \\
B\end{array}$ & $\begin{array}{l}0,6 \\
4,1\end{array}$ & $\begin{array}{l}5,1 \\
5,7\end{array}$ & $\begin{array}{l}4,5 \\
4,7\end{array}$ & $\begin{array}{l}0,38 \\
0,15\end{array}$ & $\begin{array}{l}29,2 \\
11,1\end{array}$ & $\begin{array}{l}1,3 \\
0,5\end{array}$ \\
\hline No & (8) & $\begin{array}{l}A \\
B\end{array}$ & $\begin{array}{l}1,1 \\
0,8\end{array}$ & $\begin{array}{l}2,5 \\
1,6\end{array}$ & $\begin{array}{l}1,9 \\
1,0\end{array}$ & $\begin{array}{l}0,11 \\
0,06\end{array}$ & $\begin{array}{l}21,5 \\
20,2\end{array}$ & $\begin{array}{l}0,4 \\
0,2\end{array}$ \\
\hline$R^{+}$ & & $\begin{array}{l}A \\
B\end{array}$ & $\begin{array}{l}0,08 \\
0,05\end{array}$ & $\begin{array}{l}0,29 \\
0,17\end{array}$ & $\begin{array}{l}0,2 \\
0,1\end{array}$ & $\begin{array}{l}0,02 \\
0,01\end{array}$ & $\begin{array}{l}36,3 \\
38,9\end{array}$ & $\begin{array}{l}0,1 \\
0,0\end{array}$ \\
\hline $\mathrm{Ca}^{++}$ & & $\begin{array}{l}A \\
B\end{array}$ & $\begin{array}{l}0,6 \\
0,7\end{array}$ & $\begin{array}{l}3,9 \\
3,8\end{array}$ & $\begin{array}{l}2,2 \\
2,0\end{array}$ & $\begin{array}{l}0,28 \\
0,27\end{array}$ & $\begin{array}{l}43,9 \\
47,1\end{array}$ & $\begin{array}{l}1,0 \\
1,0\end{array}$ \\
\hline $\mathrm{Ng}^{++}$ & & $\begin{array}{l}A \\
B\end{array}$ & $\begin{array}{l}0,1 \\
0,1\end{array}$ & $\begin{array}{l}1,7 \\
0,7\end{array}$ & $\begin{array}{l}0,8 \\
0,3\end{array}$ & $\begin{array}{l}0,15 \\
0,06\end{array}$ & $\begin{array}{l}63,7 \\
60,3\end{array}$ & $\begin{array}{l}0,5 \\
0,2\end{array}$ \\
\hline $\mathrm{B}+\mathrm{Al}^{3+} \quad$ (nec & $00 \mathrm{gl}$ & $\begin{array}{l}A \\
B\end{array}$ & $\begin{array}{l}2,0 \\
1,6\end{array}$ & $\begin{array}{l}6,4 \\
5,8\end{array}$ & $\begin{array}{l}3,9 \\
3,8\end{array}$ & $\begin{array}{l}0,42 \\
0,38\end{array}$ & $\begin{array}{l}37,3 \\
34,9\end{array}$ & $\begin{array}{l}1,4 \\
1,3\end{array}$ \\
\hline$S B$ & & $\begin{array}{l}A \\
B\end{array}$ & $\begin{array}{l}1,70 \\
0,97\end{array}$ & $\begin{array}{l}5,60 \\
4,42\end{array}$ & $\begin{array}{l}3,3 \\
2,5\end{array}$ & $\begin{array}{l}0,39 \\
0,33\end{array}$ & $\begin{array}{l}41,1 \\
46,0\end{array}$ & $\begin{array}{l}1,4 \\
1,1\end{array}$ \\
\hline I & & $\begin{array}{l}A \\
B\end{array}$ & $\begin{array}{l}4,78 \\
5,20\end{array}$ & $\begin{array}{l}8,16 \\
7,62\end{array}$ & $\begin{array}{l}7,2 \\
6,3\end{array}$ & $\begin{array}{l}0,28 \\
0,19\end{array}$ & $\begin{array}{l}13,7 \\
10,3\end{array}$ & $\begin{array}{l}1,0 \\
0,7\end{array}$ \\
\hline$V$ & $(8)$ & $\begin{array}{l}A \\
B\end{array}$ & $\begin{array}{l}21 \\
16\end{array}$ & $\begin{array}{l}66 \\
73\end{array}$ & $\begin{array}{l}46,8 \\
39,6\end{array}$ & $\begin{array}{l}4,83 \\
5,41\end{array}$ & $\begin{array}{l}36,1 \\
47,4\end{array}$ & $\begin{array}{l}16,7 \\
18,8\end{array}$ \\
\hline Areia grossa & 1 & $\begin{array}{l}A \\
B\end{array}$ & $\begin{array}{l}2,6 \\
1,6\end{array}$ & $\begin{array}{l}5,9 \\
3,9\end{array}$ & $\begin{array}{l}3,7 \\
2,6\end{array}$ & $\begin{array}{l}0,29 \\
0,21\end{array}$ & $\begin{array}{l}27,2 \\
27,8\end{array}$ & $\begin{array}{l}1,0 \\
0,7\end{array}$ \\
\hline Areia fina & ? & $\begin{array}{l}A \\
B\end{array}$ & $\begin{array}{l}18,9 \\
18,6\end{array}$ & $\begin{array}{l}35,3 \\
30,3\end{array}$ & $\begin{array}{l}29,3 \\
26,0\end{array}$ & $\begin{array}{l}1,91 \\
1,11\end{array}$ & $\begin{array}{l}23,0 \\
14,8\end{array}$ & $\begin{array}{l}6,7 \\
3,4\end{array}$ \\
\hline Silte & $\begin{array}{c}(8) \\
i\end{array}$ & $\begin{array}{l}A \\
B\end{array}$ & $\begin{array}{l}0,2 \\
0,2\end{array}$ & $\begin{array}{l}3,1 \\
2,0\end{array}$ & $\begin{array}{l}1,08 \\
1,05\end{array}$ & $\begin{array}{l}0,25 \\
0,14\end{array}$ & $\begin{array}{l}81,5 \\
48,3\end{array}$ & $\begin{array}{l}0,9 \\
0,5\end{array}$ \\
\hline Argila & 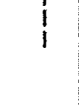 & $\begin{array}{l}A \\
B\end{array}$ & $\begin{array}{l}13 \\
18\end{array}$ & $\begin{array}{l}25 \\
34\end{array}$ & $\begin{array}{l}20,8 \\
28,5\end{array}$ & $\begin{array}{l}0,99 \\
1,33\end{array}$ & $\begin{array}{l}16,6 \\
16,2\end{array}$ & $\begin{array}{l}3,5 \\
4,6\end{array}$ \\
\hline$A I g A / A I g B$ & & & 0,55 & 1,26 & 0,8 & 0,05 & 24,8 & 0,2 \\
\hline Silte/Argila & & $\begin{array}{l}A \\
B\end{array}$ & $\begin{array}{l}0,01 \\
0,01\end{array}$ & $\begin{array}{l}0,24 \\
0,08\end{array}$ & $\begin{array}{l}0,1 \\
0,0\end{array}$ & $\begin{array}{l}0,01 \\
0,00\end{array}$ & $\begin{array}{r}108,1 \\
56,6\end{array}$ & $\begin{array}{l}0,1 \\
0,0\end{array}$ \\
\hline$A P / A G$ & & $\begin{array}{l}A \\
8\end{array}$ & $\begin{array}{l}3,36 \\
4,77\end{array}$ & $\begin{array}{l}13,54 \\
18,94\end{array}$ & $\begin{array}{r}8,8 \\
10,9\end{array}$ & $\begin{array}{l}1,02 \\
1,19\end{array}$ & $\begin{array}{l}40,3 \\
38,1\end{array}$ & $\begin{array}{l}3,5 \\
4,1\end{array}$ \\
\hline
\end{tabular}


SUPBRPICIB II (34 AMOSTRAS)

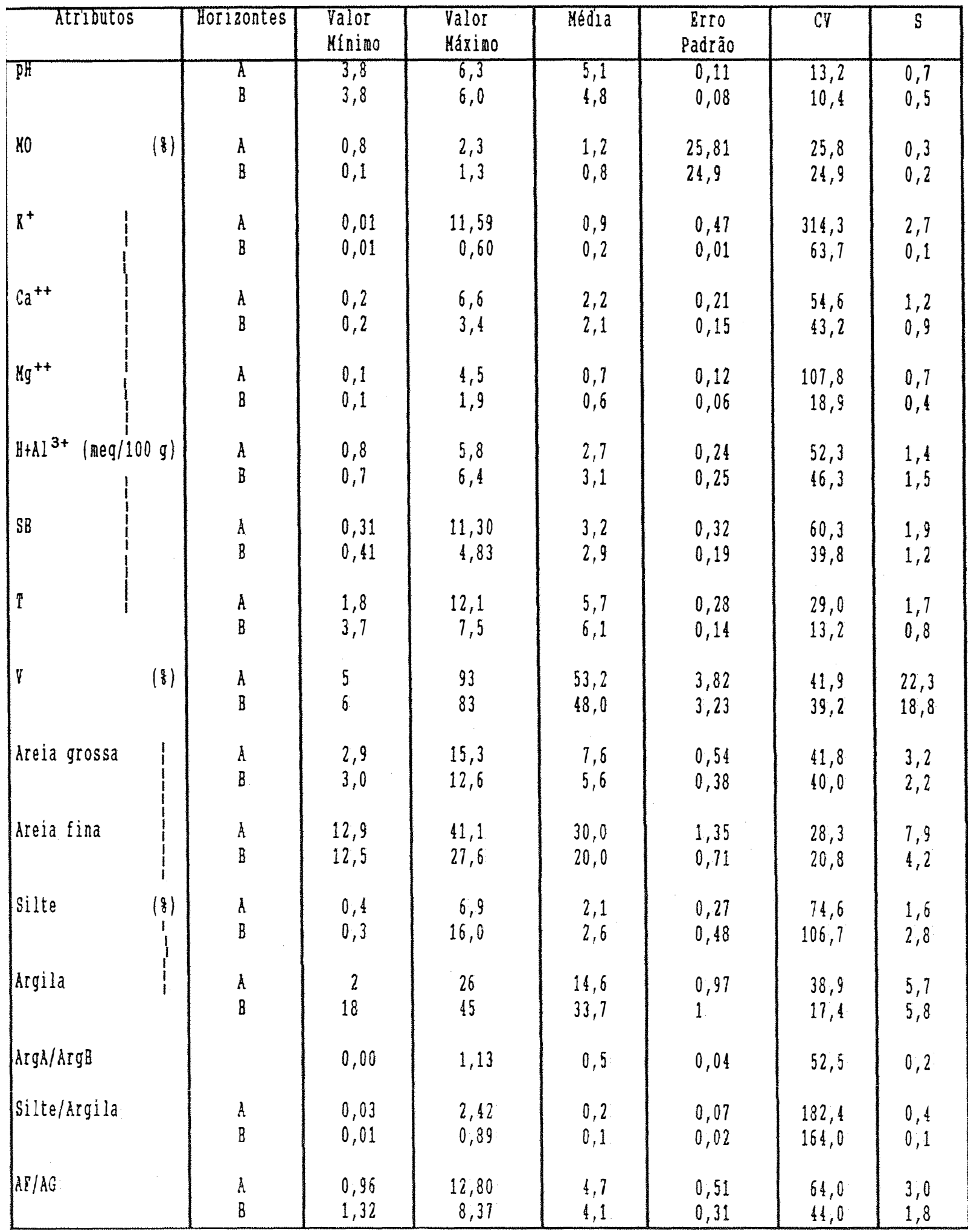


SUPBRETCIR III (42 AMOSTRAS)

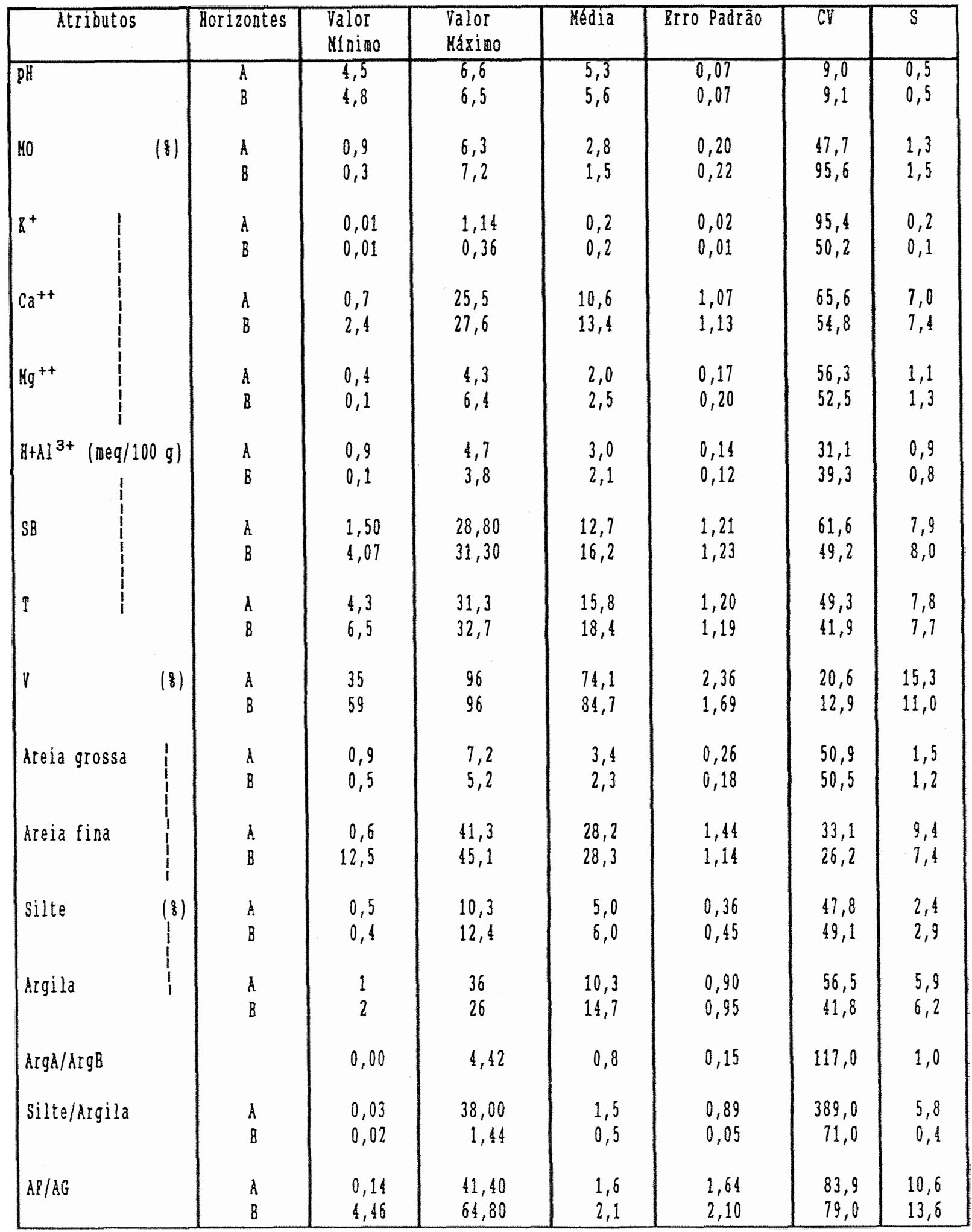


ESTATISTICA DA SOPBRPICIR (TOPO) - 12 amostras.

\begin{tabular}{|c|c|c|c|c|c|c|c|c|}
\hline Atribut & & Horizontes & $\begin{array}{l}\text { Valor } \\
\text { Minimo }\end{array}$ & $\begin{array}{l}\text { Valor } \\
\text { Mázimo }\end{array}$ & Kédia & Erro Padrão & $\mathrm{CH}$ & $S$ \\
\hline $\mathrm{pH}$ & & $\begin{array}{l}1 \\
B\end{array}$ & $\begin{array}{l}0,6 \\
4,1\end{array}$ & $\begin{array}{l}5,4 \\
5,7\end{array}$ & $\begin{array}{l}4,3 \\
4,7\end{array}$ & $\begin{array}{l}0,38 \\
0,15\end{array}$ & $\begin{array}{l}29,2 \\
11,1\end{array}$ & $\begin{array}{l}1,3 \\
0,5\end{array}$ \\
\hline MO & $(8)$ & $\begin{array}{l}A \\
B\end{array}$ & $\begin{array}{l}1,1 \\
0,8\end{array}$ & $\begin{array}{l}2,5 \\
0,8\end{array}$ & $\begin{array}{l}1,9 \\
1,0\end{array}$ & $\begin{array}{l}0,11 \\
0,06\end{array}$ & $\begin{array}{l}21,5 \\
20,2\end{array}$ & $\begin{array}{l}0,4 \\
0,2\end{array}$ \\
\hline $\mathbb{R}^{+}$ & & $\begin{array}{l}A \\
B\end{array}$ & $\begin{array}{l}0,08 \\
0,05\end{array}$ & $\begin{array}{l}0,29 \\
0,17\end{array}$ & $\begin{array}{l}0,2 \\
0,1\end{array}$ & $\begin{array}{l}0,02 \\
0,01\end{array}$ & $\begin{array}{l}36,3 \\
38,9\end{array}$ & $\begin{array}{l}0,1 \\
0,0\end{array}$ \\
\hline $\mathrm{Ca}^{++}$ & & $\begin{array}{l}A \\
B\end{array}$ & $\begin{array}{l}0,6 \\
0,7\end{array}$ & $\begin{array}{l}3,9 \\
3,8\end{array}$ & $\begin{array}{l}2,2 \\
2,0\end{array}$ & $\begin{array}{l}0,28 \\
0,27\end{array}$ & $\begin{array}{l}43,9 \\
47,1\end{array}$ & $\begin{array}{l}1,0 \\
1,0\end{array}$ \\
\hline $\mathrm{Mg}^{++}$ & & $\begin{array}{l}A \\
B\end{array}$ & $\begin{array}{l}0,1 \\
0,1\end{array}$ & $\begin{array}{l}1,7 \\
0,7\end{array}$ & $\begin{array}{l}0,8 \\
0,3\end{array}$ & $\begin{array}{l}0,15 \\
0,06\end{array}$ & $\begin{array}{l}63,7 \\
60,3\end{array}$ & $\begin{array}{l}0,5 \\
0,2\end{array}$ \\
\hline $\mathrm{B}+\mathrm{Al}^{3+} \quad(\mathrm{mec}$ & 0 g) & $\begin{array}{l}A \\
B\end{array}$ & $\begin{array}{l}2,0 \\
1,6\end{array}$ & $\begin{array}{l}6,4 \\
1,6\end{array}$ & $\begin{array}{l}3,9 \\
3,8\end{array}$ & $\begin{array}{l}0,41 \\
0,38\end{array}$ & $\begin{array}{l}37,3 \\
34,9\end{array}$ & $\begin{array}{l}1,5 \\
1,3\end{array}$ \\
\hline SB & & $\begin{array}{l}A \\
B\end{array}$ & $\begin{array}{l}1,70 \\
0,97\end{array}$ & $\begin{array}{l}5,60 \\
4,40\end{array}$ & $\begin{array}{l}3,3 \\
2,5\end{array}$ & $\begin{array}{l}0,40 \\
0,32\end{array}$ & $\begin{array}{l}41,1 \\
46,0\end{array}$ & $\begin{array}{l}1,4 \\
1,1\end{array}$ \\
\hline $\mathrm{T}$ & & $\begin{array}{l}A \\
B\end{array}$ & $\begin{array}{l}4,7 \\
5,2\end{array}$ & $\begin{array}{l}8,1 \\
7,6\end{array}$ & $\begin{array}{l}7,2 \\
6,3\end{array}$ & $\begin{array}{l}0,28 \\
0,18\end{array}$ & $\begin{array}{l}13,7 \\
10,3\end{array}$ & $\begin{array}{l}1,0 \\
0,6\end{array}$ \\
\hline V & $(8)$ & $\begin{array}{l}A \\
B\end{array}$ & $\begin{array}{l}21 \\
16\end{array}$ & $\begin{array}{l}66 \\
73\end{array}$ & $\begin{array}{l}16,4 \\
39,6\end{array}$ & $\begin{array}{l}1,83 \\
5,81\end{array}$ & $\begin{array}{l}36,1 \\
47,4\end{array}$ & $\begin{array}{l}16,7 \\
18,8\end{array}$ \\
\hline Areia grossa & 1 & $\begin{array}{l}A \\
B\end{array}$ & $\begin{array}{l}2,6 \\
1,6\end{array}$ & $\begin{array}{l}5,9 \\
3,9\end{array}$ & $\begin{array}{l}3,7 \\
2,6\end{array}$ & $\begin{array}{l}0,29 \\
0,21\end{array}$ & $\begin{array}{l}27,2 \\
27,8\end{array}$ & $\begin{array}{l}1,0 \\
0,7\end{array}$ \\
\hline Kreia fina & 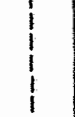 & $\begin{array}{l}A \\
B\end{array}$ & $\begin{array}{l}18,9 \\
18,6\end{array}$ & $\begin{array}{l}35,3 \\
30,3\end{array}$ & $\begin{array}{l}29,3 \\
26,0\end{array}$ & $\begin{array}{l}1,94 \\
1,10\end{array}$ & $\begin{array}{l}23,0 \\
14,8\end{array}$ & $\begin{array}{l}6,7 \\
3,8\end{array}$ \\
\hline Silte & $\begin{array}{c}(8) \\
1 \\
1\end{array}$ & $\begin{array}{l}A \\
B\end{array}$ & $\begin{array}{l}0,2 \\
0,2\end{array}$ & $\begin{array}{l}3,1 \\
2,0\end{array}$ & $\begin{array}{l}1,1 \\
1,1\end{array}$ & $\begin{array}{l}0,26 \\
0,15\end{array}$ & $\begin{array}{l}81,5 \\
48,3\end{array}$ & $\begin{array}{l}0,9 \\
0,5\end{array}$ \\
\hline Argila & $i$ & $\begin{array}{l}A \\
8\end{array}$ & $\begin{array}{l}13 \\
18\end{array}$ & $\begin{array}{l}25 \\
34\end{array}$ & $\begin{array}{l}20,8 \\
28,5\end{array}$ & $\begin{array}{l}0,99 \\
1,33\end{array}$ & $\begin{array}{l}16,6 \\
16,2\end{array}$ & $\begin{array}{l}3,5 \\
1,6\end{array}$ \\
\hline Argh/ArgB & & & 0,55 & 1,26 & 0,8 & 0,05 & 24,82 & 0,2 \\
\hline Silte/Argila & & $\begin{array}{l}A \\
B\end{array}$ & $\begin{array}{l}0,01 \\
0,01\end{array}$ & $\begin{array}{l}0,24 \\
0,08\end{array}$ & $\begin{array}{l}0,1 \\
0,0\end{array}$ & $\begin{array}{l}0,02 \\
0,00\end{array}$ & $\begin{array}{r}108,1 \\
59,7\end{array}$ & $\begin{array}{l}0,1 \\
0,0\end{array}$ \\
\hline$A P / A G$ & & $\begin{array}{l}A \\
B \\
\end{array}$ & $\begin{array}{l}3,36 \\
4,77\end{array}$ & $\begin{array}{l}13,54 \\
18,94 \\
\end{array}$ & $\begin{array}{r}8,8 \\
10,9 \\
\end{array}$ & $\begin{array}{l}1,02 \\
1,19 \\
\end{array}$ & $\begin{array}{l}40,3 \\
38,1 \\
\end{array}$ & $\begin{array}{l}3,6 \\
4,1 \\
\end{array}$ \\
\hline
\end{tabular}


RSTATSSTICA DA SUPERPfCIR II (OMBRO SUP.) - 9 AMOSTRAS

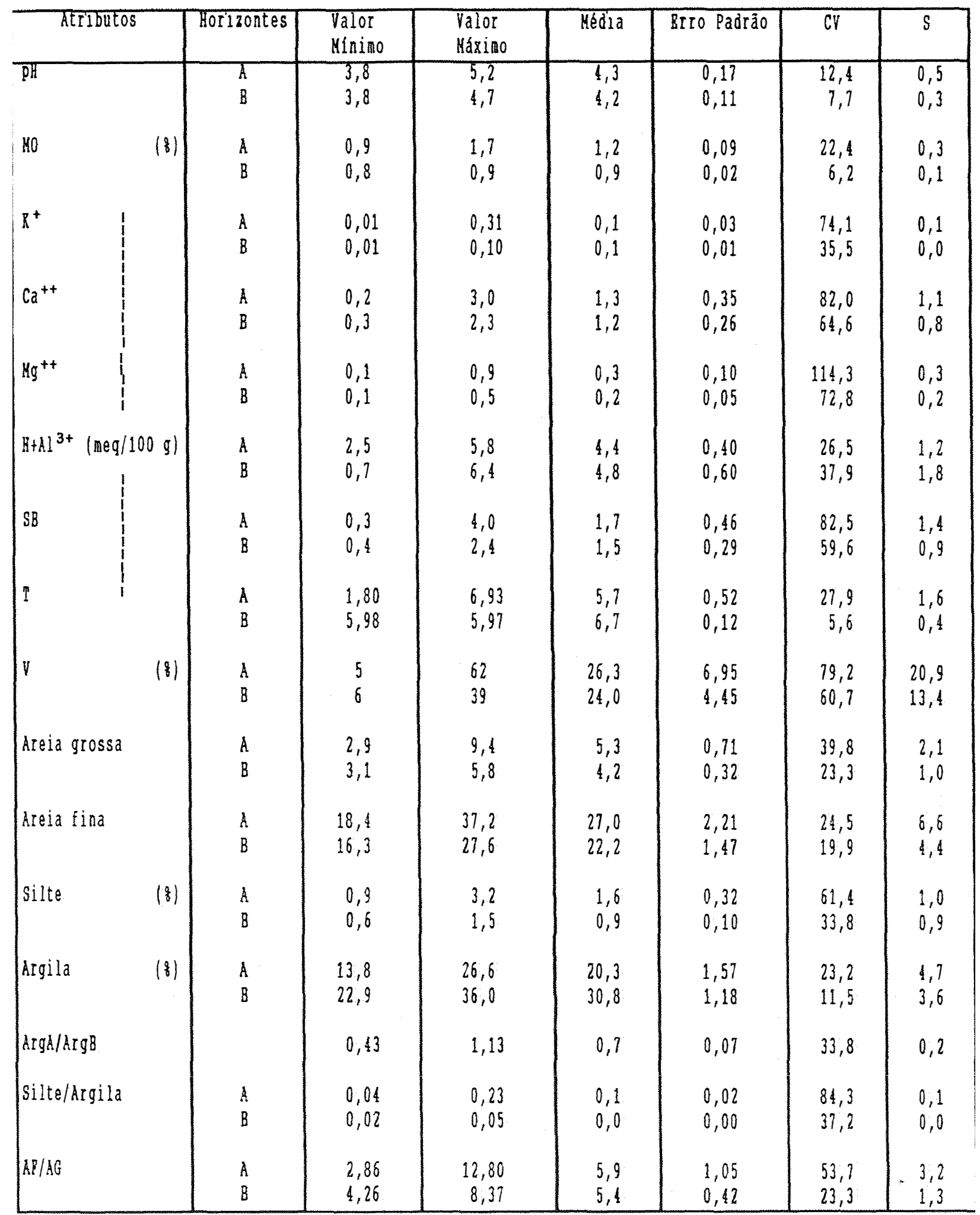


SUPRBPFCIR II (ONBRO INP) - 7 AMOSTRAS

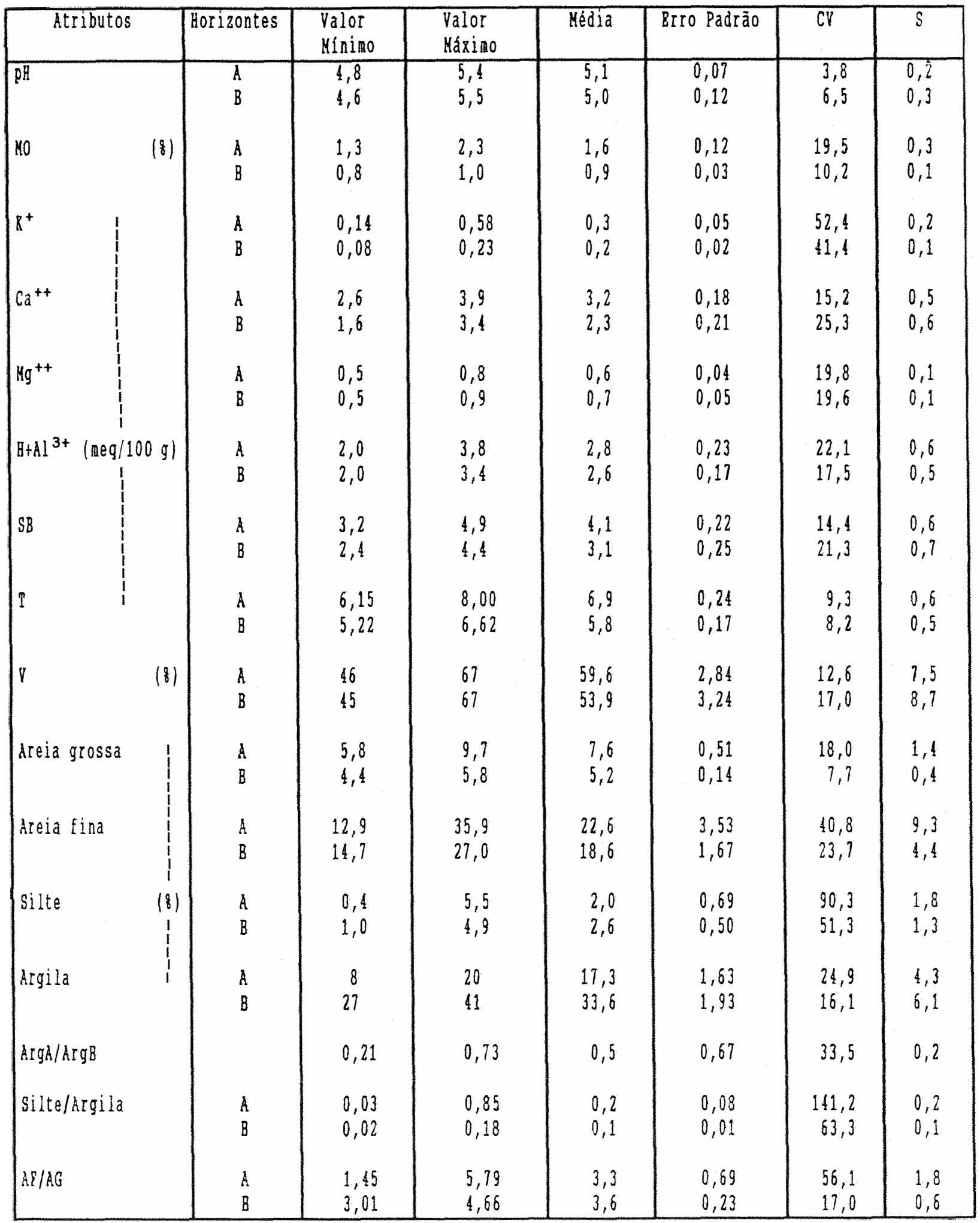


BSTATISTICA DA SUPBRPTCIE II (EKCOSTA SOPE) - 18 AKOSTRAS

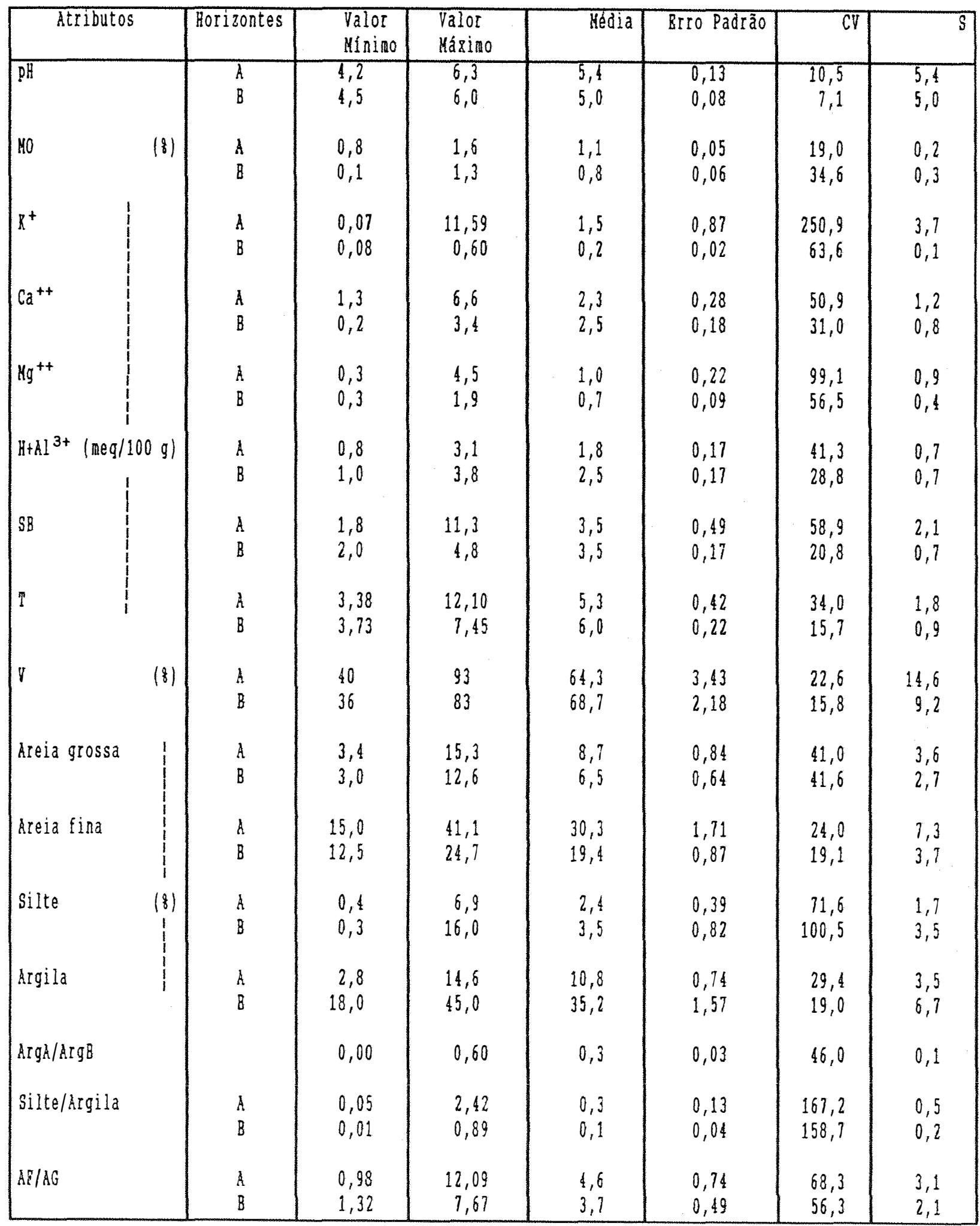


BSTAT TSPICA DA SUPERPACIR III (OMERO) - 12 AMOSTRAS

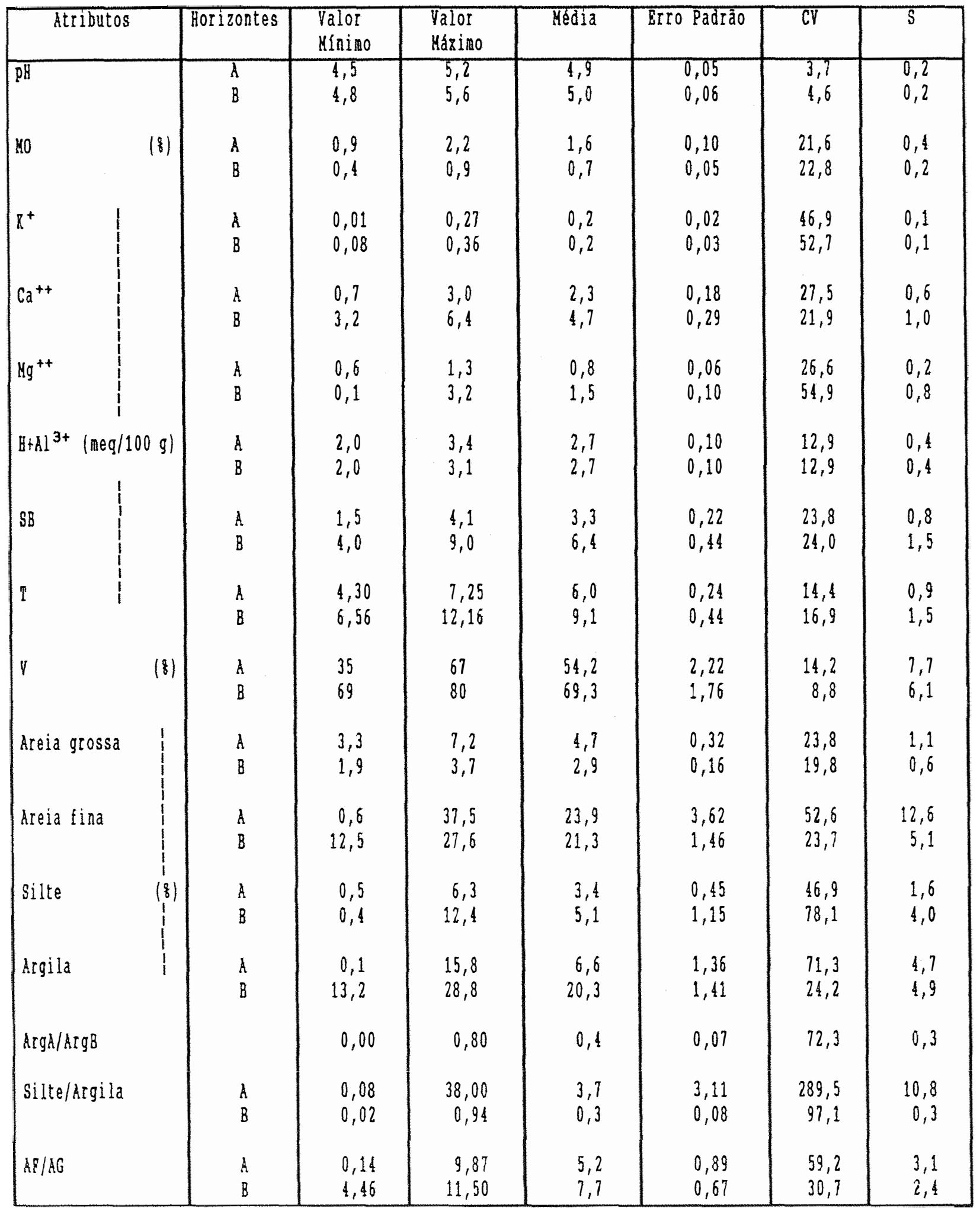


SUPRRPICIR III (ESCARPA) - 9 AMOSTRAS

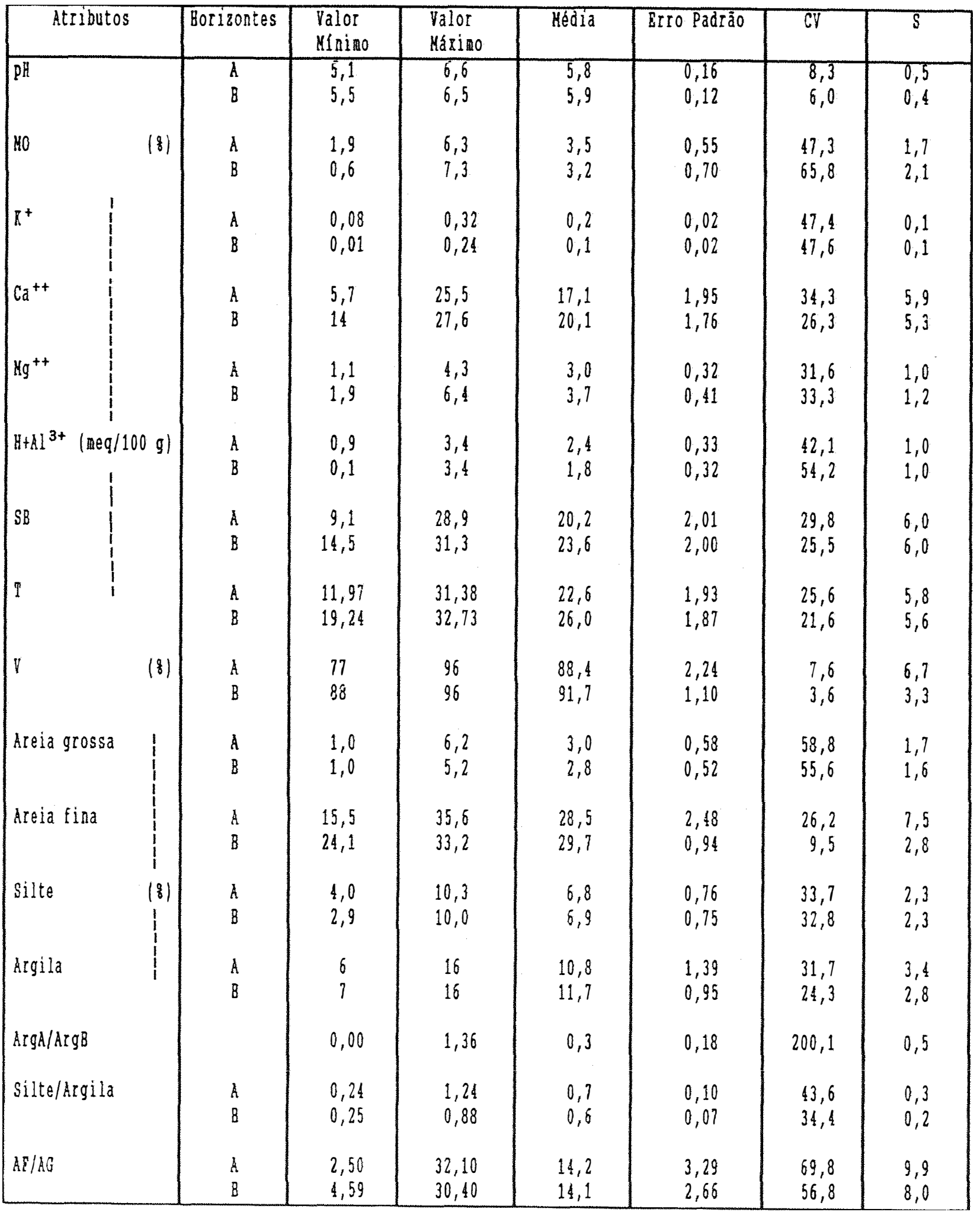


SUPRBPTCIE III (SOPE TRAHSPORTR) - 9 AMOSTRAS

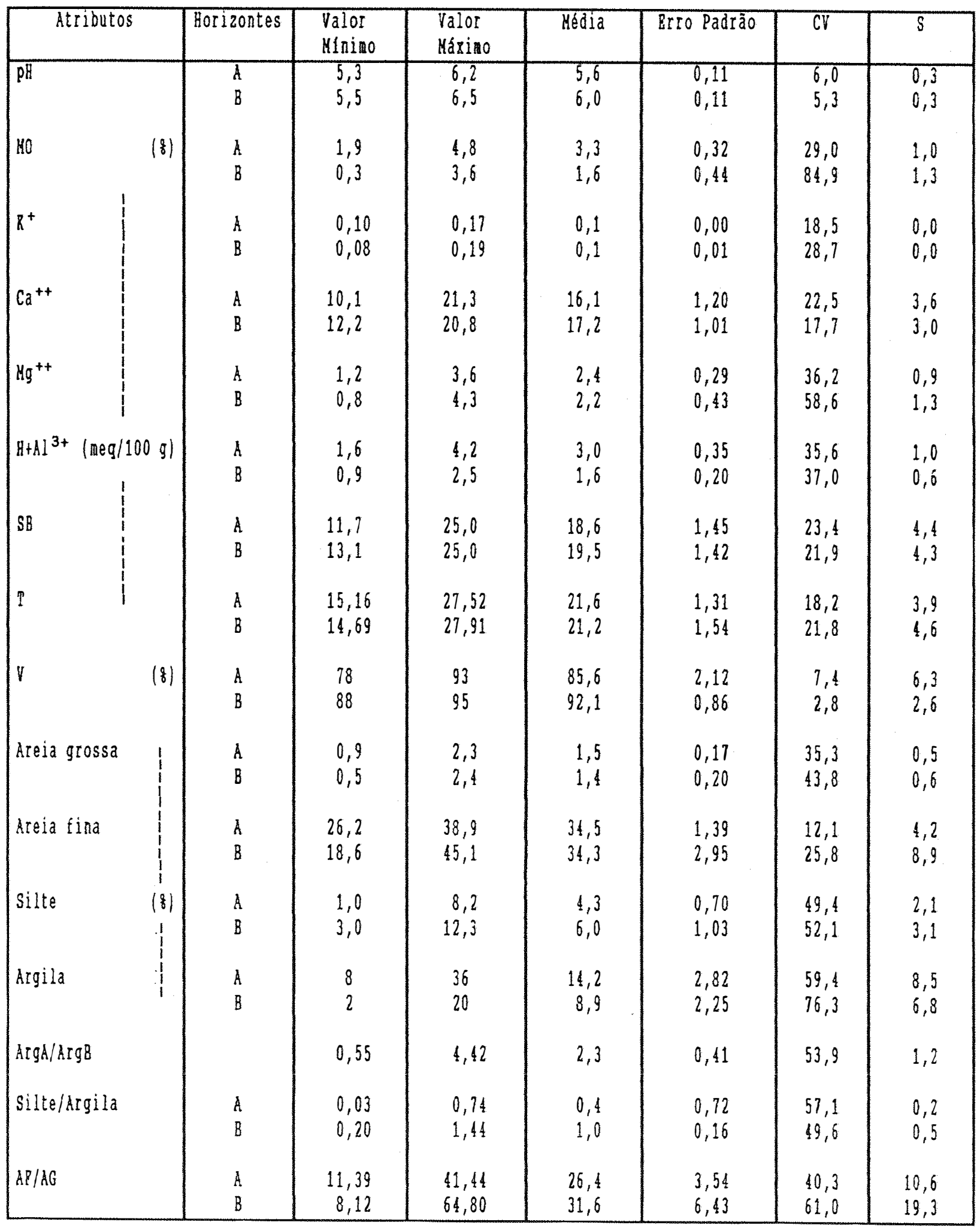


SUPEBPICIE III (SOPE DR DEPOSIÇÃO) - 12 AMOSTRAS

\begin{tabular}{|c|c|c|c|c|c|c|c|c|}
\hline \multicolumn{2}{|l|}{ Atributos } & Horizontes & $\begin{array}{l}\text { Valor } \\
\text { Mínimo }\end{array}$ & $\begin{array}{l}\text { Valor } \\
\text { Máximo }\end{array}$ & Média & Erro Pad̆rão & $\mathrm{CV}$ & $S$ \\
\hline $\mathrm{pH}$ & & $\begin{array}{l}T \\
B\end{array}$ & $\begin{array}{l}4,8 \\
4,8\end{array}$ & $\begin{array}{l}5,7 \\
6,3\end{array}$ & $\begin{array}{l}5,1 \\
5,7\end{array}$ & $\begin{array}{l}0,07 \\
0,12\end{array}$ & $\begin{array}{l}4,6 \\
7,5\end{array}$ & $\begin{array}{l}0,2 \\
0,4\end{array}$ \\
\hline MO & $(8)$ & $\begin{array}{l}A \\
B\end{array}$ & $\begin{array}{l}1,7 \\
0,5\end{array}$ & $\begin{array}{l}5,7 \\
2,0\end{array}$ & $\begin{array}{l}3,2 \\
1,1\end{array}$ & $\begin{array}{l}0,38 \\
0,13\end{array}$ & $\begin{array}{l}40,8 \\
41,9\end{array}$ & $\begin{array}{l}1,3 \\
0,1\end{array}$ \\
\hline 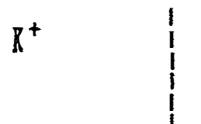 & & $\begin{array}{l}A \\
B\end{array}$ & $\begin{array}{l}0,01 \\
0,10\end{array}$ & $\begin{array}{l}1,14 \\
0,23\end{array}$ & $\begin{array}{l}0,2 \\
0,1\end{array}$ & $\begin{array}{l}0,09 \\
0,01\end{array}$ & $\begin{array}{r}136,0 \\
27,4\end{array}$ & $\begin{array}{l}0,3 \\
0,0\end{array}$ \\
\hline $\mathrm{Ca}^{++}$ & & $\begin{array}{l}A \\
B\end{array}$ & $\begin{array}{l}5,2 \\
2,4\end{array}$ & $\begin{array}{l}14,9 \\
23,6\end{array}$ & $\begin{array}{l}10,0 \\
14,3\end{array}$ & $\begin{array}{l}0,98 \\
1,84\end{array}$ & $\begin{array}{l}33,9 \\
44,7\end{array}$ & $\begin{array}{l}3,4 \\
6,4\end{array}$ \\
\hline $\mathrm{Ng}^{++}$ & & $\begin{array}{l}A \\
\mathbb{B}\end{array}$ & $\begin{array}{l}0,4 \\
0,9\end{array}$ & $\begin{array}{l}3,7 \\
4,1\end{array}$ & $\begin{array}{l}2,0 \\
2,8\end{array}$ & $\begin{array}{l}0,28 \\
0,29\end{array}$ & $\begin{array}{l}48,0 \\
35,7\end{array}$ & $\begin{array}{l}1,0 \\
1,0\end{array}$ \\
\hline $\mathrm{H}+\mathrm{A} \mathrm{I}^{3+}$ (meg/10 & $0 \mathrm{~g})$ & $\begin{array}{l}A \\
B\end{array}$ & $\begin{array}{l}2,5 \\
0,9\end{array}$ & $\begin{array}{l}4,7 \\
3,8\end{array}$ & $\begin{array}{l}3,7 \\
1,9\end{array}$ & $\begin{array}{l}0,21 \\
0,24\end{array}$ & $\begin{array}{l}19,5 \\
43,1\end{array}$ & $\begin{array}{l}0,7 \\
0,8\end{array}$ \\
\hline SB & & $\begin{array}{l}A \\
B\end{array}$ & $\begin{array}{l}5,6 \\
9,8\end{array}$ & $\begin{array}{l}18,2 \\
27,3\end{array}$ & $\begin{array}{l}12,1 \\
18,1\end{array}$ & $\begin{array}{l}1,18 \\
1,68\end{array}$ & $\begin{array}{l}33,7 \\
32,2\end{array}$ & $\begin{array}{l}4,1 \\
5,8\end{array}$ \\
\hline$T$ & & $\begin{array}{l}A \\
B\end{array}$ & $\begin{array}{r}8,71 \\
12,31\end{array}$ & $\begin{array}{l}21,50 \\
28,80\end{array}$ & $\begin{array}{l}16,2 \\
20,0\end{array}$ & $\begin{array}{l}1,31 \\
1,60\end{array}$ & $\begin{array}{l}27,9 \\
27,7\end{array}$ & $\begin{array}{l}4,5 \\
5,5\end{array}$ \\
\hline v & $(8)$ & $\begin{array}{l}A \\
B\end{array}$ & $\begin{array}{l}64 \\
80\end{array}$ & $\begin{array}{l}85 \\
95\end{array}$ & $\begin{array}{l}75,0 \\
89,4\end{array}$ & $\begin{array}{l}1,85 \\
1,71\end{array}$ & $\begin{array}{l}8,6 \\
6,6\end{array}$ & $\begin{array}{l}6,4 \\
5,9\end{array}$ \\
\hline Areia grossa & 1 & $\begin{array}{l}A \\
B\end{array}$ & $\begin{array}{l}1,7 \\
1,0\end{array}$ & $\begin{array}{l}6,5 \\
4,9\end{array}$ & $\begin{array}{l}3,4 \\
2,1\end{array}$ & $\begin{array}{l}0,44 \\
0,35\end{array}$ & $\begin{array}{l}39,4 \\
58,0\end{array}$ & $\begin{array}{l}1,6 \\
1,2\end{array}$ \\
\hline Areia fina & $i$ & $\begin{array}{l}A \\
B\end{array}$ & $\begin{array}{l}11,1 \\
17,9\end{array}$ & $\begin{array}{l}41,3 \\
38,1\end{array}$ & $\begin{array}{l}27,8 \\
29,8\end{array}$ & $\begin{array}{l}2,29 \\
1,58\end{array}$ & $\begin{array}{l}28,7 \\
18,4\end{array}$ & $\begin{array}{l}8,0 \\
5,5\end{array}$ \\
\hline Silte & $\begin{array}{c}(8) \\
1\end{array}$ & $\begin{array}{l}A \\
B\end{array}$ & $\begin{array}{l}2,6 \\
1,7\end{array}$ & $\begin{array}{l}8,4 \\
8,4\end{array}$ & $\begin{array}{l}5,7 \\
6,1\end{array}$ & $\begin{array}{l}0,65 \\
0,55\end{array}$ & $\begin{array}{l}39,2 \\
31,6\end{array}$ & $\begin{array}{l}2,2 \\
1,8\end{array}$ \\
\hline hrgila & 1 & $\begin{array}{l}A \\
B\end{array}$ & $\begin{array}{r}2 \\
10\end{array}$ & $\begin{array}{l}15 \\
19\end{array}$ & $\begin{array}{l}10,9 \\
16,0\end{array}$ & $\begin{array}{l}1,20 \\
0,82\end{array}$ & $\begin{array}{l}38,3 \\
17,8\end{array}$ & $\begin{array}{l}4,2 \\
2,9\end{array}$ \\
\hline ArgA/ArgB & & & 0,16 & 0,96 & 0,7 & 0,06 & 32,2 & 0,2 \\
\hline Silte/Argila & & $\begin{array}{l}A \\
B\end{array}$ & $\begin{array}{l}0,18 \\
0,17\end{array}$ & $\begin{array}{l}2,43 \\
0,57\end{array}$ & $\begin{array}{l}0,7 \\
0,4\end{array}$ & $\begin{array}{l}0,16 \\
0,03\end{array}$ & $\begin{array}{l}87,5 \\
32,3\end{array}$ & $\begin{array}{l}0,6 \\
0,1\end{array}$ \\
\hline$A B / A G$ & & $\begin{array}{l}A \\
B\end{array}$ & $\begin{array}{l}1,71 \\
4,82\end{array}$ & $\begin{array}{l}19,35 \\
38,10\end{array}$ & $\begin{array}{r}8,9 \\
18,5 \\
\end{array}$ & $\begin{array}{l}1,61 \\
2,61\end{array}$ & $\begin{array}{l}82,9 \\
52,6\end{array}$ & $\begin{array}{l}5,6 \\
9,8\end{array}$ \\
\hline
\end{tabular}


Resultados estatisticos de $\mathrm{pHCaCl}_{2}$ para as unidades de mapeamento de solos.

\begin{tabular}{|c|c|c|c|c|c|c|c|c|}
\hline $\begin{array}{l}\text { Voidades de } \\
\text { Kapeamento }\end{array}$ & Ho Amostras & $\begin{array}{l}\text { Prof. } \\
\text { (cII) }\end{array}$ & $\begin{array}{l}\text { Valor } \\
\text { Mínino } \\
\end{array}$ & $\begin{array}{l}\text { Valor } \\
\text { Mázino }\end{array}$ & Kédia & Erro Padrão & $\mathrm{Cl}$ & S \\
\hline LV & 8 & $\begin{array}{r}0-20 \\
60-80\end{array}$ & $\begin{array}{l}0,6 \\
5,1\end{array}$ & $\begin{array}{l}5,3 \\
6,5\end{array}$ & $\begin{array}{l}4,3 \\
5,9\end{array}$ & $\begin{array}{l}0,55 \\
0,24\end{array}$ & $\begin{array}{l}36,6 \\
10,0\end{array}$ & $\begin{array}{l}1,6 \\
0,6\end{array}$ \\
\hline LVp & 5 & $\begin{array}{r}0-20 \\
60-80\end{array}$ & $\begin{array}{l}4,2 \\
4,2\end{array}$ & $\begin{array}{l}5,2 \\
5,7\end{array}$ & $\begin{array}{l}4,6 \\
4,7\end{array}$ & $\begin{array}{l}0,21 \\
0,20\end{array}$ & $\begin{array}{l}10,4 \\
11,7\end{array}$ & $\begin{array}{l}0,5 \\
0,6\end{array}$ \\
\hline$P Y-2$ & 11 & $\begin{array}{r}0-20 \\
60-80\end{array}$ & $\begin{array}{l}4,9 \\
4,2\end{array}$ & $\begin{array}{l}6,3 \\
4,7\end{array}$ & $\begin{array}{l}5,4 \\
4,4\end{array}$ & $\begin{array}{l}0,11 \\
0,09\end{array}$ & $\begin{array}{l}7,3 \\
4,4\end{array}$ & $\begin{array}{l}0,4 \\
0,2\end{array}$ \\
\hline PV-3 & 6 & $\begin{array}{r}0-20 \\
60-80\end{array}$ & $\begin{array}{l}4,2 \\
4,8\end{array}$ & $\begin{array}{l}5,6 \\
5,6\end{array}$ & $\begin{array}{l}4,9 \\
5,2\end{array}$ & $\begin{array}{l}0,21 \\
0,10\end{array}$ & $\begin{array}{l}3,9 \\
7,9\end{array}$ & $\begin{array}{l}0,2 \\
0,4\end{array}$ \\
\hline PV -4 & 8 & $\begin{array}{r}0-20 \\
60-80\end{array}$ & $\begin{array}{l}4,5 \\
4,5\end{array}$ & $\begin{array}{l}5,0 \\
6,0\end{array}$ & $\begin{array}{l}4,9 \\
5,0\end{array}$ & $\begin{array}{l}0,07 \\
0,10\end{array}$ & $\begin{array}{r}10,6 \\
5,5\end{array}$ & $\begin{array}{l}0,5 \\
0,3\end{array}$ \\
\hline$P V-5$ & 14 & $\begin{array}{r}0-20 \\
60-80\end{array}$ & $\begin{array}{l}4,8 \\
4,7\end{array}$ & $\begin{array}{l}5,7 \\
5,1\end{array}$ & $\begin{array}{l}5,1 \\
4,9\end{array}$ & $\begin{array}{l}0,09 \\
0,10\end{array}$ & $\begin{array}{l}5,5 \\
3,3\end{array}$ & $\begin{array}{l}0,3 \\
0,2\end{array}$ \\
\hline$C$ & 8 & $\begin{array}{r}0-15 \\
15-30\end{array}$ & $\begin{array}{l}5,3 \\
4,8\end{array}$ & $\begin{array}{l}6,6 \\
6,3\end{array}$ & $\begin{array}{l}5,8 \\
5,8\end{array}$ & $\begin{array}{l}0,09 \\
0,10\end{array}$ & $\begin{array}{l}6,5 \\
6,9\end{array}$ & $\begin{array}{l}0,4 \\
0,1\end{array}$ \\
\hline R & 16 & $0-20$ & 5,3 & 6,6 & 5,7 & 0,09 & 6,5 & 0,4 \\
\hline
\end{tabular}


Resultados estatisticos do PHRCI das unidades de napeamento de solos.

\begin{tabular}{|c|c|c|c|c|c|c|c|c|}
\hline $\begin{array}{l}\text { Unidades de } \\
\text { Hapeanento }\end{array}$ & Ho hrostras & $\begin{array}{l}\text { Prof. } \\
\text { (cn) }\end{array}$ & $\begin{array}{l}\text { Valor } \\
\text { Minimo }\end{array}$ & $\begin{array}{l}\text { Valor } \\
\text { Kárino }\end{array}$ & Média & Brro Padrāo & $\mathrm{Cl}$ & $S$ \\
\hline LV & 8 & $\begin{array}{r}0-20 \\
60-80\end{array}$ & $\begin{array}{l}4,1 \\
4,1\end{array}$ & $\begin{array}{l}5,6 \\
5,8\end{array}$ & $\begin{array}{l}4,7 \\
4,6\end{array}$ & $\begin{array}{l}0,23 \\
0,21\end{array}$ & $\begin{array}{l}13,5 \\
13,2\end{array}$ & $\begin{array}{l}0,6 \\
0,6\end{array}$ \\
\hline LPp & 5 & $\begin{array}{r}0-20 \\
60-80\end{array}$ & $\begin{array}{l}4,1 \\
4,0\end{array}$ & $\begin{array}{l}5,1 \\
4,3\end{array}$ & $\begin{array}{l}4,5 \\
4,1\end{array}$ & $\begin{array}{l}0,21 \\
0,05\end{array}$ & $\begin{array}{r}10,3 \\
3,1\end{array}$ & $\begin{array}{l}0,6 \\
0,1\end{array}$ \\
\hline PV-2 & 8 & $\begin{array}{r}0-20 \\
60-80\end{array}$ & $\begin{array}{l}4,7 \\
4,2\end{array}$ & $\begin{array}{l}6,2 \\
6,6\end{array}$ & $\begin{array}{l}5,6 \\
5,1\end{array}$ & $\begin{array}{l}0,23 \\
0,23\end{array}$ & $\begin{array}{l}10,9 \\
14,9\end{array}$ & $\begin{array}{l}0,6 \\
0,8\end{array}$ \\
\hline$P V-3$ & 15 & $\begin{array}{r}0-20 \\
60-80\end{array}$ & $\begin{array}{l}4,8 \\
4,5\end{array}$ & $\begin{array}{l}7,4 \\
5,5\end{array}$ & $\begin{array}{l}5,7 \\
4,9\end{array}$ & $\begin{array}{l}0,19 \\
0,14\end{array}$ & $\begin{array}{r}13,4 \\
7,2\end{array}$ & $\begin{array}{l}0,8 \\
0,4\end{array}$ \\
\hline PY-4 & 6 & $\begin{array}{r}0-20 \\
60-80\end{array}$ & $\begin{array}{l}4,4 \\
4,6\end{array}$ & $\begin{array}{l}5,3 \\
7,0\end{array}$ & $\begin{array}{l}4,9 \\
5,1\end{array}$ & $\begin{array}{l}0,10 \\
0,29\end{array}$ & $\begin{array}{r}6,2 \\
16,0\end{array}$ & $\begin{array}{l}0,3 \\
0,8\end{array}$ \\
\hline$P V-5$ & 5 & $\begin{array}{r}0-20 \\
60-80\end{array}$ & $\begin{array}{l}4,4 \\
4,6\end{array}$ & $\begin{array}{l}6,0 \\
5,6\end{array}$ & $\begin{array}{l}5,2 \\
5,0\end{array}$ & $\begin{array}{l}0,15 \\
0,07\end{array}$ & $\begin{array}{r}10,0 \\
5,8\end{array}$ & $\begin{array}{l}0,5 \\
0,3\end{array}$ \\
\hline$c$ & & $\begin{array}{r}0-15 \\
15-30\end{array}$ & $\begin{array}{l}4,8 \\
4,9\end{array}$ & $\begin{array}{l}7,3 \\
5,8\end{array}$ & $\begin{array}{l}5,6 \\
5,3\end{array}$ & $\begin{array}{l}0,22 \\
0,14\end{array}$ & $\begin{array}{r}13,0 \\
6,0\end{array}$ & $\begin{array}{l}0,7 \\
0,3\end{array}$ \\
\hline 8 & 11 & $0-20$ & 4,8 & 7,3 & 5,6 & 0,22 & 13,0 & 0,7 \\
\hline
\end{tabular}


Resultados estatísticos jo $\mathrm{pH}$ en $\mathrm{H}_{2} \mathrm{O}$ das unidades de apeanento de solos.

\begin{tabular}{|c|c|c|c|c|c|c|c|c|}
\hline $\begin{array}{l}\text { Woidades de } \\
\text { Mapeamento }\end{array}$ & Ro Anostras & $\begin{array}{l}\text { Prof. } \\
\text { (cD) }\end{array}$ & $\begin{array}{l}\text { Valor } \\
\text { Kínimo }\end{array}$ & $\begin{array}{l}\text { Valor } \\
\text { Mári ino }\end{array}$ & Média & Erro Padrão & $\mathrm{CV}$ & $S$ \\
\hline LV & 8 & $\begin{array}{r}0-20 \\
60-80\end{array}$ & $\begin{array}{l}4,4 \\
4,1\end{array}$ & $\begin{array}{l}6,2 \\
6,4\end{array}$ & $\begin{array}{l}5,3 \\
4,9\end{array}$ & $\begin{array}{l}0,27 \\
0,27\end{array}$ & $\begin{array}{l}14,3 \\
15,7\end{array}$ & $\begin{array}{l}0,8 \\
0,8\end{array}$ \\
\hline Up & 5 & $\begin{array}{r}0-20 \\
60-80\end{array}$ & $\begin{array}{l}4,3 \\
4,2\end{array}$ & $\begin{array}{l}5,7 \\
4,7\end{array}$ & $\begin{array}{l}5,0 \\
4,5\end{array}$ & $\begin{array}{l}0,28 \\
0,08\end{array}$ & $\begin{array}{r}12,6 \\
4,3\end{array}$ & $\begin{array}{l}0,6 \\
0,2\end{array}$ \\
\hline$P V-2$ & 11 & $\begin{array}{r}0-20 \\
60-80\end{array}$ & $\begin{array}{l}4,9 \\
4,8\end{array}$ & $\begin{array}{l}7,4 \\
7,2\end{array}$ & $\begin{array}{l}5,9 \\
5,7\end{array}$ & $\begin{array}{l}0,19 \\
0,23\end{array}$ & $\begin{array}{l}11,0 \\
13,1\end{array}$ & $\begin{array}{l}0,7 \\
0,8\end{array}$ \\
\hline$P Y-3$ & 8 & $\begin{array}{r}0-20 \\
60-80\end{array}$ & $\begin{array}{l}5,3 \\
5,1\end{array}$ & $\begin{array}{l}6,5 \\
5,4\end{array}$ & $\begin{array}{l}5,8 \\
5,2\end{array}$ & $\begin{array}{l}0,20 \\
0,05\end{array}$ & $\begin{array}{l}8,6 \\
2,6\end{array}$ & $\begin{array}{l}0,5 \\
0,1\end{array}$ \\
\hline$P Y-4$ & 6 & $\begin{array}{r}0-20 \\
60-80\end{array}$ & $\begin{array}{l}5,1 \\
5,2\end{array}$ & $\begin{array}{l}5,9 \\
7,6\end{array}$ & $\begin{array}{l}5,5 \\
5,9\end{array}$ & $\begin{array}{l}0,09 \\
0,29\end{array}$ & $\begin{array}{r}4,9 \\
14,0\end{array}$ & $\begin{array}{l}0,3 \\
0,8\end{array}$ \\
\hline$P V-5$ & 15 & $\begin{array}{r}0-20 \\
60-80\end{array}$ & $\begin{array}{l}5,0 \\
5,2\end{array}$ & $\begin{array}{l}7,2 \\
6,2\end{array}$ & $\begin{array}{l}6,2 \\
5,6\end{array}$ & $\begin{array}{l}0,22 \\
0,07\end{array}$ & $\begin{array}{r}11,6 \\
5,2\end{array}$ & $\begin{array}{l}0,7 \\
0,3\end{array}$ \\
\hline$c$ & 5 & $\begin{array}{r}0-15 \\
15-30\end{array}$ & $\begin{array}{l}5,5 \\
5,5\end{array}$ & $\begin{array}{l}7,5 \\
6,4\end{array}$ & $\begin{array}{l}6,2 \\
6,0\end{array}$ & $\begin{array}{l}0,15 \\
0,15\end{array}$ & $\begin{array}{l}9,6 \\
5,8\end{array}$ & $\begin{array}{l}0,6 \\
0,4\end{array}$ \\
\hline$B$ & 16 & $0-20$ & 5,5 & 7,5 & 6,2 & 0,15 & 9,6 & 0,6 \\
\hline
\end{tabular}


Resultadios estatísticos do $\mathrm{dpH}$ das unidades de mapeamento de solo.

\begin{tabular}{|c|c|c|c|c|c|c|c|c|}
\hline $\begin{array}{l}\text { Unidades de } \\
\text { Mapeamento }\end{array}$ & Ho Amostras & $\begin{array}{l}\text { Prof. } \\
(\mathrm{cm})\end{array}$ & $\begin{array}{l}\text { Valor } \\
\text { Mĺnimo }\end{array}$ & $\begin{array}{l}\text { Valor } \\
\text { Mázimo }\end{array}$ & Média & Erro Padrão & $\mathrm{CV}$ & $\bar{S}$ \\
\hline$L V$ & 8 & $\begin{array}{r}0-20 \\
60-80\end{array}$ & $\begin{array}{l}-0,7 \\
-0,8\end{array}$ & $\begin{array}{l}-0,3 \\
0,0\end{array}$ & $\begin{array}{l}-0,6 \\
-0,3\end{array}$ & $\begin{array}{l}0,05 \\
0,09\end{array}$ & $\begin{array}{l}27,1 \\
82,1\end{array}$ & $\begin{array}{l}0,2 \\
0,3\end{array}$ \\
\hline WP & 5 & $\begin{array}{r}0-20 \\
60-80\end{array}$ & $\begin{array}{l}-0,8 \\
-0,7\end{array}$ & $\begin{array}{l}-0,1 \\
-0,2\end{array}$ & $\begin{array}{l}-0,5 \\
-0,4\end{array}$ & $\begin{array}{l}0,12 \\
0,09\end{array}$ & $\begin{array}{l}54,7 \\
57,6\end{array}$ & $\begin{array}{l}0,3 \\
0,2\end{array}$ \\
\hline$P V-2$ & 6 & $\begin{array}{r}0-20 \\
60-80\end{array}$ & $\begin{array}{l}-0,7 \\
-0,9\end{array}$ & $\begin{array}{l}0,0 \\
-0,3\end{array}$ & $\begin{array}{l}-0,5 \\
-0,6\end{array}$ & $\begin{array}{l}0,06 \\
0,05\end{array}$ & $\begin{array}{l}58,5 \\
27,8\end{array}$ & $\begin{array}{l}0,3 \\
0,2\end{array}$ \\
\hline$P Y-3$ & 16 & $\begin{array}{r}0-20 \\
60-80\end{array}$ & $\begin{array}{l}-0,9 \\
-0,6\end{array}$ & $\begin{array}{l}-0,1 \\
-0,6\end{array}$ & $\begin{array}{l}-0,5 \\
-0,3\end{array}$ & $\begin{array}{l}0,06 \\
0,11\end{array}$ & $\begin{array}{l}53,1 \\
84,1\end{array}$ & $\begin{array}{l}0,3 \\
0,3\end{array}$ \\
\hline$P Y-4$ & 8 & $\begin{array}{r}0-20 \\
60-80\end{array}$ & $\begin{array}{l}-0,9 \\
-1,3\end{array}$ & $\begin{array}{l}-0,3 \\
-0,6\end{array}$ & $\begin{array}{l}-0,6 \\
-0,9\end{array}$ & $\begin{array}{l}0,07 \\
0,09\end{array}$ & $\begin{array}{l}38,0 \\
30,9\end{array}$ & $\begin{array}{l}0,2 \\
0,3\end{array}$ \\
\hline$P Y-5$ & 11 & $\begin{array}{r}0-20 \\
60-80\end{array}$ & $\begin{array}{l}-1,3 \\
-0,8\end{array}$ & $\begin{array}{l}-0,5 \\
-0,3\end{array}$ & $\begin{array}{l}-0,9 \\
-0,6\end{array}$ & $\begin{array}{l}0,08 \\
0,03\end{array}$ & $\begin{array}{l}27,6 \\
23,6\end{array}$ & $\begin{array}{l}0,3 \\
0,1\end{array}$ \\
\hline C & 5 & $\begin{array}{r}0-15 \\
15-30\end{array}$ & $\begin{array}{l}-0,6 \\
-1,1\end{array}$ & $\begin{array}{c}0,0 \\
-0,3\end{array}$ & $\begin{array}{l}-0,3 \\
-0,7\end{array}$ & $\begin{array}{l}0,06 \\
0,14\end{array}$ & $\begin{array}{l}62,7 \\
46,9\end{array}$ & $\begin{array}{l}0,2 \\
0,3\end{array}$ \\
\hline $\mathbb{R}$ & 11 & $0-20$ & $-0,6$ & 0,0 & $-0,3$ & $-0,06$ & 62,7 & 0,2 \\
\hline
\end{tabular}


Resultados estatisticos da Acidez Trocável (Al ${ }^{3+}$ (meg/100 g) das unidades de mapeamento.

\begin{tabular}{|c|c|c|c|c|c|c|c|c|}
\hline $\begin{array}{l}\text { Onidades de } \\
\text { Mapeamento }\end{array}$ & Ro dmostras & $\begin{array}{l}\text { Prof. } \\
\text { (CB) }\end{array}$ & $\begin{array}{l}\text { Valor } \\
\text { MInimo }\end{array}$ & $\begin{array}{l}\text { Valor } \\
\text { Máxino }\end{array}$ & Média & Irro Padrāo & $\mathrm{CV}$ & $s$ \\
\hline IV & 8 & $\begin{array}{r}0-20 \\
60-80\end{array}$ & $\begin{array}{l}0,0 \\
0,0\end{array}$ & $\begin{array}{l}1,3 \\
1,4\end{array}$ & $\begin{array}{l}0,5 \\
0,6\end{array}$ & $\begin{array}{l}0,19 \\
0,21\end{array}$ & $\begin{array}{r}107,0 \\
97,0\end{array}$ & $\begin{array}{l}0,6 \\
0,6\end{array}$ \\
\hline LVp & 5 & $\begin{array}{r}0-20 \\
60-80\end{array}$ & $\begin{array}{l}0,0 \\
0,9\end{array}$ & $\begin{array}{l}1,1 \\
1,5\end{array}$ & $\begin{array}{l}0,6 \\
1,2\end{array}$ & $\begin{array}{l}0,22 \\
0,10\end{array}$ & $\begin{array}{l}88,8 \\
20,7\end{array}$ & $\begin{array}{l}0,5 \\
0,2\end{array}$ \\
\hline$P V-2$ & 6 & $\begin{array}{r}0-20 \\
60-80\end{array}$ & $\begin{array}{l}0,0 \\
0,0\end{array}$ & $\begin{array}{l}0,3 \\
0,9\end{array}$ & $\begin{array}{l}0,1 \\
0,2\end{array}$ & $\begin{array}{l}0,05 \\
0,08\end{array}$ & $\begin{array}{l}109,0 \\
182,0\end{array}$ & $\begin{array}{l}0,1 \\
0,3\end{array}$ \\
\hline PY-3 & 16 & $\begin{array}{r}0-20 \\
60-80\end{array}$ & $\begin{array}{l}0,0 \\
0,1\end{array}$ & $\begin{array}{l}0,1 \\
0,3\end{array}$ & $\begin{array}{l}0,0 \\
0,2\end{array}$ & $\begin{array}{l}0,01 \\
0,02\end{array}$ & $\begin{array}{r}132,0 \\
32,3\end{array}$ & $\begin{array}{l}0,0 \\
0,1\end{array}$ \\
\hline$P Y-4$ & 8 & $\begin{array}{r}0-20 \\
60-80\end{array}$ & $\begin{array}{l}0,0 \\
0,0\end{array}$ & $\begin{array}{l}0,1 \\
0,3\end{array}$ & $\begin{array}{l}0,1 \\
0,1\end{array}$ & $\begin{array}{l}0,01 \\
0,03\end{array}$ & $\begin{array}{l}45,4 \\
84,7\end{array}$ & $\begin{array}{l}0,0 \\
0,1\end{array}$ \\
\hline PY -5 & 11 & $\begin{array}{r}0-20 \\
60-80\end{array}$ & $\begin{array}{l}0,0 \\
0,0\end{array}$ & $\begin{array}{l}0,3 \\
0,3\end{array}$ & $\begin{array}{l}0,1 \\
0,1\end{array}$ & $\begin{array}{l}0,03 \\
0,02\end{array}$ & $\begin{array}{r}133,0 \\
70,3\end{array}$ & $\begin{array}{l}0,1 \\
0,1\end{array}$ \\
\hline c & 5 & $\begin{array}{r}0-15 \\
15-30\end{array}$ & $\begin{array}{l}0,0 \\
0,0\end{array}$ & $\begin{array}{l}0,1 \\
0,1\end{array}$ & $\begin{array}{l}0,0 \\
0,0\end{array}$ & $\begin{array}{l}0,01 \\
0,01\end{array}$ & $\begin{array}{r}232,0 \\
55,9\end{array}$ & $\begin{array}{l}0,0 \\
0,0\end{array}$ \\
\hline$R$ & 11 & $0-20$ & 0,0 & 0,1 & 0,0 & 0,01 & 232,0 & 0,1 \\
\hline
\end{tabular}


Resultados estatisticos de CTC/100g para as unidades de napeamento de solos.

\begin{tabular}{|c|c|c|c|c|c|c|c|c|}
\hline $\begin{array}{l}\text { Unidades de } \\
\text { Mapeamento }\end{array}$ & Ho Anostras & $\begin{array}{l}\text { Prof. } \\
\text { (cili) }\end{array}$ & $\begin{array}{l}\text { Valor } \\
\text { Kinimo }\end{array}$ & $\begin{array}{l}\text { Valor } \\
\text { Máximo }\end{array}$ & Hédia & Brro Padrão & $\mathrm{CV}$ & $s$ \\
\hline \multirow[t]{2}{*}{ LV } & \multirow[t]{2}{*}{8} & $0-20$ & 8,48 & 20,07 & 13,4 & 1,44 & 30,6 & 4,1 \\
\hline & & $60-80$ & $\ldots$ & $\ldots$ & $\ldots$ & $\ldots$ & $\ldots$ & $\ldots$ \\
\hline \multirow[t]{2}{*}{ LVp } & \multirow[t]{2}{*}{5} & $0-20$ & 4,52 & 21,65 & 14,2 & 2,77 & 43,7 & 4,1 \\
\hline & & $60-80$ & 9,13 & 21,51 & 14,2 & 1,43 & 28,5 & 55,9 \\
\hline \multirow[t]{2}{*}{$P V-2$} & \multirow[t]{2}{*}{11} & $0-20$ & 8,14 & 57,65 & 26,0 & 4,74 & 60,3 & 3,1 \\
\hline & & $60-80$ & 10,67 & 19,39 & 14,8 & 1,40 & 21,2 & 29,5 \\
\hline \multirow[t]{2}{*}{$P r-3$} & \multirow[t]{2}{*}{$\delta$} & $0-20$ & 10,07 & 25,12 & 19,7 & 2,22 & 27,7 & 17,3 \\
\hline & & $60-80$ & 18,39 & 68,20 & 38,3 & 6,10 & 45,1 & 122,4 \\
\hline \multirow[t]{2}{*}{ PV -4} & \multirow[t]{2}{*}{8} & $0-20$ & 12,45 & 92,90 & 44,0 & 10,44 & 67,1 & 4,9 \\
\hline & & $60-80$ & 7,06 & 25,25 & 11,4 & 1,49 & 43,2 & 5,4 \\
\hline \multirow[t]{2}{*}{ PV -5} & \multirow[t]{2}{*}{14} & $0-20$ & 27,13 & 454,09 & 116,7 & 38,71 & 104,9 & 2,1 \\
\hline & & $60-80$ & 10,03 & 15,99 & 12,8 & 0,86 & 16,5 & 55,9 \\
\hline \multirow[t]{2}{*}{$c$} & \multirow[t]{2}{*}{8} & $0-15$ & 37,29 & 257,38 & 148,7 & 14,00 & 37,5 & 146,7 \\
\hline & & $15-30$ & 31,29 & 595,66 & 205,1 & 42,36 & 71,6 & $\ldots$ \\
\hline$B$ & 16 & $0-20$ & 37,29 & 257,38 & 147,7 & 14,00 & 37,6 & 15,7 \\
\hline
\end{tabular}


Resultados estatisticos de 18 para as unidades de mapeamento de solos.

\begin{tabular}{|c|c|c|c|c|c|c|c|c|}
\hline $\begin{array}{l}\text { Unidades de } \\
\text { Mapeamento }\end{array}$ & Ko hmostras & $\begin{array}{l}\text { Prof. } \\
(\mathrm{cm})\end{array}$ & $\begin{array}{l}\text { ValoI } \\
\text { MInimo }\end{array}$ & $\begin{array}{l}\text { Valor } \\
\text { Máximo }\end{array}$ & Media & Brıo Padrão & $\mathrm{Cl}$ & $S$ \\
\hline$\overline{L V}$ & 8 & $\begin{array}{r}0-20 \\
60-80\end{array}$ & $\begin{array}{l}21 \\
82\end{array}$ & $\begin{array}{l}6 ! \\
96\end{array}$ & $\begin{array}{l}41,0 \\
90,8\end{array}$ & $\begin{array}{l}6,32 \\
2,17\end{array}$ & $\begin{array}{r}40,1 \\
5,8\end{array}$ & $\begin{array}{r}17,9 \\
5,3\end{array}$ \\
\hline LVP & 5 & $\begin{array}{r}0-20 \\
60-80\end{array}$ & $\begin{array}{l}24 \\
23\end{array}$ & $\begin{array}{l}62 \\
73\end{array}$ & $\begin{array}{l}40,0 \\
42,9\end{array}$ & $\begin{array}{l}7,93 \\
6,71\end{array}$ & $\begin{array}{l}44,1 \\
44,2\end{array}$ & $\begin{array}{l}17,7 \\
19,0\end{array}$ \\
\hline$P Y-2$ & 11 & $\begin{array}{r}0-20 \\
60-80\end{array}$ & $\begin{array}{l}46 \\
24\end{array}$ & $\begin{array}{l}93 \\
39\end{array}$ & $\begin{array}{l}65,0 \\
32,6\end{array}$ & $\begin{array}{l}3,70 \\
2,60\end{array}$ & $\begin{array}{l}18,8 \\
17,8\end{array}$ & $\begin{array}{r}12,3 \\
5,8\end{array}$ \\
\hline$P V-3$ & 6 & $\begin{array}{r}0-20 \\
60-80\end{array}$ & $\begin{array}{l}40 \\
59\end{array}$ & $\begin{array}{l}71 \\
80\end{array}$ & $\begin{array}{l}53,0 \\
68,5\end{array}$ & $\begin{array}{l}5,30 \\
2,38\end{array}$ & $\begin{array}{r}2 \$, 1 \\
9,8\end{array}$ & $\begin{array}{r}12,9 \\
6,7\end{array}$ \\
\hline$P V-4$ & 8 & $\begin{array}{r}0-20 \\
60-80\end{array}$ & $\begin{array}{l}35 \\
35\end{array}$ & $\begin{array}{l}59 \\
83\end{array}$ & $\begin{array}{l}52,0 \\
59,6\end{array}$ & $\begin{array}{l}2,80 \\
3,89\end{array}$ & $\begin{array}{l}15,1 \\
21,6\end{array}$ & $\begin{array}{r}7,9 \\
13,0\end{array}$ \\
\hline$P V-5$ & 14 & $\begin{array}{r}0-20 \\
60-80\end{array}$ & $\begin{array}{l}64 \\
52\end{array}$ & $\begin{array}{l}85 \\
62\end{array}$ & $\begin{array}{l}77,0 \\
57,0\end{array}$ & $\begin{array}{l}2,50 \\
1,60\end{array}$ & $\begin{array}{l}9,7 \\
6,8\end{array}$ & $\begin{array}{l}7,5 \\
3,9\end{array}$ \\
\hline C & 8 & $\begin{array}{r}0-15 \\
15-30\end{array}$ & $\begin{array}{l}77 \\
81\end{array}$ & $\begin{array}{l}96 \\
95\end{array}$ & $\begin{array}{l}87,0 \\
91,2\end{array}$ & $\begin{array}{l}1,56 \\
0,93\end{array}$ & $\begin{array}{l}7,1 \\
4,1\end{array}$ & $\begin{array}{l}6,2 \\
3,7\end{array}$ \\
\hline$R$ & 16 & $0-20$ & 77 & 96 & 87 & 1,56 & 7,1 & 6,2 \\
\hline
\end{tabular}


Resultados estatisticos de carbono orgånico $(8)$ para as unidades de mapeamento de solos.

\begin{tabular}{|c|c|c|c|c|c|c|c|c|}
\hline $\begin{array}{l}\text { Unidades de } \\
\text { Mapeamento }\end{array}$ & Ro Amostias & $\begin{array}{l}\text { Prof. } \\
\text { (ca) }\end{array}$ & $\begin{array}{l}\text { Valor } \\
\text { Minimo }\end{array}$ & $\begin{array}{l}\text { Valor } \\
\text { Máxino }\end{array}$ & Media & Brro Padrão & CV & $S$ \\
\hline LV & 8 & $\begin{array}{l}0-20 \\
60-80\end{array}$ & $\begin{array}{l}0,64 \\
0,52\end{array}$ & $\begin{array}{l}1,33 \\
2,09\end{array}$ & $\begin{array}{l}1,0 \\
1,4\end{array}$ & $\begin{array}{l}0,08 \\
0,19\end{array}$ & $\begin{array}{l}22,6 \\
38,4\end{array}$ & $\begin{array}{l}0,2 \\
0,5\end{array}$ \\
\hline LVp & 5 & $\begin{array}{r}0-20 \\
60-80\end{array}$ & $\begin{array}{l}0,64 \\
0,46\end{array}$ & $\begin{array}{l}0,99 \\
0,64\end{array}$ & $\begin{array}{l}0,8 \\
0,6\end{array}$ & $\begin{array}{l}0,07 \\
0,02\end{array}$ & $\begin{array}{l}21,5 \\
13,0\end{array}$ & $\begin{array}{l}0,2 \\
0,7\end{array}$ \\
\hline PY-2 & 11 & $\begin{array}{r}0-20 \\
60-80\end{array}$ & $\begin{array}{l}0,52 \\
0,46\end{array}$ & $\begin{array}{l}1,33 \\
0,52\end{array}$ & $\begin{array}{l}0,8 \\
0,5\end{array}$ & $\begin{array}{l}0,06 \\
0,01\end{array}$ & $\begin{array}{r}27,7 \\
6,8\end{array}$ & $\begin{array}{l}0,2 \\
0,0\end{array}$ \\
\hline PY -3 & 6 & $\begin{array}{r}0-20 \\
60-80\end{array}$ & $\begin{array}{l}0,52 \\
0,23\end{array}$ & $\begin{array}{l}0,93 \\
0,52\end{array}$ & $\begin{array}{l}0,6 \\
0,4\end{array}$ & $\begin{array}{l}0,06 \\
0,04\end{array}$ & $\begin{array}{l}25,3 \\
26,2\end{array}$ & $\begin{array}{l}0,2 \\
0,1\end{array}$ \\
\hline$P V-\&$ & 8 & $\begin{array}{r}0-20 \\
60-80\end{array}$ & $\begin{array}{l}0,52 \\
0,23\end{array}$ & $\begin{array}{l}1,16 \\
0,58\end{array}$ & $\begin{array}{l}0,9 \\
0,4\end{array}$ & $\begin{array}{l}0,07 \\
0,03\end{array}$ & $\begin{array}{l}21,2 \\
21,6\end{array}$ & $\begin{array}{l}0,2 \\
0,1\end{array}$ \\
\hline PV -5 & 14 & $\begin{array}{r}0-20 \\
60-80\end{array}$ & $\begin{array}{l}0,99 \\
0,35\end{array}$ & $\begin{array}{l}1,91 \\
0,58\end{array}$ & $\begin{array}{l}1,5 \\
0,4\end{array}$ & $\begin{array}{l}0,09 \\
0,03\end{array}$ & $\begin{array}{l}18,6 \\
17,5\end{array}$ & $\begin{array}{l}0,3 \\
0,1\end{array}$ \\
\hline c & 8 & $\begin{array}{r}0-15 \\
15-30\end{array}$ & $\begin{array}{l}0,35 \\
0,17\end{array}$ & $\begin{array}{l}2,78 \\
1,04\end{array}$ & $\begin{array}{l}1,7 \\
0,5\end{array}$ & $\begin{array}{l}0,15 \\
0,06\end{array}$ & $\begin{array}{l}35,6 \\
47,6\end{array}$ & $\begin{array}{l}0,6 \\
0,2\end{array}$ \\
\hline$R$ & 16 & $0-20$ & 0,35 & 2,78 & 1,7 & 0,15 & 35,6 & 0,6 \\
\hline
\end{tabular}


Resultados estatísticos de crc/100g para as unidades de napeamento de solos.

\begin{tabular}{|c|c|c|c|c|c|c|c|c|}
\hline $\begin{array}{l}\text { Unidades de } \\
\text { Mapeamento }\end{array}$ & Ho Amostras & $\begin{array}{l}\text { Prof. } \\
\text { (ca) }\end{array}$ & $\begin{array}{l}\text { Valor } \\
\text { Mínimo }\end{array}$ & $\begin{array}{l}\text { Valor } \\
\text { Máxino }\end{array}$ & Media & Erro Padiāo & $\mathrm{Cl}$ & s \\
\hline WV & 8 & $\begin{array}{l}0-20 \\
60-80\end{array}$ & $\begin{array}{r}8,48 \\
84,99\end{array}$ & $\begin{array}{c}20,07 \\
331,59\end{array}$ & $\begin{array}{r}13,4 \\
157,3\end{array}$ & $\begin{array}{r}1,44 \\
27,15\end{array}$ & $\begin{array}{l}30,6 \\
48,8\end{array}$ & $\begin{array}{r}4,1 \\
19,0\end{array}$ \\
\hline LVP & 5 & $\begin{array}{r}0-20 \\
60-80\end{array}$ & $\begin{array}{l}4,52 \\
9,13\end{array}$ & $\begin{array}{l}21,65 \\
21,51\end{array}$ & $\begin{array}{l}14,2 \\
14,2\end{array}$ & $\begin{array}{l}2,77 \\
1,43\end{array}$ & $\begin{array}{l}43,7 \\
28,5\end{array}$ & $\begin{array}{r}4,1 \\
55,9\end{array}$ \\
\hline$P V-2$ & 11 & $\begin{array}{r}0-20 \\
60-80\end{array}$ & $\begin{array}{r}8,14 \\
10,67\end{array}$ & $\begin{array}{l}57,65 \\
19,39\end{array}$ & $\begin{array}{l}26,0 \\
14,8\end{array}$ & $\begin{array}{l}4,74 \\
1,40\end{array}$ & $\begin{array}{l}60,3 \\
21,2\end{array}$ & $\begin{array}{r}3,1 \\
29,5\end{array}$ \\
\hline$P V-3$ & 6 & $\begin{array}{r}0-20 \\
60-80\end{array}$ & $\begin{array}{l}10,07 \\
18,39\end{array}$ & $\begin{array}{l}25,12 \\
68,20\end{array}$ & $\begin{array}{l}19,7 \\
38,3\end{array}$ & $\begin{array}{l}2,22 \\
6,10\end{array}$ & $\begin{array}{l}27,7 \\
45,1\end{array}$ & $\begin{array}{r}17,3 \\
122,4\end{array}$ \\
\hline$P V-4$ & 8 & $\begin{array}{r}0-20 \\
60-80\end{array}$ & $\begin{array}{r}12,45 \\
7,06\end{array}$ & $\begin{array}{l}92,90 \\
25,25\end{array}$ & $\begin{array}{l}44,0 \\
11,4\end{array}$ & $\begin{array}{r}10,44 \\
1,49\end{array}$ & $\begin{array}{l}67,1 \\
43,2\end{array}$ & $\begin{array}{l}4,9 \\
5,4\end{array}$ \\
\hline$P V-5$ & 14 & $\begin{array}{r}0-20 \\
60-80\end{array}$ & $\begin{array}{l}27,13 \\
10,03\end{array}$ & $\begin{array}{l}454,09 \\
15,99\end{array}$ & $\begin{array}{r}116,7 \\
12,8\end{array}$ & $\begin{array}{r}38,71 \\
0,86\end{array}$ & $\begin{array}{r}104,9 \\
16,5\end{array}$ & $\begin{array}{r}2,1 \\
55,9\end{array}$ \\
\hline c & 8 & $\begin{array}{r}0-15 \\
15-30\end{array}$ & $\begin{array}{l}37,29 \\
31,29\end{array}$ & $\begin{array}{l}257,38 \\
595,66\end{array}$ & $\begin{array}{l}148,7 \\
205,1\end{array}$ & $\begin{array}{l}14,00 \\
42,36\end{array}$ & $\begin{array}{l}37,5 \\
71,6\end{array}$ & $\begin{array}{c}146,7 \\
\ldots\end{array}$ \\
\hline 8 & 16 & $0-20$ & 37,29 & 257,38 & 147,7 & 14,00 & 37,6 & 15,7 \\
\hline
\end{tabular}


Resultados estatisticos da $f$ argila para as unidades de mapeamento dos solos.

\begin{tabular}{|c|c|c|c|c|c|c|c|c|}
\hline $\begin{array}{l}\text { Unidades de } \\
\text { Hapeamento }\end{array}$ & Ho Amostras & $\begin{array}{l}\text { Prof. } \\
\text { (cmil }\end{array}$ & $\begin{array}{l}\text { Valor } \\
\text { Kínino }\end{array}$ & $\begin{array}{l}\text { Valor } \\
\text { Máxino }\end{array}$ & Média & Erro Padrão & $\mathrm{Cl}$ & S \\
\hline UI & 8 & $\begin{array}{l}0-20 \\
60-80\end{array}$ & $\begin{array}{l}13 \\
24\end{array}$ & $\begin{array}{l}25 \\
34\end{array}$ & $\begin{array}{l}20,3 \\
29,5\end{array}$ & $\begin{array}{l}1,42 \\
1,47\end{array}$ & $\begin{array}{l}19,8 \\
14,1\end{array}$ & $\begin{array}{l}4,0 \\
4,2\end{array}$ \\
\hline Wp & 5 & $\begin{array}{r}0-20 \\
60-80\end{array}$ & $\begin{array}{l}14 \\
23\end{array}$ & $\begin{array}{l}26 \\
36\end{array}$ & $\begin{array}{l}17,9 \\
31,1\end{array}$ & $\begin{array}{l}2,11 \\
2,18\end{array}$ & $\begin{array}{l}26,8 \\
15,6\end{array}$ & $\begin{array}{l}4,8 \\
4,9\end{array}$ \\
\hline$P V-2$ & 11 & $\begin{array}{r}0-20 \\
60-80\end{array}$ & $\begin{array}{r}3 \\
11\end{array}$ & $\begin{array}{l}40 \\
45\end{array}$ & $\begin{array}{l}14,4 \\
34,6\end{array}$ & $\begin{array}{l}2,96 \\
2,88\end{array}$ & $\begin{array}{l}67,8 \\
27,5\end{array}$ & $\begin{array}{l}9,8 \\
9,6\end{array}$ \\
\hline$P V-3$ & 6 & $\begin{array}{r}0-20 \\
60-80\end{array}$ & $\begin{array}{c}9 \\
32\end{array}$ & $\begin{array}{l}13 \\
40\end{array}$ & $\begin{array}{l}12,4 \\
37,4\end{array}$ & $\begin{array}{l}0,70 \\
1,36\end{array}$ & $\begin{array}{r}13,8 \\
8,9\end{array}$ & $\begin{array}{l}1,7 \\
3,3\end{array}$ \\
\hline$P V-4$ & 8 & $\begin{array}{l}0-20 \\
60-80\end{array}$ & $\begin{array}{r}1 \\
13\end{array}$ & $\begin{array}{l}15 \\
26\end{array}$ & $\begin{array}{c}6,2 \\
19,9\end{array}$ & $\begin{array}{l}1,98 \\
1,81\end{array}$ & $\begin{array}{l}30,5 \\
25,7\end{array}$ & $\begin{array}{l}5,6 \\
5,1\end{array}$ \\
\hline$P V-5$ & 14 & $\begin{array}{r}0-20 \\
60-80\end{array}$ & $\begin{array}{l}2 \\
2\end{array}$ & $\begin{array}{l}40 \\
36\end{array}$ & $\begin{array}{c}16,8 \\
11,19\end{array}$ & $\begin{array}{l}2,52 \\
2,08\end{array}$ & $\begin{array}{l}55,9 \\
71,9\end{array}$ & $\begin{array}{l}9,4 \\
8,1\end{array}$ \\
\hline$c$ & 8 & $\begin{array}{r}0-15 \\
15-30\end{array}$ & $\begin{array}{l}2 \\
7\end{array}$ & $\begin{array}{l}20 \\
15\end{array}$ & $\begin{array}{l}9,6 \\
11,4\end{array}$ & $\begin{array}{l}1,43 \\
0,99\end{array}$ & $\begin{array}{l}57,8 \\
24,4\end{array}$ & $\begin{array}{l}5,6 \\
2,8\end{array}$ \\
\hline$R$ & 16 & $0-20$ & 2 & 20 & 9,6 & 1,43 & 25,8 & 5,6 \\
\hline
\end{tabular}


Resultados estatísticos de silte para as unidades de mapeanento de solos.

\begin{tabular}{|c|c|c|c|c|c|c|c|c|}
\hline $\begin{array}{l}\text { Tnidades de } \\
\text { Mapeamento }\end{array}$ & Ho dRostras & $\begin{array}{l}\text { Prof. } \\
\text { (CR) }\end{array}$ & $\begin{array}{l}\text { Valor } \\
\text { Mínino }\end{array}$ & $\begin{array}{l}\text { Valor } \\
\text { Mázino }\end{array}$ & Média & Erro Padrão & $\mathrm{CV}$ & $S$ \\
\hline Ir & 8 & $\begin{array}{l}0-20 \\
60-80\end{array}$ & $\begin{array}{l}0,3 \\
0,6\end{array}$ & $\begin{array}{l}3,2 \\
2,1\end{array}$ & $\begin{array}{l}1,2 \\
1,2\end{array}$ & $\begin{array}{l}0,29 \\
0,17\end{array}$ & $\begin{array}{l}70,4 \\
42,1\end{array}$ & $\begin{array}{l}0,8 \\
0,5\end{array}$ \\
\hline LVIP & 5 & $\begin{array}{l}0-20 \\
60-80\end{array}$ & $\begin{array}{l}0,9 \\
0,8\end{array}$ & $\begin{array}{l}3,3 \\
1,3\end{array}$ & $\begin{array}{l}1,9 \\
1,0\end{array}$ & $\begin{array}{l}0,55 \\
0,07\end{array}$ & $\begin{array}{l}60,5 \\
15,9\end{array}$ & $\begin{array}{l}1,3 \\
0,2\end{array}$ \\
\hline$P V-2$ & 11 & $\begin{array}{l}0-20 \\
60-80\end{array}$ & $\begin{array}{l}0,4 \\
0,3\end{array}$ & $\begin{array}{l}6,9 \\
6,9\end{array}$ & $\begin{array}{l}2,9 \\
3,0\end{array}$ & $\begin{array}{l}0,65 \\
0,59\end{array}$ & $\begin{array}{l}34,6 \\
65,1\end{array}$ & $\begin{array}{l}2,2 \\
2,0\end{array}$ \\
\hline$P V-3$ & 6 & $\begin{array}{r}0-20 \\
60-80\end{array}$ & $\begin{array}{l}0,4 \\
0,9\end{array}$ & $\begin{array}{l}3,9 \\
4,8\end{array}$ & $\begin{array}{l}2,0 \\
2,0\end{array}$ & $\begin{array}{l}0,50 \\
0,60\end{array}$ & $\begin{array}{l}63,7 \\
73,9\end{array}$ & $\begin{array}{l}1,2 \\
0,6\end{array}$ \\
\hline$P V-4$ & 8 & $\begin{array}{r}0-20 \\
60-80\end{array}$ & $\begin{array}{l}0,5 \\
1,0\end{array}$ & $\begin{array}{l}6,3 \\
4,8\end{array}$ & $\begin{array}{l}3,4 \\
2,6\end{array}$ & $\begin{array}{l}0,63 \\
0,47\end{array}$ & $\begin{array}{l}53,8 \\
51,9\end{array}$ & $\begin{array}{l}1,8 \\
1,3\end{array}$ \\
\hline$P Y-5$ & 14 & $\begin{array}{l}0-20 \\
60-80\end{array}$ & $\begin{array}{l}0,8 \\
0,8\end{array}$ & $\begin{array}{l}8,4 \\
8,5\end{array}$ & $\begin{array}{l}5,2 \\
4,8\end{array}$ & $\begin{array}{l}0,81 \\
0,71\end{array}$ & $\begin{array}{l}53,7 \\
57,9\end{array}$ & $\begin{array}{l}3,1 \\
2,8\end{array}$ \\
\hline$c$ & 8 & $\begin{array}{r}0-15 \\
15-30\end{array}$ & $\begin{array}{l}3,0 \\
2,9\end{array}$ & $\begin{array}{l}9,8 \\
7,1\end{array}$ & $\begin{array}{l}5,5 \\
5,6\end{array}$ & $\begin{array}{l}0,49 \\
0,60\end{array}$ & $\begin{array}{l}34,6 \\
30,9\end{array}$ & $\begin{array}{l}1,9 \\
1,7\end{array}$ \\
\hline 8 & 16 & $0-20$ & 3,0 & 9,8 & 5,5 & 0,49 & 34,6 & 1,9 \\
\hline
\end{tabular}


Resultados estatísticos da relação silte/argila para as unidades de mapeamento de solos.

\begin{tabular}{|c|c|c|c|c|c|c|c|c|}
\hline $\begin{array}{l}\text { Unidades de } \\
\text { Kapeamento }\end{array}$ & Ho Amostras & $\begin{array}{l}\text { Prof. } \\
\text { (cri) }\end{array}$ & $\begin{array}{l}\text { Valor } \\
\text { Mínino }\end{array}$ & $\begin{array}{l}\text { Valor } \\
\text { Mázimo }\end{array}$ & Hédia & Erro Padrão & $\mathrm{CV}$ & $S$ \\
\hline IV & 8 & $\begin{array}{l}0-20 \\
60-80\end{array}$ & $\begin{array}{l}0,02 \\
0,02\end{array}$ & $\begin{array}{l}0,24 \\
0,08\end{array}$ & $\begin{array}{l}0,06 \\
0,04\end{array}$ & $\begin{array}{l}0,02 \\
0,00\end{array}$ & $\begin{array}{r}104,6 \\
26,1\end{array}$ & $\begin{array}{l}0,07 \\
0,02\end{array}$ \\
\hline LVp & 5 & $\begin{array}{r}0-20 \\
60-80\end{array}$ & $\begin{array}{l}0,01 \\
0,02\end{array}$ & $\begin{array}{l}0,23 \\
0,04\end{array}$ & $\begin{array}{l}0,12 \\
0,03\end{array}$ & $\begin{array}{l}0,04 \\
0,00\end{array}$ & $\begin{array}{l}80,1 \\
65,0\end{array}$ & $\begin{array}{l}0,09 \\
0,00\end{array}$ \\
\hline$P Y-2$ & 11 & $\begin{array}{r}0-20 \\
60-80\end{array}$ & $\begin{array}{l}0,03 \\
0,01\end{array}$ & $\begin{array}{l}2,42 \\
0,20\end{array}$ & $\begin{array}{l}0,42 \\
0,09\end{array}$ & $\begin{array}{l}0,21 \\
0,01\end{array}$ & $\begin{array}{r}164,5 \\
65,0\end{array}$ & $\begin{array}{l}0,69 \\
0,06\end{array}$ \\
\hline$P V-3$ & 6 & $\begin{array}{r}0-20 \\
60-80\end{array}$ & $\begin{array}{l}0,05 \\
0,12\end{array}$ & $\begin{array}{l}0,28 \\
0,14\end{array}$ & $\begin{array}{l}0,15 \\
0,05\end{array}$ & $\begin{array}{l}0,03 \\
0,01\end{array}$ & $\begin{array}{l}57,2 \\
80,9\end{array}$ & $\begin{array}{l}0,08 \\
0,04\end{array}$ \\
\hline$P V-4$ & 8 & $\begin{array}{r}0-20 \\
60-80\end{array}$ & $\begin{array}{l}0,08 \\
0,04\end{array}$ & $\begin{array}{l}1,55 \\
0,20\end{array}$ & $\begin{array}{l}0,66 \\
0,14\end{array}$ & $\begin{array}{l}0,17 \\
0,03\end{array}$ & $\begin{array}{l}74,7 \\
64,3\end{array}$ & $\begin{array}{l}0,49 \\
0,09\end{array}$ \\
\hline$P V-5$ & 14 & $\begin{array}{r}0-20 \\
60-80\end{array}$ & $\begin{array}{l}0,02 \\
0,03\end{array}$ & $\begin{array}{l}0,78 \\
2,4\end{array}$ & $\begin{array}{l}0,36 \\
0,57\end{array}$ & $\begin{array}{l}0,05 \\
0,14\end{array}$ & $\begin{array}{l}55,1 \\
94,7\end{array}$ & $\begin{array}{l}0,20 \\
0,54\end{array}$ \\
\hline C & 8 & $\begin{array}{r}0-15 \\
15-30\end{array}$ & $\begin{array}{l}0,20 \\
0,21\end{array}$ & $\begin{array}{l}1,44 \\
0,88\end{array}$ & $\begin{array}{l}0,77 \\
0,51\end{array}$ & $\begin{array}{l}0,10 \\
0,07\end{array}$ & $\begin{array}{l}52,7 \\
42,2\end{array}$ & $\begin{array}{l}0,40 \\
0,20\end{array}$ \\
\hline 8 & 15 & $0-20$ & 0,20 & 1,44 & 0,77 & 0,10 & 52,7 & 0,40 \\
\hline
\end{tabular}


Resultados estatísticos da Areia Pina/Areia Grossa para as unidades de mapeamento dos solos.

\begin{tabular}{|c|c|c|c|c|c|c|c|c|}
\hline $\begin{array}{l}\text { Vnidades de } \\
\text { Mapeamento }\end{array}$ & RO Anostras & $\begin{array}{l}\text { Prof. } \\
\text { (cm) }\end{array}$ & $\begin{array}{l}\text { Valor } \\
\text { Minimo }\end{array}$ & $\begin{array}{l}\text { Palor } \\
\text { Máximo }\end{array}$ & Hedia & Brro Padrão & $\mathrm{CV}$ & $S$ \\
\hline \multirow[t]{2}{*}{ WV } & \multirow[t]{2}{*}{8} & $0-20$ & 8,0 & 13,5 & 11,0 & 0,65 & 17,0 & 1,8 \\
\hline & & $60-80$ & 9,8 & 18,9 & 13,2 & 0,95 & 20,3 & 2,6 \\
\hline \multirow[t]{2}{*}{ Lip } & \multirow[t]{2}{*}{5} & $0-20$ & 2,9 & 12,8 & 6,8 & 1,83 & 60,3 & 4,0 \\
\hline & & $60-80$ & 4,3 & 8,4 & 5,6 & 0,75 & 30,8 & 1,6 \\
\hline \multirow[t]{2}{*}{$\mathrm{PV}-2$} & \multirow[t]{2}{*}{11} & $0-20$ & 2,2 & 6,1 & 4,1 & 0,48 & 32,7 & 1,3 \\
\hline & & $60-80$ & 2,4 & 5,4 & 3,5 & 0,29 & 27,9 & 0,9 \\
\hline \multirow[t]{2}{*}{ PY -3} & \multirow[t]{2}{*}{6} & $0-20$ & 5,1 & 12,1 & 7,9 & 1,17 & 31,0 & 2,8 \\
\hline & & $60-80$ & 3,5 & 7,6 & 5,8 & 0,71 & 30,0 & 1,7 \\
\hline \multirow[t]{2}{*}{$P V-4$} & \multirow[t]{2}{*}{8} & $0-20$ & 4,1 & 9,9 & 6,8 & 0,74 & 31,0 & 2,1 \\
\hline & & $60-80$ & 5,3 & 11,5 & 8,0 & 0,76 & 26,8 & 2,1 \\
\hline \multirow[t]{2}{*}{$P V-5$} & \multirow[t]{2}{*}{14} & $0-20$ & 4,6 & 33,1 & 14,5 & 2,90 & 36,4 & 10,0 \\
\hline & & $60-80$ & 4,2 & 41,4 & 16,0 & 2,93 & 70,8 & 11,3 \\
\hline \multirow[t]{2}{*}{$c$} & \multirow[t]{2}{*}{8} & $0-15$ & 5,80 & 64,8 & 25,8 & 4,40 & 66,4 & 17,1 \\
\hline & & $15-30$ & 5,33 & 39,2 & 19,3 & 3,94 & 57,8 & 11,1 \\
\hline R & 16 & $0-20$ & 5,8 & 64,8 & 25,8 & 4,40 & 66,4 & 17,1 \\
\hline
\end{tabular}


A P E N D ICE 4

DESCRIÇÃO SUMÁRIA DA MICROMOFORLOGIA DOS SOLOS ESTUDADOS 
Avaliação qualitativa de feiçōes micromorfológicas dos perfis da transeção e suas posições na vertente (Amostras do horizonte B dos solos).

\begin{tabular}{|c|c|c|c|c|}
\hline Solos & GIãos & Trama & Plasma & Peições \\
\hline LV & $\begin{array}{l}\text { Quartzo modera- } \\
\text { damente sele- } \\
\text { cionado }\end{array}$ & $\begin{array}{l}\text { Gefúrica, } \\
\text { localmente } \\
\text { porfírica }\end{array}$ & $\begin{array}{l}\text { Isótico, bruno- } \\
\text { avernel hado }\end{array}$ & $\begin{array}{l}\text { Nódulos de trama por } \\
\text { firica, presença de } \\
\text { nódulos ferruginoso; } \\
\text { Pedotubulos conuns }\end{array}$ \\
\hline LV & $\begin{array}{l}\text { Quartzo arre- } \\
\text { dondado a su- } \\
\text { barredondado, } \\
\text { presença de } \\
\text { microlina }\end{array}$ & $\begin{array}{l}\text { Gefúrica, } \\
\text { localmente } \\
\text { porfírica }\end{array}$ & $\begin{array}{l}\text { isótico, bruno- } \\
\text { avermelhado }\end{array}$ & $\begin{array}{l}\text { Pedotubulos preenchi } \\
\text { dos com matriz porfi } \\
\text { rica, nódulos ferru- } \\
\text { ginosos }\end{array}$ \\
\hline$P Y-2$ & $\begin{array}{l}\text { Quartzo modera- } \\
\text { damente sele- } \\
\text { cionado, pre- } \\
\text { sença feldspato }\end{array}$ & $\begin{array}{l}\text { Gefúrica, con } \\
\text { microagrega- } \\
\text { dos isolados }\end{array}$ & $\begin{array}{l}\text { Massépico con } \\
\text { tendência isó- } \\
\text { tico }\end{array}$ & $\begin{array}{l}\text { Nódulos de trama por } \\
\text { firica, com ausência } \\
\text { de nodulos ferrugino } \\
\text { sos, poucos cutãs de } \\
\text { iluviação }\end{array}$ \\
\hline$P V-3$ & $\begin{array}{l}\text { Quartio modera- } \\
\text { damente a pouco } \\
\text { selecionado }\end{array}$ & Porfírica & $\begin{array}{l}\text { Massépico, } \\
\text { localnente } \\
\text { vossépico }\end{array}$ & $\begin{array}{l}\text { Rerriargilãs de } \\
\text { iluviação recobrindo } \\
\text { cavidades e poros }\end{array}$ \\
\hline$P Y-4$ & $\begin{array}{l}\text { Quartzo, com } \\
\text { presença comum } \\
\text { de fd. (Integros } \\
\text { e careados); } \\
\text { turmalina, zir- } \\
\text { cão, mica }\end{array}$ & Porfírica & Massépico & $\begin{array}{l}\text { Perrans en torno de } \\
\text { cavidades em posição } \\
\text { cutânica a } \\
\text { subcutânica }\end{array}$ \\
\hline$c$ & $\begin{array}{l}\text { Quartzo, cora } \\
\text { presença de } \\
\text { feldspato, } \\
\text { mica, zirção e } \\
\text { rutilo }\end{array}$ & $\begin{array}{l}\text { Porfirica } \\
\text { aberta }\end{array}$ & $\begin{array}{l}\text { ¿squelromassé- } \\
\text { pica }\end{array}$ & $\begin{array}{l}\text { Rerrans en torno de } \\
\text { cavidades en posição } \\
\text { cutânica a } \\
\text { subcutânica }\end{array}$ \\
\hline B & $\begin{array}{l}\text { Quartzo, con } \\
\text { presença de } \\
\text { feldspato, } \\
\text { turmalina, mica }\end{array}$ & $\begin{array}{l}\text { Gefúrica, } \\
\text { localmente } \\
\text { porfirica }\end{array}$ & $\begin{array}{l}\text { Insépico, bruno } \\
\text { avermelhado } \\
\text { escuro }\end{array}$ & $\begin{array}{l}\text { Perrans en torno de } \\
\text { cavidades en posição } \\
\text { cutånica a } \\
\text { subcutânica }\end{array}$ \\
\hline
\end{tabular}




\section{A P E N D I CE 5}

DIFRATOGRAMAS DE RAIOS X E TERMOGRAMAS DA FRAÇÃO ARGILA TRATADA COM DCB DOS SOLOS ESTUDADOS 


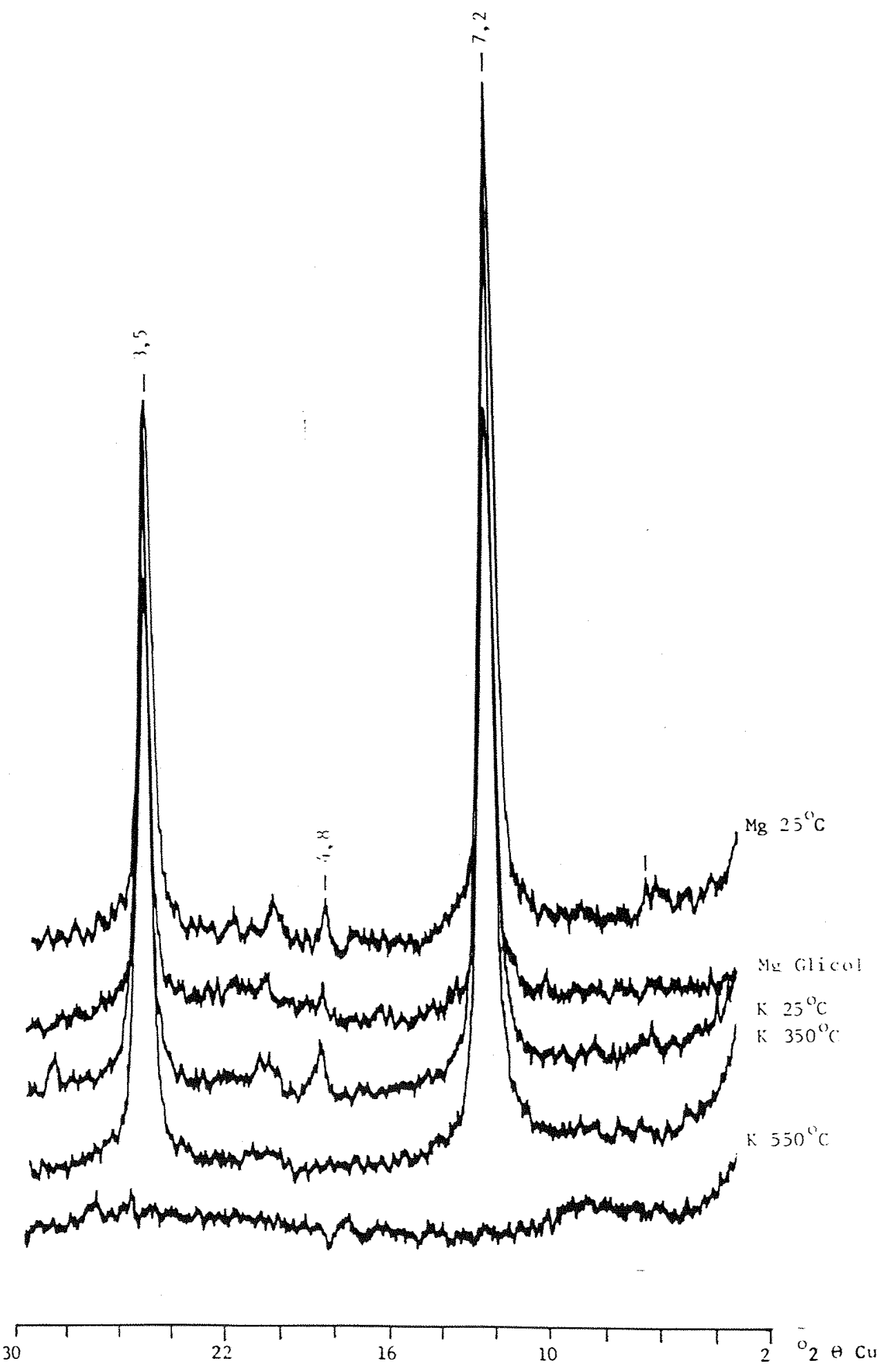

Difratogramas da fração argila do horizonte Ap - IV (Perfil 1) 


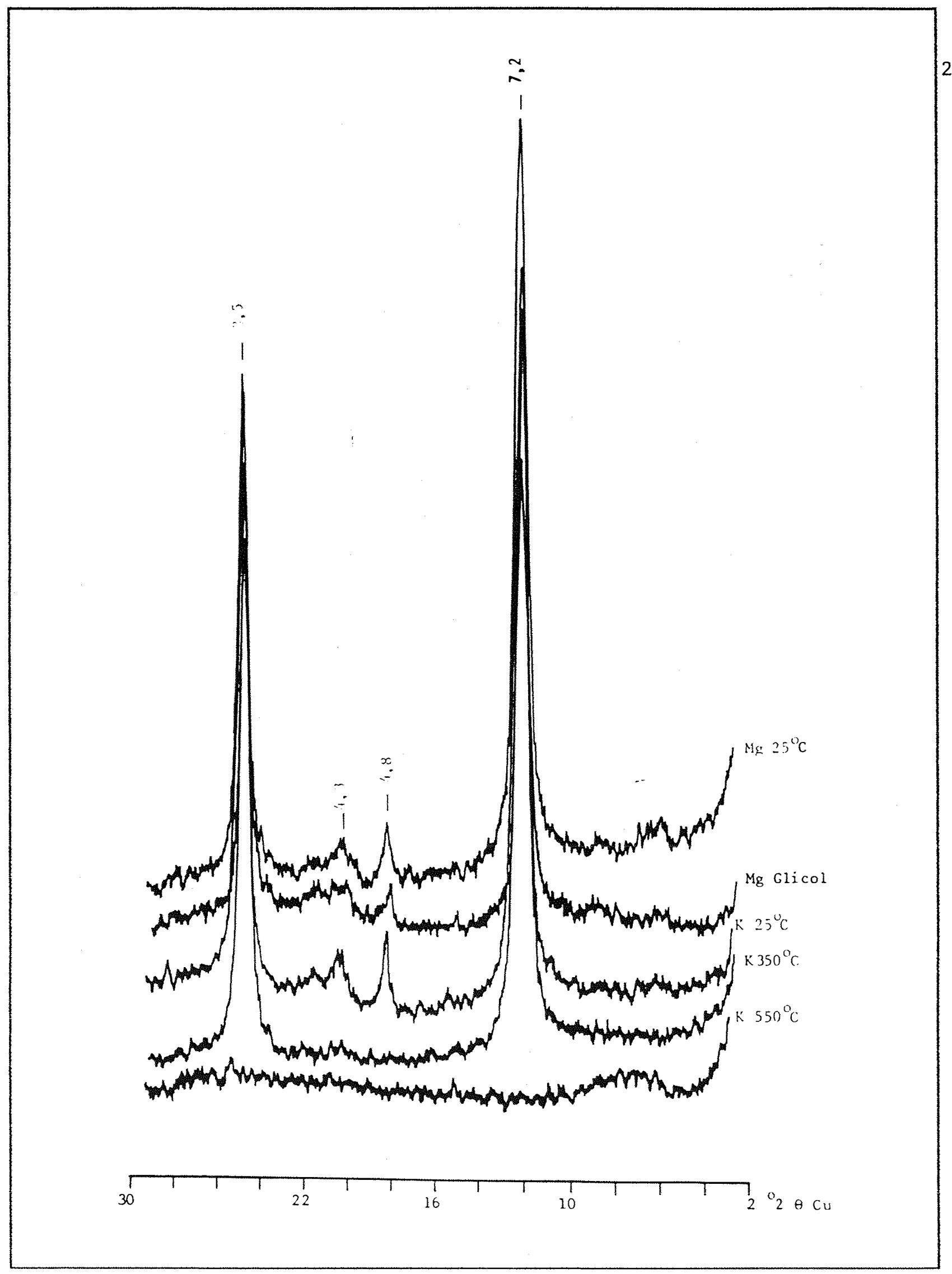

Difratogramas da fração argila do horizonte $\mathrm{BW}_{2}-\mathrm{LV}$ (Perfil 1) 


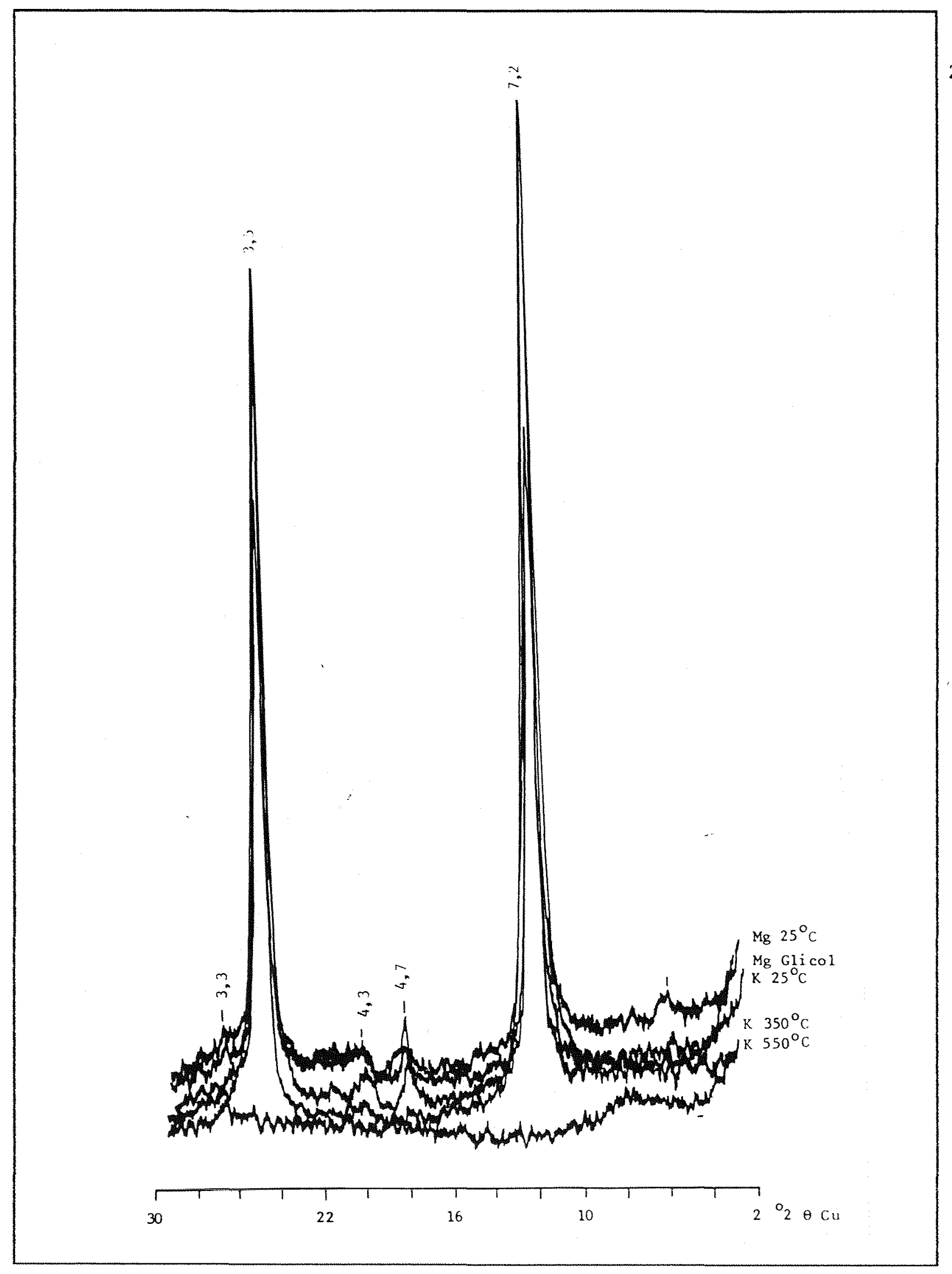

Difratogramas da fração argila do horizonte Ap - LVp (Perfil 2) 


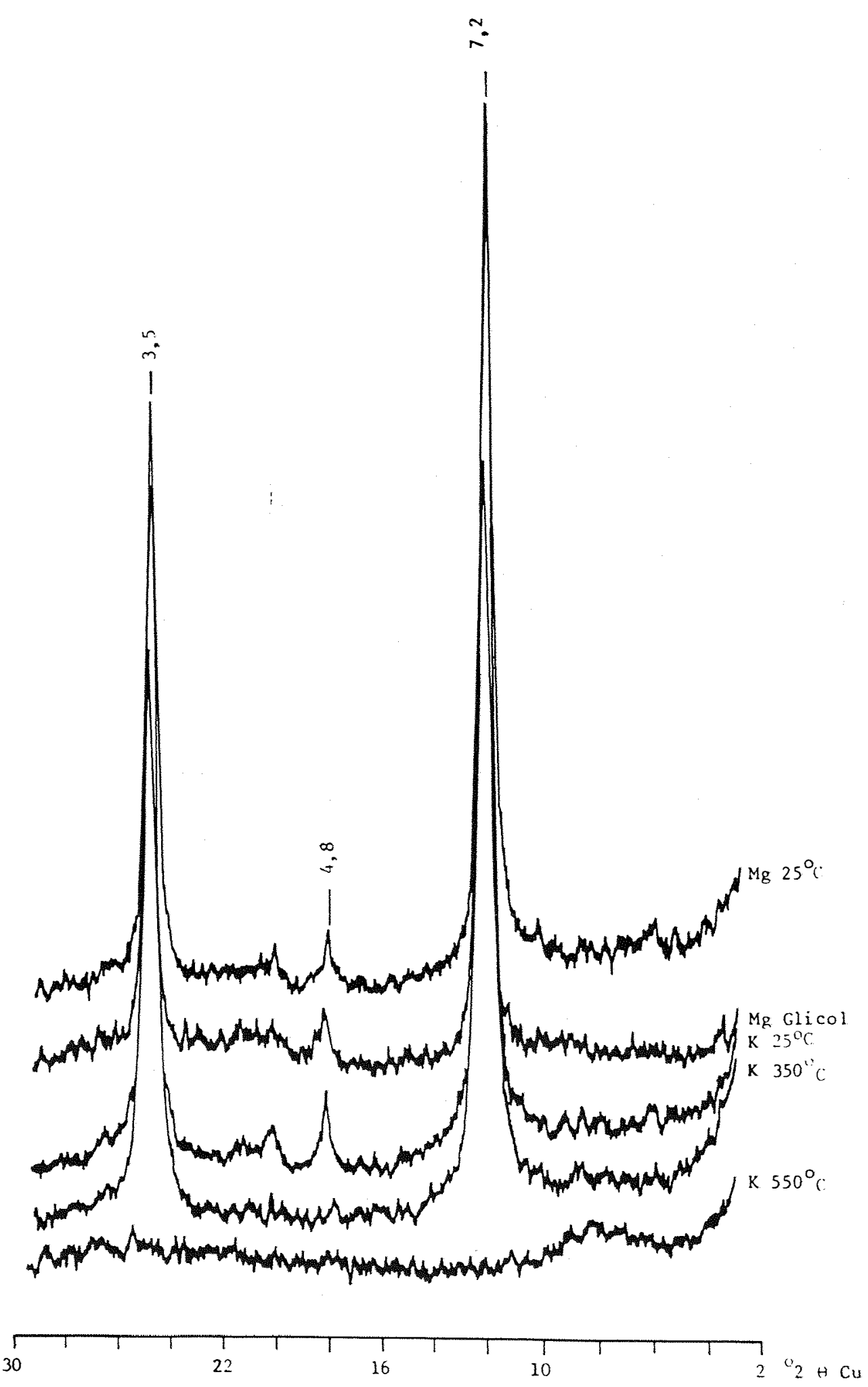

Difratogramas da fração argila do horizonte $\mathrm{BW}_{2}-\mathrm{LVp}$ (Perfil 2) 

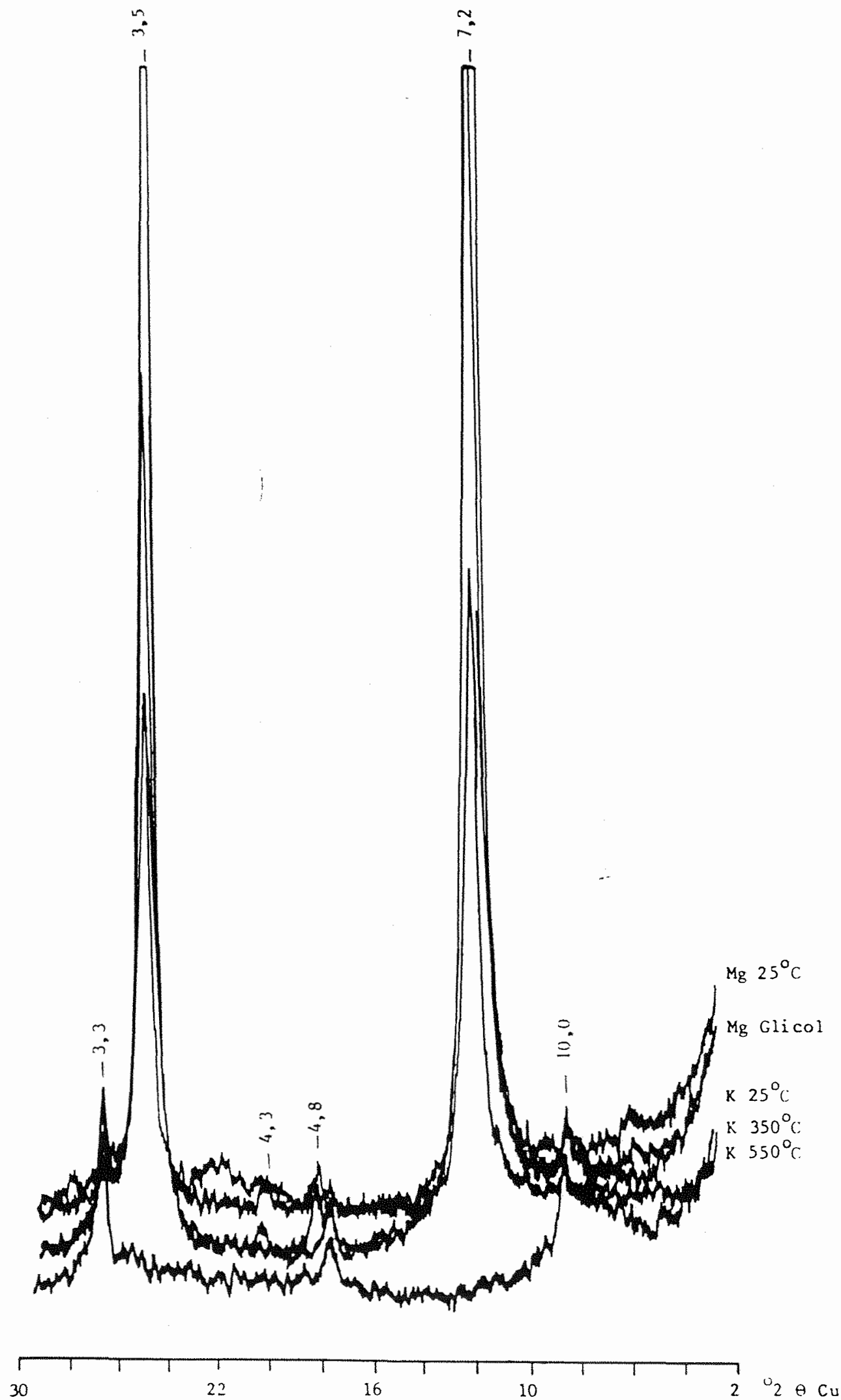

Difratogramas da fração argila do horizonte $A_{1}-P V_{2}$ (Perfil 3) 


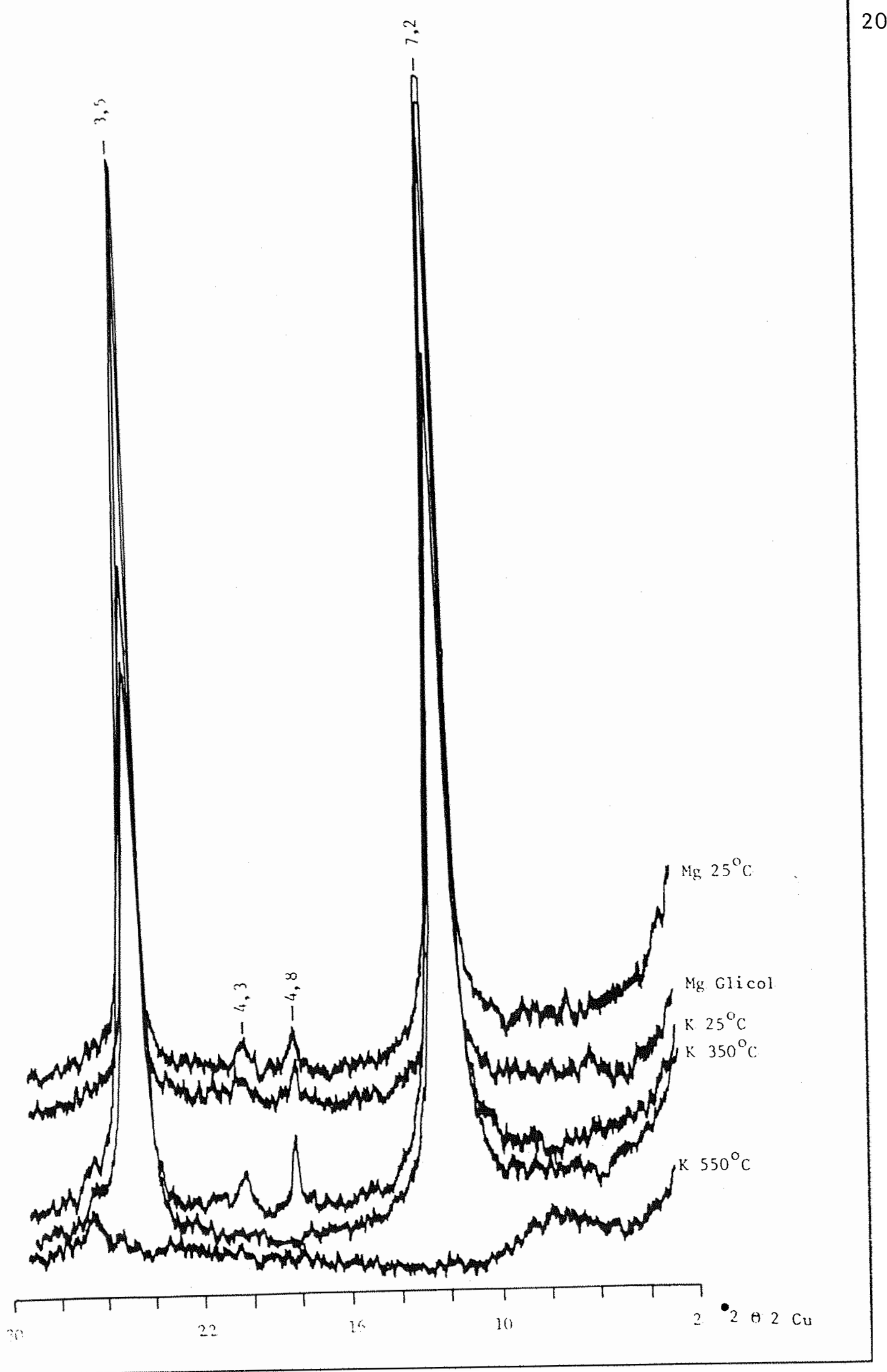

Jifratogramas da fração argila do horizonte $B t_{2}-P V_{2}$ (Perfil 3) 


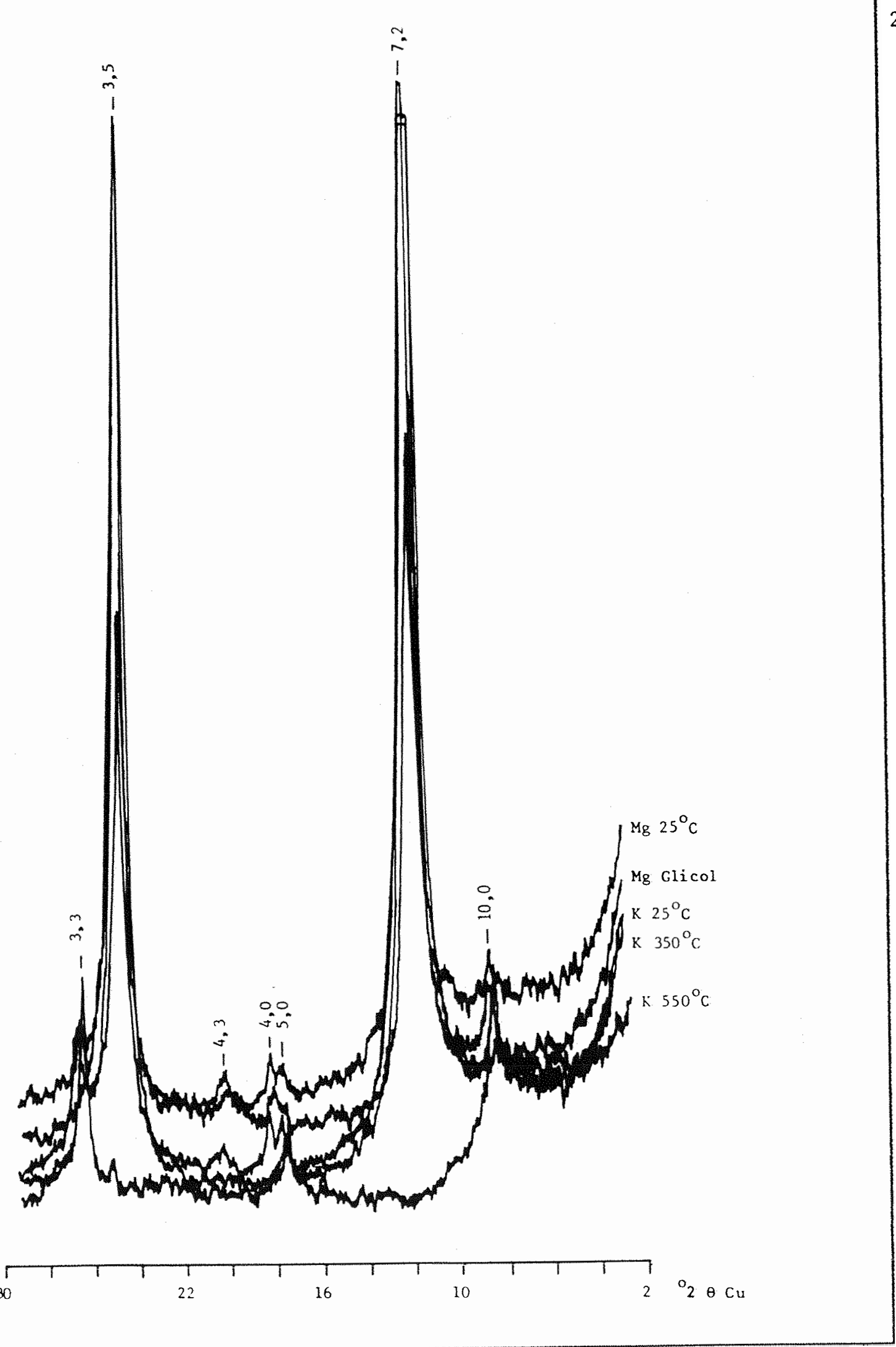

Difratogramas da fração argila do horizonte $A_{1}$ - PV3 (Perfil 4) 

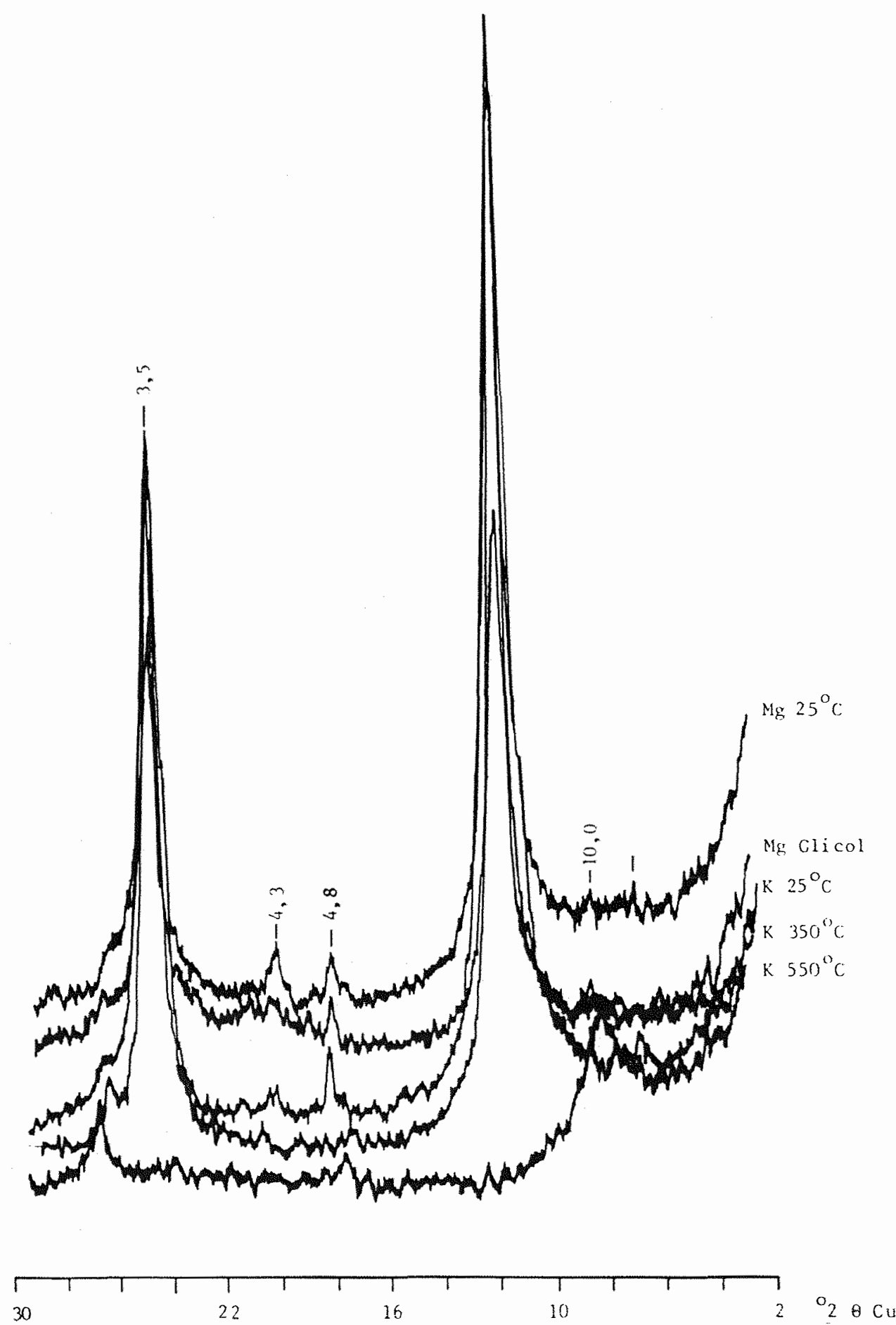

Difratogramas da fração argila do horizonte $B t_{2}-$ PV3 (Perfil 4) 

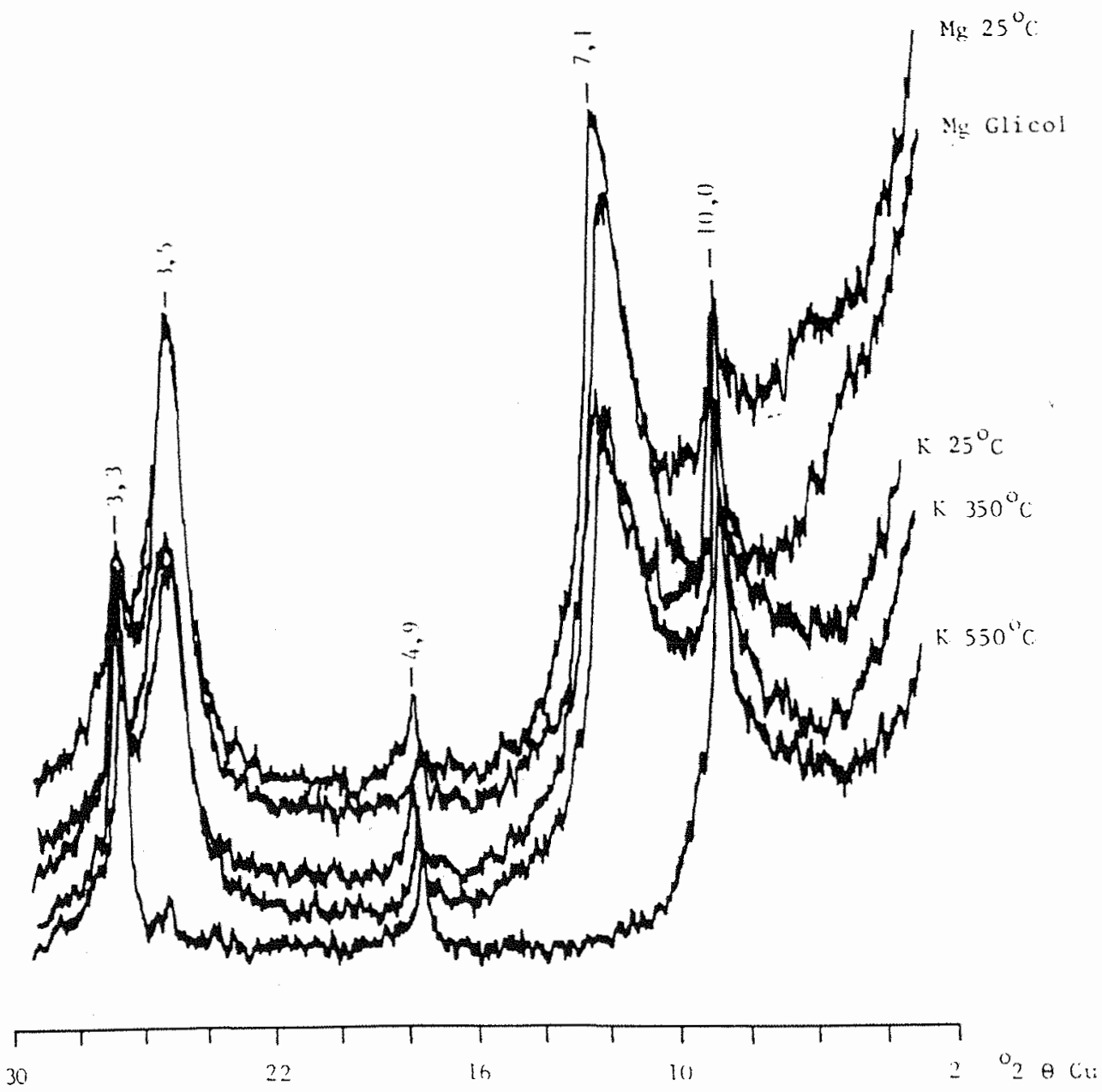

Difratogramas da fração argila do horizonte $A_{1}-$ PV4 (Perfil 5) 


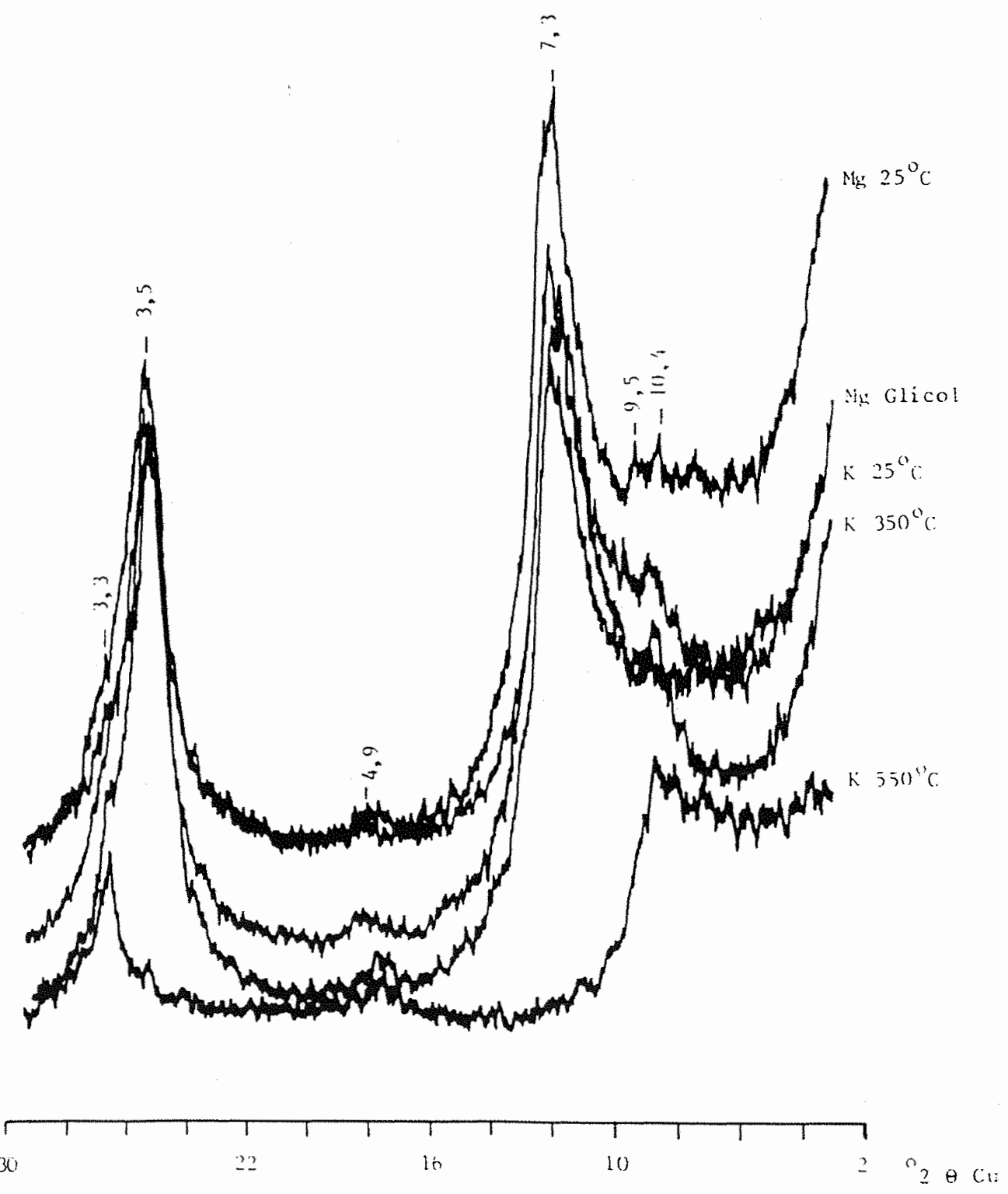

Difratogramas da fração argila do horizonte Bt2 - PV4 (Perfil 5) 


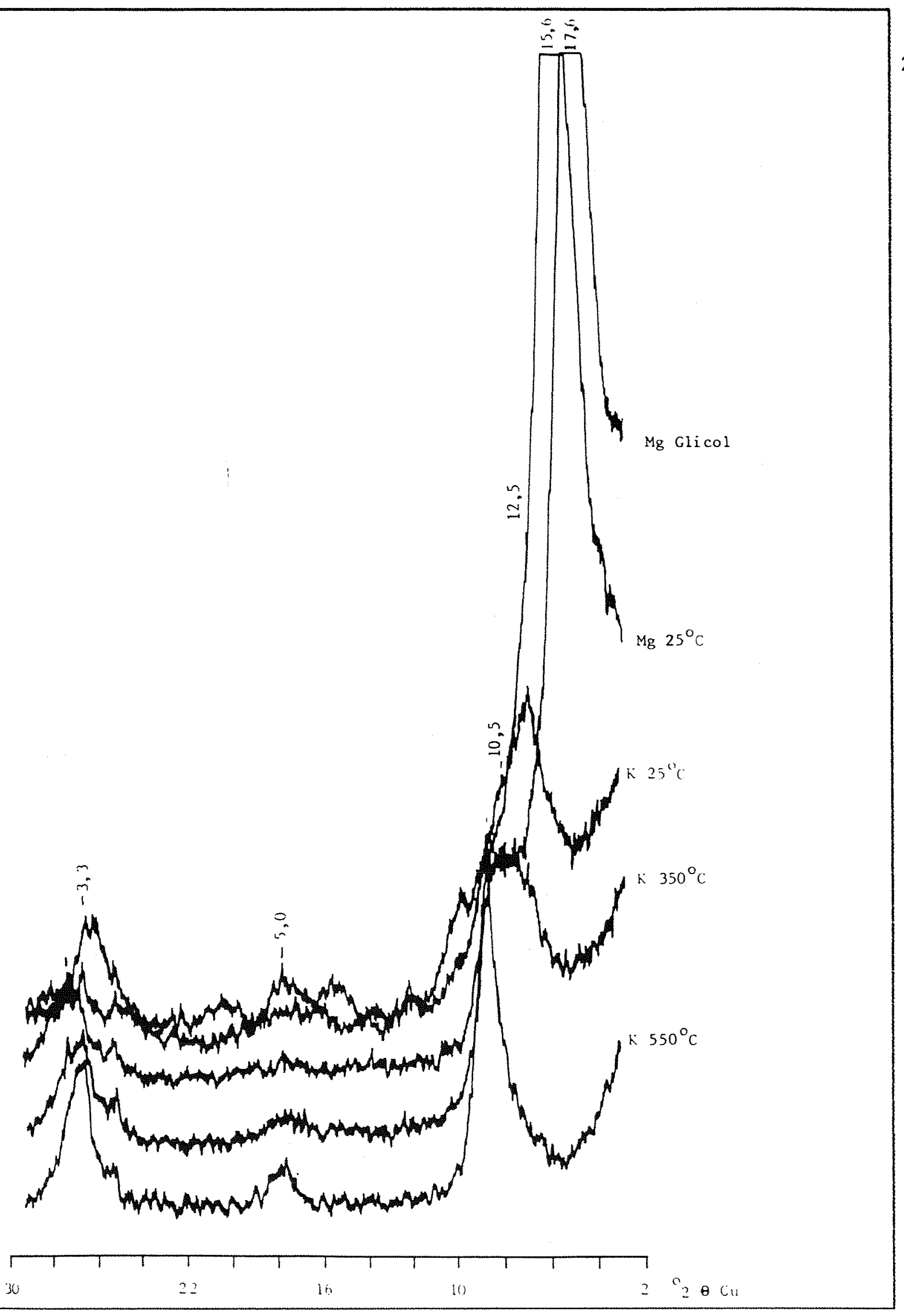




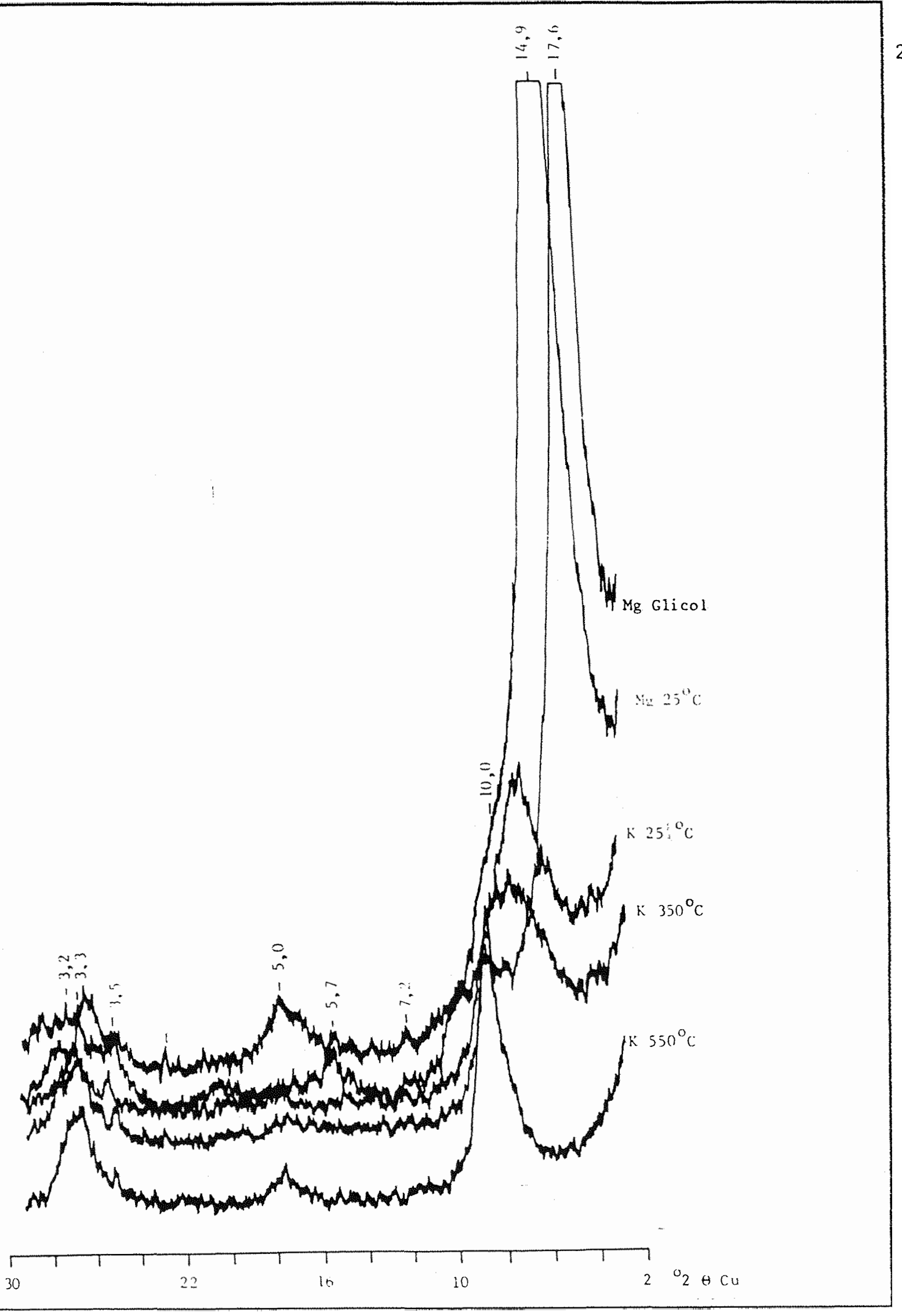




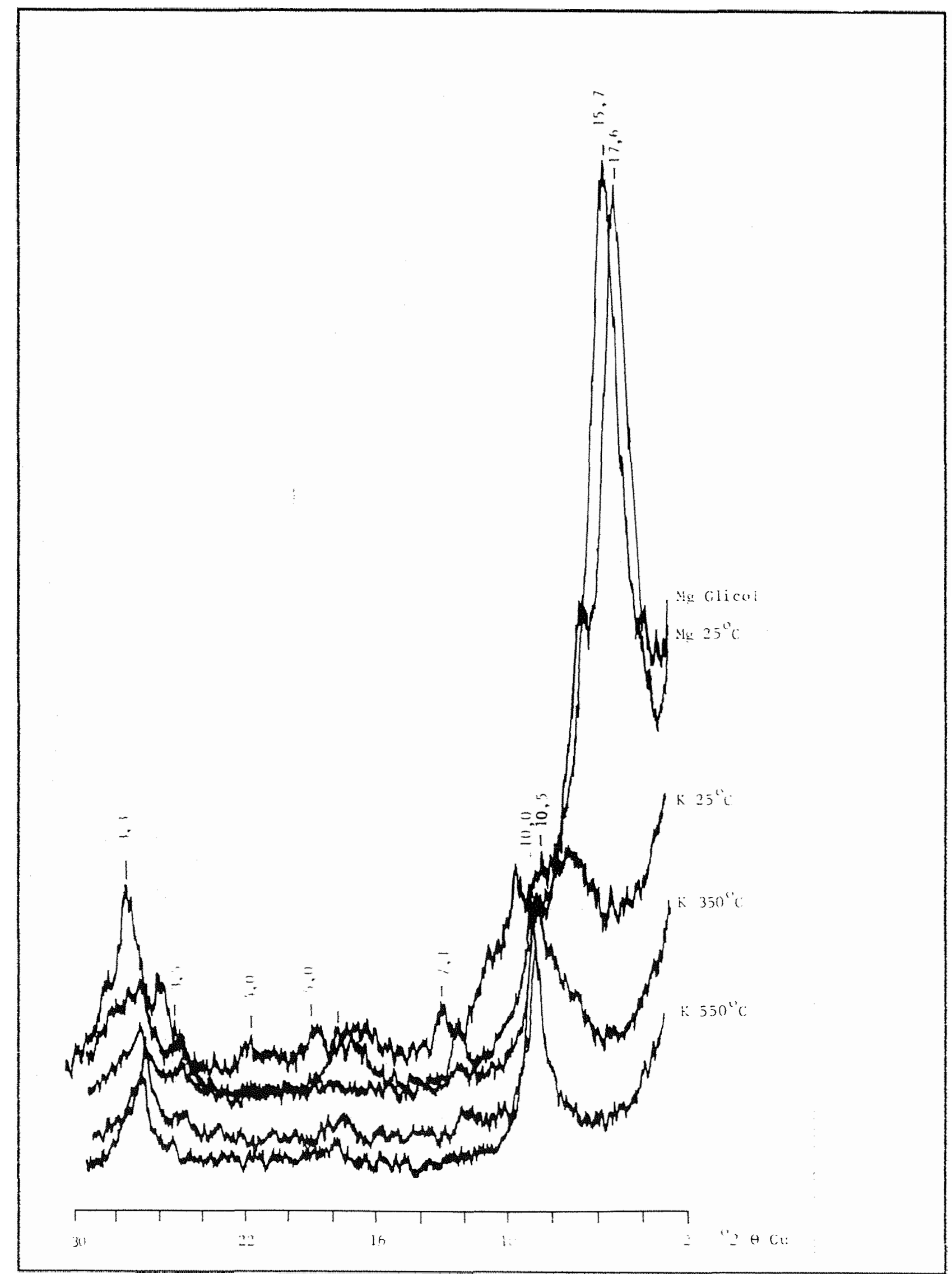

Difratogramas da fração argila do horizonte $A_{1}-B$ (Perfil 7) 


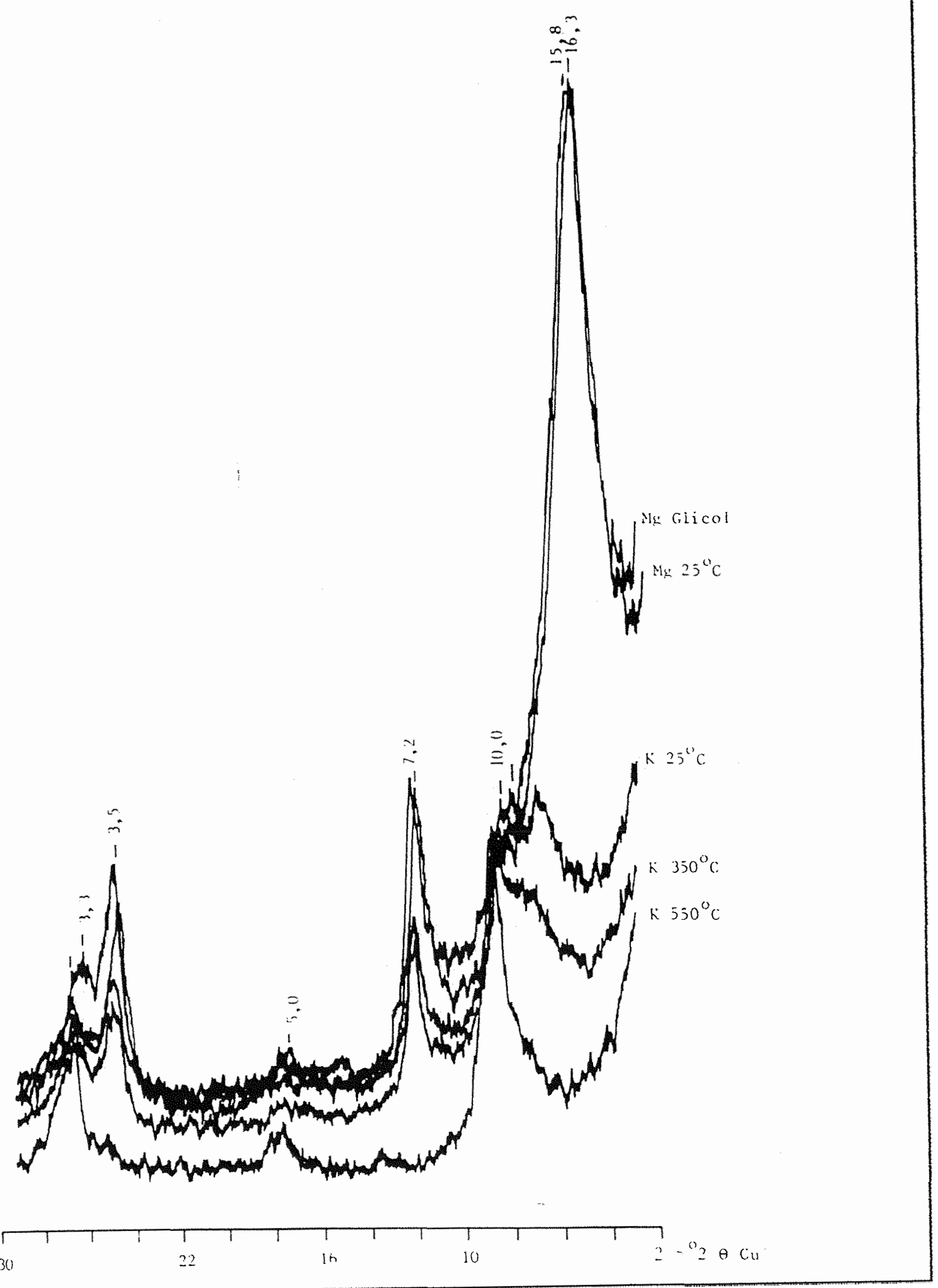

Difratogramas da fração argila do horizonte $B t_{2}-B$ (Perfil 7) 

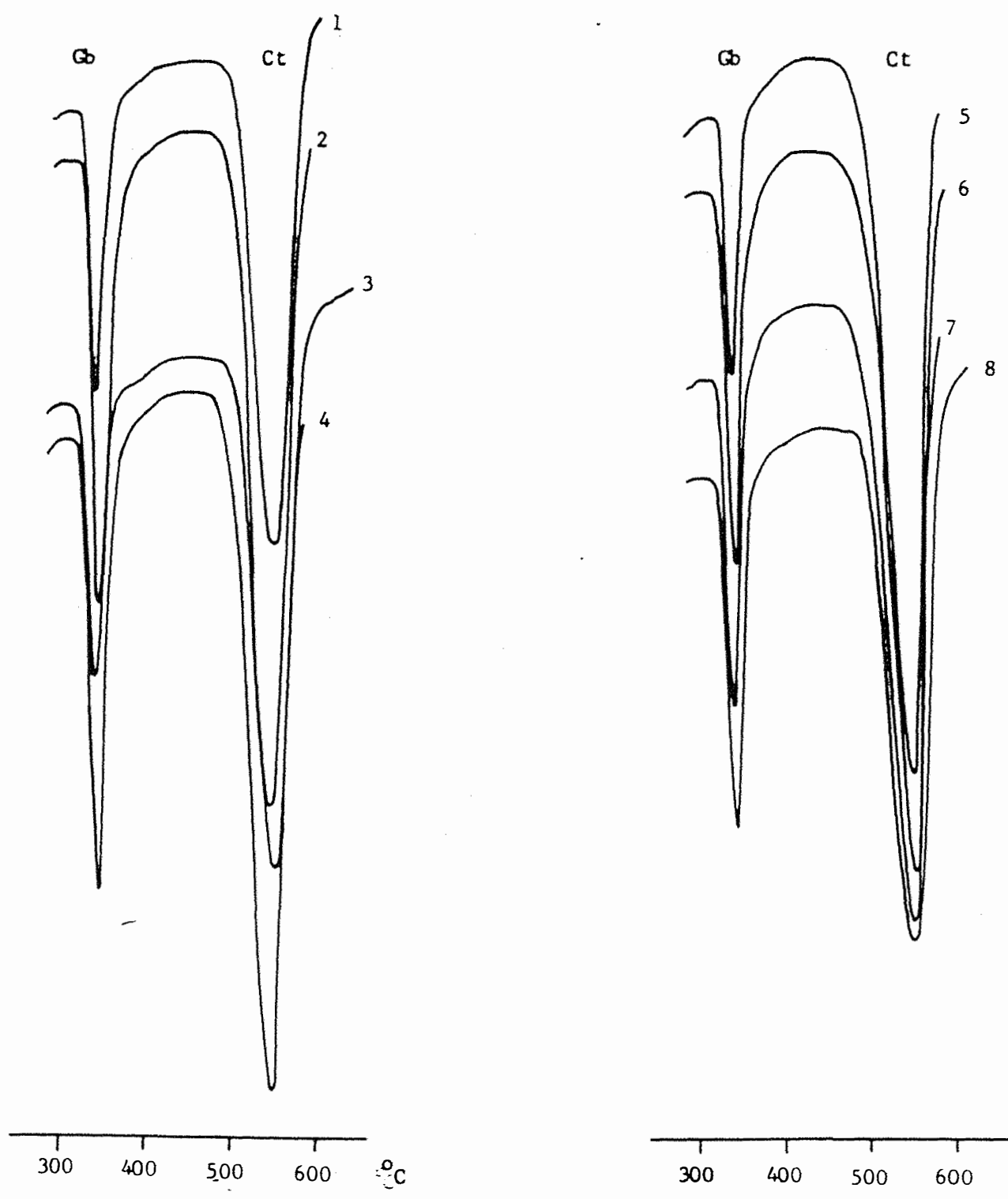

Curvas de anālise térmica diferencial (ATD), representativas da fração argila desferrificada dos solos.

$1=\operatorname{LVp}(\mathrm{Ap}) ; 2=\operatorname{LVp}(\mathrm{Bw} 1)(\operatorname{Perfil} 1) ; 3=\operatorname{LV}(\mathrm{A} 1) ; 4=\mathrm{LV}$ (Bw2) (Perfil

2) $; 5=\mathrm{PV}(\mathrm{Al}) ; 6=\mathrm{PV}(\mathrm{Bt2})(\operatorname{Perfil} 3) ; 7=\mathrm{PV}(\mathrm{Al}) ; 2=\mathrm{PV}(\mathrm{Bt} 2)(\operatorname{Per}-$ fil 4); $\mathrm{Gb}=$ gibbsita; $\mathrm{Ct}=$ caulinita. 

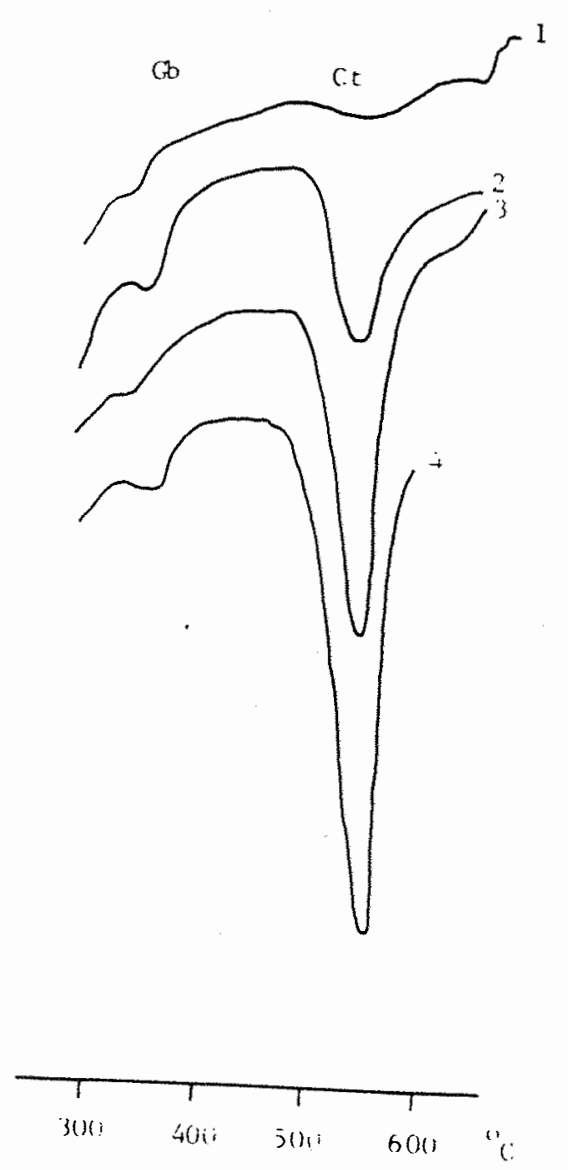

Curvas de anālise térmica diferencial (ATD), representativas da fração ar gila desferrificada dos solos.

$I=\mathrm{B} \quad(\mathrm{Al}) ; 2=\mathrm{B} \quad(\mathrm{Bt2})(\operatorname{Perfil} 7) ; 3=\mathrm{PV}(\mathrm{Al}) ; 4=\mathrm{PV}(\mathrm{Bt})$ (Perfil 5); $\mathrm{Gb}=$ gibbsita; $\mathrm{Ct}=$ caulinita. 


\section{A P E NDICE 6}

CARACTERÍSTICAS QUÍMICAS DO DEPÓSTIO NEO-CENOZÓICO OBTIDAS POR AMOSTRAGEM PROFUNDA 
Análise química da primeira amostragem profunda.

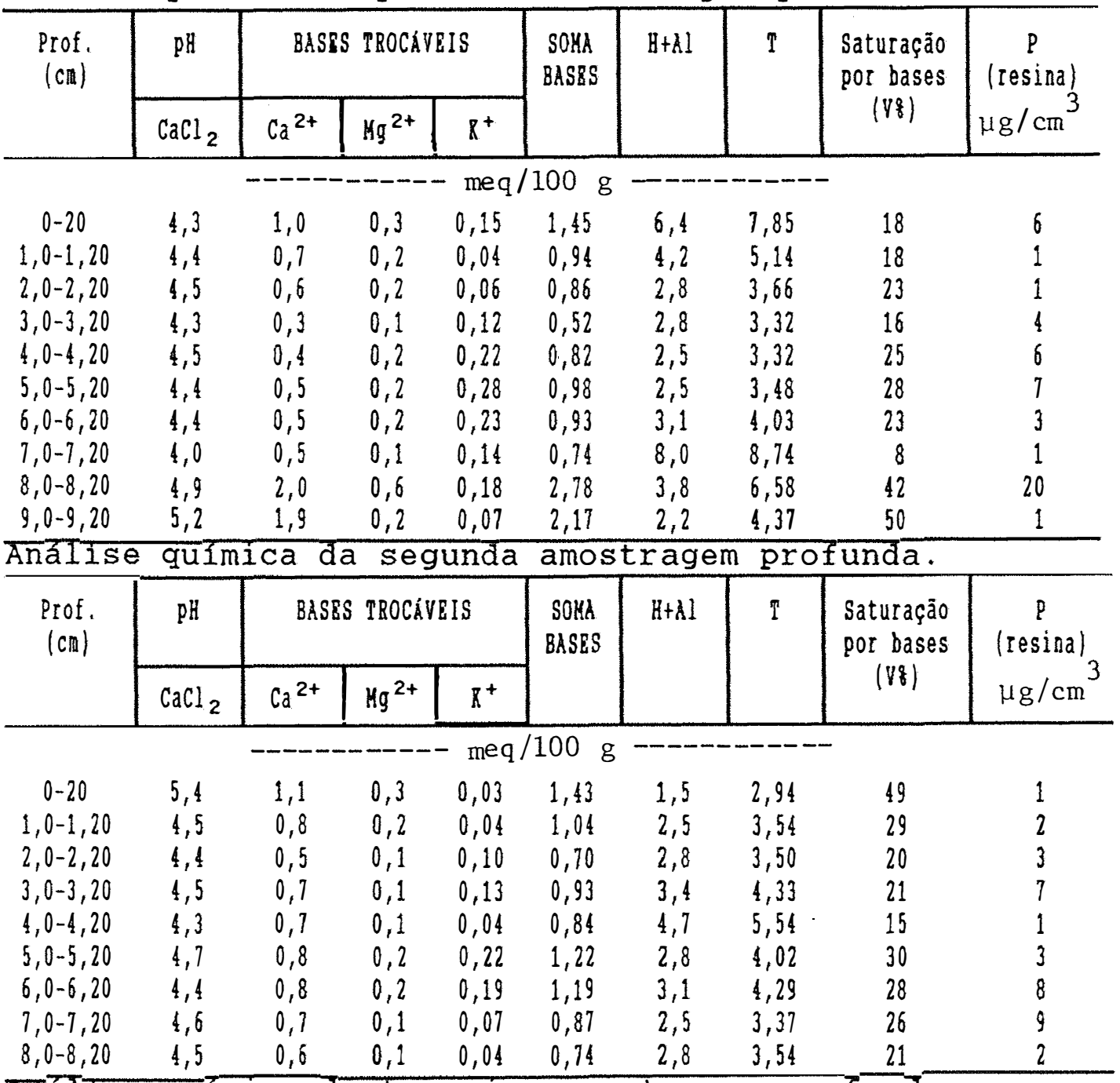

Analise quimica da terceira amostragem profunda.

\begin{tabular}{|c|c|c|c|c|c|c|c|c|c|}
\hline \multirow{2}{*}{$\begin{array}{l}\text { Prof. } \\
\text { (cII) }\end{array}$} & pH & \multicolumn{3}{|c|}{ BASES TROCAVEIS } & \multirow{2}{*}{$\begin{array}{l}\text { SOMA } \\
\text { BASES }\end{array}$} & \multirow[t]{2}{*}{$B+A I$} & \multirow[t]{2}{*}{9} & \multirow{2}{*}{$\begin{array}{c}\text { Saturação } \\
\text { por bases } \\
\text { (Vq) }\end{array}$} & \multirow{2}{*}{$\begin{array}{c}\mathrm{p} \\
\text { (resina) } \\
\mu \mathrm{g} / \mathrm{cm}^{3}\end{array}$} \\
\hline & $\mathrm{CaCl}_{2}$ & $\mathrm{Ca}^{2+}$ & $\mathrm{Mg}^{2+}$ & $R^{+}$ & & & & & \\
\hline & & & & & & & & & \\
\hline $0-20$ & 4,4 & 0,7 & 0,3 & 0,28 & 1,28 & 5,2 & 6,48 & 20 & 39 \\
\hline $1,0-1,20$ & 4,1 & 0,5 & 0,2 & 0,04 & 0,74 & 5,8 & 6,54 & 11 & 1 \\
\hline $2,0-2,20$ & 4,2 & 0,6 & 0,2 & 0,07 & 0,87 & 3,4 & 4,27 & 20 & 1 \\
\hline $3,0-3,20$ & 4,1 & 0,2 & 0,1 & 0,06 & 0,36 & 3,4 & 3,76 & 10 & 2 \\
\hline $4,0-4,20$ & 4,2 & 0,2 & 0,1 & 0,06 & 0,36 & 3,1 & 3,46 & 10 & 4 \\
\hline $5,0-5,20$ & 4,2 & 0,2 & 0,1 & 0,04 & 0,34 & 3,4 & 3,74 & 9 & $\delta$ \\
\hline $6,0-6,20$ & 4,0 & 0,2 & 0,1 & 0,04 & 0,34 & 3,8 & 4,14 & 8 & 8 \\
\hline $7,0-7,20$ & 4,1 & 0,2 & 0,1 & 0,06 & 0,36 & 4,2 & 4,54 & 8 & 4 \\
\hline $8,0-8,20$ & 4,0 & 0,3 & 0,1 & 0,09 & 0,69 & 12,1 & 12,59 & 4 & 1 \\
\hline $9,0-9,20$ & 4,0 & 0,4 & 0,1 & 0,12 & 0,82 & 12,3 & 14,12 & 4 & 1 \\
\hline
\end{tabular}


A P E N D I C E 7

CAPACIDADE DE TROCA DE CÁTIONS DA ARGILA DOS PERFIS DE SOLOS ESTUDADOS, PELO MÉTODO GRÁFICO 


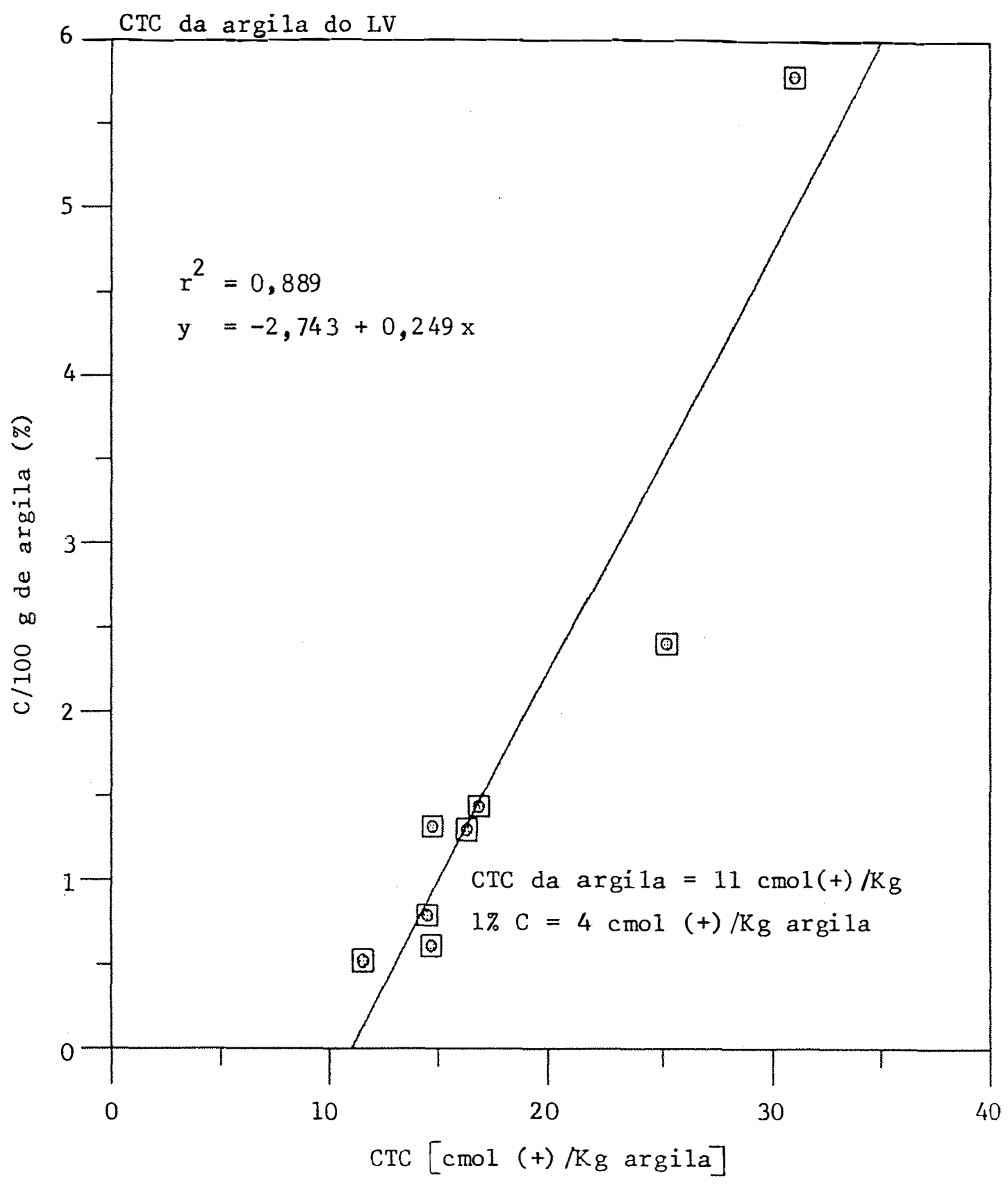




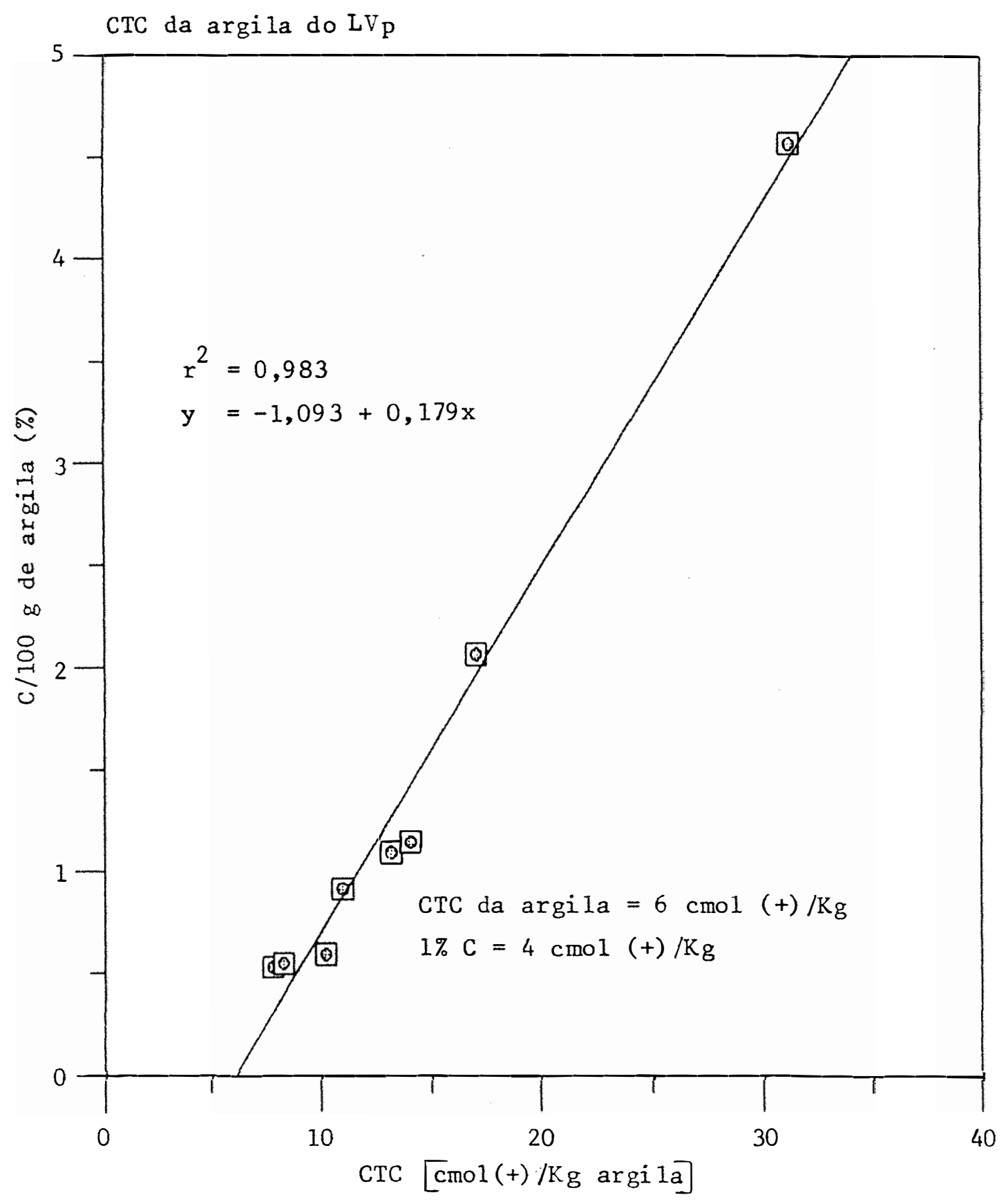




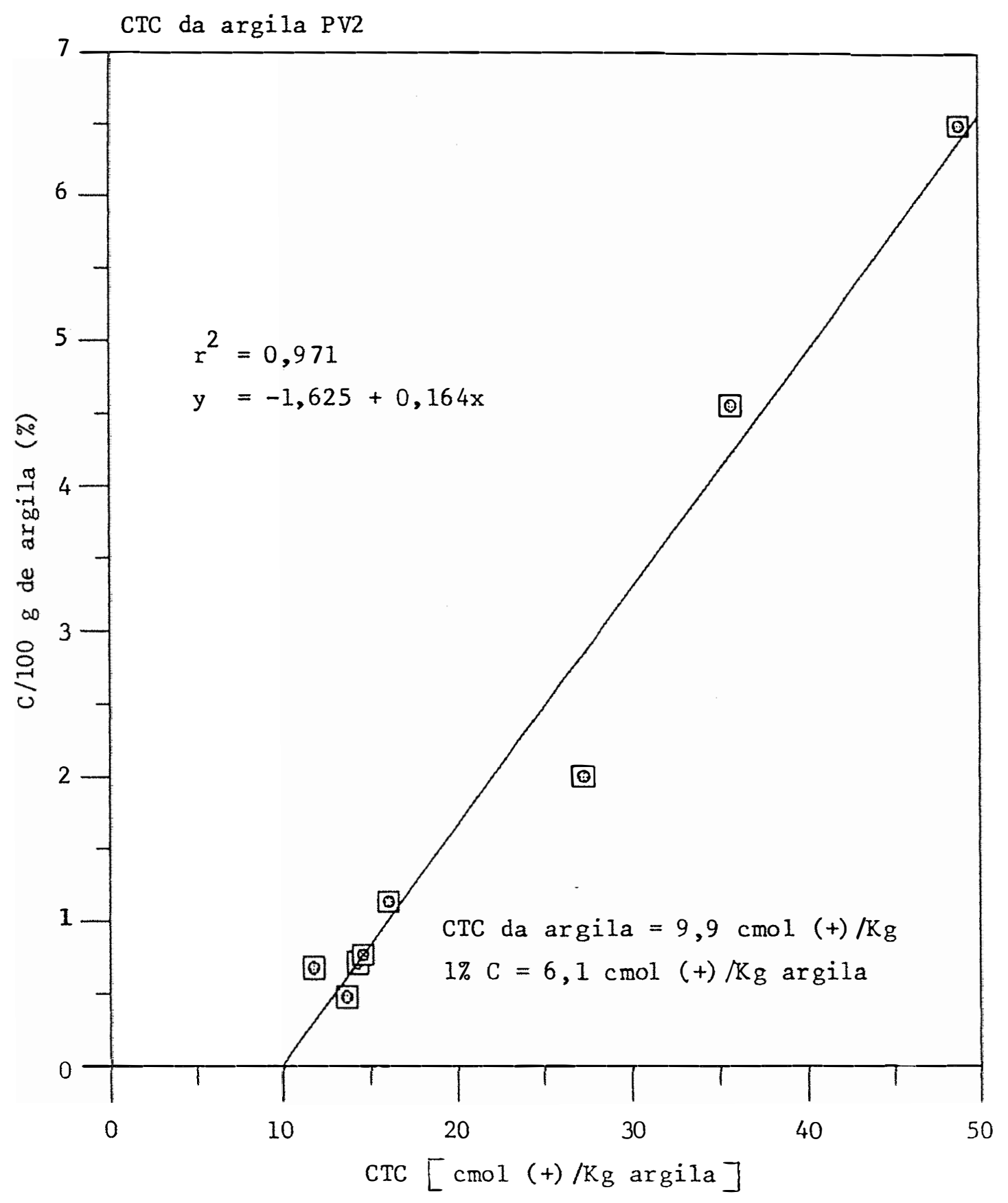




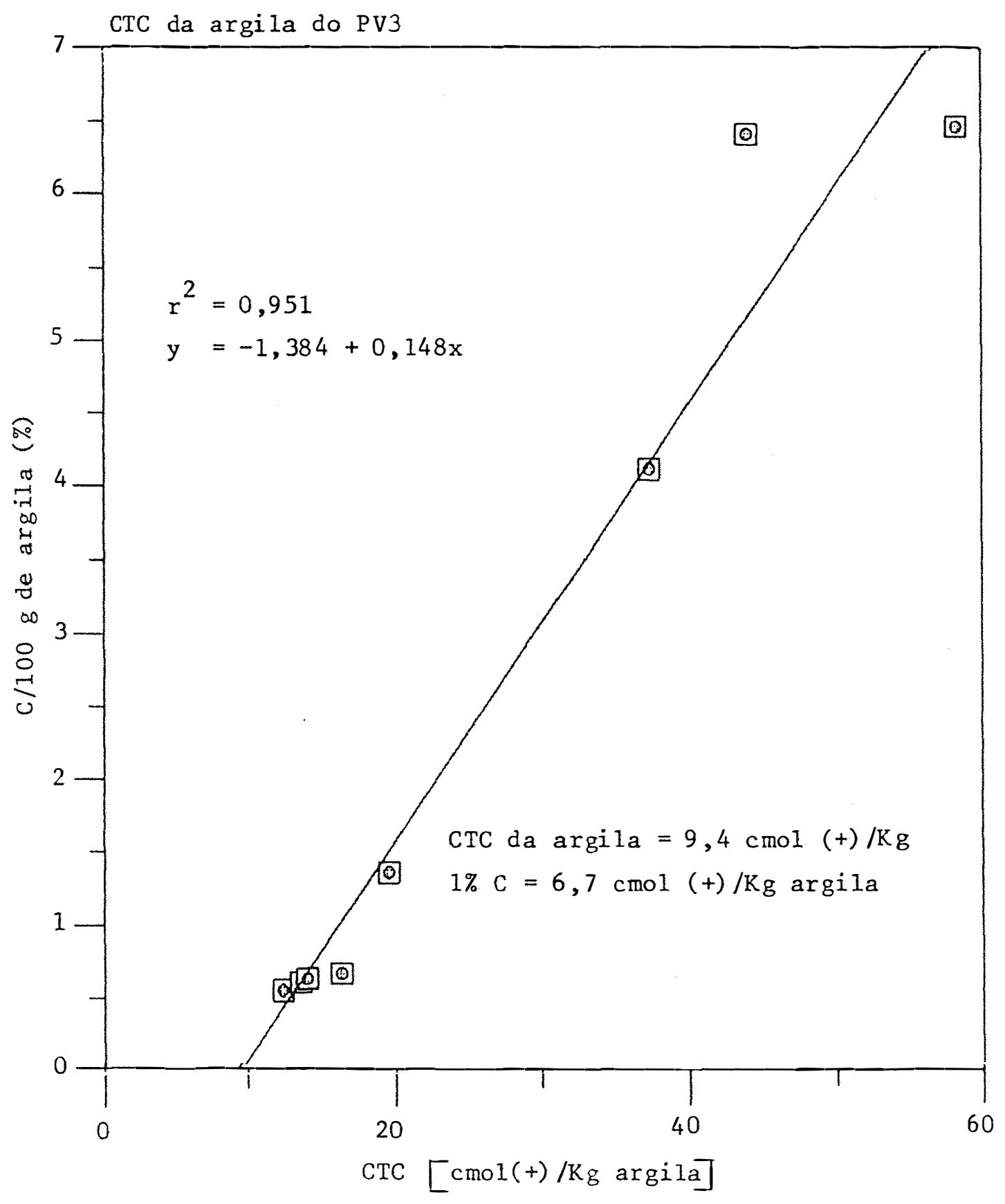




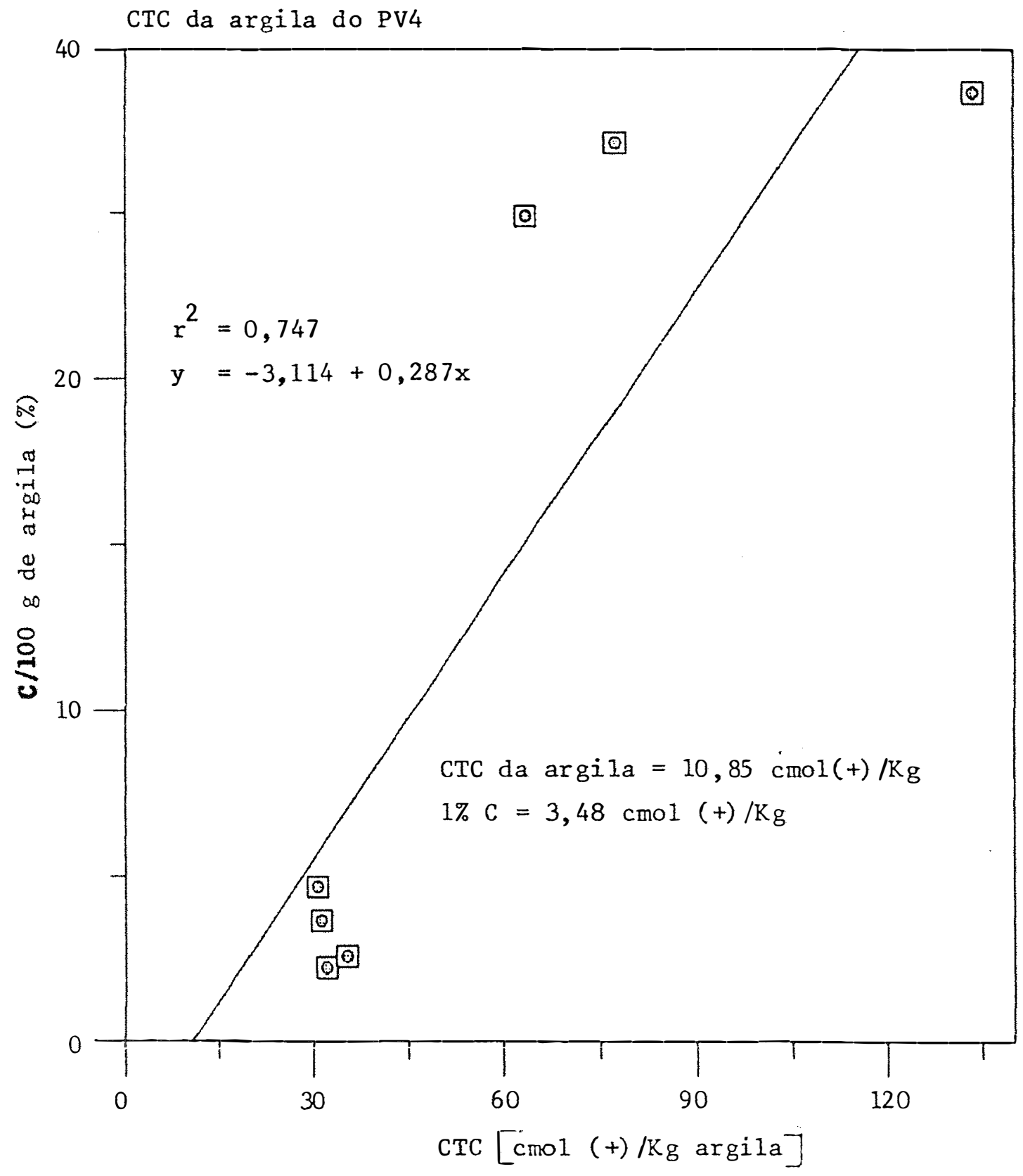




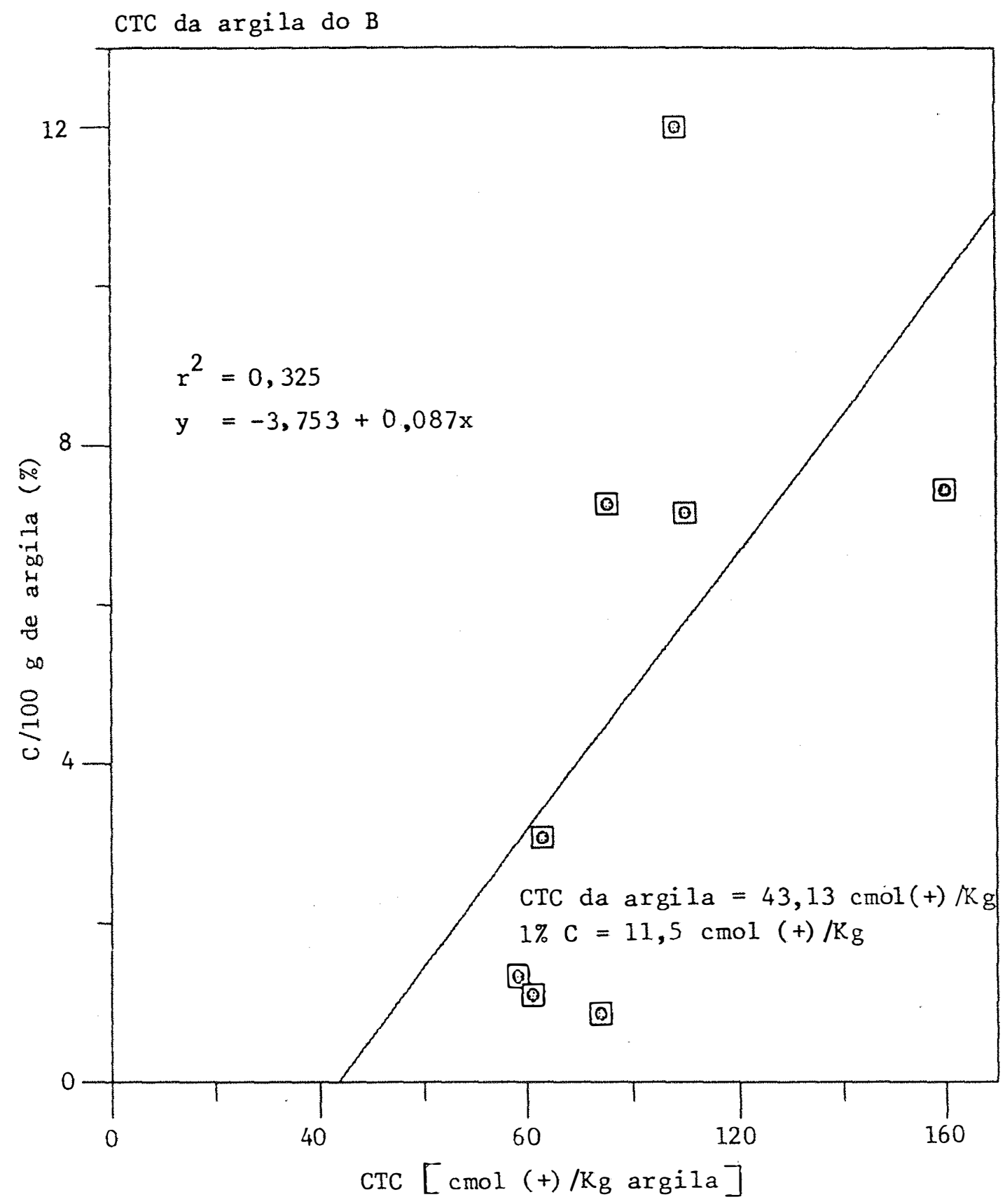

